\title{
PALAEOGEOGRAPHY OF A MID MIOCENE TURBIDITE COMPLEX, MOKI FORMATION, TARANAKI BASIN, NEW ZEALAND
}

Sarah Louise Grain

A thesis submitted for the partial fulfilment for the degree of Masters of Science with Honours in Petroleum Geoscience

School of Geography, Environment and Earth Sciences

Victoria University of Wellington

2008 


\section{Abstract}

The Moki Formation, Taranaki Basin, New Zealand, is a Mid Miocene (Late Altonian to Early Lillburnian) sand-rich turbidite complex bounded above and below by the massive bathyal mudstone of the Manganui Formation. The Moki Formation is a proven hydrocarbon reservoir with its stacked, thick, tabular sandstone packages totalling more than $300 \mathrm{~m}$ in places. Previous regional studies of the formation have been based primarily on well data and resulted in varying palaeogeographic interpretations. This study, restricted to the southern offshore region of the basin, better constrains the spatial and temporal development of the Moki Formation by combining well data with seismic interpretation to identify key stratal geometries within the sediment package.

Nearly 30,000 km of 2D seismic reflection profiles and two 3D surveys, along with data from 18 wells and three cores were reviewed and key sections analysed in detail. Seismic facies have been identified which provide significant insights into the structure, distribution and progressive development of the Moki Formation. These include: a clearly defined eastern limit of the fan complex, thinning and fining of the distal turbidite complex onto the basin floor in the north and west, evidence of fan lobe switching, spectacular meandering channel systems incised into the formation at seismic scales, and the coeval palaeoshelf-slope break in the south east of the basin. In addition, a Latest Lillburnian / Waiauan turbidite complex has been mapped with large feeder, fan and bypassing channels traced.

This study presents an improved palaeogeographic interpretation of the Moki Formation and the younger, Latest Lillburnian / Waiauan-aged, turbidite complex. This interpretation shows that during the Late Altonian, sandstone deposition was localised to small fan bodies in the vicinity of Maui-4 to Moki-1 wells. A bathymetric deepening during the Clifdenian is identified, which appears to have occurred concurrently as the establishment of the Moki Formation fan system, centred around the southern and central wells. With continued sediment supply to the basin floor, the fan system prograded markedly northward and spilled onto the Western Stable Platform during the early Lillburnian. Sand influx to the bathyal basin floor abruptly ceased and large volumes of mud were deposited. By the Waiauan stage, sands were again deposited at bathyal depths on fan bodies and carried to greater depths through a complex bypassing channel system. 


\section{Acknowledgements}

During the course of this thesis, a number of people have kindly provided their expertise, time and support. I apologise to anyone whom I may have missed.

Firstly, I would like to thank Peter King and Cliff Atkins for their supervision and encouragement of what proved to be a very interesting project, and their well-balanced reviews of this thesis. I will carry their positive influence with me throughout my career.

Secondly, I would like to thank numerous people at GNS Science, especially the Seismic Facies Mapping Team for their generosity of time, on-going discussion, advice and support. In particular, thanks to Malcolm Arnot for advice in seismic interpretation and general support; Lucia Roncaglia for generous help with the wireline log software and interpretation; Dominic Strogen for advice in the construction of palaeogeographic maps; Jan Baur for many thought-provoking discussions and advice; Hannah Bushe for help in seismic interpretation; Michael Massey, Mike Milner and Hai Zhu for providing data and help sorting out issues, Martin Crundwell and Hugh Morgans for palaeontological data.

Thanks to staff and students at Victoria University including Mike Hannah, Tim Naish, Lionel Carter, Peter Barrett, Tim Stern and John Collen for their interest, discussion and advice; Matt Stevens for helping with core descriptions; Dan Bassett for advice in drafting some of the figures; Andrew Kolodziej, Michael Gazley, Matt Stevens and Caroline Hall for help with editing, and Gillian Ruthven for library assistance. Thanks to all the postgraduate students for their support, positive encouragement and the needed breaks.

I would also like to thank staff formerly at Austral Pacific, in particular, Roger Brand, Carey Mills, Hamish Gordon and Beate Leitner for their invaluable suggestions, insightful discussions and advice; Neville Smith, Glen Thrasher, Mark Blood, Gabrielle Travers at Todd Energy for expressing their interest in my project and their valuable feedback; Mac Beggs and Kim Styles at Geosphere for their interest, and the teams at Exxon Mobil and Chevron who attended my presentations and provided useful comment and discussion.

Finally, I am grateful to my family for their constant encouragement and support, without which I would never have contemplated this undertaking. 


\section{Table of Contents}

ABSTRACT

ACKNOWLEDGEMENTS

III

TABLE OF CONTENTS IV

LIST OF FIGURES

VI

LIST OF TABLES

VIII

\subsection{INTRODUCTION} 1

1.1 GENERAL INTRODUCTION 1

1.2 PREVIOUS KNOWLEDGE OF THE MOKI FORMATION 1

1.3 STUDY AREA 2

1.4 Project Aims AND OUtLine $\quad 4$

$\underline{2.0}$ BACKGROUND GEOLOGY

2.1 TARANAKI BASIN 5

2.2 SUB-MARINE FANS AND TURBIDITE COMPLEXES

$\begin{array}{lll}2.3 & \text { MOKI FORMATION } & 18\end{array}$

$\begin{array}{lll}2.4 & \text { SUMMARY } & 24\end{array}$

3.0 REGIONAL SEISMIC INTERPRETATION

3.1 INTRODUCTION 25

3.2 DATA 25

3.3 INTERPRETATION METHODS

3.4 INTERPRETED HORIZONS 28

3.5 RESULTS AND DISCUSSION

3.6 SUMMARY 38

4.0 SEISMIC FACIES INTERPRETATION

$\begin{array}{lll}4.1 & \text { INTRODUCTION } & 39\end{array}$ 
4.2 PRINCIPLES OF SEISMIC SEQUENCE AND FACIES ANALYSIS 39

4.3 MID MIOCENE SEISMIC FACIES

4.4 SUMMARY 59

$\underline{5.0}$ WIRELINE LOGS $\quad 60$

5.1 INTRODUCTION

5.2 OVERVIEW OF WIRELINE LOGS

5.3 Wells

5.4 WeLl CORRELATIONS

$\begin{array}{lll}5.5 & \text { SUMMARY } & 78\end{array}$

6.0 CORE FACIES $\quad 79$

6.1 INTRODUCTION

6.2 LithOFACIES

6.3 FACIES ASSOCIATIONS

6.4 INTERPRETATION

$\begin{array}{lll}\text { 6.5 SUMMARY } & 90\end{array}$

$\underline{7.0}$ PALAEOGEOGRAPHY AND SYNTHESIS $\quad 91$

$\begin{array}{lll}7.1 & \text { INTRODUCTION } & 91\end{array}$

$\begin{array}{lll}7.2 & \text { INPUTS } & 91\end{array}$

$\begin{array}{llr}7.3 & \text { RESULTS AND DISCUSSION } & 94\end{array}$

$\begin{array}{lll}7.4 & \text { SUMMARY } & 104\end{array}$

$\underline{\text { 8.0 }}$ CONCLUSIONS 105

8.1 Project ACHIEVEMENTS 105

8.2 GEOLOGICAL HISTORY 105

8.3 IMPLICATIONS FOR HYDROCARBON PROSPECTIVITY 106

$\begin{array}{lll}8.4 & \text { FUTURE WORK } & 107\end{array}$

REFERENCES $\quad 108$

APPENDIX A NEW ZEALAND NEOGENE TIMESCALE

$\underline{\text { APPENDIX B }}$ RELATED PETROLEUM AND BIOSTRATIGRAPHY REPORTS 120 
A) General Well Data

B) VELOCITY CURVES

C) REVISED FORMATION TOPS $\quad 138$

APPENDIX E WELL SHEETS

$\underline{\text { APPENDIX F }}$ CORE DESCRIPTION SHEETS $\quad 166$

\section{List of figures}

Figure $1.1 \quad$ Study area locality map

$\begin{array}{lll}\text { Figure 2.1 Tectonic and structural setting } & 6\end{array}$

Figure 2.2 Chronostratigraphic panel of generalised Taranaki Basin stratigraphy 7

Figure 2.3 Various palaeogeographic maps of Taranaki Basin 9

$\begin{array}{lll}\text { Figure 2.4 Generalised structure of a turbidity current } & 14\end{array}$

$\begin{array}{lll}\text { Figure 2.5 } & \text { Bouma (1962) generalised turbidite deposit } & 14\end{array}$

Figure 2.6 Normark (1970) sub-marine fan model 16

Figure 2.7 End member submarine fans of different sediment type 17

Figure 2.8 De Bock (1994) Moki Formation palaeogeography 21

Figure 2.9 King and Thrasher (1996) Mid Miocene palaeogeography 22

Figure 3.1 Map of seismic line locations 26

Figure 3.2 Seismic line ct95-12 showing Moki Formation seismic character 29

Figure 3.3 Seismic line 86ma-103 showing S1/Sw Sandston seismic character 30

Figure 3.4 Top Moki Formation TWTT structure map 32

Figure 3.5 Seismic line tnz81-618 showing offset across the Cape Egmont Fault 33

Figure 3.6 Composite regional seismic line NS-1 35

Figure 3.7 Composite regional seismic line EW-2 36

$\begin{array}{lll}\text { Figure } 3.8 & \text { Moki Formation two-way travel-time isopach map } & 37\end{array}$

Figure 4.1 Types of seismic reflector terminations 40

Figure 4.2 Configuration of typical reflection patterns 41 
Figure 4.3 Seismic lines or03-005 and ds2-82-13 showing Mid Miocene clinoforms43

Figure 4.4 Seismic line s89-05 showing clinoforms intersected by Motueka-1 44

Figure 4.5 Seismic line hzta82a-112 showing eastern limit of Moki Formation 46

Figure 4.6 Seismic lines stos95-300 and stos95-108 showing channel incisions 48

Figure 4.7 Schematic diagram explaining channel isopachs 49

Figure 4.8 Isopach map between channels and top Sl/Sw Sandstone horizon $\quad 50$

Figure 4.9 Composite RMS amplitude map of S1/Sw Sandstone channels 52

Figure 4.10 Maui-3D semblance stratal slice showing Moki Formation channels 55

Figure 4.11 Maui-3D semblance stratal slice showing Sl/Sw Sandstone channels 56

Figure 4.12 Composite E-W seismic line showing thinning of Moki Formation 58

Figure 5.1 Location map of wells used for wireline log analysis 61

$\begin{array}{lll}\text { Figure 5.2 Typical gamma ray curve motifs } & 67\end{array}$

$\begin{array}{lll}\text { Figure 5.3 Motueka-1 gamma ray log } & 68\end{array}$

$\begin{array}{lll}\text { Figure 5.4 Tasman-1 gamma ray log } & 68\end{array}$

$\begin{array}{lll}\text { Figure 5.5 Moki-1 gamma ray log } & 70\end{array}$

$\begin{array}{lll}\text { Figure 5.6 Te Whatu-2 gamma ray log } & 70\end{array}$

$\begin{array}{lll}\text { Figure } 5.7 & \text { Well Correlation } 1 & 75\end{array}$

$\begin{array}{lll}\text { Figure 5.8 Well Correlation } 2 & 76\end{array}$

$\begin{array}{lll}\text { Figure 5.9 Well Correlation } 3 & 77\end{array}$

$\begin{array}{lll}\text { Figure 6.1 Moki Formation core study well locations } & 79\end{array}$

Figure 6.2 Examples of massive sandstone facies 82

Figure 6.3 Examples of fining-up, laminated sandstone facies 83

Figure 6.4 Examples of finely interbedded mudstone and sandstone facies $\quad 84$

Figure 6.5 Examples of massive mudstone $\quad 84$

Figure 6.6 Examples of mottled mudstone $\quad 85$

Figure 6.7 Typical fining-up facies association 86

Figure 6.8 Intercollated massive sandstone and mottled mudstone facies $\quad 87$

$\begin{array}{lll}\text { Figure } 6.9 & \text { Core exhibiting evidence of channelisation } & 87\end{array}$

Figure 7.1 Legend for figures in Chapter 7 95

Figure 7.2 South-north chronostratigraphic panel 95

$\begin{array}{lll}\text { Figure 7.2 Late Altonian palaeogeography map } & 98\end{array}$

Figure 7.3 Clifdenian palaeogeography map 99

$\begin{array}{lll}\text { Figure 7.4 Early Lillburnian palaeogeography map } & 100\end{array}$ 
Figure 7.5 Waiauan palaeogeography map

\section{List of tables}

Table 2.1 Summary of deep-water density flows

Table 5.1 Summary of wireline logs $\quad 62$

$\begin{array}{lll}\text { Table 5.2 Revised formation tops } & 65\end{array}$

$\begin{array}{lll}\text { Table 6.1 Moki Formation core facies summary } & 81\end{array}$

Table 7.1 Summary of foraminiferal palaeobathymetry 93 


\subsection{Introduction}

\subsection{General introduction}

The Moki Formation is a Mid Miocene turbidite complex in the Taranaki Basin, western North Island, New Zealand (Figure 1.1). During the Miocene, regional tectonics uplifted the hinterland to the south and east of the basin, permitting large volumes of rock to be exposed, eroded and transported to bathyal depths. This sediment formed the thick turbidite complex of the Moki Formation (e.g. King and Thrasher, 1996).

Turbidite complexes are of increasing interest to the oil and gas industry around the world for their hydrocarbon reservoir potential, as the more obvious structural traps are being exhausted. Individual turbidite sandstones are typically thick (3-20 m), may be continuous over hundreds of metres, are well-sorted and, therefore, provide good potential reservoirs while the interbedded, impermeable mudstones make good hydrocarbon seals. Thus, the intercalated relationship of the sandstones and mudstones of turbidite complexes provide excellent stratigraphic trapping opportunities (e.g. Walker, 1978).

The Taranaki Basin is New Zealand's only hydrocarbon producing basin, with some 340 million barrels (mmbbl) of oil and 4530 billion cubic feet (bcf) of gas produced from 1970 to 2007 (Crown Minerals, 2008). Historically, the Moki Formation has been a secondary target after significant discoveries were made in Eocene-aged sandstones (e.g. Kapuni Field; Maui Field). However, good hydrocarbon shows in the Moki Formation have been documented in numerous wells and the formation provides the reservoir for the Maari field currently under development (e.g. Rogers et al., 2000; Hounsell, 2006).

This thesis investigates the regional depositional system and palaeogeography of the Moki Formation within the southern offshore region of the Taranaki Basin, drawing on seismic interpretation, wireline logs and core information.

\subsection{Previous knowledge of the Moki Formation}

Previous studies of the Moki Formation have generally focussed on its hydrocarbon potential over permit or prospect-sized areas (e.g. Bussell, 1994; Dauzacker et al., 1996; Rogers et al., 2000; Engbers, 2002). Regional interpretations (e.g. Lock, 1985; de Bock, 1994; King and Thrasher, 1996) have primarily used well data and have resulted in 
differing fan system interpretations. Whilst these interpretations agree in principle, the detail of the Moki Formation depositional system is not well understood. Therefore, further information from seismic profiles is required to better constrain the fan system between well locations.

Open-file seismic data (held by Ministry of Economic Development) over the southern offshore region of the basin is now of sufficient extent, density and quality, that combined with data from several recently drilled wells a detailed seismic interpretation is possible. GNS Science, a Crown Research Institute, is currently undertaking a five-year, basin-wide seismic facies mapping (SFM) project to create a digital atlas of structure and seismic stratigraphy. During 2008, the focus of the project was on the central-southern offshore region of the basin. This thesis contributes to the SFM project by providing a detailed study of the mid-Miocene stratigraphy and palaeogeography in the southern Taranaki Basin.

\subsection{Study area}

The study area of this research project is restricted to the southern offshore region of Taranaki Basin as shown in the grey shaded area in Figure 1.1. The Moki Formation is present in several areas of the Taranaki Basin as non-overlapping turbidite systems with the largest fan system over the southern offshore region, as interpreted by King and Thrasher (1996). This study area was chosen over other regions for several reasons:

1. the SFM project focused its interpretation over a similar area in 2008 (orange box in Figure 1.1);

2. this region includes the type-Moki section (in Moki-1; Lock, 1985);

3. sufficient wells have intersected the Moki Formation in this region;

4. there is good seismic coverage which is generally of good quality, and

5. the Moki Formation is a productive reservoir in the Maari field (currently under development for completion in early 2009; Leeb, 2008) and is therefore topical for the oil industry. 


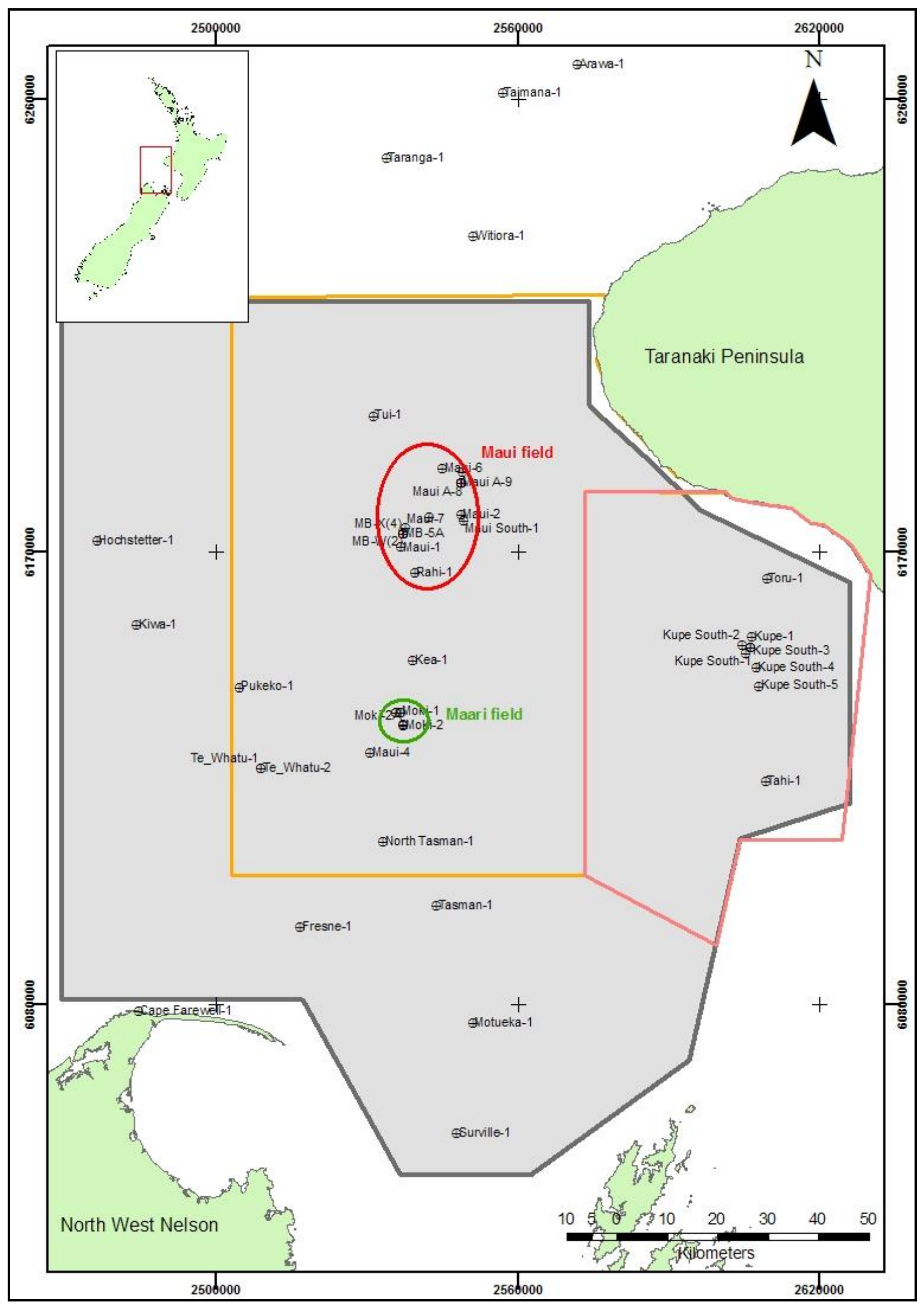

Figure 1.1: $\quad$ Map of the southern offshore region of the Taranaki Basin between North West Nelson and Taranaki Peninsula. The study area is shown in the grey shaded polygon. The pink and orange areas are the Kupe (completed) and Central (on-going) regions of the seismic facies mapping (SFM) project respectively (Arnot et al., 2008). Locations of the open-file wells and the Maari and Maui fields are shown. 


\subsection{Project aims and outline}

The aim of this project was to investigate the spatial and temporal development of the Moki Formation fan system in the southern offshore region of Taranaki Basin. This was achieved through regional seismic interpretation, identification of seismic facies, wireline $\log$ analysis and correlation, and core analysis.

Tied and phase-matched, open-file 2D and 3D seismic data and well information was provided by the GNS Science SFM project. Interpretation of several Mid Miocene reflectors (top Lillburnian-Waiauan aged Sandstone, top and base Moki Formation) on five regional composite seismic lines and subsequent in-fill lines, led to the creation of Two Way Travel Time (TWTT) structure maps and isopach maps (Chapter 3). Identification, description and mapping of seismic facies provided key constraints for the development of palaeogeographic maps and information on the processes and development of the Moki fan system (Chapter 4). These were then tested with analysis and correlation of wireline logs and biostratigraphic data from key wells (Chapter 5). Core facies were analysed to provide information on the Moki Formation at much greater detail (Chapter 6). This information was then combined and presented as revised palaeogeographic interpretations for the Mid Miocene (Chapter 7). 


\subsection{Background Geology}

\subsection{Taranaki Basin}

The Taranaki Basin is situated along the western margin of the New Zealand landmass on the Australian Plate behind a convergent margin to the east. Here, the Pacific Plate is subducting westward beneath the Australian Plate at a rate of $\sim 40 \mathrm{~mm}$ to its present depth of $\sim 150$ to $250 \mathrm{~km}$ beneath Taranaki Basin (Figure 2.1; Adams and Ware, 1977; Walcott, 1978; deMets et al., 1994). The nature of New Zealand's tectonic setting has changed substantially over the last 100 million years (King et al., 1999; King 2000a) including episodes of rifting, passive margin and convergence. These changes in plate margin evolution have controlled the geometry, subsequent infill and petroleum systems of New Zealand's sedimentary basins, including the Taranaki Basin.

The Taranaki Basin contains a thick (up to $9 \mathrm{~km}$ ) sequence of Cretaceous to Recent sediments and is currently New Zealand's only hydrocarbon producing province (e.g. Palmer and Andrews, 1993; King and Thrasher, 1996; Crown Minerals, 2008). The basin covers an area of approximately $100,000 \mathrm{~km}^{2}$ including the onshore areas of the Taranaki Peninsula and North West Nelson (Figure 2.1; e.g. Crown Minerals, 2008; King and Thrasher, 1996). The basin is bounded to the east by the sub-surface Taranaki Fault and the Patea-Tongaporutu High, which are covered by Late Miocene and Pliocene sediments that are laterally continuous with sediments in the King Country and South Wanganui basins (e.g. Kamp et al. 2004). The other borders of the Taranaki Basin are less well defined: to the south, the Taranaki Basin merges with the sub-basins of the west coast of the South Island; to the west, the basin extends beyond the present continental shelf, and to the north, the basin merges with the Northland Basin (Figure 2.1; King and Thrasher, 1996).

The basin can be divided into two regions of differing tectonic history: the Western Stable Platform and the Eastern Mobile Belt; the latter can be further sub-divided into the Southern Inversion Zone, Tarata Thrust Zone, Central and Northern grabens (Figure 2.1; e.g. Knox, 1982; King and Thrasher, 1996). The Western Stable Platform has largely been undeformed since rifting in the Late Cretaceous, and the grabens and half-grabens formed during this time are preserved beneath a younger sediment cover (e.g. Knox, 1982; Palmer and Andrews, 1993). Conversely, the Southern Inversion Zone and Tarata Thrust Zone is where the Late Cretaceous normal faults have been reactivated as reverse faults and the 
grabens inverted. The Northern and Central grabens have undergone extension during the Miocene, resulting in further normal faulting and volcanism (e.g. King and Thrasher, 1996). The study area of this project is situated over the Southern Inversion Zone and the southern Western Stable Platform.

\subsubsection{Taranaki Basin development}

This section presents a summary of the Taranaki Basin development and related to the New Zealand tectonics; more complete reviews can be found in King and Thrasher (1992; 1996); Kamp et al. (2004); Palmer and Andrews (1993); King et al. (1999) and Stern et al. (2006).

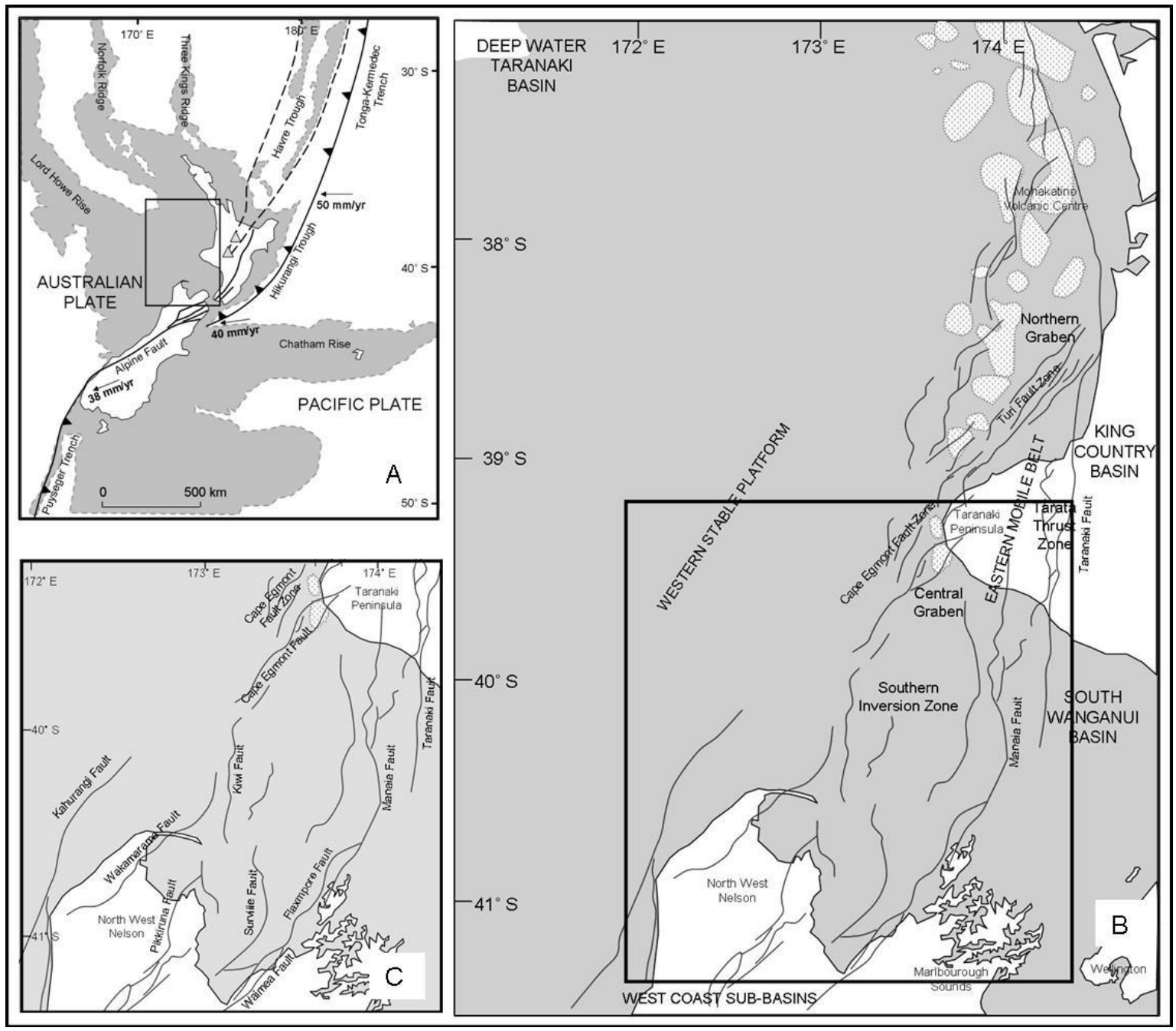

Figure 2.1: (A) New Zealand's present tectonic setting with the submerged Zealandia continent shaded (2000 m bathymetric contour shown) with plate motion vectors after deMets et al. (1994). Triangles symbolise the central North Island volcanics. Note the back-arc location of Taranaki Basin (box) with respect to the subducting plate. (B) Structural zonations of the Taranaki Basin with faults and Mohakatino Volcanic edifices (speckled polygons) shown. Modified after King and Thrasher (1996). (C) Locations of major faults of the southern offshore region of Taranaki Basin. Modified after King and Thrasher (1996). 
Sedimentation in the Taranaki Basin reflects a broad transgressive-regressive sea-level change from Cretaceous to Recent and has resulted in complex spatial and temporal distributions of sedimentary infill (summarised in Figure 2.2). The Taranaki Basin initially formed during Late Cretaceous rifting between Australia and New Zealand. Normal faultbound grabens and half-grabens collected terrestrial sediments, which formed the interbedded coal measures and sandstone sequences of the Pakawau Group (Figure 2.3A; e.g. Palmer and Andrews, 1993; King and Thrasher, 1996). This was followed by a passive margin phase in the Palaeocene and Eocene as the sea transgressed over the entire region, depositing the terrestrial to marginal-marine sequences of the Kapuni Group (Figure 2.3B, C). Continued tectonic quiescence and reduced clastic supply in the Oligocene led to the widespread deposition of limestones and calcareous mudstones of the Ngatoro Group throughout the basin (Figure 2.3D) and throughout New Zealand (e.g. King et al., 1999; King 2000a).

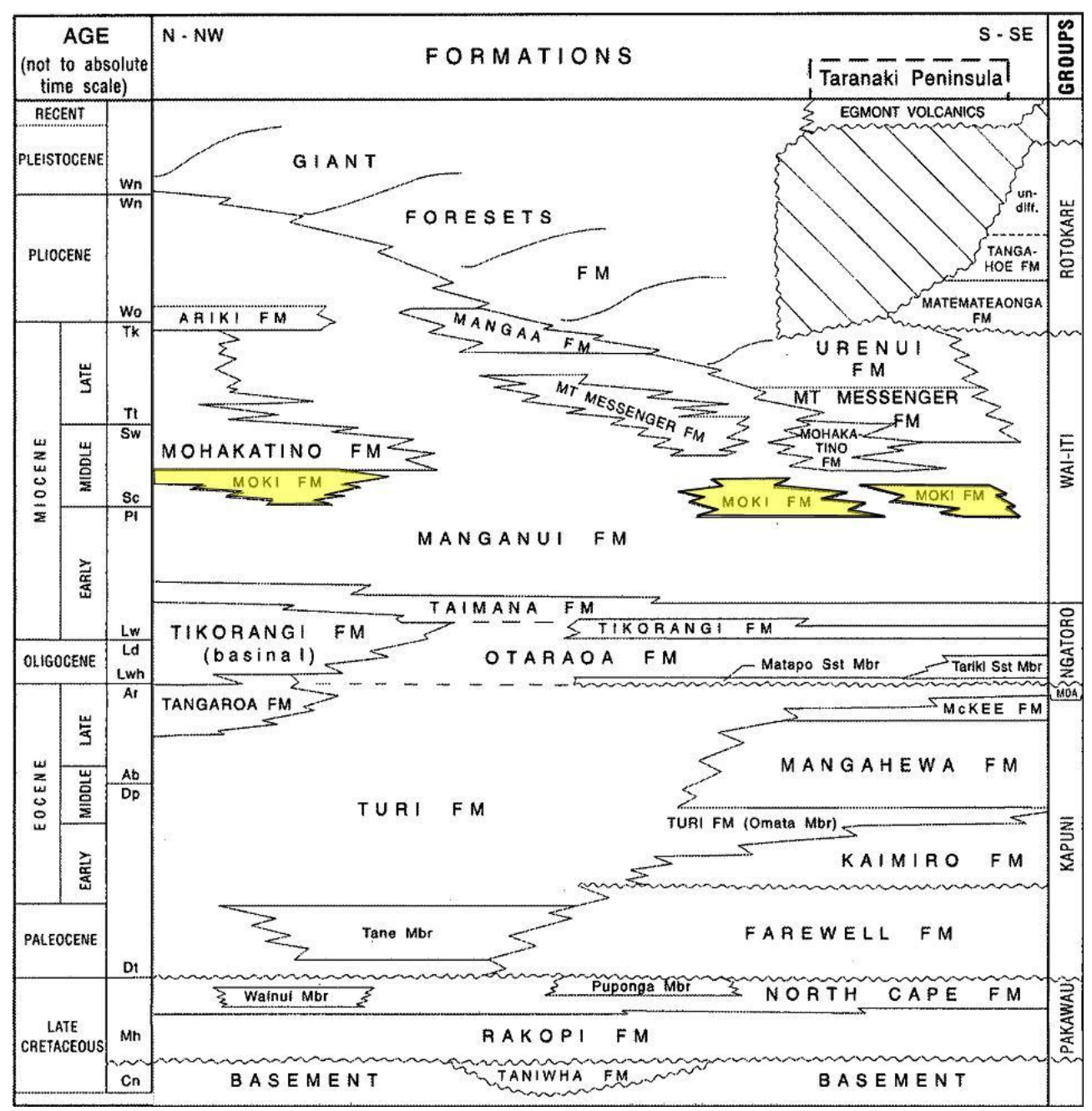

Figure 2.2: Chronostratigraphic panel showing variations in formations across the Taranaki Basin from north-northwest to south-southeast. The Moki Formation (yellow) is present within the Manganui Formation and consists of at least two discrete submarine fan systems. Modified after King and Thrasher (1996). 
The subduction of the Pacific Plate beneath the Australian Plate began in the Oligocene, marking the onset of compression of the New Zealand landmass. In the Taranaki Basin, subsidence curves from wells show broad, coeval bathymetric deepening over a region of $\sim 200 \mathrm{~km}$, including the Western Stable Platform, occurred between 30 and $25 \mathrm{Ma}$ (Late Oligocene) and increased water depths to 1500 m (Holt and Stern 1994a; 1994b). This long wavelength platform subsidence is thought to be related to mantle flow caused by the sinking subducting plate, rather than an advancing flexural foredeep. Terrigenous sedimentation did not begin to infill this depression until the Early Miocene (17 Ma) when the thrust belt emerged above sea level, leading to sub-aerial erosion and increased submarine deposition (Holt and Stern, 1994a; 1994b). Seismic profiles across southern Taranaki Basin, Taranaki Fault Zone and South Wanganui Basin show up to $10 \mathrm{~km}$ of crustal thickening in the Taranaki Fault Zone and around $4 \mathrm{~km}$ of flexural downwarp in the adjacent foredeep (Stern and Davey, 1990). This supports arguments for the development of a Neogene retroarc foreland basin superimposed on the Cretaceous extensional fabric (Stern, 1990; Stern and Davey, 1990; King and Thrasher, 1992).

The subduction-related compression uplifted areas to the south and east of the Taranaki Basin, dramatically increasing the amount of clastic sediment supplied to the foredeep to the west of the Taranaki Fault (e.g. King and Thrasher, 1996). In Taranaki Basin, more than $1000 \mathrm{~m}$ of bathyal mudstone (Manganui Formation) dominates the Miocene interval (e.g. Palmer and Andrews, 1993; King and Thrasher, 1996). The mudstone is interrupted by several interbedded sandstone and mudstone packages, which imply episodes of increased tectonic tempo. These are the turbidite complexes of the Moki, Mount Messenger formations and intra-Manganui sandstones (see Figure 2.2). Accommodation space was filled by high sediment input, which resulted in the shelf, slope and basin-floor fan systems prograding to the north / north-west from Mid Miocene onwards (Figure 2.3F; Palmer and Andrews, 1993). 

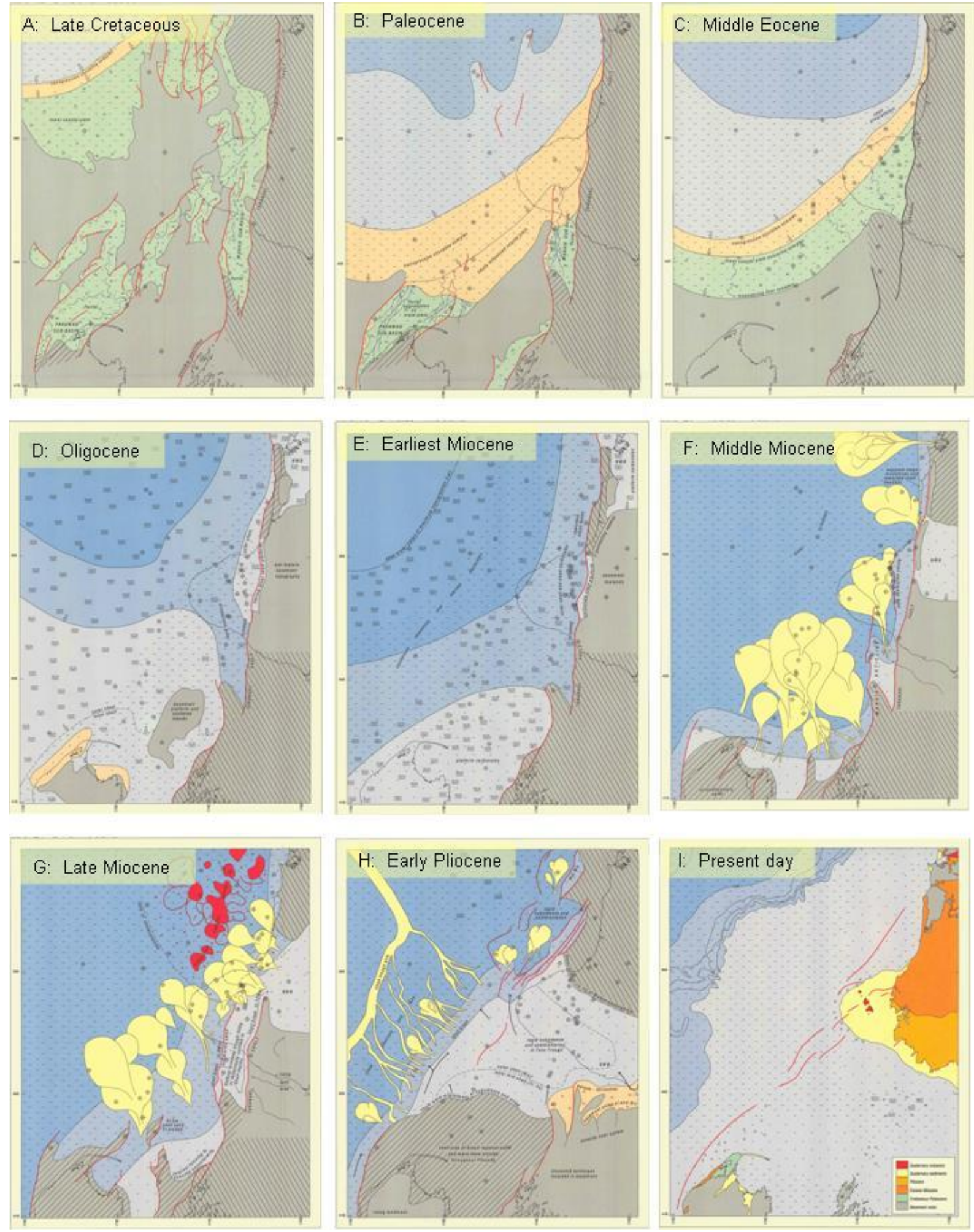

Figure 2.3: Palaeogeographic maps of the Late Cretaceous to Recent sediments within Taranaki Basin.

Note the overall transgression / regression and the resulting sedimentary environments. Modified after King and Thrasher (1996).

Compression reactivated the pre-existing normal faults as reverse faults and inverted the grabens and half-grabens, particularly within the Southern Inversion Zone (King and Thrasher, 1996). It is not certain when fault re-activation was initiated but began with reverse movement along the Taranaki Fault during either Mid to Late Eocene (e.g. Nicol et 
al., 2004) or Early Oligocene times (e.g. Kamp et al., 2004) and was certainly active by Early Miocene (e.g. Nicol et al., 2004; Kamp et al. 2004). Reverse movement propagated southwards along the fault. Between some six and ten kilometres of basement was uplifted to the east before the fault became inactive in the Late Miocene to Pliocene (Stern and Davey, 1990; King and Thrasher, 1996; Kamp et al. 2004). Reactivation of pre-existing normal faults moved westward from Early to Late Miocene. By Mid Miocene times the Manaia Fault was active and had up-thrown the Manaia Anticline to shelf depths in the vicinity of Kupe field (e.g. King and Thrasher, 1996). The Cape Egmont Fault Zone is also interpreted to be an active reverse fault during the Miocene, up-thrown to the southeast (King and Thrasher, 1996). This active faulting influenced the shape of the basin, supply of sediment, and thus the distribution of sub-marine fans.

By Late Miocene, the structural inversion was at a maximum with some inversion structures uplifted above wave base (e.g. structures drilled by the Cook-1, Fresne-1, Tahi1, Surville-1 wells; King and Thrasher, 1996; Vonk and Kamp, 2008). With continued compression and hinterland uplift, sediment input remained high, accelerating the progradation of the shelf and slope and depositing the base-of-slope Mount Messenger Formation fan system (Figure 2.3G).

Tectonic reconstructions (King et al., 1999; King 2000a; 2000b; verified by Wood and Stagpoole, 2007) suggest that the subduction zone migrated from the north of the New Zealand continent near Norfolk Ridge in the Late Eocene to its present location at the Hikurangi Trough. These changes in the direction of tectonic compression in the Latest Miocene to Pliocene resulted in extension in the Northern and Central grabens, accommodated by normal faulting and extrusive (Mohakatino Volcanics) and possible intrusive volcanic activity which migrated southward with time (e.g. King and Thrasher, 1992; 1996; Palmer and Andrews; 1993; King, 2000a).

The change in direction also increased uplift along the Alpine Fault at c. 5 Ma (Adams, 1979; King, 2000a) permitting the erosion of even larger volumes of sediment into Taranaki Basin. This resulted in the deposition of the latest Miocene to Pleistocene Rotokare Group, and in particular led to the development of the large clinoforms (Giant Foresets Formation) as the shelf prograded towards the northwest (e.g. Beggs, 1990; King and Thrasher, 1992). 
The development of the Central North Island volcanics from the Late Miocene to Recent have resulted in a long wavelength up-doming centred over the volcanics (e.g. King and Thrasher, 1992; Brand et al. 1999; Pulford and Stern, 2004; Stern et al., 2006). Evidence for this up doming in Taranaki is expressed in several observations: (1) A 2-3 degree structural dip to the southwest, away from the Central Volcanic Zone, is documented from outcropping sediments along the North Taranaki coast (King and Thrasher, 1992). (2) A Late Miocene / Pliocene unconformity is evident on seismic profiles (Southern and Central Taranaki Inversion Phase (SCTIP) unconformity of Vonk and Kamp (2008)), which, along with overlying strata, has been progressively tilted to the south (Stern et al., 2006).

Rock uplift calculations from sonic porosity logs and coal ranks across the central and western North Island show a doming around the central North Island volcanics (Armstrong et al., 1997; Brand et al., 1999; Pulford and Stern, 2004; Stern et al., 2006) the orientation of which closely matches the strike of major geological units (Kamp et al., 2004). The long wavelength up-doming of the central North Island is further supported by regional isostatic gravity maps (Kamp et al., 2004; Reilly, 1965).

Taranaki Basin is currently volcanically and seismogenically active, with the Cape Egmont Fault (presently dominantly strike-slip) marking the western limit of subduction-related deformation (Sherburn and White, 2006). The Taranaki Basin with its almost continuous sedimentary infill, record the tectonic development and palaeogeography of the western margin of the Zealandia continent through the Cretaceous to Recent times.

\subsection{Sub-marine fans and turbidite complexes}

Modern sub-marine fans are a common depositional environment around the world. Turbidite complexes (ancient sub-marine fans) occur throughout the geologic record and are important features for the oil and gas industry as they provide the reservoirs, seals and stratigraphic traps of many fields (e.g. Mars field, Gulf of Mexico containing more than 4.2 million barrels of oil equivalent (MMBOE); Meckel, 2003). Modern sub-marine fans are mainly studied using indirect methods such as echo sounding and shallow, high resolution seismic reflection surveys which are commonly augmented by piston coring.

Consequently, these depositional environments have only been studied over the last 50 years (Shanmugam, 2000). Our understanding of the geometries and sedimentary processes of modern and palaeoenvironments have benefited from combined research of modern sub-marine fans, ancient turbidite complexes (both outcropping and sub-surface), laboratory experiments and numerical modelling. An enormous volume of literature on the 
sedimentary processes and deposits of deep-marine sediments exists; this section summarises the present understanding in order to understand the deposits of the Moki Formation.

Terrigenous sediment is supplied to the basin-floor by density currents (such as turbidity currents, fluidised flows, liquidised flows, grain flows and debris flows) which vary in their density, support mechanisms, sedimentation mechanisms, resulting in different deposits (summarised in Table 2.1).

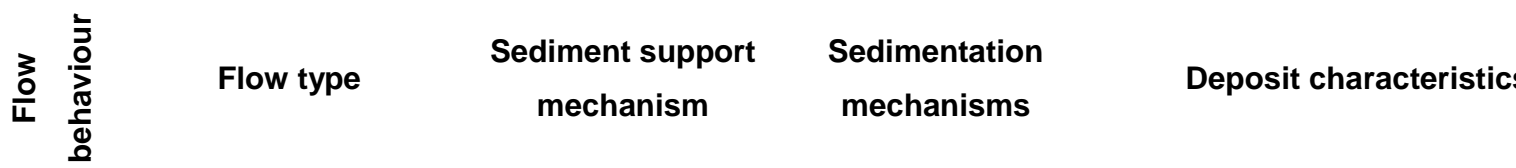

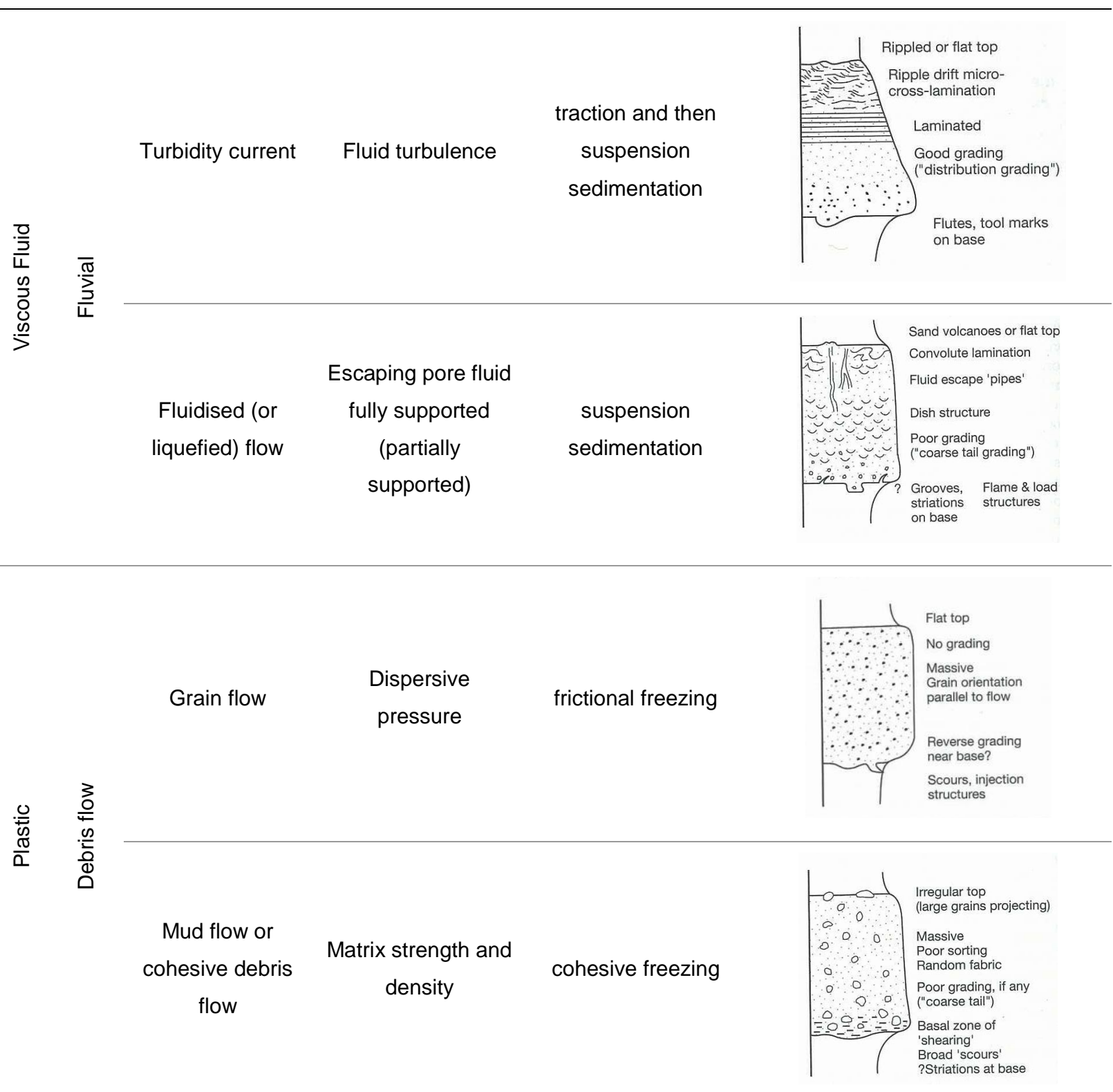

Table 2.1: Summary of deep-water density flows, their suspension and deposition mechanisms and the resulting deposits. After Lowe (1982), deposition characteristic images from Boggs (2001) after Middleton and Hampton (1976). 
Debris flows are very dense, matrix-supported, clay-rich flows initiated on steep slopes and retain energy over long distances, as there is no transfer between sediment and the ambient water. Flow eventually ceases when shear stress no longer exceeds the yield strength at the base of the flow and it freezes. Debris flow deposits are therefore unstratified, poorly sorted deposits that thicken away from the feeder channel (Pratson et al., 2000).

Grain flows are dispersions of cohesionless sediment maintained solely by the dispersive pressure arising from grain-to-grain collisions (Lowe, 1982). Deposition of the grain flow occurs by sudden, frictional freezing primarily by reduced slope. These deposits will be thin (less than $5 \mathrm{~cm}$ for sand; Lowe 1976), inversely graded and inclined at the angle of repose (Lowe, 1982).

Liquefied and fluidised flows are concentrated dispersions of grains in which the sediment is supported either by the upward flow of escaping pore fluid of settling grains or by injected pore fluid (Boggs, 2001). They may either deposit sediments as laminar suspension sedimentation or by accelerating, becoming turbulent and developing into a turbidity current (Lowe, 1982). These flows result in thick, poorly sorted, grain supported deposits with fluid escape structures.

Turbidity currents are by far the most documented mode of sediment supply to sub-marine fans, and are critical to sub-marine fan models (e.g. Normark, 1970; 1978; Walker, 1978). Turbidity currents are flows that occur due to density contrasts between a dense fluid of suspended sediment and the less dense ambient water (e.g. Lowe, 1982; Boggs, 2001). They may be generated by catastrophic events such as earthquakes or sediment failure on a delta front or shelf break, or by a rapid sediment influx from storms, floods or volcanic eruptions (e.g. Walker, 1992a). The turbidity current moves down slope as a dense, sediment cloud and erodes more sediment as its speed increases (Figure 2.4). 


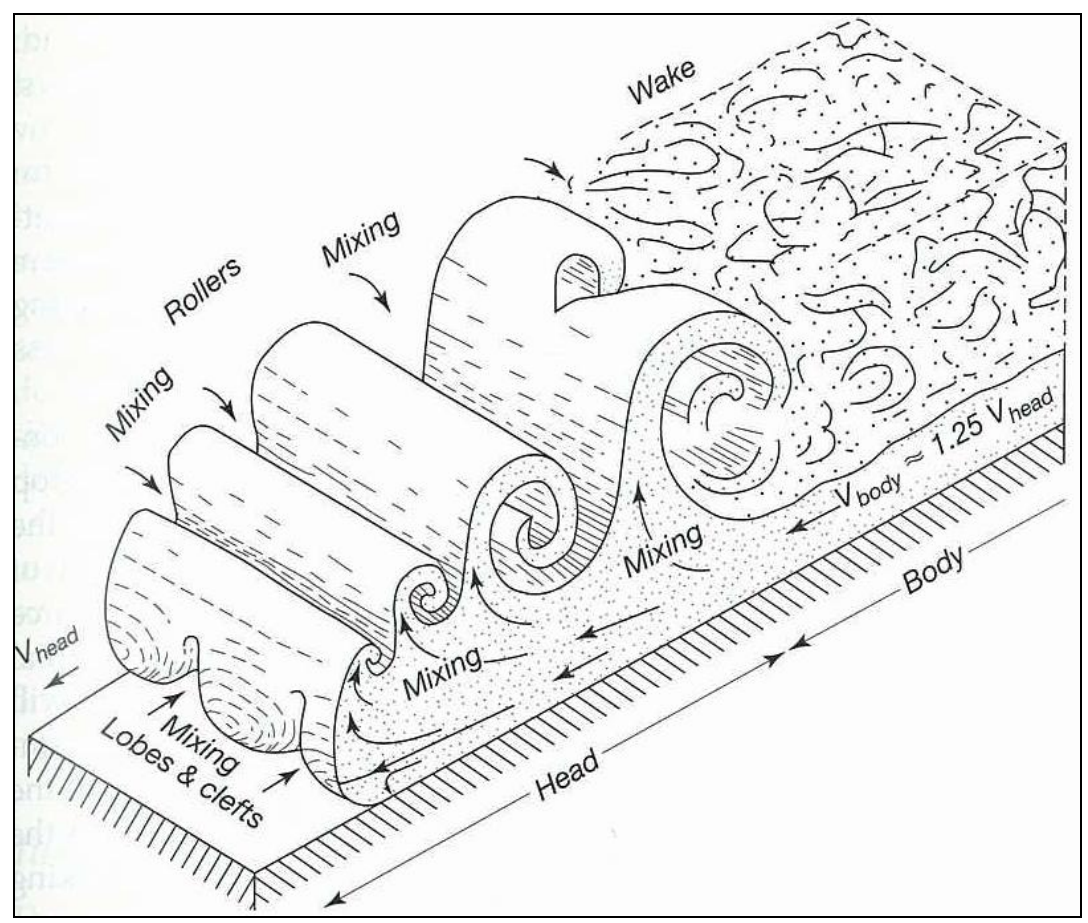

Figure 2.4: Generalised structure of the head and body of a turbidity current. Note the mixing of sediment from the faster body to the head. From Boggs (2001).

Once sediment is in suspension, the flow will continue under the influence of gravity and inertia until the speed is reduced by flattening bathymetry, outward spreading of the flow on the basin floor, mixing with the ambient water, and deposition of sediment at the tail of the current (Boggs, 2001). The coarser and heavier particles settle first as there is not enough energy in the flow to support them; the smallest, lightest particles will remain in suspension until the flow stops (Walker, 1992a). This waning-flow process leads to a wellestablished vertical stratification of the turbidite deposit with clear lateral thinning and fining (Figure 2.5; Bouma, 1962).

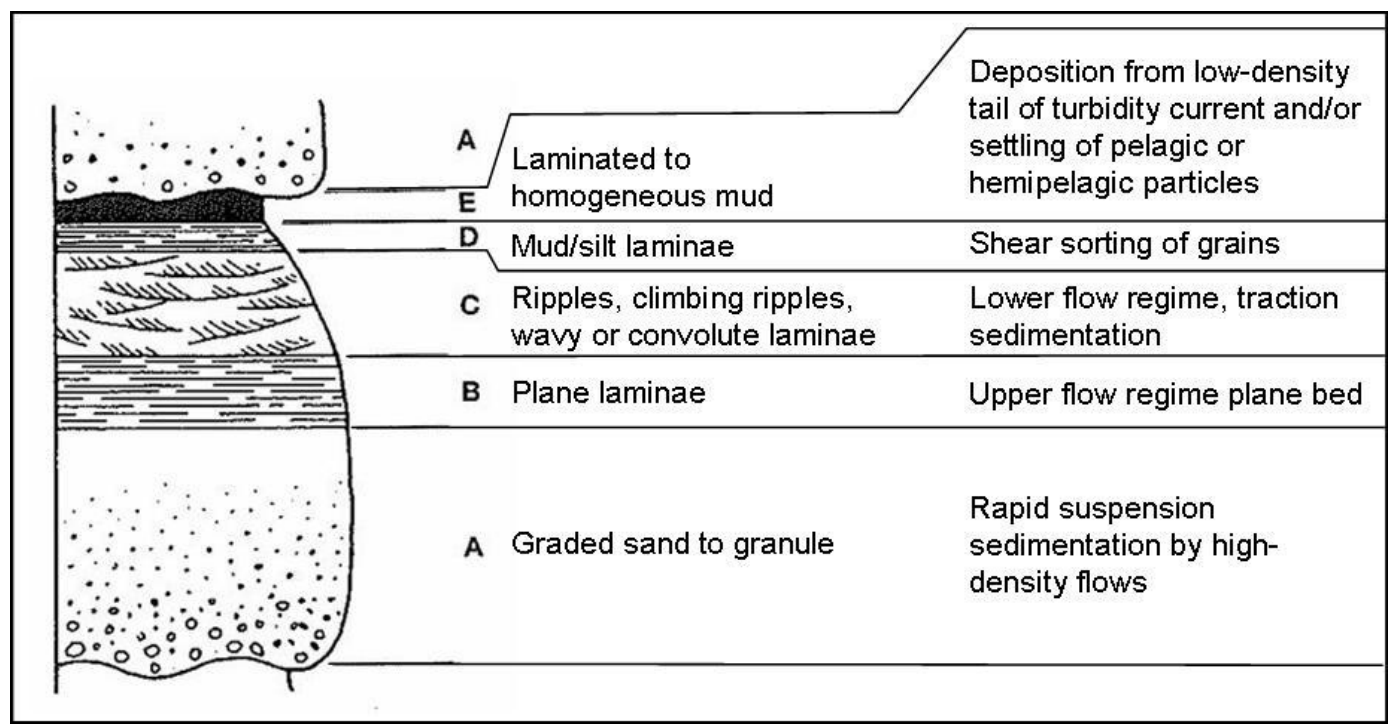

Figure 2.5: Idealised turbidite sequence after Bouma (1962) showing a generalised fining-upwards succession with depositional interpretations after Lowe (1982), Pickering et al. (1989). 
Sub-marine fans are built up by multiple density currents and as each current is affected by the convex shape of the preceding current, the fans often have a complex, compensationalstyle morphology. Each sub-marine fan system is unique and is affected by a number of independent factors such as tectonic setting and activity, climate, relative sea-level variations and sedimentary processes in both the hinterland and the receiving basin (Stow et al., 1985). These are briefly summarised below:

- Tectonics can have a major impact on all aspects of sub-marine fan development, including the type of continental margin; the size, shape and orientation of basins with regard to the coast; the elevation of source areas; distances and gradients between source and sink areas, and the rate and frequency of sediment supply.

- $\quad$ Climate governs the nature and speed of weathering of the original rock; the nature and speed of erosional processes, speed and abrasion of sediment, and chemical changes to sediment temporarily stored in shallow areas.

- $\quad$ Relative sea-level fluctuations are caused by local tectonic influences and glacioeustatic sea-level changes, controlling the amount and timing of sediment reaching the slope and basin-floor. During high-stands, sediment is preferentially stored on the coastal plain, delta and shelf and may not reach the basin floor until the next low stand or rising sea level (Shanmugan and Moiola, 1982). For this reason, most of the modern sub-marine fans are currently inactive.

- $\quad$ The sediment mineralogy, size and shape also play an important part on the efficiency of the turbidite flow and therefore the size and geometry of the fan system (Mutti, 1985; Reading and Richards, 1994).

Due to the complex interacting factors creating generic fan models is highly problematic (e.g. Anderton, 1995; Bouma, 2000; 2004). Some of the more widely used models are the early ones (e.g. Normark, 1970; Walker, 1978). These models simply divide a sand-rich fan into three broad areas based on their morphology, sediment dispersing processes and resulting stratification; the upper, mid and lower fans of Normark (1970) (Figure 2.6). 


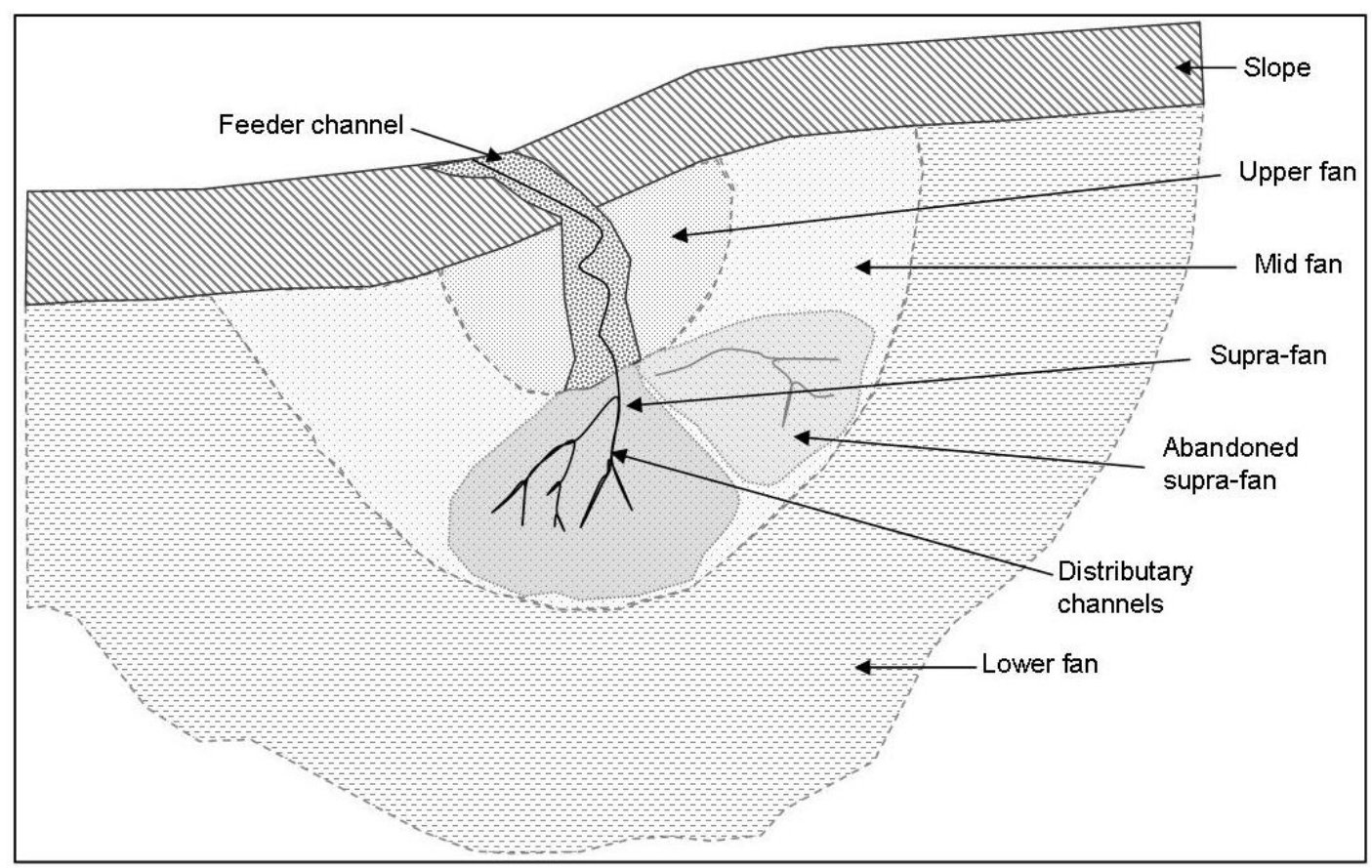

Figure 2.6: Sub-marine fan model of Normark (1970), with the main morphological features of the upper fan (white), mid fan (grey) and lower fan (stippled) depicted. Modified after Normark (1970; 1978).

The upper fan is closest to the slope and is characterised by one large depositional valley up to several kilometres in width and is typically filled with coarse-grained sediment that settle first. The prominent levees of the depositional valley are made-up of finer-grained deposits of sandstone, siltstone and mudstone (Normark, 1978; Walker, 1978).

The mid fan is built by a number of coalescing suprafans which are small fans on the mid fan surface. The upper part of the supra-fan is characterised by a number of channels and a higher sand content; the lower part of the suprafan is topographically smooth and merges with the lower fan (Walker, 1978). Within the channels of the suprafan, massive and pebbly sandstones may be deposited. Only one supra-fan will be active, until the next large turbidity current creates a new supra-fan. Often the supra-fans coalesce which may mean that an abandoned fan and its channels may become active in the future (Normark, 1978). Whilst a supra-fan is inactive, it may be covered with a fine-grained hemipelagic mud that could provide a hydrocarbon seal (Walker, 1978). Anderton (1995) argues that unlike the upper and lower fans, the mid-fan environment is dependant on the size of each consecutive turbidity current; therefore, the distribution of sands is chaotic and unpredictable.

The lower fan is most distal and is built up by sheet-like turbidites creating a characteristically smooth, channel-free, low-gradient plain, which merges with the basin floor (Normark, 1978). Slow hemipelagic deposition occurs on the lower fan, 
intermittently interrupted by turbidites (Walker, 1978). These turbidites are the classic Bouma sequences, which thin towards the basin-floor (Walker, 1978).

Sediment type plays an important role in the transportation style and hence the size and shape of the resulting fan system. Sand-rich turbidity currents tend to lose energy quickly as the sand is only supported by a turbulent water column and consequently sand grains settle close to the feeder channel. Coarse-grained, sand-rich turbidite complexes have a high net:gross sand ratios $^{1}$ (Bouma, 2000). Sediment forming these turbidite complexes travels a short distance from source (Figure 2.7A). Transportation of sediment in these circumstances has been termed non-efficient by Mutti (1985).

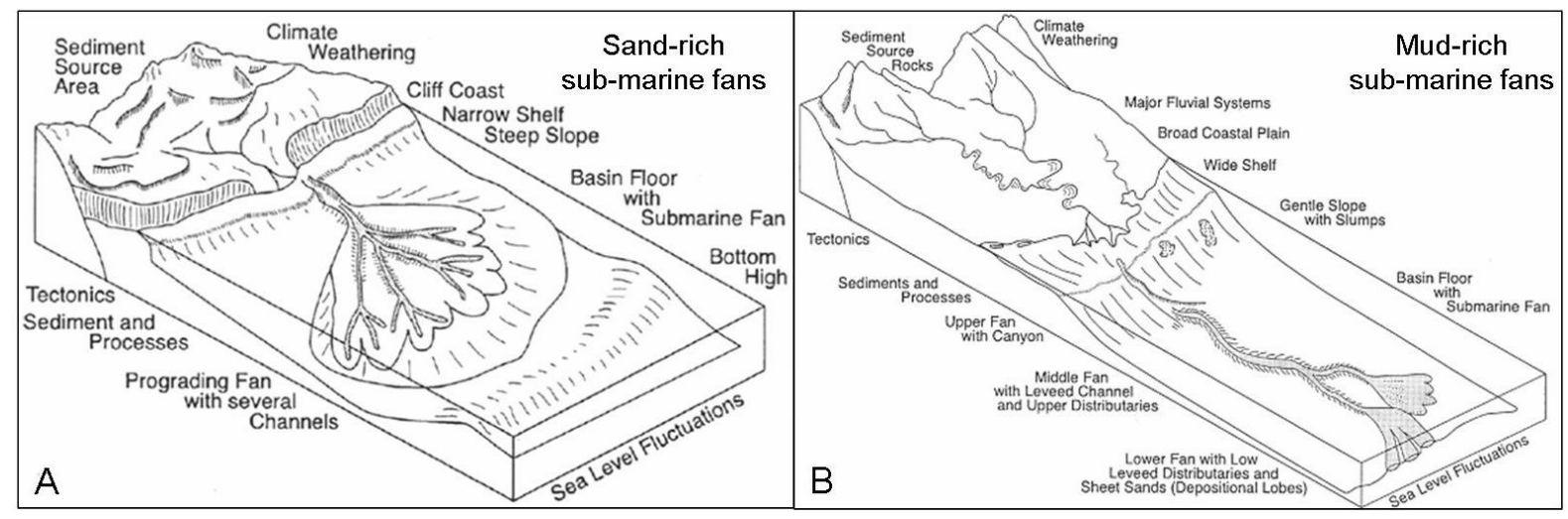

Figure 2.7: Schematic block diagrams of end-member model of (A) a coarse-grained, sand-rich sub-marine fan and (B) a fine-grained, mud-rich sub-marine fan emanating from a single point-source. The sand-rich sub-marine fan is found with a short source to sink distance, with a narrow coastal plain and shelf and, steep slope. In contrast, the mud-rich fan is found with a long sediment transport distance involving a broad coastal plain, delta and wide shelf. Other features affecting sub-marine fan character are shown. Modified after Bouma (2004), after Bouma (2000), Reading and Richards (1994) and Stow et al. (1985).

In contrast, mud-rich turbidity currents retain their energy and the resulting fans can be very large, elongate and extend far from the slope (Figure 2.7B; Reading and Richards, 1994). These fans have long, gentle transport pathways, are delta-fed, with broad coastal plains and shelf and are of high-efficiency (Mutti, 1985) resulting in a bypassing system a long way from source (Bouma, 2004).

In summary, sub-marine fan morphology is highly variable, controlled by tectonics, climate, relative sea-level, sediment supply and type. Density flows transport sediment to the fans via feeder channels on the slope or mass-wasting on the slope usually during low

\footnotetext{
${ }^{1}$ Net:gross sand ratio is the sum of the thickness of all the sandstone beds of a formation or unit of interest divided by the total thickness of the formation or unit of interest (North, 1985).
} 
stands. Large flows deposit sheet-like sandstones which grade laterally to more distal turbidites, whilst smaller flows will be constrained to distributary channels on the fan surface, depositing their load on supra fans. This overview provides the framework of the fundamental sedimentary processes involved in developing sub-marine fans which can be applied to understanding the development of the Moki Formation.

\subsection{Moki Formation}

\subsubsection{Description}

The Moki Formation is entirely sub-surface, and therefore, geological information is restricted to cuttings, sidewall cores, the few conventional drill cores, wireline logs and seismic profiles. The formation is a fine to very fine-grained, moderately well sorted, sandstone dominated sequence interbedded with mudstone and minor limestone horizons (Lock, 1985). It typically has a distinct wireline log signature of stacked tabular, sandstone packages with sharp upper and lower contacts between the marine mudstone of the Manganui Formation (King and Thrasher, 1996). On seismic reflection profiles, the top of the Moki Formation produces a high-amplitude response (de Bock, 1994). From this, it is understood that the formation is present through most of the Eastern Mobile Belt and parts of the Western Stable Platform (Lock, 1985; Palmer and Andrews, 1993; de Bock, 1994; King and Thrasher, 1996).

\subsubsection{Definitions}

The Moki Formation was originally named the Mokau Formation Equivalent after the Mokau Formation in the Wanganui Basin of similar age and lithology (Lock, 1985; King and Thrasher, 1996). However, the two formations are distinctly different, as the Mokau Formation contains conglomerates, coals and shell beds, which are not present in the time equivalent rocks of Taranaki Basin (Lock, 1985). To reduce confusion and aid communication, Lock (1985) formally defined the Moki Formation as a sandstone dominated sequence of Altonian to Tongaporutuan age. This was subsequently restricted by King (1988) to the Late Altonian to Early Lillburnian as other distinct Miocene sand bodies are present in the basin, namely the Tongaporutuan-aged Mt Messenger Formation. This definition includes the Moki B Sandstone referred to in some literature (e.g. Shell Todd Oil Services, 1993; Bussell, 1994). The Moki Formation overlies and is overlain by the massive marine mudstone of the Manganui Formation (Figure 2.2). 
In the Maari field a localised Lillburnian-aged sandstone (named the M2A Sandstone) lies stratigraphically above the Moki Formation. Following the definition of King (1988) this sandstone is technically included in the Moki Formation; however, a 50 m mudstone interval separates the two (Tricentrol Exploration Overseas Ltd, 1985). The M2A sand represents a further, single influx of sandy sediment to the basin after deposition of the main body of the Moki Formation. Because of the distinct interval of mudstone above the top Moki Formation, the M2A sand is not considered part of the Moki Formation in this thesis and is treated as a separate sandstone within the Manganui Formation (see also de Bock et al., 1991).

Within the study area there is a Latest Lillburnian / Waiauan aged sandstone package separated from the Moki Formation by 200-300 m of Manganui Formation mudstone. This younger sandstone has been called the Moki A Sandstone by some oil companies (e.g. Shell Todd Oil Services, 1993; Bussell, 1994; New Zealand Overseas Petroleum Ltd, 2003). This nomenclature is confusing as correlation shows this sandstone is not part of the Moki Formation. This sandstone is included within the definition of the Mount Messenger Formation of King and Thrasher (1996) as a Late Lillburnian to Tongaporutuan sandstone package. However, an age of Late Waiauan to Tongaporutuan was used by King and Browne (2001) for the Mount Messenger Formation. For simplicity, the name $\mathrm{S} 1 / \mathrm{Sw}$ (Lillburnian / Waiauan) Sandstone is used here to describe this sandstone package.

Furthermore, wireline log analysis (see Chapter 5) has identified a Lillburnian-aged shelfal sandstone in the Motueka-1 well, previously named the Mount Messenger Formation Equivalent. As the deep-water Mount Messenger Formation and this shelfal sandstone were deposited in different sedimentary environments and are not directly correlatable, the name Mount Messenger Formation seems inappropriate. No Mid Miocene shelfal sandstone has been named in the Taranaki Basin, however, a Lillburnian to Waiauan aged shelfal sandstone, named the Otunui Formation, outcrops in the King Country Basin. As the Taranaki and King Country basins have been interpreted to be part of the same system at this time (e.g. King and Thrasher, 1992; 1996; Kamp et al., 2002; 2004) the name Otunui Formation Equivalent has been adopted for this sandstone in this study.

\subsubsection{Environment of deposition}

The Moki Formation is well established as a turbidite complex with evidence from the abundance of mid- to lower-slope foraminiferal assemblages and is supported by core, 
wireline log and seismic facies (e.g. Lock, 1985; Palmer and Andrews, 1993; de Bock, 1994; Bussell, 1994; King and Thrasher, 1996). Wireline log analyses show an overall coarsening and thickening upward sandstone package suggestive of fan progradation (Palmer and Andrews, 1993; de Bock, 1994; King and Thrasher, 1996; c.f. Walker, 1978) and sandstones become progressively younger northwards (King and Thrasher, 1992; King and Browne, 2001).

The Moki Formation of onshore Taranaki Peninsula and offshore southern Taranaki Basin (Figure 2.9) are distinctly different in their texture, mineralogy, distribution patterns and diagenetic alteration (Palmer and Andrews, 1993). This has lead many authors (e.g. Palmer and Andrews, 1993; King and Thrasher, 1996) to suggest the Moki Formation from these areas are two individual sub-marine fan systems feeding from different sedimentary sources. Provenance studies suggest sediment supply was from a plutonic and subordinate metamorphic source in the south for the offshore fan system (possibly from Separation Point Granite, North West Nelson) and from metasediments and igneous rocks in the east (or southeast) for the onshore fan system (Palmer and Andrews, 1993; Higgs, 2004).

Previous regional interpretations (e.g. Lock, 1985; de Bock, 1994; King and Thrasher, 1996) of the Mid Miocene palaeogeography based primarily on well data and have produced varying results. These interpretations generally agree at well locations but differ in areas of little or no well control. These interpretations are briefly summarised below.

In addition to defining the Moki Formation, Lock (1985) produced a summary of the formation over the entire Taranaki Basin using the broad definition, which includes the Mount Messenger Formation. The author presented isopach, sandstone percentage, sandstone thickness, and age distribution maps contoured from well data. Through the Maui Field, Lock (1985) observed that sandstone percentage decreases to the northwest and suggested that Moki distribution was affected by the contemporaneous movement on the Cape Egmont Fault Zone. Lock (1985) concluded that sediment was sourced from the southwest, in part based on the presence of 30 - $50 \mathrm{~m}$ thick sandstone beds previously interpreted from wireline logs in the Kiwa-1 well completion report (Shell BP and Todd Oil Services, 1982) which later proved to be incorrect (de Bock, 1994). No palaeogeographic reconstruction was created as part of this report. 
De Bock et al. (1991) and De Bock (1994) presented a study of the facies distribution and provenance of the Moki Formation in southern offshore Taranaki Basin. This was achieved through wireline log analysis and correlation, cuttings and core observations. From these, the authors inferred a southerly sediment source and suggested the Separation Point Granite in North West Nelson. In this interpretation (Figure 2.8), the fan system of the Moki Formation is depicted as restricted and elongate, trending north-northeast parallel to the slope to the east of the fan system, with the central part of the fan running through the Maari and Maui fields. Sediment is supplied to the marine environment via a delta system and a broad shelf. Sub-marine canyons are carved into the outer-shelf and merge into a single, meandering channel, which is present through the entire length of the shown system. Much less sediment is supplied to the basin floor from the north-east/south-west trending slope. Another river system is shown to feed the onshore peninsula fan system.

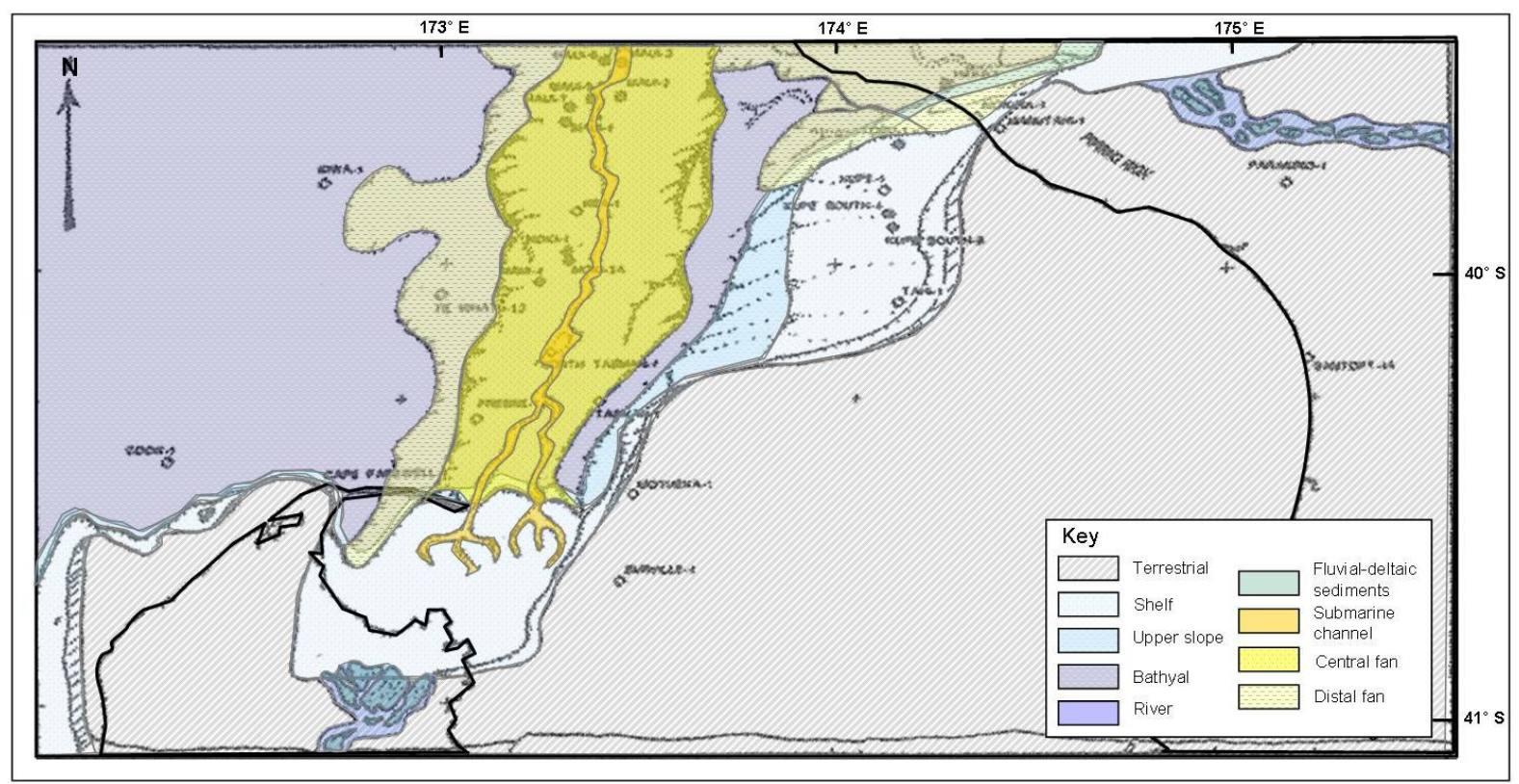

Figure 2.8: De Bock's (1994) interpretation of the palaeogeography of the southern Taranaki Basin during the deposition of the Moki Formation showing a delta-fed elongate fan system. Modified after de Bock (1994).

King and Thrasher (1996) interpreted the Moki Formation to be comprised of a series of coalescing and overlying balloon-shaped fans systems sourced from the south (Figure 2.9). The largest of these fan systems is in the southern offshore region where sediment is sourced from the south and fed from a number of feeder channels along a roughly eastwest trending slope. Similar to the de Bock (1994) interpretation, the central part of the fan system is located from Tasman-1 to the Maui Field and fan margins are near Kiwa-1 and Te Whatu-2. Fans are inferred to be present to the east of the Tasman-1 to Maui Field trend, though no wells have been drilled in the region to confirm. The fan system does not 
reach far beyond the Maui Field in the north. The Manaia Fault is interpreted to be active at the time of Moki Formation deposition, affecting the shape of the basin and influencing sandstone distribution. Fine-grained, distal turbidites also occurred beyond the main fans, as seen in Taimana-1 and Witiora-1. According to the authors, the basin floor sloped down towards the abyssal plain of the New Caledonia Basin.

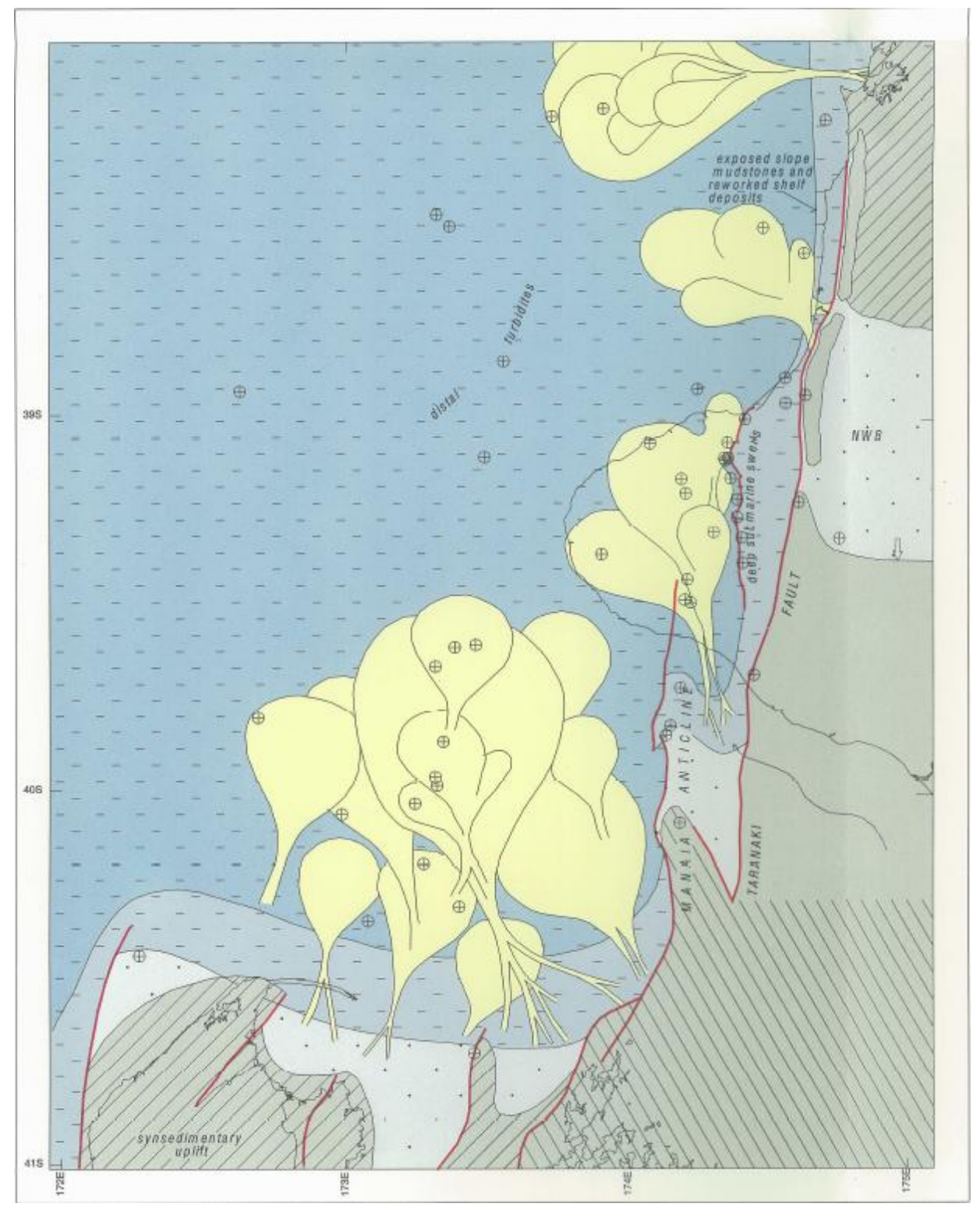

Figure 2.9: Palaeogeography map during the Mid Miocene as interpreted by King and Thrasher (1996). The yellow fans represent the depositional lobes of the Moki Formation. Note several discrete fan depocentres in the Taranaki Basin. From King and Thrasher (1996).

In addition to these general models, localised studies have provided more detail to the present knowledge of the Moki Formation (see de Bock et al., 1991; Bussell, 1994; Dauzacker et al., 1996; Rogers et al., 2000; Engbers, 2002). For example, spectacular south-north trending channels through the Maui area have been imaged by Bussell (1994) by various attribute analyses on the Maui 3D dataset. Dauzacker et al. (1996) and Rogers 
et al. (2000) showed from isopach maps, that the Maui-4 and Moki-Maari structures were beginning to rise at top Moki to top M2A sand, causing thicker sedimentation in the trough between these highs.

\subsubsection{Reservoir potential of the Moki Formation}

The high percentage of sandstone (average 47\% net/gross sandstone), with amalgamated sandstone packages up to 100 metres thick (King and Thrasher, 1996) make the Moki Formation an attractive petroleum exploration target. Sandstones are generally fine- to very-fine grained with grain size and sandstone bed thickness increasing upwards (King and Thrasher, 1996). Matthews and Mills (2001) showed that Miocene sandstones of Taranaki Basin are generally of good reservoir quality (at least $20 \%$ porosity and $100 \mathrm{mD}$ permeability) down to maximum burial depths of $3200 \mathrm{~m}$ bsl. Better reservoir quality is noted for the offshore wells than the onshore thought to be associated with the higher proportion of quartz (from different sediment source types) in the offshore region (Higgs, 2004).

Hydrocarbons are yet to be commercially produced from the Moki Formation on onshore Taranaki Peninsula, though hydrocarbon shows have been documented in some of the onshore wells e.g. Kaimiro-1 and Kaimiro-2 (Smale et al., 1999) and Ngatoro-3 flow tested gas from this formation (King and Thrasher, 1996). Onshore, the Moki Formation is less sandy, more argillaceous and tends to have lower porosities than the offshore region, thereby reducing the ability of containing economic volumes of hydrocarbons, and lower permeability reduces its production capabilities (e.g. Mathews, 1989, Martin, 1990; 1991; 1993; 1995; Challis, 1990; Core laboratories, 1993; Davies, 1997; Smale et al., 1999). Diagenesis plays a large part in reducing the porosity of sandstones, particularly the deformation of ductile grains into pore spaces during compaction (e.g. Martin, 1990, 1991, 1993; Matthews 1989). However, diagenetic effects are often localised and depend on the composition of formation water and maximum burial depth as much as the original mineralogy of the sediment. The Moki Formation may still be a significant hydrocarbon target onshore.

Offshore the Moki Formation has proven to contain producible hydrocarbons. Average sandstone porosities are around 21-23\% in the Maui B, Moki-Maari and Maui-4 areas and permeabilities of up to $588 \mathrm{mD}$ were documented in Moki-1 (Tricentrol Exploration Overseas Ltd, 1985; Dauzacker et al., 1996; King and Thrasher, 1996; Engbers, 2002). Oil 
was produced at a rate of 660 barrels of oil per day (BOPD) in the Moki-1 well (Tricentrol Exploration Overseas Ltd, 1984; Dauzacker et al., 1996) and at a maximum rate of 4370 BOPD in the horizontal Maari-1A well (Shell Todd Oil Services, 1999; Rogers et al., 2000). Hydrocarbon shows in the Moki Formation have also been recorded in Maui-4 (Shell BP and Todd Oil Services, 1970), Moki-2A (Tricentrol Exploration Overseas Ltd, 1985), Maui-2, MB-Z(11) (Shell Todd Oil Services, 1993; Engbers, 2002), and Kea-1 (King \& Thrasher, 1996). The Maari field is currently under development with production of oil from the Moki Formation expected to commence in early 2009 (Leeb, 2008). Thus, the Moki Formation in offshore, southern Taranaki Basin is an attractive hydrocarbon exploration target.

The M2A Sandstone also had strong shows reported and high core porosities between 27 and $29.6 \%$ with permeabilities ranging from 1 to $600 \mathrm{mD}$ in the Moki-2A well (Dauzacker et al., 1996). In Maari-1 porosities of $\sim 26 \%$ and oil saturations of $\sim 70 \%$ were documented (determined from petrophysical analysis; Rogers et al., 2000). This sandstone is therefore also considered a viable prospect in this area.

\subsection{Summary}

In summary, the Moki Formation was deposited as a sand-rich turbidite complex in mid to lower bathyal water depths in the retro-arc foreland basin of the Miocene Taranaki Basin. Sediments were sourced from rising hinterland to the south and east thought to be comprised of plutonic and subordinate metamorphic rock to the south (possibly the Separation Point Granite), and metasedimentary rock in the east. The central fan of the southern Moki Formation sands appears to be located along a south-north trend from North Tasman-1 to the Maui Field, with Kiwa-1 located in a distal fan position. This review of the background geology shows that whilst the general geology of the Taranaki Basin during the time of Moki Formation deposition is well established, much of the detail is poorly understood. 


\subsection{Regional Seismic Interpretation}

\subsection{Introduction}

Seismic interpretation is a fundamental tool for the analysis of sub-surface strata and identification of hydrocarbon accumulations. As such, the oil and gas industry has acquired a large database of seismic reflection profiles over the southern Taranaki Basin, which now exists in the public domain. This database was utilised for this study to provide a regional interpretation of the Moki Formation and its equivalents, which was a necessary precursor to seismic facies interpretation, which in turn helps to constrain the Mid Miocene palaeogeography. This chapter discusses regional mapping of Mid Miocene sediments, including the Moki Formation, within the study area and their changes in thickness and seismic character.

\subsection{Data}

A database of nearly $30,000 \mathrm{~km}$ of tied and phase-matched 2D seismic data and two 3D datasets (Appendix C) with 13 wells was provided by GNS from their seismic facies mapping (SFM) project (Figure 3.1). The wells were Kea-1, Maari-1, Maui-1, Maui-2, Maui-3, Maui-4, Maui-7, MB-P(8), Moki-1, Moki-2A, North Tasman-1, Tahi-1 and Te Whatu-2. All wells within the study area were reviewed and consequently 13 additional wells were added to the project using open file data held by the Ministry of Economic Development. These wells were Cape Farewell-1, Fresne-1, Hochstetter-1, Kiwa-1, Maui5, Maui South-1, MB-Z(11), Motueka-1, Pukeko-1, Rahi-1, Surville-1, Tasman-1 and Tui1. Well data included in this project includes location, total depths, depth datums, timedepth curves, deviation data, wireline log curves, formation tops and stage boundaries (Appendix D). Several issues were encountered with velocity curves at some wells, the details and solutions of which are contained in Appendix D. Formation tops were revised after seismic and wireline log correlation (see Chapter 5). 


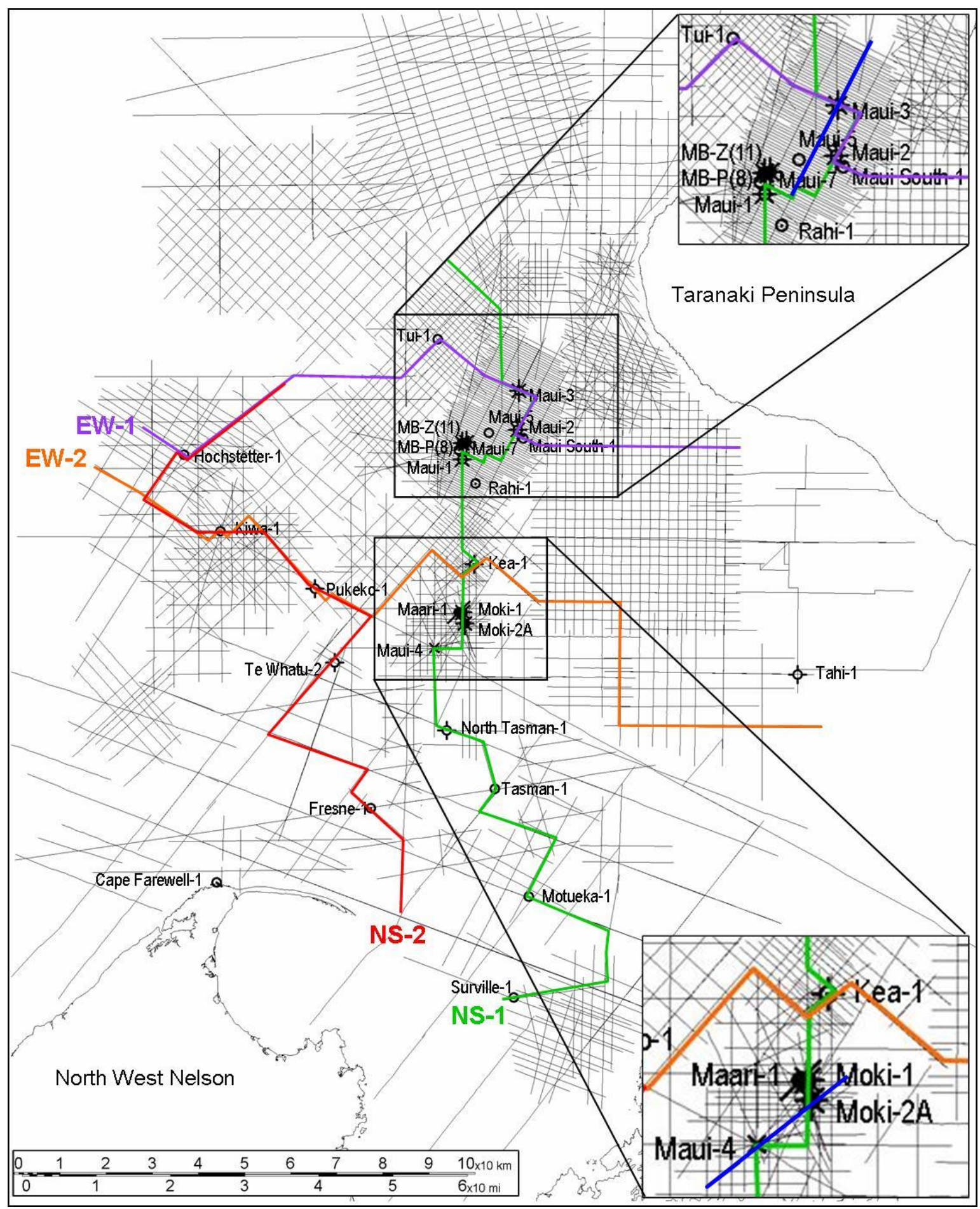

Figure 3.1: Map showing the seismic dataset, from which seismic lines were selected for use in this study and the wells used are shown. The four coloured lines show the location of regional composite lines created: NS-1 (green; Figure 3.6), NS-2 (red), EW-1 (purple) and EW-2 (orange; Figure 3.7). Lower inset box shows the location of seismic line ct95-12 (blue) shown in Figure 3.2. Upper inset box shows the location of seismic line 86ma-103 (blue) shown in Figure 3.3.

\subsection{Interpretation methods}

Standard seismic interpretation methods were utilised for regional interpretation. This was performed with Zokero ${ }^{\mathrm{TM}}$ Seisware version 6.5 seismic interpretation software on a Dell 
Precision 390 workstation. The following steps were taken for regional seismic interpretation:

1. Wells were calibrated to seismic lines using the velocity curves published in well completion reports.

2. The well-to-seismic ties were verified by seismic correlation of several stratigraphic markers between wells.

3. Where there appeared to be a poor well-to-seismic tie, the velocity curve and depth reference points were re-checked. Where wells had no, or a particularly poor, timedepth curve, velocity curves from neighbouring wells were substituted (see Appendix D).

4. Four regional composite lines were created from different surveys of varying quality and vintages as there are no single lines crossing the entire study area. Of these regional composite lines, two trend north-south (NS-1 and NS-2) and two trend east-west (EW-1 and EW-2). These lines intersect the key wells (Figure 3.1).

5. Six seismic horizons were interpreted on these four composite lines. The horizons correlate to the top Moki Formation, near base Moki Formation, top S1/Sw sandstone, near top Altonian, near top Clifdenian and near top Lillburnian (see section 3.4).

6. The coarse grid over the study area, formed by the regional composite lines (Figure 3.1), was subsequently refined by seismic horizon interpretation along infill lines that connect the regional lines together.

7. Major faults offsetting Mid Miocene sediments were interpreted. Additional fault interpretation was provided by Hannah Bushe at GNS Science. Interpreted faults were triangulated, and fault shadow zones, representing fault location and its dip, were created (Figure 3.4).

8. At areas of difficult seismic horizon interpretation, such as at faults, incised channels, zones of incoherent reflectors or across seismic lines, particularly those of different surveys, the seismic character was initially matched across the zone of uncertainty. This was then checked by circling along different lines (loop tie). In some cases large loop ties were required.

9. Structure contour maps were created by gridding the initial interpretations (firstpass) to check for seismic horizon misinterpretations that appear as geologically unreasonable contour groupings, such as bow tie patterns. The misinterpreted lines 
were then checked with loop ties back to wells and the regional lines, and the maps were then re-contoured.

10. Final two-way travel-time (TWTT) structure maps of interpreted horizons were gridded using a minimum curvature method constrained to a polygon of the study area, with a grid spacing of $1000 \mathrm{~m}$ and smoothed once. Contours were generated with a spacing of 50 milliseconds (ms). Isopach maps were created by calculating TWTT isochrons between two interpreted horizons and were then gridded.

11. Areas with significant changes in seismic character were noted and subsequently studied in more detail. These seismic facies are described in more detail in Chapter 4.

No time-to-depth conversion was done as part of this project.

\subsection{Interpreted horizons}

Six horizons were interpreted throughout the region to define the stratigraphic section of interest on seismic. Three of these horizons represent lithostratigraphic horizons (near base Moki Formation, top Moki Formation and top Sl/Sw Sandstone) and three represent approximate New Zealand stage boundaries (near top Altonian, near top Clifdenian and near top Altonian). These are described in more detail below. Additional horizons were interpreted locally to provide more detail (e.g. M2A Sandstone in the Moki-Maari area).

\section{Top Moki Formation}

The top of the Moki Formation is typically marked by an abrupt change from the thick, blocky sandstone packages of the Moki Formation to a relatively homogeneous mudstone of the Upper Manganui Formation above. This distinct lithology change provides a good acoustic impedance contrast that corresponds to a moderate to high amplitude reflector (Figure 3.2). Due to the periodic switching of fan lobes in a turbidite system, the top of the formation is not always consistent throughout the area. Thick sandstones deposited in the centre of the fan lobes grade laterally to thin mudstones at the fringe of the fan lobe which is represented on seismic by a thinning and fading of reflectors with distance. In general, the top Moki Formation was picked with a good degree of confidence through the centre of the study area. 
The top Moki Formation was interpreted beyond the centre of the study area where the seismic character changes significantly and accordingly the Moki Formation Equivalent was picked with less confidence. In the south and east of the study area, reflectors are low amplitude and incoherent. Dipping reflectors (after the structural tilting has been accounted for) in these areas were interpreted as slope, and the high amplitude flat-lying or very slightly dipping reflectors farther to the south and east were interpreted as shelf (see further discussion in sections 3.5.2 and 4.3.1). On the Western Stable platform, reflectors vary in amplitude and continuity, and generally thin towards the northwest.

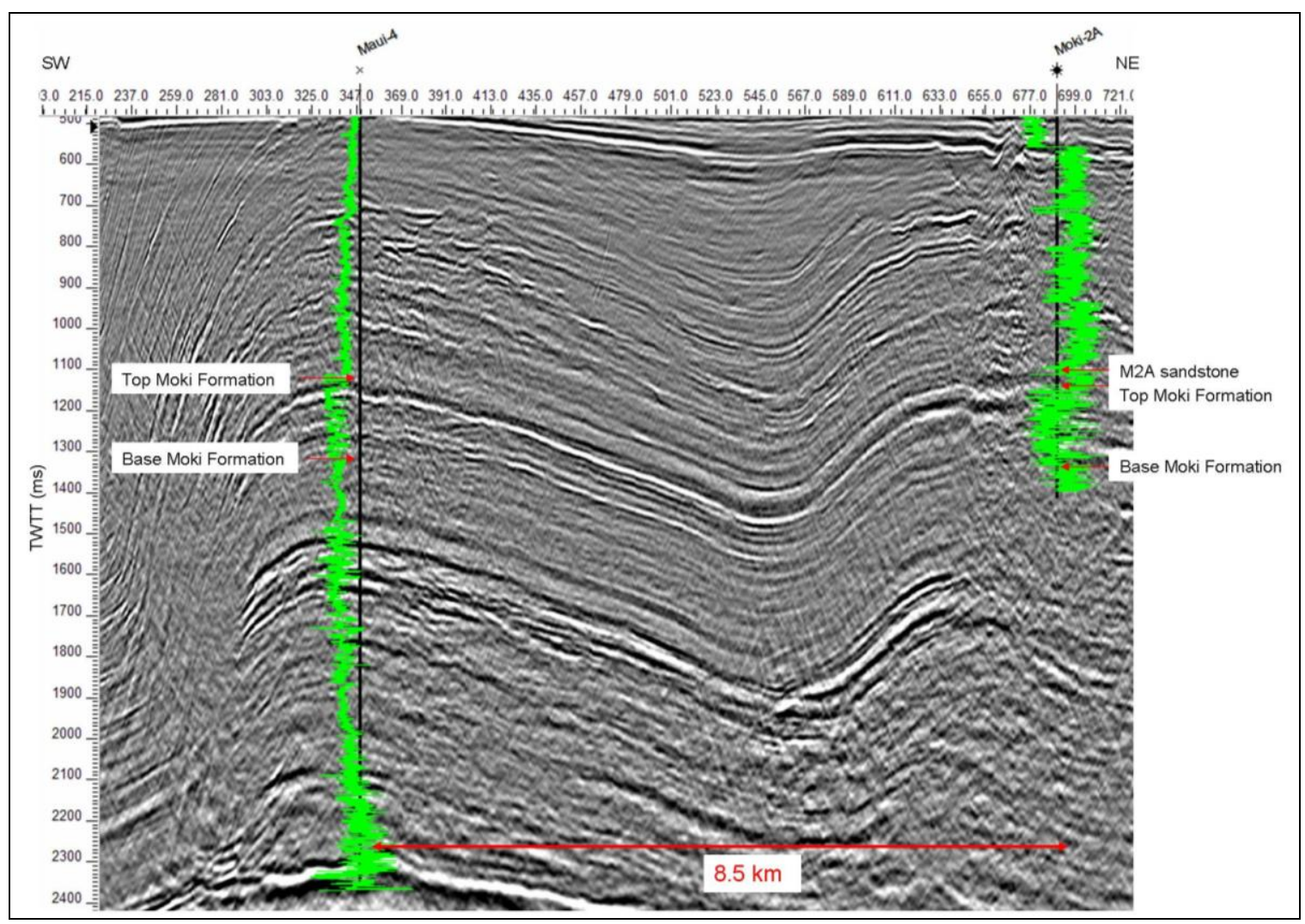

Figure 3.2: Uninterpreted seismic line ct $95-12$ through Maui-4 and Moki-2A (location of line is shown in

Figure 3.1). Gamma ray logs are superimposed in green. Note the typical high amplitude seismic response of the top of the Moki Formation, which decreases downwards. Also note, at Moki-2A the M2A Sandstone above the Moki Formation corresponds to a high amplitude reflector, which fades towards Maui-4.

\section{Near base Moki Formation}

Reflectors of the Moki Formation generally show decreased amplitude with depth so that the base Moki Formation horizon was picked as a low to very low amplitude reflector that is non-distinct from the underlying mudstone of the Manganui Formation (see also Dauzacker et al., 1996; Yang, 1996). This horizon was picked with less confidence than the top Moki Formation. 


\section{Top Sl/Sw Sandstone}

The top of the S1/Sw Sandstone was interpreted to confirm that this unit is a distinct sandstone body from the Moki Formation. The top of the Sl/Sw Sandstone was interpreted as a moderate to high amplitude, generally continuous reflector with moderate to high amplitude underlying reflectors (Figure 3.3). This unit is frequently interrupted by large channels, which caused difficulties in seismic mapping, but nonetheless, the top S1/Sw Sandstone horizon was picked with good confidence through the Maui Field and the northwest of the study area. In other areas the reflector package is lower amplitude and less continuous so the top Sl/Sw Sandstone Equivalent was picked with less confidence.

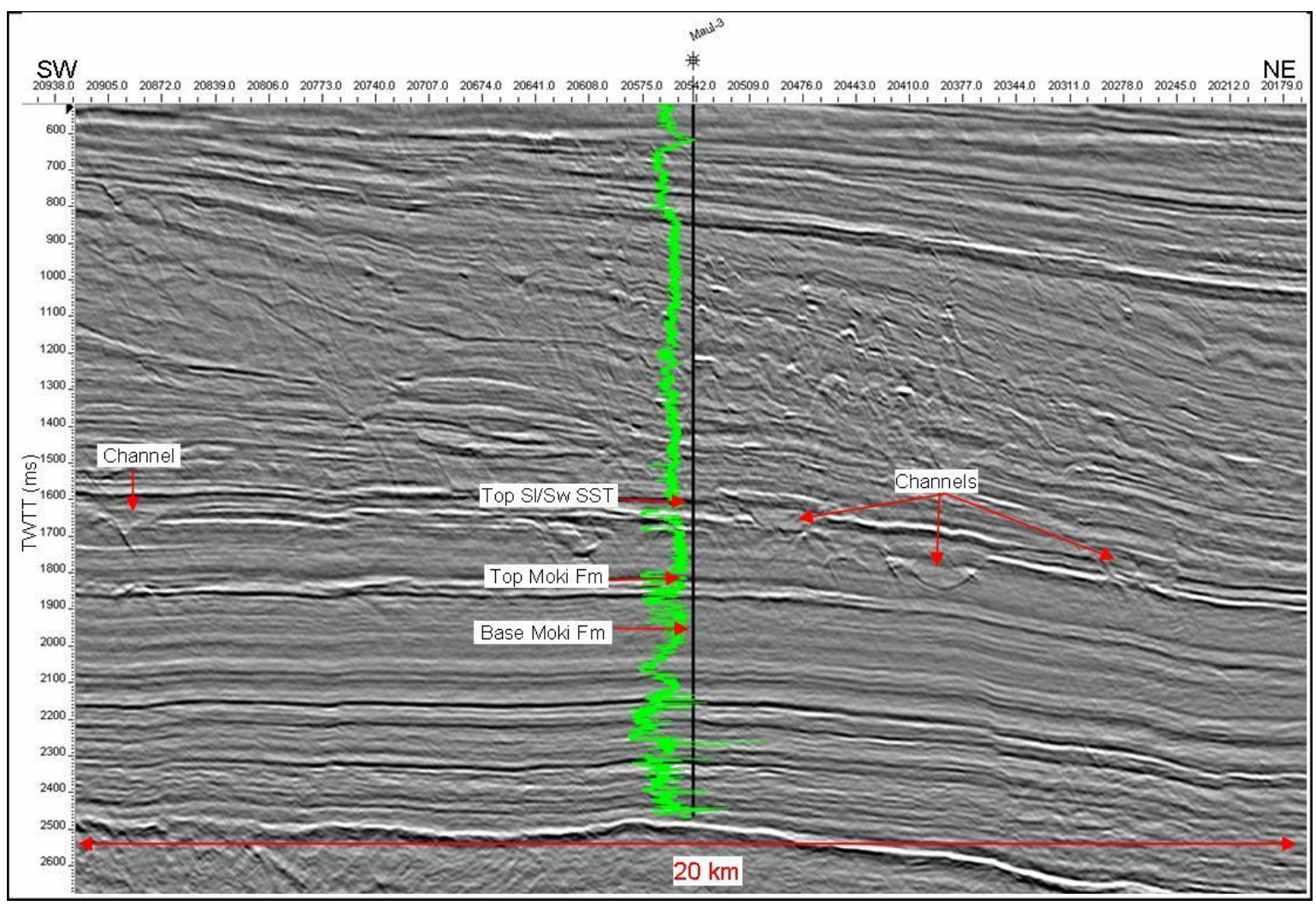

Figure 3.3: Uninterpreted seismic line 86ma-103 through Maui-3 (seismic line location shown in Figure

3.1). Gamma ray log is superimposed in green. The typical seismic character of the $\mathrm{S} 1 / \mathrm{Sw}$ Sandstone consists high amplitude, semi-continuous reflectors with numerous identifiable channels of different ages. The stratigraphically lower Moki Formation is also shown with its high amplitude upper reflectors. Note that the gamma ray log shows fewer sandstone beds (shown on the gamma ray log as a move to the left) in the Sl/Sw Sandstone than the Moki Formation.

\section{Stage boundaries}

The three stage boundaries (near top Altonian, near top Clifdenian and near top Lillburnian) were defined by biostratigraphy data at each well. Due to the coarse biostratigraphic sample spacing the stage boundaries are often poorly defined. Thus, correlating the stage boundaries between wells was problematic and the interpreted seismic 
horizons simply represent approximations of the stage boundaries. For example, Maui-4 has an anomalously thick Clifdenian section that does not correlate with the Moki-Maari area or North Tasman-1. No evidence for progradation was seen in any direction, no faulting observed between these wells and no significant unconformities were identified to allow for an increased thickness of Clifdenian-aged sedimentation at Maui-4. In cases like this, the anomalous sediment thickness is therefore most likely due to problems with stage boundary identification rather than actual variations in sediment thickness. In addition, no clear marker was identified on seismic that could represent these approximate stage boundaries, so these horizons were picked with low confidence.

\subsection{Results and discussion}

\subsubsection{Regional structure}

The study area covers the Southern Inversion Zone and parts of the Western Stable Platform; structure at top Moki Formation level is shown in Figure 3.4. Most of the structure is focused within the Southern Inversion Zone with some faults having large offsets of more than $1000 \mathrm{~ms}$ with a predominant reverse sense of slip at Mid Miocene level. Inverted grabens and half-grabens form a north-south trend through the centre of the area on which most of the wells have been drilled, including the Maui and Maari fields. The Cape Egmont Fault (Figure 3.5) has undergone many reversals in motion through time; during the Mid to Late Miocene it was active as a reverse fault, downthrown to the northwest (e.g. King and Thrasher, 1996; Baur et al., 2008b). To the east of the central trend of inverted grabens and half-grabens is the Toru Trough, where the Moki Formation Equivalent is more than $3000 \mathrm{~ms}$ deep. Structural inversion appears to have been particularly prevalent in the south of the study area. Here a significant south-dipping, angular unconformity truncates Miocene sediments on the structural highs (e.g. those drilled by Surville-1, Motueka-1, Tasman-1, Fresne-1 and Cape Farewell-1). Thick Miocene sediment is present in the adjacent troughs; unfortunately, the age and lithology of this sediment is poorly constrained due to the inability to correlate horizons from the wells drilled on the structural highs. Mid Miocene sediments are largely undeformed on the Western Stable Platform. 


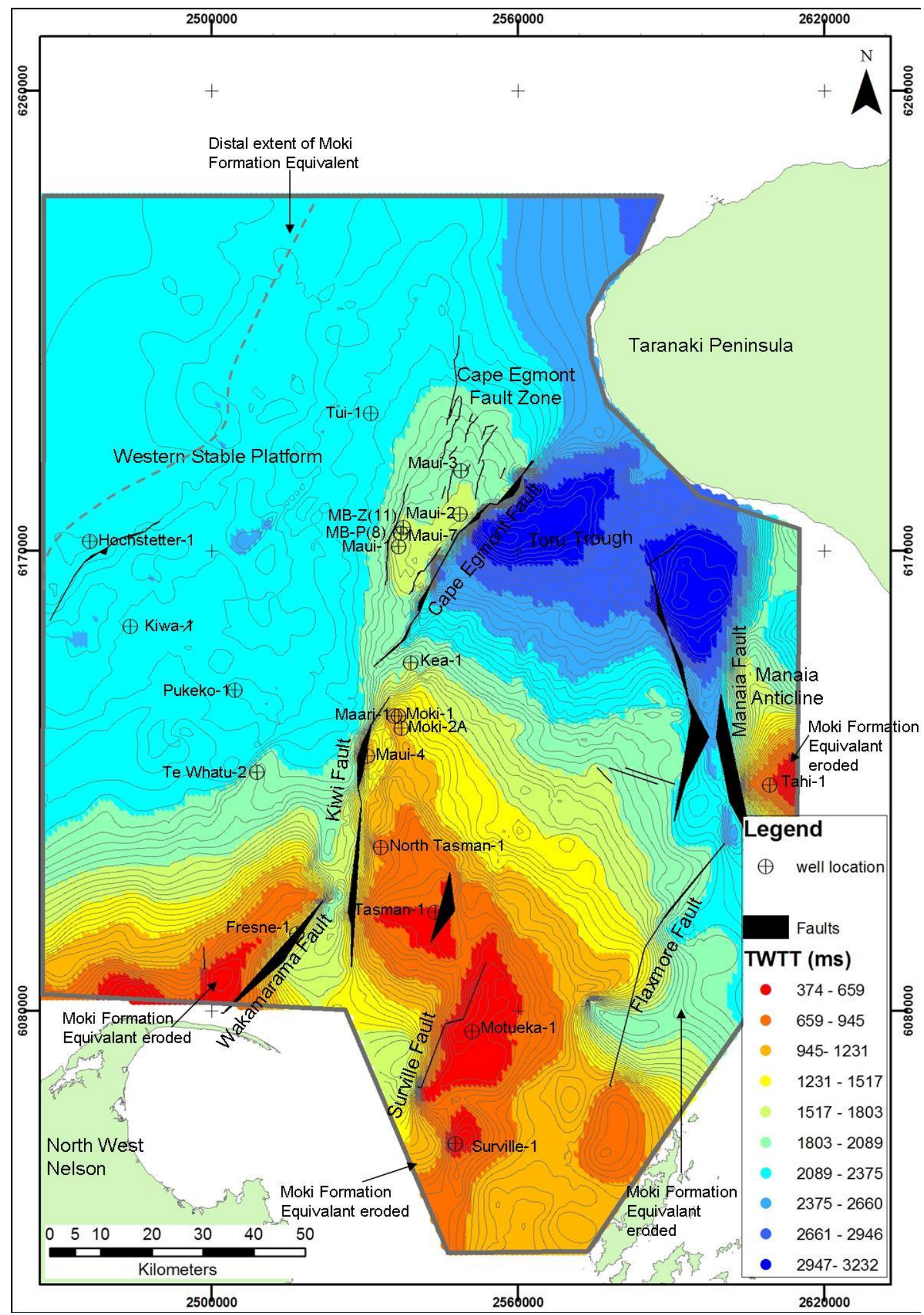

Figure 3.4: Map of the study area showing the present-day structure of the top Moki Formation and its equivalents in Two Way Travel Time (TWTT). Red is structurally high 500 ms, blue is structurally low around $\sim 3000 \mathrm{~ms}$; contour spacing is $50 \mathrm{~ms}$. Note that a Late Miocene-Pliocene unconformity has stripped off the Mid Miocene sediments on the highs drilled by Cape Farewell-1, Cook-1, and Tahi-1 wells and the apparent structure on the map at these locations are artefacts of the interpolation method used for gridding. The distal extent of the Moki Formation is shown by the grey-dashed line in the northwest of the area; again, the apparent depths are interpolation artefacts. Most of the wells drilled are located on structural highs, with only a few, widely spaced wells on the Western Stable Platform and no wells drilled in the Toru Trough. The large offsets on the faults (more than $1000 \mathrm{~ms}$ in some cases) pose difficulties for seismic interpretation. 
Most of the structural deformation within the study area appears to have occurred after deposition of the Moki Formation as shown by uniform offsets across faults and minimal thickness variations over structural highs with a few notable exceptions. Palaeobathymetry data from Kupe wells suggest the Manaia Fault was active during the Mid Miocene uplifting its north-plunging eastern block to shelfal depths (e.g. King and Thrasher, 1996). Further south along the Manaia Anticline at Tahi-1, any Miocene sedimentation was subsequently removed entirely. Seismic interpretation across the Cape Egmont Fault shows syn-sedimentary faulting patterns, illustrated by variable offset of seismic horizons, which suggest it was active as a reverse fault up-thrown to the southeast (this study; King and Thrasher, 1996), although structural restorations suggest the offset would have been minor in the Mid Miocene (Baur et al. 2008b). Dauzacker et al. (1996) showed from isopach maps that the Maui-4 and Moki-Maari structural highs may have started to rise between deposition of the Moki Formation and the M2A sand.

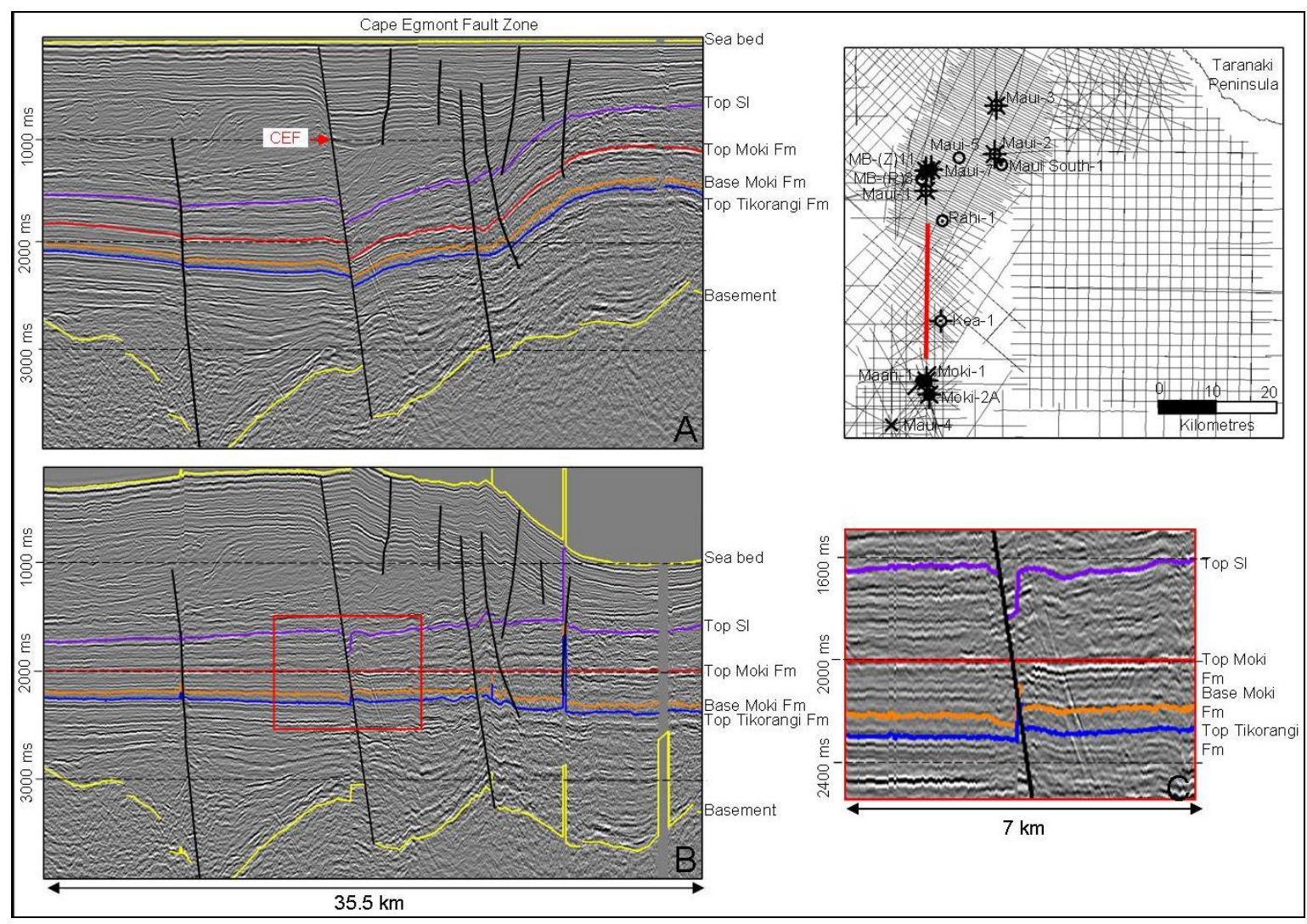

Figure 3.5: (A) Interpreted seismic line tnz81-618 (indicated by red line on map) showing the Cape Egmont Fault (CEF) and neighbouring faults (B) same interpreted line flattened on top Moki Formation. Red box indicates zoom-in on the Moki Formation at the Cape Egmont Fault (C) showing a slight reverse offset of the Base Moki Formation and Top Tikorangi Formation, implying the fault was active as a reverse fault at the time of deposition of the Top Moki Formation.

The degree of post-depositional deformation and erosion significantly reduced confidence in seismic interpretation. For example, correlating across major faults onto the Western 
Stable Platform was particularly difficult, especially as the Moki Formation is not clearly defined by either seismic or wireline log character in this area. As a result, several different top Moki Formation interpretations proved possible. Furthermore, extending seismic interpretation across faults into the Toru Trough was difficult, made worse by the absence of wells and the incoherent nature of seismic reflectors through much of this area.

\subsubsection{Mid Miocene seismic stratigraphy}

Figure 3.6 and Figure 3.7 show a number of changes in seismic character from south to north and from east to west respectively, reflecting changes in lithology and stratification and thus the depositional environment. These observations are briefly noted below and are discussed in more detail in Chapter 4.

\section{Altonian - Mid Lillburnian (Moki Formation and equivalents)}

Prograding clinoforms are evident in the south on line NS-1 (Figure 3.6B) and in the east on line EW-2 (Figure 3.7B). Palaeobathymetry data from the Motueka-1 well, which penetrated the clinoforms, show a shallowing from mid-slope to outer-shelf from the Late Altonian to the Early Lillburnian (Scott, 1991), suggesting the clinoforms could represent a transition from slope to shelf (Figure 3.6B). The clinoforms in the east of line EW-2 (Figure 3.7B) are interpreted to be part of the same transition from slope to shelf. Topset reflectors are typically high amplitude, low frequency and continuous whereas the foreset reflectors are often low amplitude and incoherent. Farther to the north and the west, these low amplitude, incoherent reflectors give way to high amplitude, coherent, bottomset reflectors (Figure 3.7C). This seismic character correlates with the sandstone packages of the Moki Formation in the central wells (Figure 3.6C). The high amplitude, bottomset reflectors appear to change amplitude over distance; between closely spaced wells it appears that this amplitude change may be due to changes in lithology (such as the M2A sandstone reflector in Figure 3.2). Through the Maui Field, the otherwise continuous reflectors are interrupted by channels, which are filled by either low amplitude or variable reflectors (Figure 3.6D). Farther northward and westward again, reflectors fade in amplitude, thin and merge so that the entire sequence thins onto the basin floor (Figure 3.7D). 


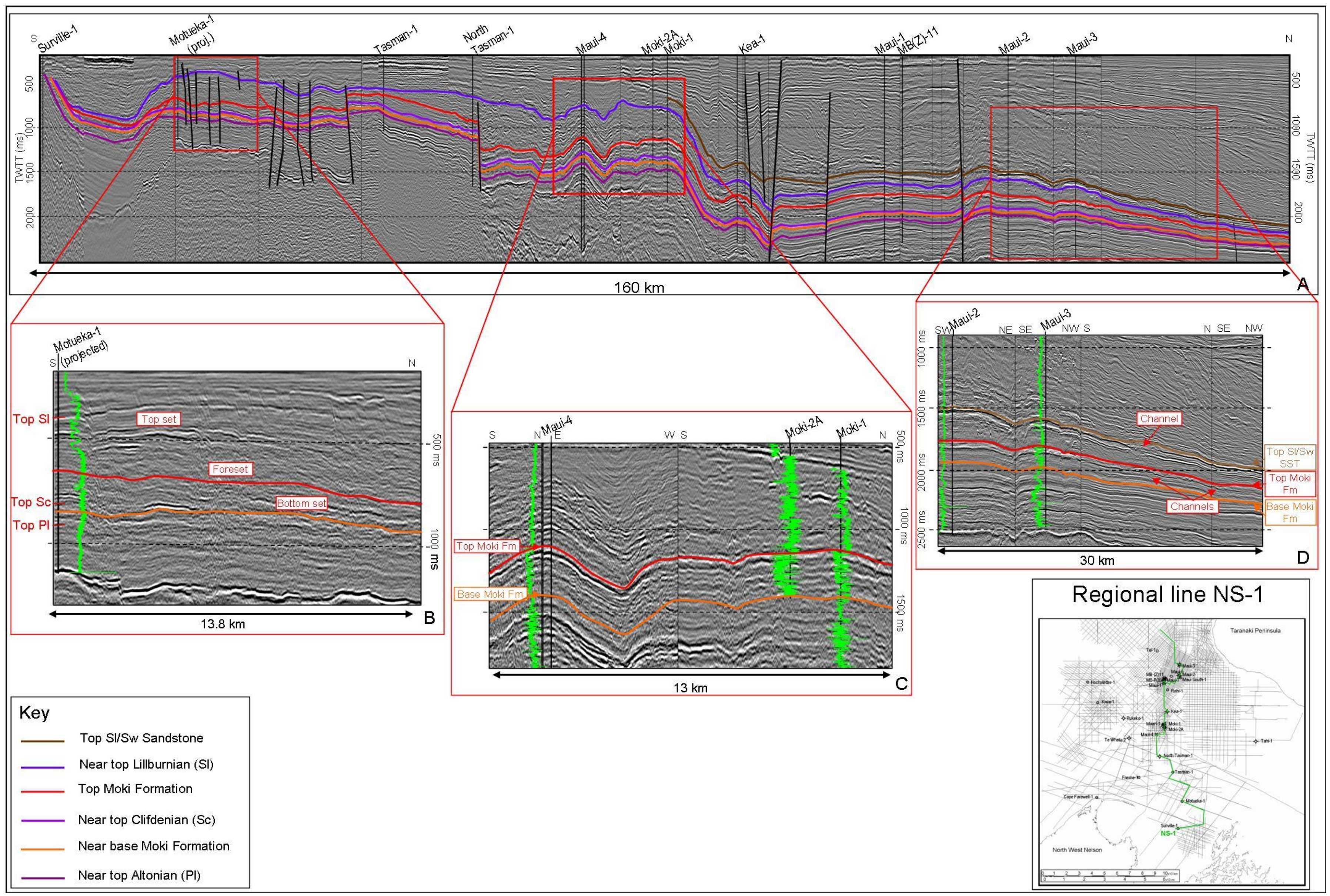

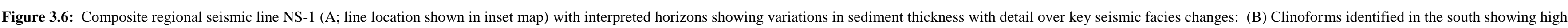
amplitude topsets and bottomsets and low amplitude foresets (C) typical high-amplitude, coherent seismic character of the Moki Formation and (D) channelisation and northward thinning of Mid Miocene sediments. 


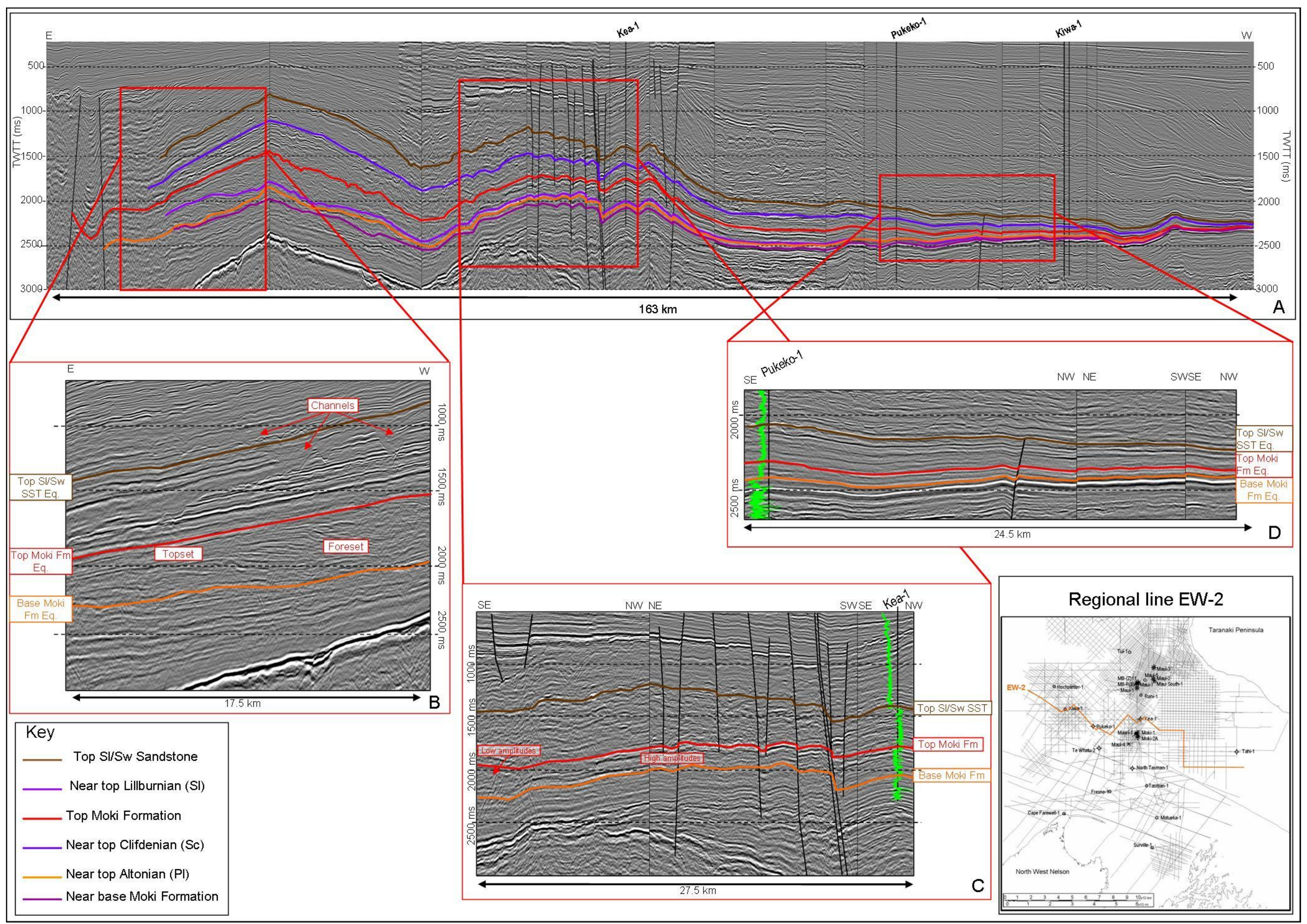

Figure 3.7: Composite regional seismic line EW-2 (A; line location shown in inset map) with interpreted horizons showing variations in sediment thickness with detail over key seismic facies changes: (B) Clinoforms identified in the east (C) marked change in seismic facies in the Moki Formation from low amplitude reflectors to continuous high amplitude reflectors which correspond to the blocky gamma ray log motif in Kea-1 and (D) thinning, and fading reflectors toward the west. 
Isopachs of the Moki Formation (Figure 3.8) show that the main body of the fan system is located through the centre of the study area and trends roughly south-north. The thickest parts of the Moki Formation are located in the centre of the area and the formation thins to the west and the north. The Moki Formation Equivalent is very thin at Kiwa-1; gamma ray logs show it is dominantly comprised of mudstone with fine interbeds of sandstone.

Seismic correlation suggests the Moki Formation Equivalent does not reach as far northwest as Hochstetter-1. This is supported by the Hochstetter-1 well biostratigraphy, which shows that only a thin package of Lillburnian-aged mudstone was intersected in this well. Accordingly, the northwestern extent of the Moki fan system is defined.

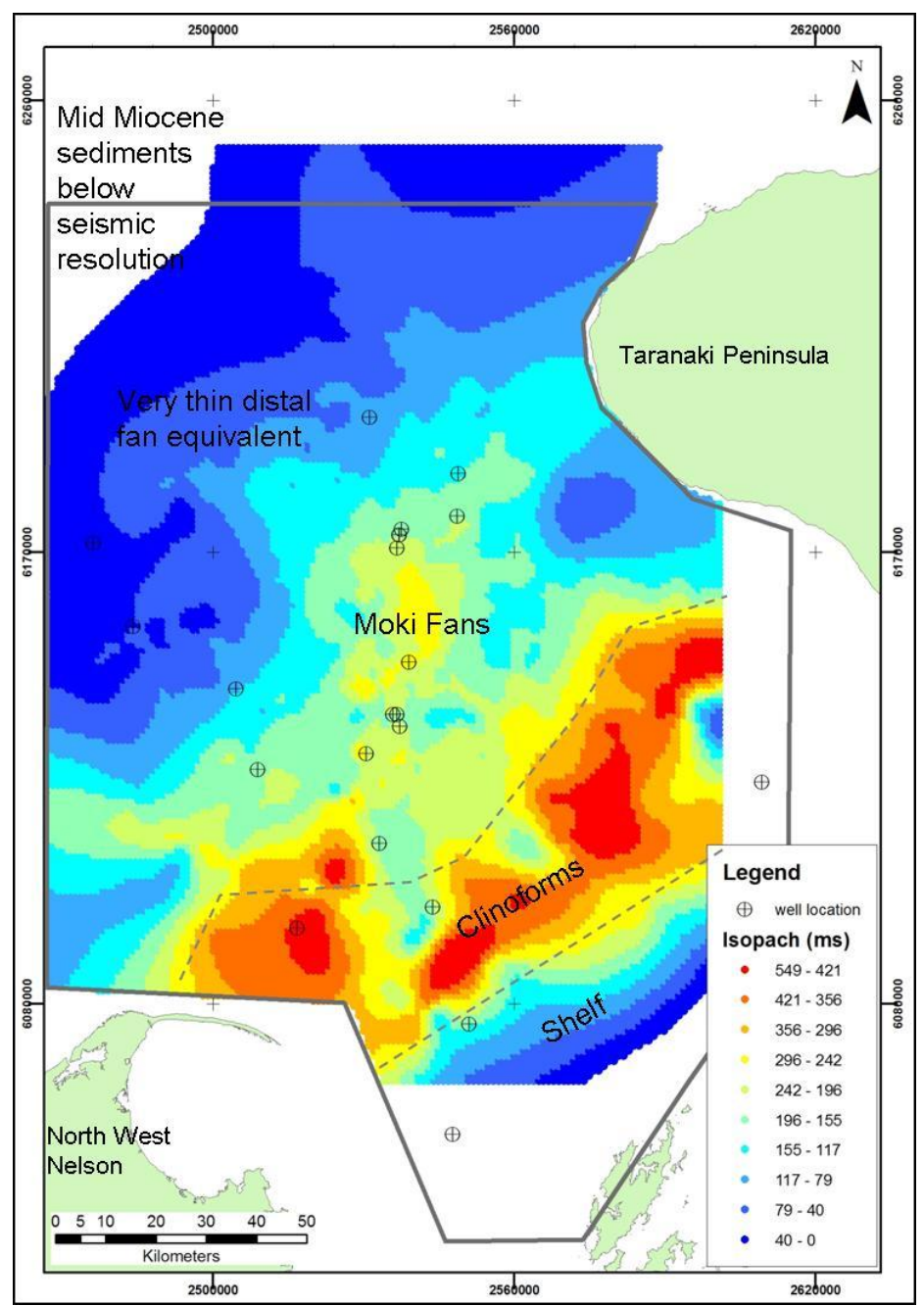

Figure 3.8: TWTT isopach map of the Moki Formation and its time equivalents. The coeval shelf is represented as a thin package of sediment in the southeast behind very thick clinoforms. The fans of the Moki Formation are present through the centre of the study area and thin towards the north and west.

\section{Latest Lillburnian / Waiauan (Sl/Sw Sandstone and equivalents)}

The S1/Sw Sandstone corresponds to typically high amplitude reflectors, which are often as high amplitude as the reflectors of the Moki Formation. The S1/Sw Sandstone reflectors are best developed, that is high amplitude and continuous, to the northwest of the Maui 
Field (Figure 3.6D). Here, the sandstone unit is heavily incised with large, deep channels. To the south, the unit is represented by reflectors that fade in amplitude over relatively short distances; sandstone packages are not correlateable between wells. Seismic interpretation confirmed that this sandstone unit is indeed distinct from the Moki Formation, though the reflectors do appear to merge towards the northwest as the entire Mid Miocene sediment thins. Figure 3.7B shows the coeval shelf of the Sl/Sw sandstone is incised by very large channels. These channels were mapped by Bushe et al. (2008) and are here interpreted to have fed the Sl/Sw Sandstone fans.

\subsection{Summary}

Regional seismic correlation has defined the stratigraphic and spatial extent of the Moki Formation, confirming that the $\mathrm{Sl} / \mathrm{Sw}$ sandstone is a distinct package of sandstones from the Moki Formation. The Moki Formation trends south-north and is thickest through the centre of the study area, thinning to the north and west. The Sl/Sw Sandstone covers a relatively small area and is best developed to the northwest of the Maui Field. Several areas were highlighted for further detailed seismic facies work. These were:

1. clinoforms in the south and east of the study area;

2. amplitude variations in central areas which may suggest lithology change;

3. thinning, merging and downlap of reflectors in the west and north of the study area;

4. fan channels in the Maui area and to the northwest, particularly within the $\mathrm{Sl} / \mathrm{Sw}$ Sandstone, and

5. possible feeder channels on the coeval shelf of the S1/Sw Sandstone.

These features were studied in more detail and are discussed further in Chapter 4. 


\subsection{Seismic facies interpretation}

\subsection{Introduction}

Seismic stratigraphy and seismic facies analysis were developed by the oil and gas industry within the last 50 years. These interpretation concepts have since become a valuable tool for the development of depositional models for sub-surface formations, and thus the prediction of sandstone bodies, which potentially contain hydrocarbon accumulations. These concepts are simple and elegant and are widely used and applied in both the oil industry and academia.

Within the study area, regional seismic interpretation (Chapter 3) has highlighted areas of key seismic facies changes including clinoforms; thinning, merging and downlap of reflectors; amplitude variations, and channels. This chapter discusses further detailed work in these areas to identify, locate and describe the seismic facies of the Mid Miocene interval, thus providing key constraints for the palaeogeography through this time.

\subsection{Principles of seismic sequence and facies analysis}

Seismic reflections are generated by acoustic impedance contrasts of physical surfaces in sub-surface rocks such as stratal boundaries (bedding surfaces) or unconformities where the underlying layer is more consolidated (Vail and Michum, 1977). Seismic stratigraphy uses the patterns of these seismic reflections to identify depositional sequences, to predict the lithology and stratification from seismic facies in conjunction with other data, to determine depositional environments and to analyse relative changes in sea level by applying established depositional models. Interpretation of strata from seismic data involves three stages: seismic sequence analysis, seismic facies analysis and the subsequent interpretation of depositional environments and lithofacies (Vail and Mitchum, 1977) and is outlined in detail in the American Association of Petroleum Geologists Memoir 26.

First, seismic sequence analysis identifies depositional sequences, defined by Mitchum (1977) as "a stratigraphic unit composed of a relatively conformable succession of genetically related strata and bounded at its top and base by unconformities or their correlative conformities". Because depositional sequences consist of genetically related strata in a chronostratigraphic framework, they provide an ideal tool for stratigraphic 
analysis (Vail and Mitchum, 1977). These are primarily interpreted as being caused by fluctuations in relative sea level and changes in sediment supply (Boggs, 2001). Sequence boundaries are unconformities or discontinuity surfaces, which are identified by recognising terminations on the surface. The terminations are named by their relationship with the sequence boundary as illustrated in Figure 4.1.

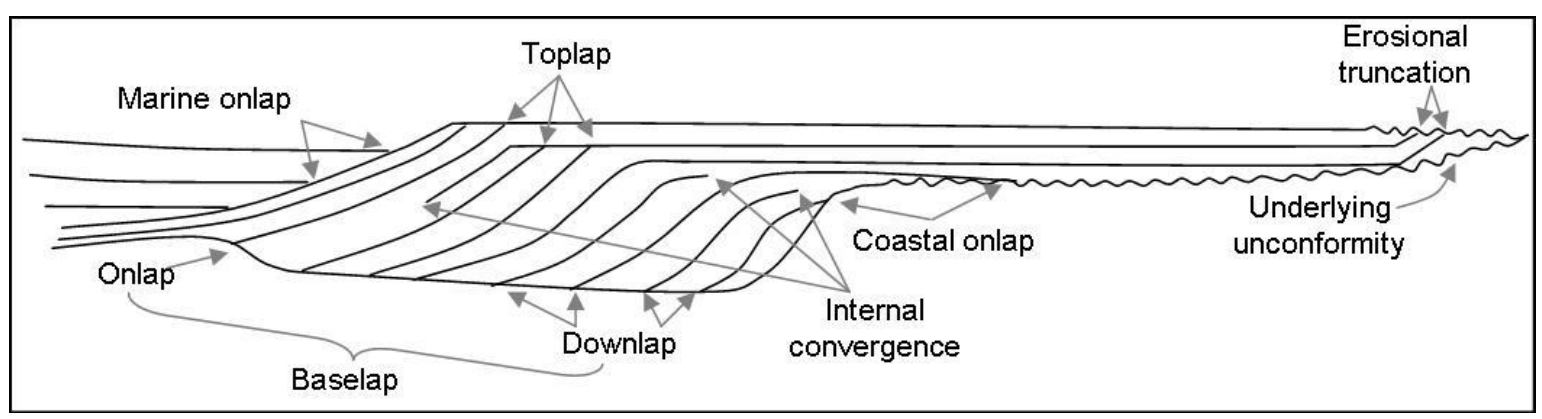

Figure 4.1: Types of reflector terminations that define unconformable boundaries in a prograding depositional system. Modified after Mitchum et al. (1977).

Secondly, seismic facies analysis examines smaller reflection units within depositional sequences that are interpreted to be the seismic responses of the gross lithology and stratification. Seismic facies are described on their reflection configuration, continuity, amplitude, frequency and interval velocity and external form (Mitchum et al., 1977). Reflector configuration is interpreted to be affected by the nature of stratification; some common reflector configurations and their geological interpretations are shown in Figure 4.2. Reflector continuity depends on the continuity of the acoustic impedance contrast along bedding or unconformity surfaces. Reflection amplitude increases with acoustic impedance contrast and is therefore often associated with boundaries between differing lithologies or cementation. Frequency is dependant on the thickness of acoustic impedance boundaries, and the interval velocity is dependant on rock density. The external (or threedimensional) form of reflecting units is determined by mapping the seismic facies groups between seismic lines, and by observing the relationship between neighbouring seismic facies. These 3D geometries include sheets, sheet drapes, wedges, banks, lenses and channel fills (Figure 4.2). 


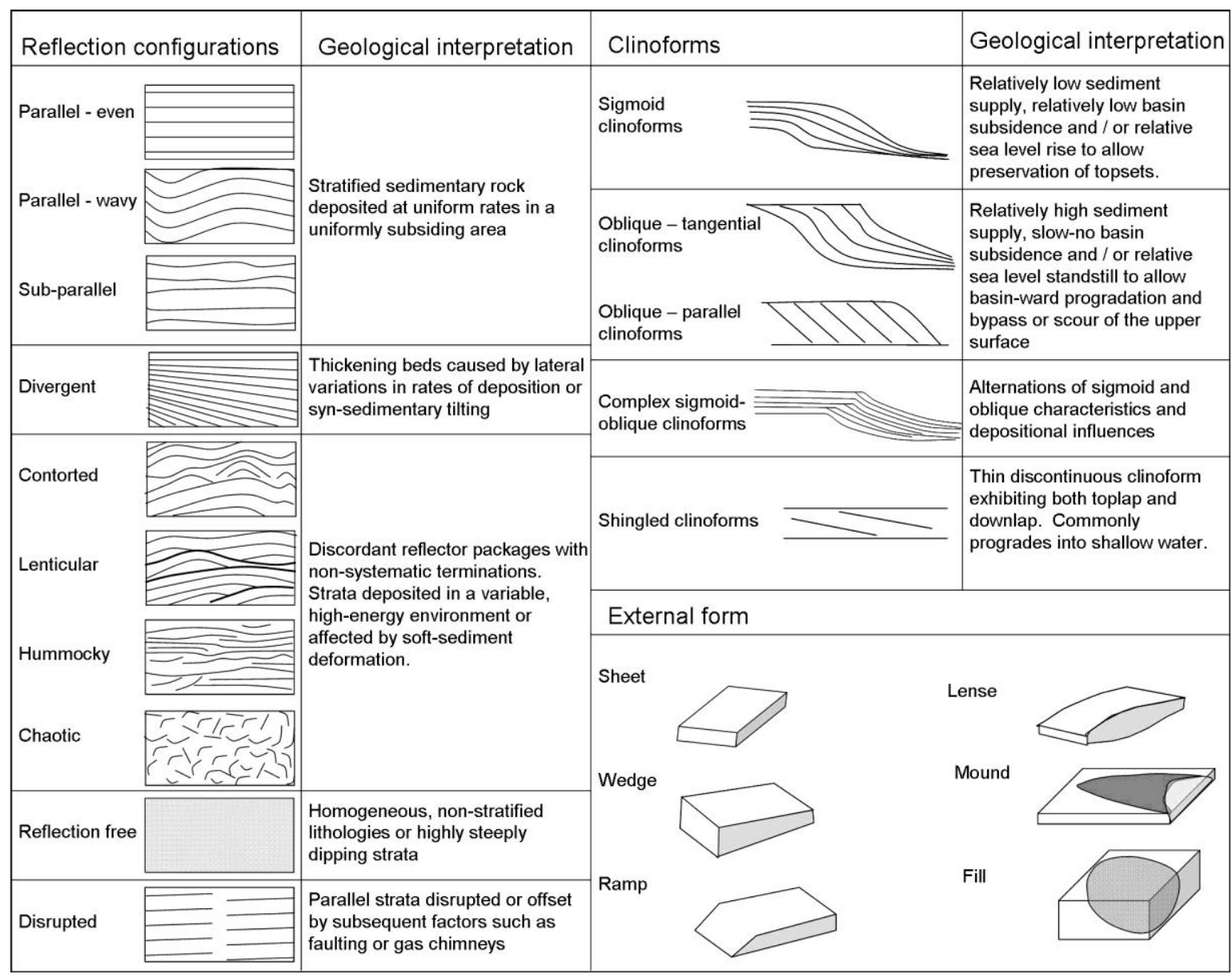

Figure 4.2: Configuration of typical reflection patterns, their geological interpretations and external forms. Modified after Mitchum et al. (1977)

Finally, an interpretation of the depositional environment may be made from the seismic facies characteristics and relationships with neighbouring seismic facies, comparison with established depositional models and other non-seismic information such as well data and outcrops.

Within the last 10 to 15 years, seismic quality, technology and computer processing power has advanced significantly to allow the production of high-resolution images from 3D seismic datasets by application of various attributes of seismic reflection including amplitude, semblance (or coherence), frequency, curvature, dip azimuth (seismic geomorphology, e.g. Posamentier et al., 2007). From this, spectacular imagery of geomorphic features can be produced, providing detailed information of changes in geomorphology through time.

The techniques described above were used to analyse the seismic facies of the Mid Miocene sediments within the study area in order to identify key features that are indicative of the Moki Formation deposition. 


\subsection{Mid Miocene seismic facies}

Sandstones of the central Moki Formation fan system are typically represented on seismic profiles by high amplitude, coherent reflector packages (Figure 3.2). These reflectors are usually sub-parallel with one another and reflectors within the surrounding Manganui Formation. This section describes variations from this continuous, sub-parallel seismic character and provides an interpretation of each facies' deposition.

\subsubsection{Clinoforms and feeder channels}

In the southeast of the study area, prograding clinoforms were identified on several seismic lines (Figure 4.3). These clinoforms have a complex sigmoid-oblique pattern, with a significant amount of aggradation and progradation. The flat-lying top reflectors (undaform of Rich, 1951) are typically characterised by a series of high amplitude, concordant reflectors, which become discordant towards the clinoform. By contrast, the clinoform is characterised by low amplitude, incoherent reflector packages. Where the clinoform is well imaged, reflectors have a hummocky character and thin towards the top and base of the clinoform. The seismic character of the undaform and clinoform is different on some lines, which show similar amplitudes between the undaform and the clinoform (e.g. Figure 4.3 A-A'). This is probably due to the orientation of the seismic line with respect to the orientation of the clinoforms. The seismic lines that show the clinoforms are highlighted in red in Figure 4.3; collectively these lines display a broadly arcuate southwest to northeast trend in the southeastern corner of the study area. Seismic correlation from wells proved difficult due to the incoherent character of the uppermost slope sediments and poor well control, particularly on the eastern margin. 


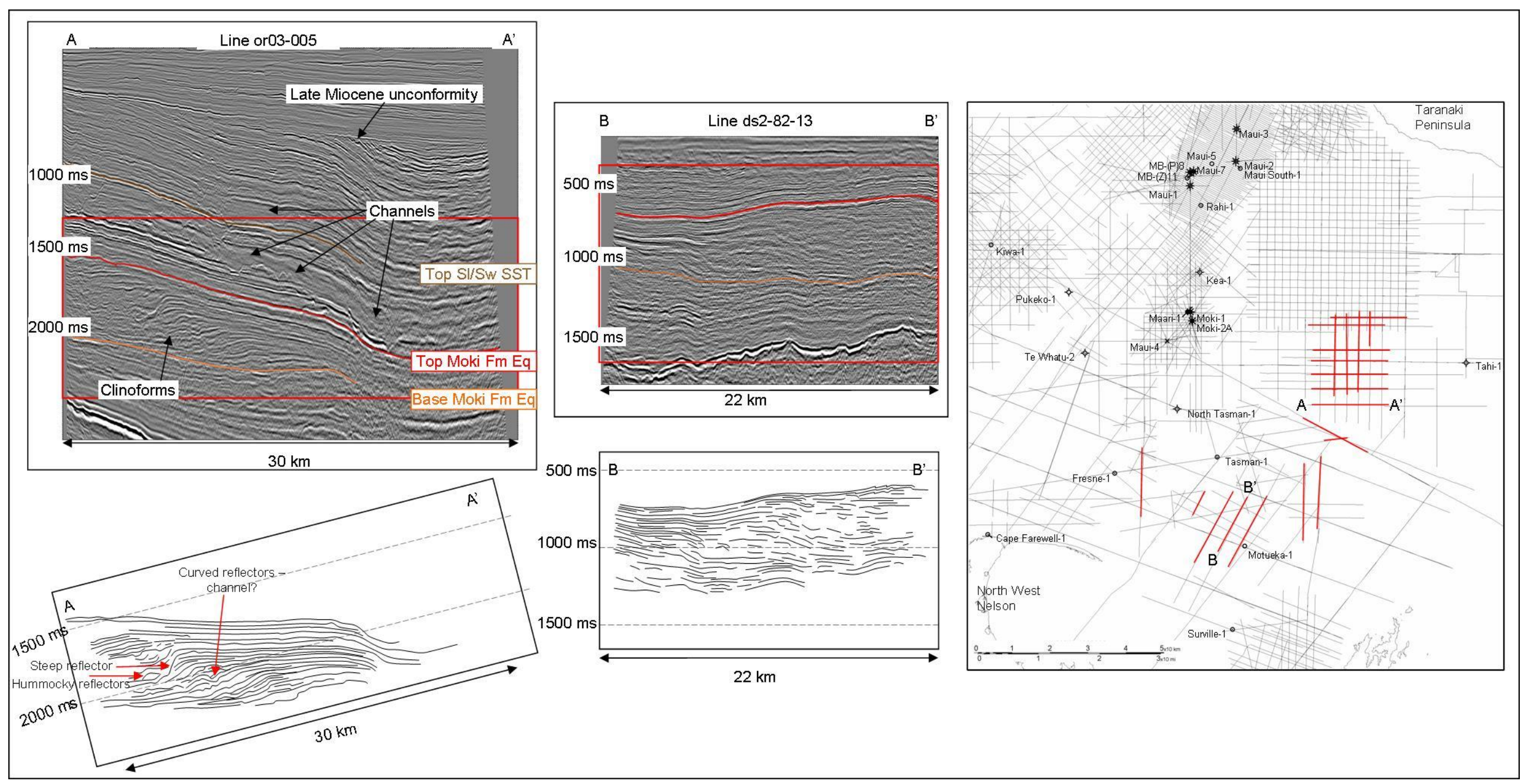

Figure 4.3: Seismic line or03-005 (A-A' on map) showing clinoforms, channels, and the late Miocene unconformity with a simplified line drawing (below) of the Moki Formation

Equivalent interval tilted $20^{\circ}$ anticlockwise to remove post-depositional tilting. Curved reflectors are possibly channel features and steep reflectors with hummocky reflectors at base may be evidence for mass wasting of the uppermost slope. Seismic line ds2-82-13 (B-B' on map) showing clinoforms with characteristic high amplitude shelf and low amplitude slope reflectors and a simplified line drawing (below) of the clinoforms. Map shows the seismic lines (in red) in which clinoforms are mapped. 
The clinoforms were intersected by the Motueka-1 well (Figure 4.4); palaeobathymetry data from foraminifera from the well show the site was at mid-slope depths during the Altonian and shallowed to mid- to outer-shelf depths by the Lillburnian (Scott, 1991). However, there is not an exact match between the palaeobathymetry determined by foraminifera and the seismic facies. For example, palaeontological data suggests the site is at shelf depths possibly as early as Clifdenian (at $1025 \mathrm{~m}$ bdf) but certainly by the Early Lillburnian (at $750 \mathrm{~m}$ bdf). By contrast, seismic facies analysis suggests the site is not at shelf depths until Late Lillburnian (at $\sim 600 \mathrm{~m}$ bdf). The differences between may be caused by several factors: (1) Motueka-1 is projected onto the seismic line (700 m away) and lateral variation may play a part.; (2) the time-depth curve for Motueka-1 may be incorrect; (3) the coarse sample spacing, downhole mixing and / or absence of diagnostic fauna would have increased error in bathymetry estimates. Nonetheless, these clinoforms are considered here to represent the coeval shelf-slope break during deposition of the Moki Formation. Gamma ray and sonic logs from Motueka-1 (Figure 4.4) show the highamplitude flat-lying reflectors interpreted as shelfal, to represent dense mudstones and are therefore thought to be produced by condensed layers, which probably formed when the shelf was starved of sediment during relative sea level high stands. At Motueka-1, the dipping low-amplitude, incoherent reflectors correspond to mudstones implying this seismic facies represent weakly stratified slope mudstones.

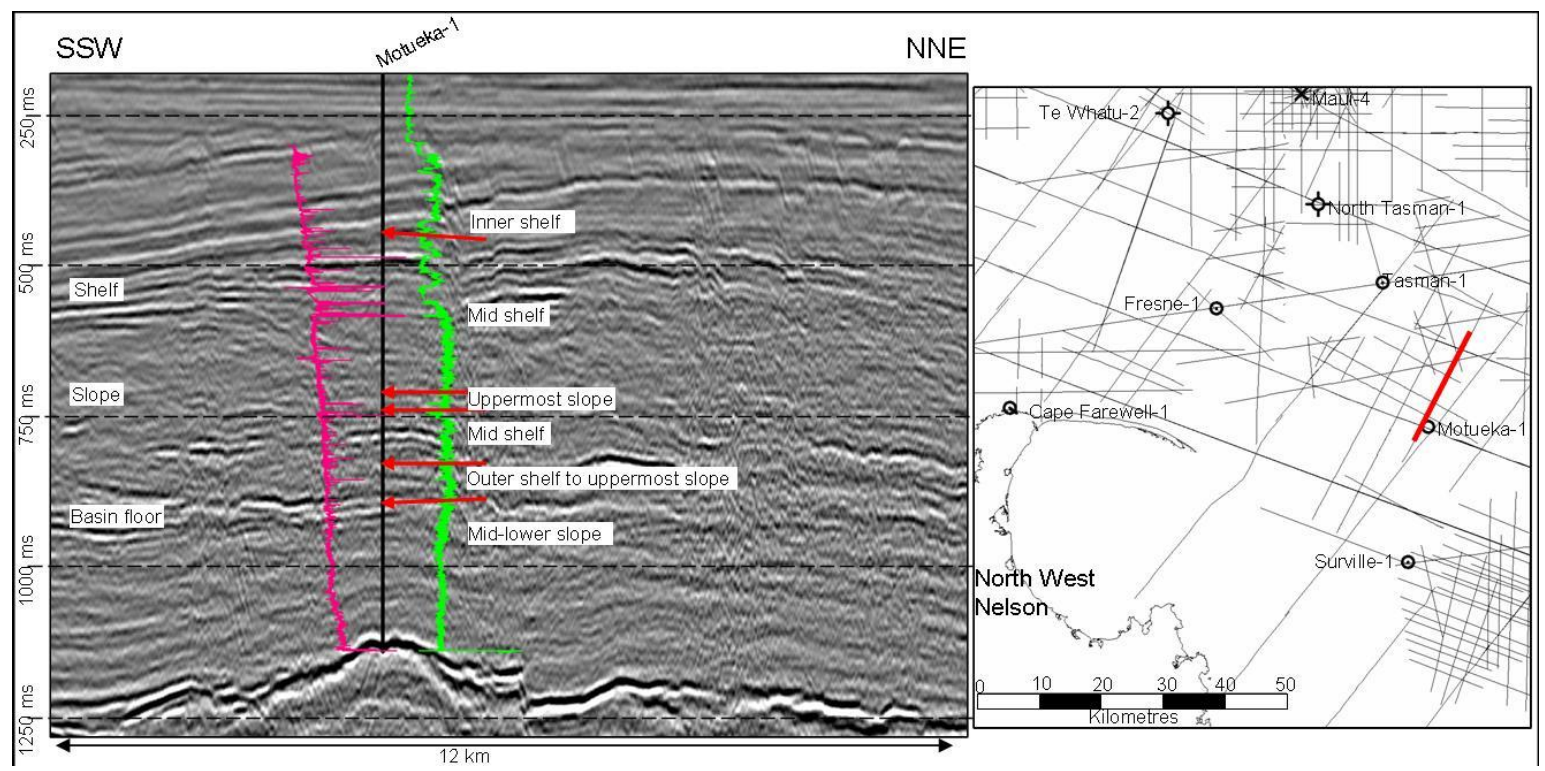

Figure 4.4: Seismic line s89-05 (line location shown on map) with Motueka-1 projected ( 700m) showing clinoforms. Hard beds are shown on the sonic $\log$ (pink) corresponding to high amplitude undaform reflectors; gamma ray log is shown in green. On the left are bathymetry interpretations from seismic facies and in the centre water depths from foraminifera (arrows indicate changes in depths); these interpretations do not match exactly (see text). The clinoforms are interpreted as a transition from slope to shelf. 
Along some seismic lines, possible evidence for mass-wasting was seen as anomalously steep reflectors in the clinoforms with a clustering of hummocky reflectors near the base (see Figure 4.3, line or03-005, 1800 ms). In addition, possible evidence for channelisation was seen as concave reflectors on the clinoforms (see Figure 4.3, line or03005, 2000 ms).

On some of the eastern seismic lines, large, deep channels incise shelfal reflectors in strata interpreted as Upper Lillburnian to Waiauan in age (Figure $4.3 \mathrm{~A}-\mathrm{A}^{\prime}$ ). Thus, this channel system probably fed the fan system of the S1/Sw Sandstone. These channels were mapped by Bushe et al. (2008) as trending north-west and the younger channels appear to migrate across older channels. The channels are generally filled with low amplitude sediment and show lateral accretion.

\subsubsection{Amplitude variations}

The low amplitude, incoherent reflectors at the base of the clinoforms change abruptly into the high amplitude, coherent reflectors typical of the Moki Formation toward the west (Figure 4.5). Through the "hzta82a" survey, this change in seismic character from east to west occurs in the deeper reflectors first, implying a shift of this facies boundary westwards through time. For each reflector, the location of this seismic facies change was marked on each seismic line and traced in map view, showing an approximate north-south orientation (Figure 4.5). The western limit of the high amplitude, coherent facies (Moki Formation) is less marked, with some reflectors fading out over short distances, and others extending far onto the Western Stable Platform (see section 4.3.4). This seismic facies change from low amplitude, incoherent reflector packages to high amplitude, coherent packages is interpreted to be caused by an increase in sandstone content, as indicated by wireline logs, and accordingly, the mapped facies change delineates the eastern margin of the fan system. 


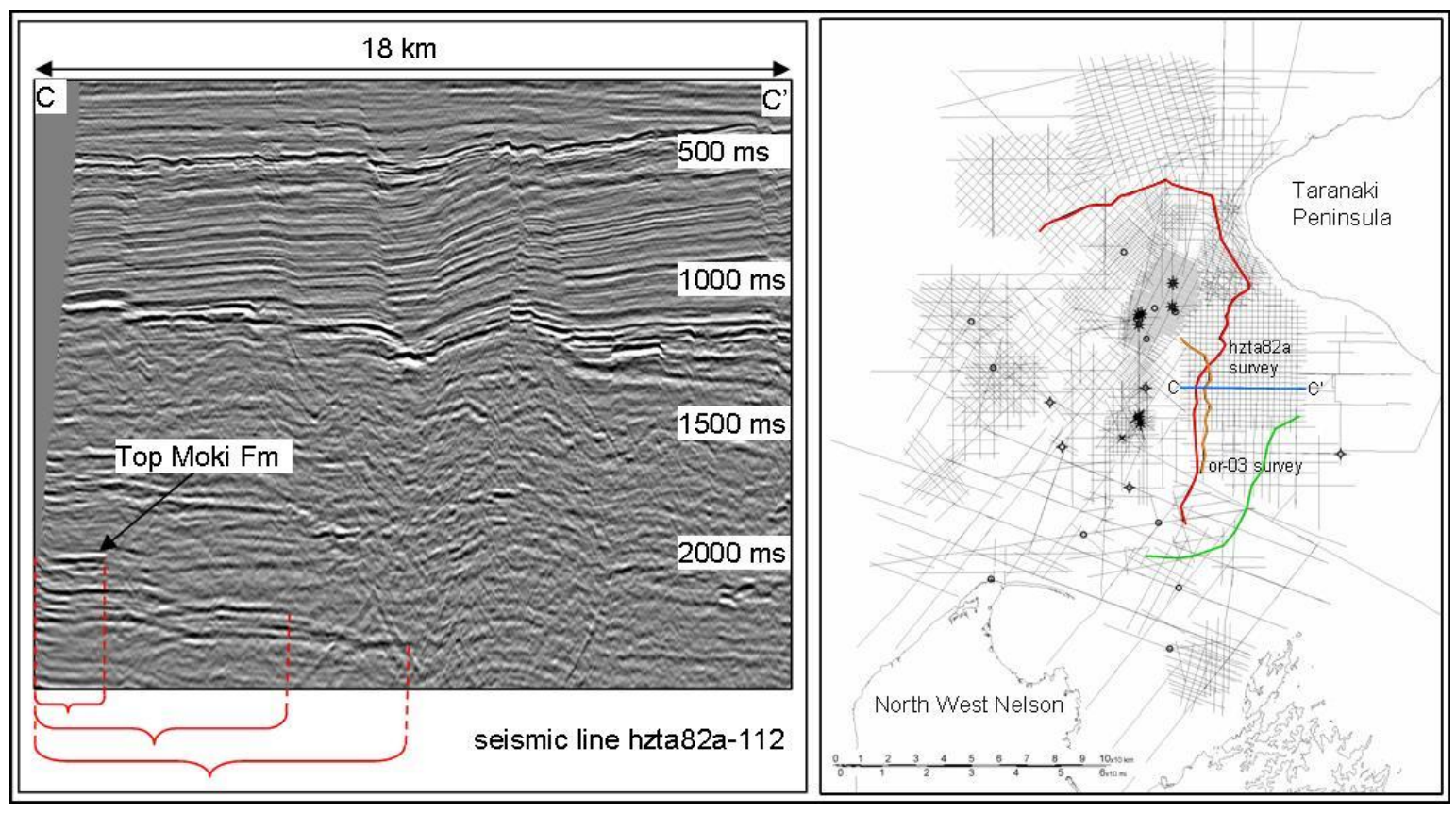

Figure 4.5: (Left) Seismic line hzta82a-112 (C-C' blue line on map) showing the marked change in seismic facies from low amplitude incoherent reflectors to the high amplitude, continuous and sub-parallel reflectors typical of the Moki Formation from east to west as indicated by the brackets. (Right) map showing the location of the change in seismic character along the top Moki Formation (red) and a deeper reflector (orange). The approximate location of the shelf-slope break at top Moki Formation level is shown in green.

Initially, it was uncertain why this eastern limit is so distinctive in comparison with the western extent as nothing was observed in seismic data that may represent a physical barrier to prevent the fan from extending eastward. However, with identification of the shelf-slope break to the east, this eastern limit was probably controlled by the slope gradient.

Furthermore, within the typical Moki Formation seismic facies, individual reflectors change amplitude and thickness over distance, particularly within the Maui-4 and MokiMaari areas. Unfortunately, due to the structure and shallow gas effects blurring seismic data in this region, individual reflectors could not be mapped, even on the Maari-3D seismic data set (this study, see also de Bock et al., 1991; de Bock, 1994). However, from comparison with well logs, the amplitude variations appear to be caused, at least partially, by lithology variations (see also Bussell, 1994) with high amplitudes indicating sandstone and low amplitudes indicating mudstone. This observation provides some indication of fan switching within the central fan system of the Moki Formation.

The Moki Formation exhibits less amplitude variation in the Maui Field than observed in the Moki-Maari area. In general, the lower part of the formation in the Maui Field is continuous, sub-parallel and low amplitude. The top of the Moki Formation produces 
higher and more variable amplitudes than the lower parts of the formation. The top reflector is also moderately channelised (see section 4.3.3). This upwards change in amplitude may suggest a change from outer-fan or outer mid-fan to mid-fan through time. In the Maui B area (southern Maui Field), the top sandstones of the Moki Formation fade toward the north and correlate to mudstones above the Moki Formation in the Maui-3 well.

\subsubsection{Fan channels}

Channels occur on the surface of most sub-marine fans, particularly on the inner and mid fans. Often these channels are relatively shallow and cannot be detected on seismic scales, but may be observed in plan-view by applying various seismic attributes on 3D datasets. Sediments which infill deep channels that can be detected on 2D profiles show a variety of reflection characteristics including chaotic, reflection-free and oblique clinoforms depending on the nature of the infilling sediment.

Channels incised into the Moki Formation were observed throughout the area. Mostly, this was seen as a disruption to the surrounding reflectors with a slight concave reflection curvature. With the present seismic database, it is not possible to correlate these channels between seismic lines. However, through the Maui Field, where data quality is higher in a dense seismic grid, channels were observed near the top of the Moki Formation as incisions through a few reflectors and filled with low reflectivity infills (Figure 4.6A).

Large channels incised into the S1/Sw Sandstone are recognised over the Maui Field and the sunz91 and stos95 lines to the north west of the Maui Field (Figure 4.6B). These channels are several kilometres in width, several hundred milliseconds deep, and become wider and deeper farther to the northwest. They are generally filled with variable amplitude, ordered reflectors, which collectively are lower amplitude than the surrounding reflector package. The channel walls are usually very well defined, sometimes showing several phases of development through lateral migration and / or multi-story development (Figure 4.6). 


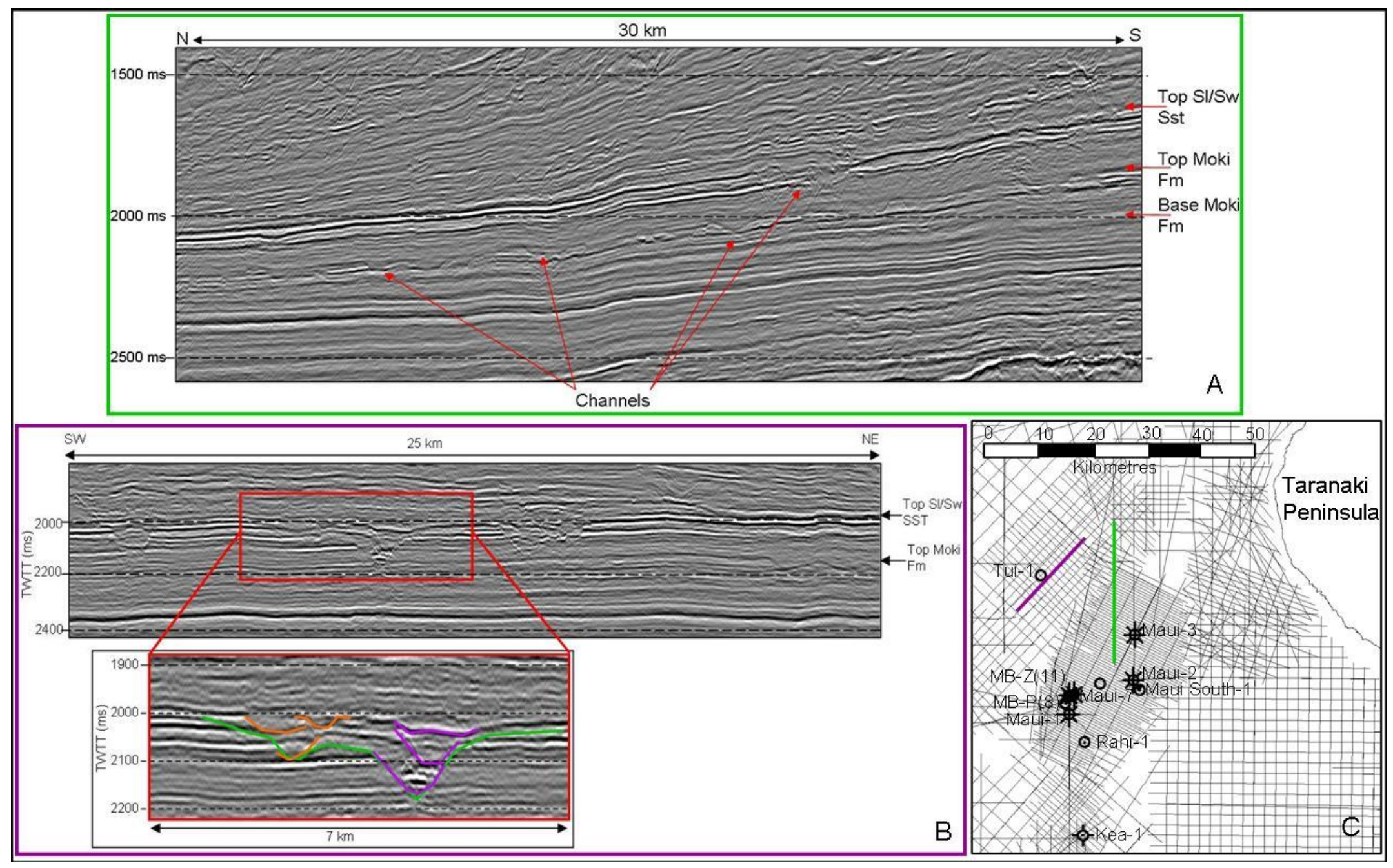

Figure 4.6: Seismic profiles showing channel incisions: (A) stos95-300 through the Maui field (green line on map C) showing channels which average $1 \mathrm{~km}$ across and $20 \mathrm{~ms}$ deep at both top Moki Formation and top S1/Sw Sandstone level and (B) Seismic line stos95-108 (purple line on map C) showing several channel complexes through the Sl/Sw Sandstone. Inset figure shows multiple phases of incision (orange and purple) within one channel complex (green). The entire channel complex (green) is $\sim 6 \mathrm{~km}$ wide and nearly $200 \mathrm{~ms}$ deep; individual incisions are up to 1 $\mathrm{km}$ wide and $75 \mathrm{~ms}$ deep. 


\section{Channel structure isopachs}

In order to image the channels in map view, the channels truncating several horizons (intra-Moki Formation, top Moki Formation and top S1/Sw Sandstone) were numbered according to their stratigraphic level, interpreted on 2D seismic profiles and structure maps were created.

Unfortunately, as the channels incising the Moki Formation are relatively small, and with interpolation artefacts caused by gridding, the channels were not well illustrated by this method. However, in the much larger channels of the Sl/Sw Sandstone, a complex channel system was revealed to the north and north-west of the Maui Field. Multiple channels within this region are observed to feed into one large channel extending north-northeast in the northmost extent of the study area. The initial map created also showed the presentday structure, showing a high over the Maui structure, complicating the image. To remove this ambiguity, isochrons were calculated between the top Sl/Sw Sandstone horizon and the channels that intersect this horizon (Figure 4.7) and an isopach map was created (Figure 4.8). Ideally, an underlying horizon would have been chosen such as the top Moki Formation, as this would remove the present day structure but retain the depositional dip. However, the Moki Formation does not extend far enough to the northwest beneath the channels. The isopach map between the channels at S1/Sw Sandstone level and top S1/Sw Sandstone horizon was created using a minimum curvature method, with a grid spacing of $1000 \mathrm{~m}$ and was smoothed once.

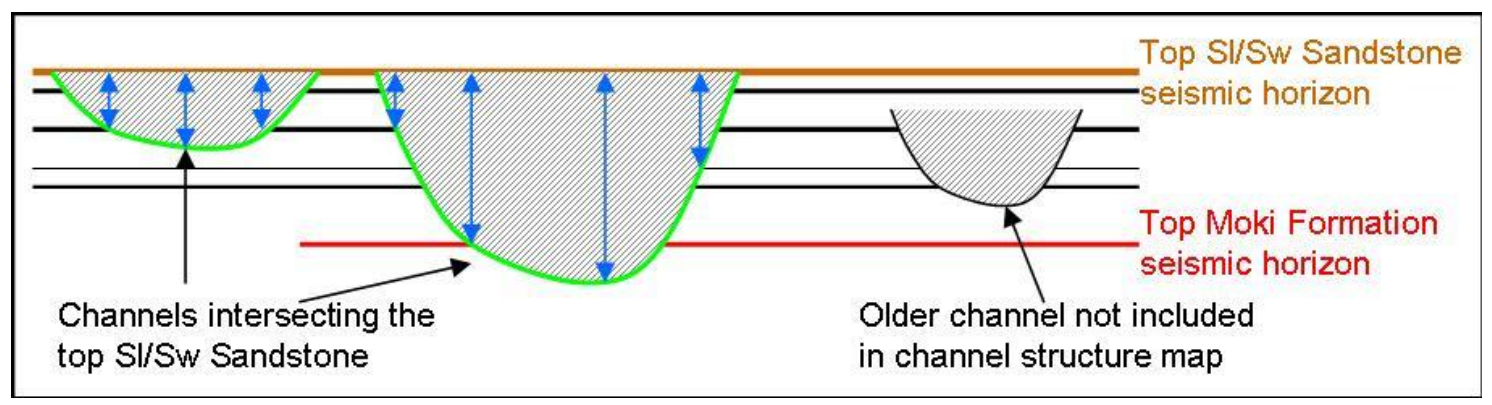

Figure 4.7: Schematic diagram illustrating the method used to to create a structure isopach map (Figure 4.8) between the channels at Sl/Sw Sandstone level (green) that were interpreted. Channels that truncated the top $\mathrm{S} 1 / \mathrm{Sw}$ Sandstone horizon were interpreted (green) and isochrons between these channels and the Sl/Sw Sandstone horizon (brown) were calculated. Note that the channels that were present within the Sl/Sw Sandstone but did not intersect the top S1/Sw Sandstone horizon (channel on right) were not interpreted and were not included in the isopach map.

The channel isopach map (Figure 4.8) shows the size and geometry of the S1/Sw Sandstone channel system. Specifically, a series of southeast to northwest trending channels merge 
with a single, large northeast to southwest trending axial channel system that extends beyond the study area.

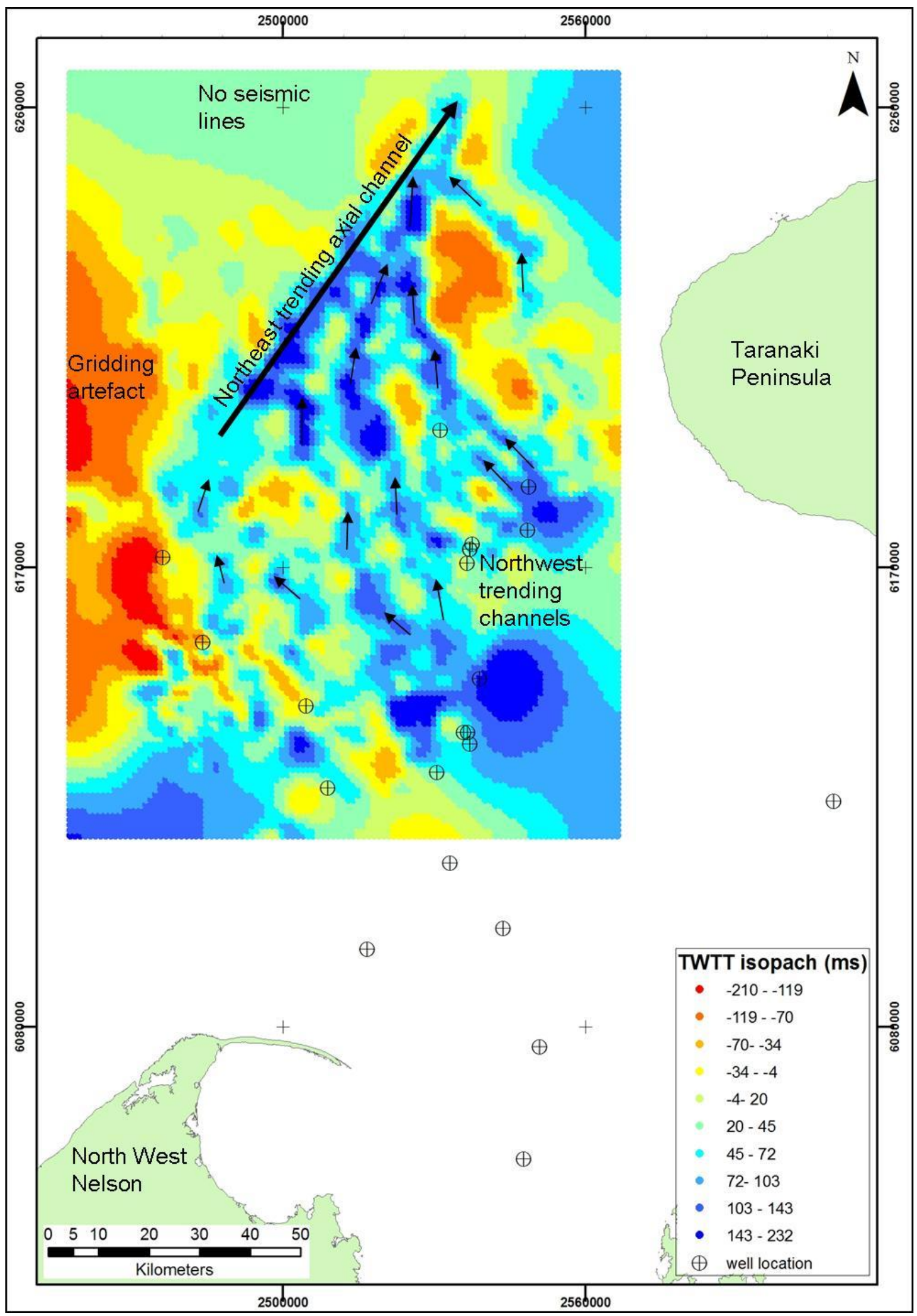

Figure 4.8: Isopach map between the top S1/Sw Sandstone horizon and the intersecting channels (see Figure 4.7). Channels are shown in dark blue and are indicated by the arrows. Many northwest trending channels merge into a large northeast trending axial channel that leads beyond the study area. 


\section{Average amplitude maps}

As the amplitude between channel infill sediments and the sediments they incise differs, average (RMS) amplitude maps should provide a good method to visualise the channel system. RMS amplitude is an average aggregated amplitude of all reflectors between two interpreted seismic intervals. RMS amplitudes were calculated for two intervals: between the top S1/Sw Sandstone and top Moki Formation, and between top and base Moki Formation. As the upper interval, between the S1/Sw Sandstone and the Moki Formation, includes the intervening Manganui Formation mudstone, which is represented by a uniform, low amplitude seismic character, the overall RMS amplitude values will be lowered but the identification of amplitude anomalies will not be affected. These average amplitudes were calculated for each 2D seismic survey and gridded independently. Although amplitude extracts are preferentially done on 3D data sets, for regional work away from 3D surveys, regularly spaced and orientated 2D surveys suffice but should be treated with caution due to the spacing and variability of 2D seismic lines. For this reason, a fine grid spacing was chosen to highlight the data points.

Unfortunately, the average amplitudes of the Moki Formation did not give satisfactory results. The RMS amplitude maps generally show low amplitude where seismic profiles show the presence of a channel through the Maui Field, but otherwise amplitudes are variable and no distinct pattern emerged. Comparisons with seismic profiles show the top Moki Formation reflector is highly variable in amplitude, probably due to changes in sandstone content, cementation as well as channelisation.

Figure 4.9 shows a composite RMS amplitude map over three 2D surveys (86ma, stos95 and sunz91) in the northwest of the study area between the top Sl/Sw Sandstone and the top Moki Formation horizons. The three RMS grids for each 2D survey were created using a minimum curvature interpolation method with a grid spacing of $50 \mathrm{~m}$ and were confined to a polygon of the area covered by each survey to reduce gridding artefacts. Channels are distinguished from the surrounding sediment by low amplitudes (blue). This composite amplitude map illustrates a similar channel distribution to the isopach map (Figure 4.8). A series of channels can be identified from the Maui Field (86ma Survey) which trend to the northwest. These channels merge with a large axial channel system leads to the north beyond the seismic coverage of this data set. 


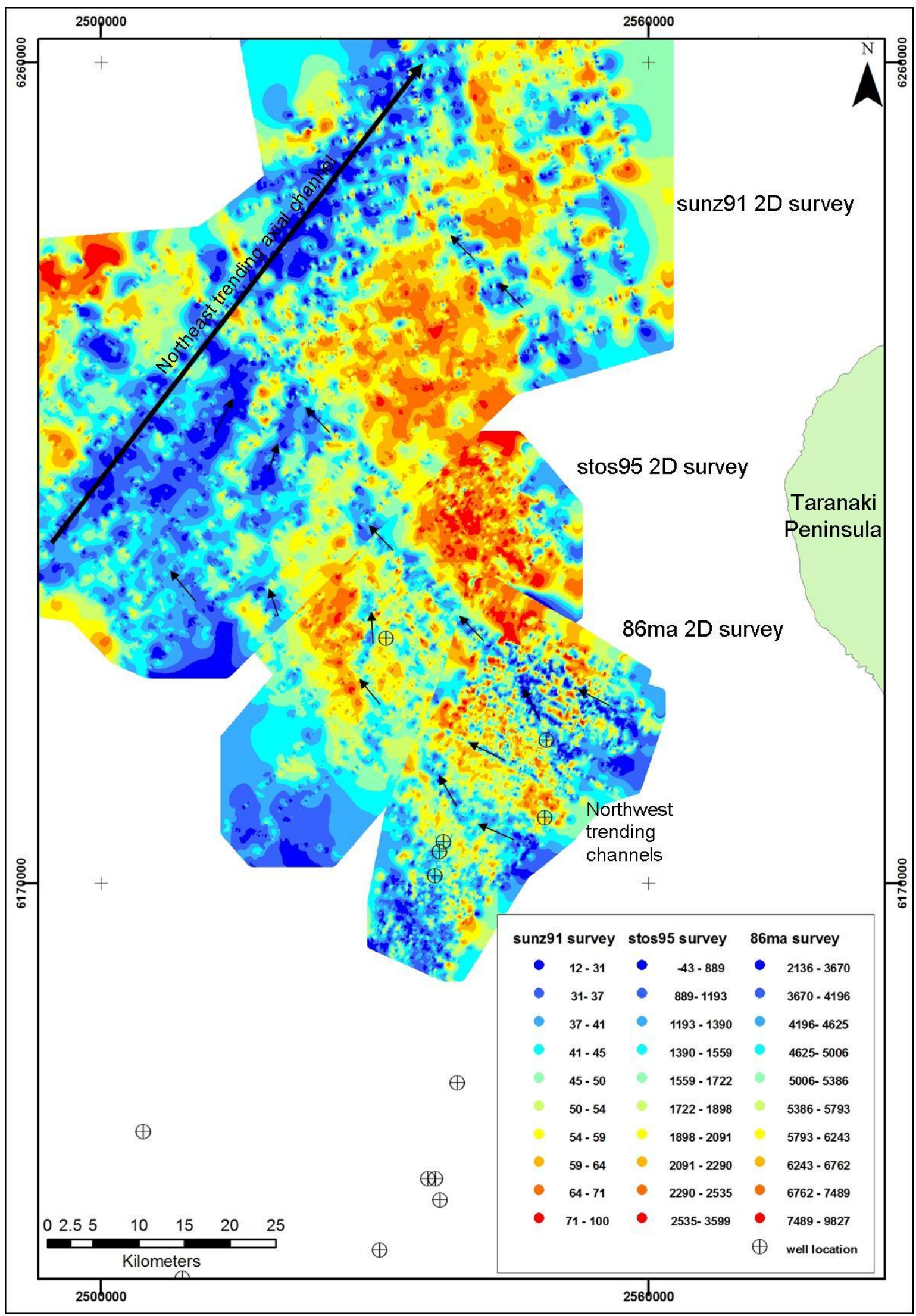

Figure 4.9: Composite RMS amplitude maps between the top S1/Sw sandstone and the top Moki Formation, created over three 2D data sets, the 86ma, stos95 and sunz91 surveys. Channels are expressed as low amplitudes (blue) and are indicated by the arrows. Many northwest trending channels can be identified over the Maui field (86 ma 2D survey), which merge into a northeast trending axial channel. Fan lobes are expressed as high amplitudes (red) in the southeast of the study area. 


\section{Semblance}

Semblance, also called coherence or variance, compares the similarity of neighbouring traces along each time horizon and is usually performed on 3D datasets. Dissimilarities are created at channel margins where infill sediments have a contrasting reflectivity to the sediment that has been incised. Dissimilarities are also caused by faults offsetting seismic horizons. The 3D seismic is coloured according to similar (brown) and non-similar traces (white). Semblance was undertaken on the Maui 3D to improve imaging of the channels in this region. Semblance was done with a trace window of $5 \mathrm{~ms}$, line window of $5 \mathrm{~ms}$ and sample time window of $5 \mathrm{~ms}$. This was not performed on the Maari-3D due to increased structure and problems with gas effects so that it was predicted semblance would not produce good results.

Initial time-slices through the S1/Sw Sandstone and Moki Formation showed channels and faults imaged in much more detail than the isopach and average amplitude maps.

However, as these were horizontal time-slices through inclined strata the channels were most likely not of the same age. Therefore, depositional stratal slices were created by flattening between two horizons, the top Sl/Sw and near base Moki Formation. On the Maui 3D seismic dataset, twenty semblance stratal slices were created which show spectacular images of meandering channels that migrate and change orientation through time. As seen on seismic profiles, there appear to be no channels near the base of the Moki Formation in the Maui Field. One major channel meander belt near the top of the Moki Formation exists, trending south-north, though there is a high degree of sinuosity with meanders looping back on themselves in a similar manner to terrestrial meandering rivers (Figure 4.10). A secondary channel is present in the southwestern quadrant of the Maui 3D survey. This channel is orientated southeast-northwest and appears to cross the Whitiki Fault without offset, implying the fault was not active during this time. With successive, upwards slices this channel becomes more sinuous with meanders taking a longer path over a wider area.

The south-north channel orientation of the Moki Formation in the Maui Field gives way to a northwest-southeast orientation of channels within the S1/Sw Sandstone (Figure 4.11). In this sandstone package, there are more channels present at any one time, and channels appear to be frequently abandoned and replaced by channels to either the northeast or southwest. Often, two or more channels will merge into a single meandering channel. The width of the channel meander belt is less than the main channel of the Moki Formation, with tighter meanders. Some channels, usually smaller ones, are almost straight. The 
channels all appear to come off the Cape Egmont Fault supporting interpretations that it was active as a reverse fault at this time, downthrown to the northwest.

The orientation and detail of the meandering channels within the Maui-3D seismic survey concur with the work by Shell Todd Oil Services (e.g. Bussell, 1994; Engbers, 2002) on the Moki Formation (their Moki B Sandstone) and S1/Sw Sandstone (their Moki A Sandstone). 


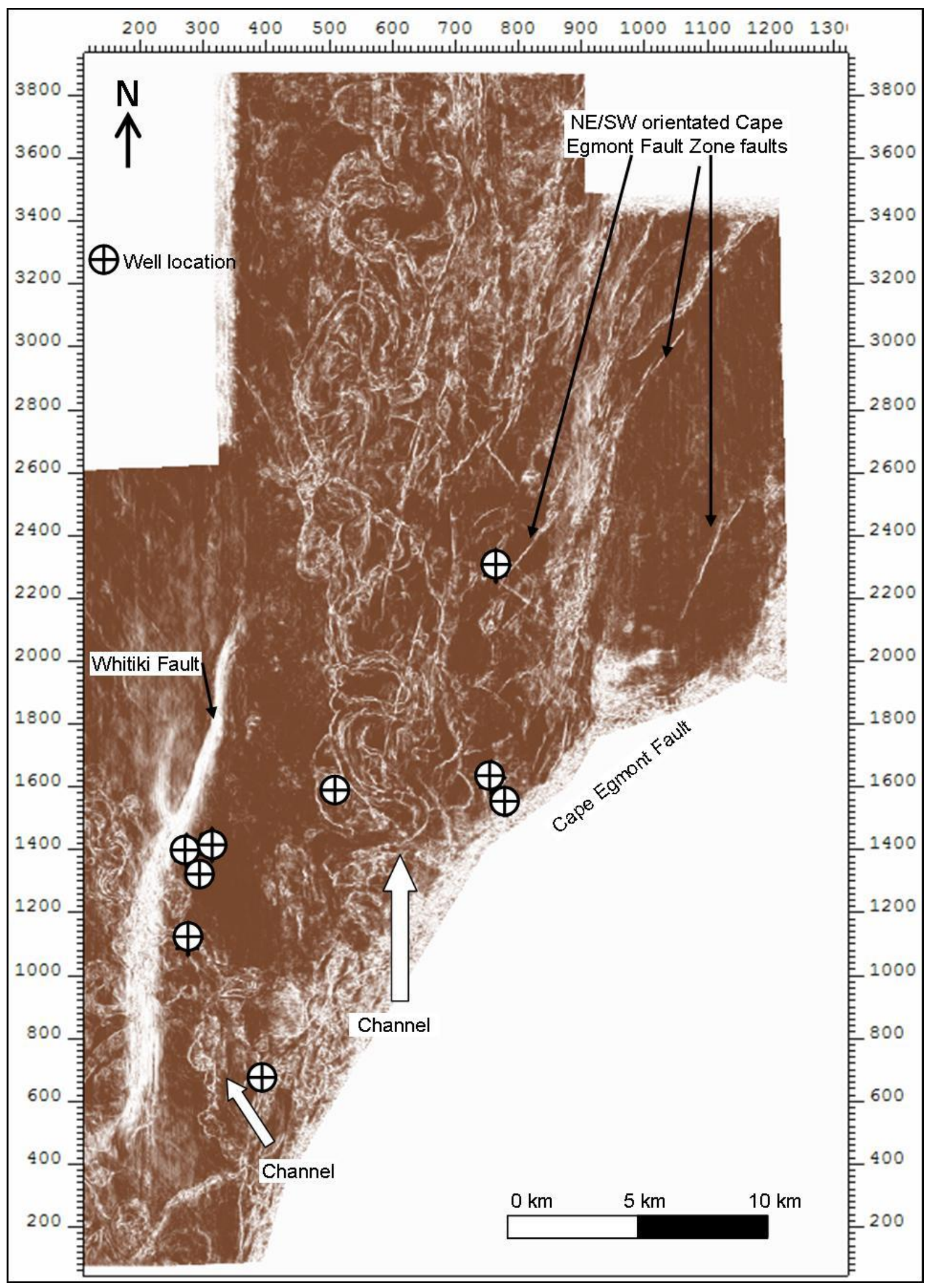

Figure 4.10: Semblance stratal slice of the Maui-3D, near top Moki Formation showing dissimilar traces in white. A large channel trends south-north with large meander loops visible; a second channel exists in the southwest of the survey trending northwest-southeast. Faults of the Cape Egmont Fault Zone trend northeastsouthwest. Inlines and crosslines are numbered on the axes. 




Figure 4.11: Semblance stratal slice of the Maui-3D, within the Sl/Sw Sandstone showing dissimilarities in white. Many meandering channels are illustrated trending to the northwest from the Cape Egmont Fault. Inlines and crosslines are numbered on the axes. 


\section{Fan channel discussion}

Channels of the Moki Formation are seen throughout the study area as seismic scale incisions but because of their relative size and character are difficult to image in plan view. In the Maui Field, there are no channels seen on seismic profiles at the base of the Moki Formation. Near the top of the formation, a major sinuous, meandering channel trends south-north and a smaller meandering channel is imaged in the southeast of the field, trending northwest-southeast which appears unaffected by the Whitiki Fault. This may be explained two ways. First, the Maui Field may have been located beyond the extent of fan channels until close to the end of the Moki Formation deposition when the fan had prograded sufficiently so that parts of the mid-fan was located over the Maui Field. Alternatively, deposition through the most part of the formation's history may have been produced widespread sheets of sediment and only began to incise channels and transporting sediment through these toward the end of the Moki Formation deposition. Seismic profiles indicate that south of the Maui Field, channels are present throughout the formation supporting the former interpretation. However, seismic quality is not as good to the south of the Maui Field and either option cannot be ruled out.

A large channel complex within the S1/Sw Sandstone has been identified and mapped showing multiple channels from the Maui Field, dominantly trending northwest/southeast leading into a large channel system, which trends north-northeast/south-southwest. This channel system would have followed the greatest depression in the sea floor, and probably led into the abyssal New Caledonia Basin where numerous large Neogene channel systems are seen on seismic profiles (Uruski, 2006).

\subsubsection{Thinning, merging, fading reflectors}

Regional mapping of the Moki Formation and its equivalents showed that the sediment package thins to the west and the north of the study area. In some areas, reflectors appear to downlap onto deeper reflectors, but the most dominant method of thinning of the Moki package appears to be caused by thinning of individual reflectors and merging with both underlying and overlying reflectors with no clear downlap surface (Figure 4.12). Thinning takes place over a large distance; in $63 \mathrm{~km}$ of seismic line in Figure 4.12 the Moki Formation Equivalent package thins from $220 \mathrm{~ms}$ to $50 \mathrm{~ms}$ thick. Downlapping reflectors appear to be more dominant in southern parts of the Western Stable Platform suggesting progradation was more apparent in proximal areas. 


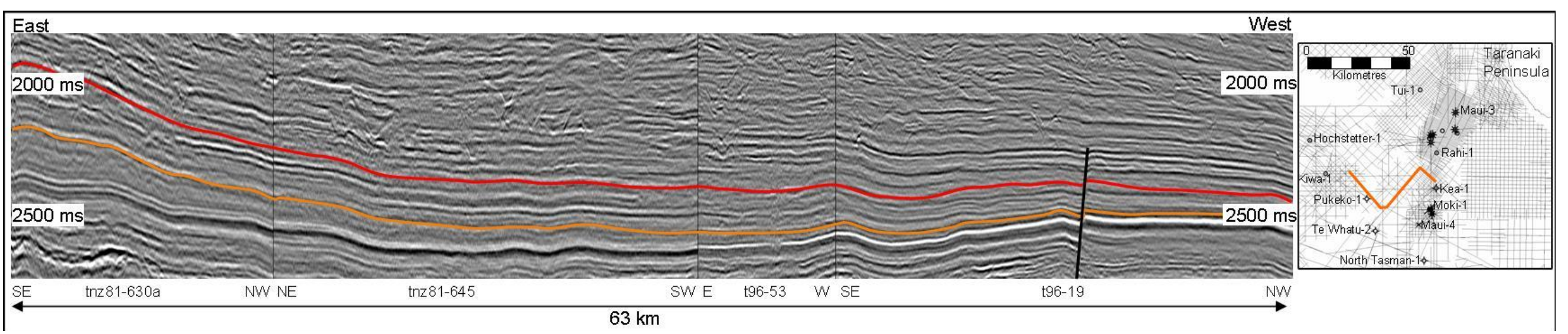

Figure 4.12: East-West composite line with top Moki Formation Equivalent (red) and near base Moki Formation Equivalent (orange) interpreted. Line shows a thinning to the west, by merging and thinning of reflectors. Reflectors vary in amplitude from east to west, due to either tuning effects as beds thin, changes in lithology, cementation or fluid content. Channels occur in the east of the composite line at $\sim 2000 \mathrm{~ms}$ below the top Moki Formation Equivalent horizon. 
In this area, the internal reflection character of the Moki Formation Equivalent is subparallel with variable amplitude of individual reflectors. Increased amplitudes may be due to sand bodies, concretionary or cemented layers or seismic tuning effects as beds thin. In Te Whatu-2, Pukeko-1 and Kiwa-1 wells, the Moki Formation equivalent is comprised of thin sandstone packages which typically fine upwards, showing a much lower net:gross sandstone ratio than wells in the centre of the study area. This change from the sandstonedominated package typical of the Moki Formation is likely to be responsible for the change of seismic character. This seismic character is probably representative of the outer fan of the Moki Formation turbidite complex.

\subsection{Summary}

Seismic facies changes within the Moki Formation and the Sl/Sw Sandstone and their time equivalents have been identified, described and mapped, providing key constraints for the Mid Miocene palaeogeography. These include

- $\quad$ prograding clinoforms representing the coeval shelf-slope break of the Moki Formation with evidence for both mass wasting and channelisation;

- $\quad$ large channel incisions on the coeval shelf of the S1/Sw sandstone;

- $\quad$ high-amplitude seismic character typical of the Moki Formation with a definitive eastern limit and a variable western extent;

- $\quad$ amplitude variations within the Maari field which may be, at least in part, caused by changes in lithology, therefore implying fan switching, and

- $\quad$ channels within the Maui Field and farther northwest at both Moki Formation and Sl/Sw Sandstone levels imaged showing spectacular complex, meandering channel systems. 


\subsection{Wireline logs}

\subsection{Introduction}

Wireline logs provide the most consistent record of the subsurface that is penetrated by a well by measuring the geophysical properties from which lithology, porosity and pore fluid type can be deduced (North, 1985). Wireline tools are generally run over the entire length of the well with resolution down to a few metres. Calibrated to other data such as cuttings, sidewall cores, conventional drill cores or seismic profiles, wireline logs can be extremely useful. On a large scale, correlation of wireline logs between wells provides information of the vertical and lateral variations in formation thickness and lithology. On a smaller scale, changes in log curve shape or motif can provide insight into lateral and vertical "facies" variations.

In this project, 13 wells were selected for wireline log analysis, covering most of the study area (Figure 5.1). The wireline logs of these key wells were used to identify wireline facies and their lateral and vertical changes providing more detail about the depositional environment of the Moki Formation. Three wireline log correlations were created to illustrate the spatial and temporal changes in the formation and its sandstone content across the fan system. This chapter discusses the wireline log analysis of the Mid Miocene sediments at these 13 wells. All depths referred to are Along Hole Below Drilling Floor (AHBDF). 


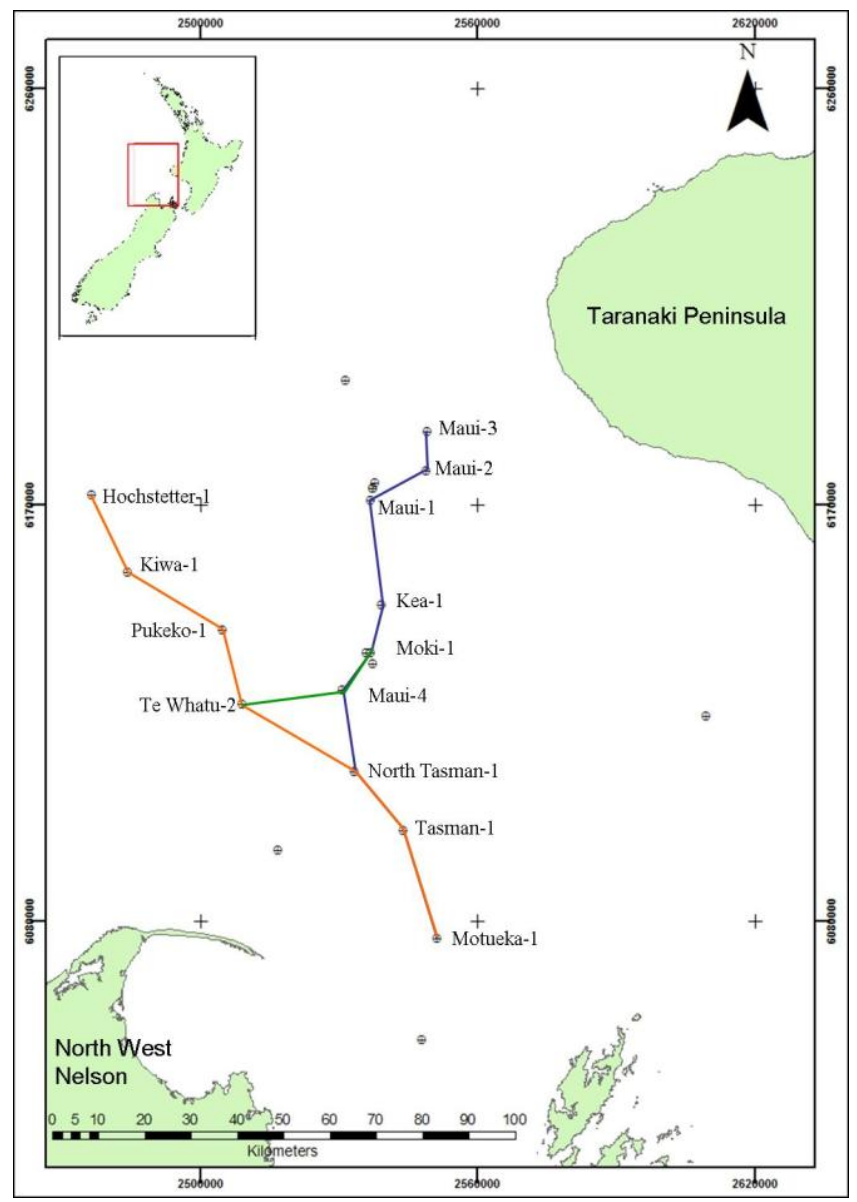

Figure 5.1: Location map of the 13 wells used for wireline log analysis and correlation. The three coloured correlation lines refer to Well Correlation 1 (blue; Figure 5.7), Well Correlation 2 (orange; Figure 5.8) and Well Correlation 3 (green; Figure 5.9).

\subsection{Overview of wireline logs}

Standard wireline runs include gamma ray, Spontaneous Potential (SP), various resistivity tools, sonic, neutron and density logs (summarised in Table 5.1). Wireline logging of the well is done after each section of the well is drilled, before it is cased. To reduce costs, sometimes only the final hole section is logged, but gamma ray is usually done over the entire well through the casing.

The Spontaneous Potential (SP) tool measures the natural spontaneous potential of a rock measured in millivolts $(\mathrm{mV})$ between an electrode in contact with the rock while being pulled up the hole, and a reference electrode at the surface (e.g. Cant, 1984). This potential is caused by differences in salinities between the drilling fluid and the formation water (e.g. North, 1985). In muddy sections, the SP response will be relatively constant, defining a "shale line" (Cant, 1984); deflections off this line indicate zones of permeable rock containing pore fluid with differing salinities to the drilling fluid. 


\begin{tabular}{|c|c|c|c|c|c|}
\hline Log & $\begin{array}{l}\text { Property } \\
\text { measured }\end{array}$ & Units & Geological uses & $\begin{array}{l}\text { More positive } \\
\text { measurement }\end{array}$ & $\begin{array}{l}\text { More negative } \\
\text { measurement }\end{array}$ \\
\hline Calliper & $\begin{array}{l}\text { Borehole } \\
\text { diameter }\end{array}$ & Inches & $\begin{array}{l}\text { Evaluate hole } \\
\text { condition and the } \\
\text { reliability of other } \\
\text { logs }\end{array}$ & $\begin{array}{l}\text { Wider hole } \\
\text { (borehole } \\
\text { break out) }\end{array}$ & Tighter hole \\
\hline $\begin{array}{l}\text { Spontaneous } \\
\text { potential }\end{array}$ & $\begin{array}{l}\text { Natural electric } \\
\text { potential } \\
\text { compared to } \\
\text { the drilling fluid }\end{array}$ & Millivolts (mV) & $\begin{array}{l}\text { Lithology, } \\
\text { correlation, curve } \\
\text { shape analysis, } \\
\text { identification of } \\
\text { porous zones }\end{array}$ & $\begin{array}{l}\text { Non-Porous } \\
\text { bed }\end{array}$ & Porous bed \\
\hline Resistivity & $\begin{array}{l}\text { Resistance to } \\
\text { electric current } \\
\text { flow }\end{array}$ & $\begin{array}{l}\text { ohm metres } \\
\text { (ohm m) }\end{array}$ & $\begin{array}{l}\text { Identification of coals } \\
\text { and fluid evaluation }\end{array}$ & $\begin{array}{l}\text { Non- } \\
\text { permeable } \\
\text { sediment / } \\
\text { hydrocarbons }\end{array}$ & $\begin{array}{l}\text { Permeable bed } \\
\text { / brine pore } \\
\text { fluid }\end{array}$ \\
\hline Sonic & $\begin{array}{l}\text { Velocity of the } \\
\text { compressional } \\
\text { sound wave }\end{array}$ & $\begin{array}{l}\text { microseconds / } \\
\text { metre }(\mathrm{ms} / \mathrm{m})\end{array}$ & $\begin{array}{l}\text { Identification of } \\
\text { porous zones, coals } \\
\text { and tightly cemented } \\
\text { zones }\end{array}$ & $\begin{array}{l}\text { Dense, } \\
\text { cemented or } \\
\text { non-porous } \\
\text { sediment }\end{array}$ & $\begin{array}{l}\text { Porous and / or } \\
\text { gas-filled } \\
\text { sediment }\end{array}$ \\
\hline Neutron & $\begin{array}{l}\text { Concentration } \\
\text { of hydrogen in } \\
\text { pores }\end{array}$ & $\begin{array}{l}\text { Percent } \\
\text { porosity }\end{array}$ & $\begin{array}{l}\text { Identification of } \\
\text { porous zones }\end{array}$ & $\begin{array}{l}\text { non-porous or } \\
\text { coaly sediment }\end{array}$ & $\begin{array}{l}\text { Porous and / or } \\
\text { gas-filled } \\
\text { sediment }\end{array}$ \\
\hline Density & $\begin{array}{l}\text { Bulk density } \\
\text { (electron } \\
\text { density) }\end{array}$ & $\begin{array}{l}\text { Kilograms per } \\
\text { cubic meter } \\
\left(\mathrm{gm} / \mathrm{cm}^{3}\right)\end{array}$ & $\begin{array}{l}\text { Identification of some } \\
\text { lithologies, and } \\
\text { porosity where } \\
\text { lithology is known }\end{array}$ & $\begin{array}{l}\text { Non-porous } \\
\text { rocks }\end{array}$ & $\begin{array}{l}\text { Porous and /or } \\
\text { gas-filled } \\
\text { sediment }\end{array}$ \\
\hline Gamma ray & $\begin{array}{l}\text { Natural } \\
\text { radioactivity } \\
(\mathrm{K}, \mathrm{Th}, \mathrm{U})\end{array}$ & API units & $\begin{array}{l}\text { Lithology (particularly } \\
\text { sand vs. mud), } \\
\text { correlation, curve } \\
\text { shape analysis }\end{array}$ & More muddy & Less muddy \\
\hline
\end{tabular}

Table 5.1: Summary of wireline logs. Modified after Cant (1984).

Resistivity tools measure the natural resistivity of the rock and its pore fluids. Current is supplied at the base of the tool and measured by electrodes at various distances along the tool (North, 1985). Because rock is non-conductive, resistivity is determined almost entirely by the pore fluid and the permeability of the rock. The main use of resistivity logs is to determine zones of hydrocarbons, but it can also be used to indicate permeable zones (Cant, 1984). Hydrocarbons will produce more positive (higher) resistivity values compared to the salty formation water; permeable beds are indicated by values that are more negative (lower). 
The sonic tool records the time taken for the travel of a compressional sound wave through the drilling fluid, formation and back to two receivers below the transmitter. The velocity of sound is dependant on the lithology of the rock, interconnected pore space and the type of fluid in the pores (Cant, 1984). Beds such as coals and very porous rocks will have low velocities whereas tightly cemented carbonates, for example, will have very high velocities.

The neutron tool measures the hydrogen ion concentration in a formation by emitting neutrons from a neutron source on the wireline tool and measuring the energy of the returning neutrons. The energy loss is a function of a formation's hydrogen ion concentration and as these are concentrated in pores, the energy loss can be correlated to the formation's porosity (North, 1985).

The density tool measures the electron density of the formation. Gamma rays emitted into the formation, are scattered by collision with electrons in the formation, and the number of returning gamma rays are counted; the number is a direct function of the bulk density of the rock and its pore fluids, and thus the formation porosity may be calculated (North, 1985).

The gamma ray tool is the most useful wireline log for facies analysis (Cant, 1984). It measures the natural radioactivity (potassium, uranium, thorium) of the rock, concentrated in clay minerals. Thus, the gamma ray $\log$ is used to differentiate between argillaceous and non-argillaceous rocks. For example, a clean sandstone, that is a well-sorted sandstone with unreactive formation waters, has a very low natural radioactivity. Whilst the gamma ray count is not a function of grain size, the $\log$ is an important tool for wireline facies analysis as the gamma ray count mimics trends in the clay content throughout the well.

Several factors must be considered when dealing with wireline logs: (1) the well from which the logs are derived is only a "pinprick" in the basin and may not be representative of the formation as a whole; (2) the logs are an indirect method to gain formation information, affected by other factors such as the composition of the drilling fluid and borehole temperature, and (3) finely interbedded lithologies may be below the resolution of the wireline tool so that the measurements are affected by both lithologies, providing an intermediate result (Cant, 1984). 


\subsection{Wells}

\subsubsection{Methods}

Thirteen wells were selected for wireline log analysis and correlation based on adequate wireline log coverage over the Mid Miocene interval, palaeontological data and proximity to other selected wells. These selected wells were Hochstetter-1, Kiwa-1, Pukeko-1, Te Whatu-2, Maui-4, Motueka-1, Tasman-1, North Tasman-1, Moki-1, Kea-1, Maui-1, Maui2 and Maui-3 (Figure 5.1). Unfortunately, Tui-1, to the northwest of the Maui Field was not included in this review due to complications with the wireline logs. As wells are typically drilled on structural highs there are no wells drilled in the eastern part of the study area, west of the Manaia Anticline.

Well sheets were made for the Altonian to Waiauan section of these 13 key wells (Appendix E). Well logs and other well data came from open file petroleum reports held by the Ministry of Economic Development. Pre-existing GNS well sheets were modified for this review and three new well sheets were created for Tasman-1, Maui-1 and Pukeko1. A new well sheet template was created to incorporate the information important for this detailed Mid Miocene review. Due to time constraints, no corrections were applied to the logs. Open-file biostratigraphy reports provided palaeontological sample data including depth, age and palaeoenvironment and key biomarkers, which were added to the well sheets.

Lithology was interpreted from wireline logs with comparison of cutting sample descriptions included in the well completion reports. Formation nomenclature and boundaries were revised (Table 5.2) based on lithology, age data and correlation of wireline logs and seismic, following the definitions outlined in Chapter 2. Wells on the Western Stable Platform proved problematic for formation subdivision, as there is no typical Moki Formation wireline or seismic character and no concentration of sandstones in sediment of this age. Therefore, formation boundaries are somewhat subjective (see also de Bock et al., 1991). 


\begin{tabular}{|c|c|c|c|c|c|c|c|c|c|c|c|c|c|}
\hline & 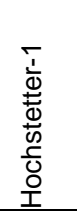 & $\begin{array}{r}\overline{1} \\
\mathbb{\Phi} \\
\end{array}$ & $\underset{1}{\frac{1}{3}}$ & 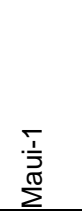 & $\frac{N}{3}$ & $\begin{array}{l}m \\
\frac{1}{J} \\
\sum \\
\Sigma\end{array}$ & 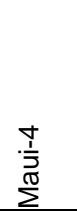 & $\frac{\overline{1}}{\frac{1}{y}}$ & 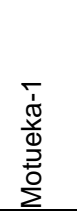 & 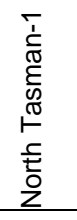 & 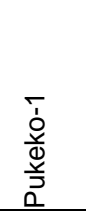 & $\begin{array}{l}\bar{c} \\
\frac{\llcorner}{\sigma} \\
\frac{E}{\mathscr{D}} \\
\stackrel{\varpi}{\models}\end{array}$ & 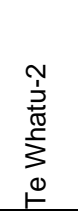 \\
\hline $\begin{array}{l}\text { Top Manganui } \\
\text { Formation }\end{array}$ & 1550 & 1047 & 1550 & 605 & 715 & 750 & 422 & 567 & - & 292 & 2550 & 300 & 425 \\
\hline $\begin{array}{l}\text { Top SI/Sw } \\
\text { Sandstone }\end{array}$ & - & - & - & 1825 & 1635 & 1832 & 716 & 980 & 385 & 645 & - & - & - \\
\hline $\begin{array}{l}\text { Base SI/Sw } \\
\text { Sandstone }\end{array}$ & - & - & - & 1994 & 1687 & 1914 & 773 & 1010 & 578 & 691 & - & - & - \\
\hline $\begin{array}{l}\text { Top Moki } \\
\text { Formation }\end{array}$ & - & 2208 & 2818 & 2128 & 2096 & 2133 & 1328 & 1304 & 815 & 1283 & 2960 & 799 & 2635 \\
\hline $\begin{array}{l}\text { Base Moki } \\
\text { Formation }\end{array}$ & - & 2574 & 2888 & 2333 & 2413 & 2367 & 1707 & 1834 & 855 & 1567 & 3100 & 1009 & 2925 \\
\hline $\begin{array}{l}\text { Base Manganui } \\
\text { Formation }\end{array}$ & 2711 & 2805 & 2950 & 2535 & 2556 & 2523 & 1890 & 2038 & 1400 & 1821 & 3200 & 1210 & 3123 \\
\hline
\end{tabular}

Table 5.2: Revised formation tops. The Moki Formation tops in Kiwa-1, Pukeko-1, Te Whatu-2 refer to Moki Formation equivalent and are defined by well log and seismic correlation. Formation tops in Motueka1 refer to the time equivalents.

\subsubsection{Results and discussion}

\section{Palaeobathymetry}

Foraminifera from most wells record mid- to lower-slope water depths during the Mid Miocene. These depths tend to deepen toward the northwest. Uppermost slope and shelf fauna were identified from samples from Motueka-1 and a shelf-slope break was observed on seismic profiles (Chapter 4) in the southeast of the study area. Thus, a bathymetric profile for the Mid Miocene is interpreted as shelf and uppermost slope in the southeast, with mid- to lower-slope through the centre and increasing depth toward the northwest of the study area.

A bathymetric deepening in the Clifdenian was recorded by foraminifera in several wells including Kea-1 (mid -to lower-slope), Maui-3 (outer-shelf to uppermost-slope), Moki-1 (mid- to lower-slope), North Tasman-1 (upper-slope to mid-slope or deeper) and Te Whatu-2 (mid- to lower-slope). This deepening appears to have occurred concurrently with the initiation of large volumes of sand to the basin; the two events may be related.

After this bathymetric deepening, a shallowing in water depth is recorded in many of the wells during the Lillburnian to Waiauan, including Motueka-1 (outer-shelf to mid-shelf), 
Tasman-1 (lower- to mid-lower slope), North Tasman-1 (mid-lower slope to shelf-slope break) and Kea-1 (lower to uppermost slope). This shallowing may be primarily caused by the high sediment supply to the basin during this time.

The Moki Formation is interpreted to be a basin-floor turbidite complex with its sandstones deposited consistently at mid- to lower-slope depths. Some authors have suggested that the $\mathrm{Sl} / \mathrm{Sw}$ Sandstone is a base-of-slope turbidite complex (e.g. Engbers, 2002), which is indicated by observations of the overall sea-level regression, the heavy channelisation observed (see Chapter 4), the lower net:gross sandstone ratio and the sandstones appear to cover a smaller geographic area. However, there is little supporting evidence in the palaeontological data of a strong shallowing through the Maui and Tui fields where these sandstones are best developed.

\section{Lithology and wireline log character}

Typically, the wireline log character of the Moki Formation consists of repeated, thick, blocky sandstone packages between the massive mudstones of the Manganui Formation. The blocky motif is defined as a thick package of sandstone with sharp basal and upper contacts (Figure 5.2A) and corresponds to the well-sorted, thick-bedded or amalgamated sandstone packages observed in cores (Chapter 6). De Bock et al. (1991) relate this blocky motif to mid fan channel sandstones; whilst this may be correct in some cases there is no indication on seismic profiles that supports this interpretation as a stead-fast rule. Rather, this wireline motif is most common through the centre of the area and corresponds to the continuous, moderate to high amplitude reflectors interpreted as sheet sandstones deposited by high-density currents.

Fining-upwards sandstone packages (Figure 5.2B; bell shape motif of Cant, 1984) also commonly occur, particularly in wells on the Western Stable Platform. This motif has been interpreted by de Bock (1994) as overbank and channel deposits. Here, they are interpreted primarily as outer fan deposits of waning-flow density currents, as they are common where seismic profiles shows thinning of individual reflectors and reflector packages. The associated seismic character is also typical of outer fan deposits. Finingupwards motifs may also represent sediment deposited in channels during channel abandonment.

Within the blocky and fining-up sandstone packages, gamma ray and SP logs often show a spiky appearance, indicating the presence of thin mudstone beds or amalgamation surfaces 
within these packages (also see discussion in de Bock, 1994; King and Thrasher, 1996). Thus, the motifs represent amalgamated sediment packages, deposited by more than density flow.

In addition, some logs show irregular motifs of heterolithic alternations between clean sandstones and mudstones (Figure 5.2C). This motif is interpreted primarily as fan fringe deposition as it is particularly common in wells, such as Pukeko-1, where a thinning of seismic reflectors and reflector packages suggests fan terminations (see also Chapter 4).

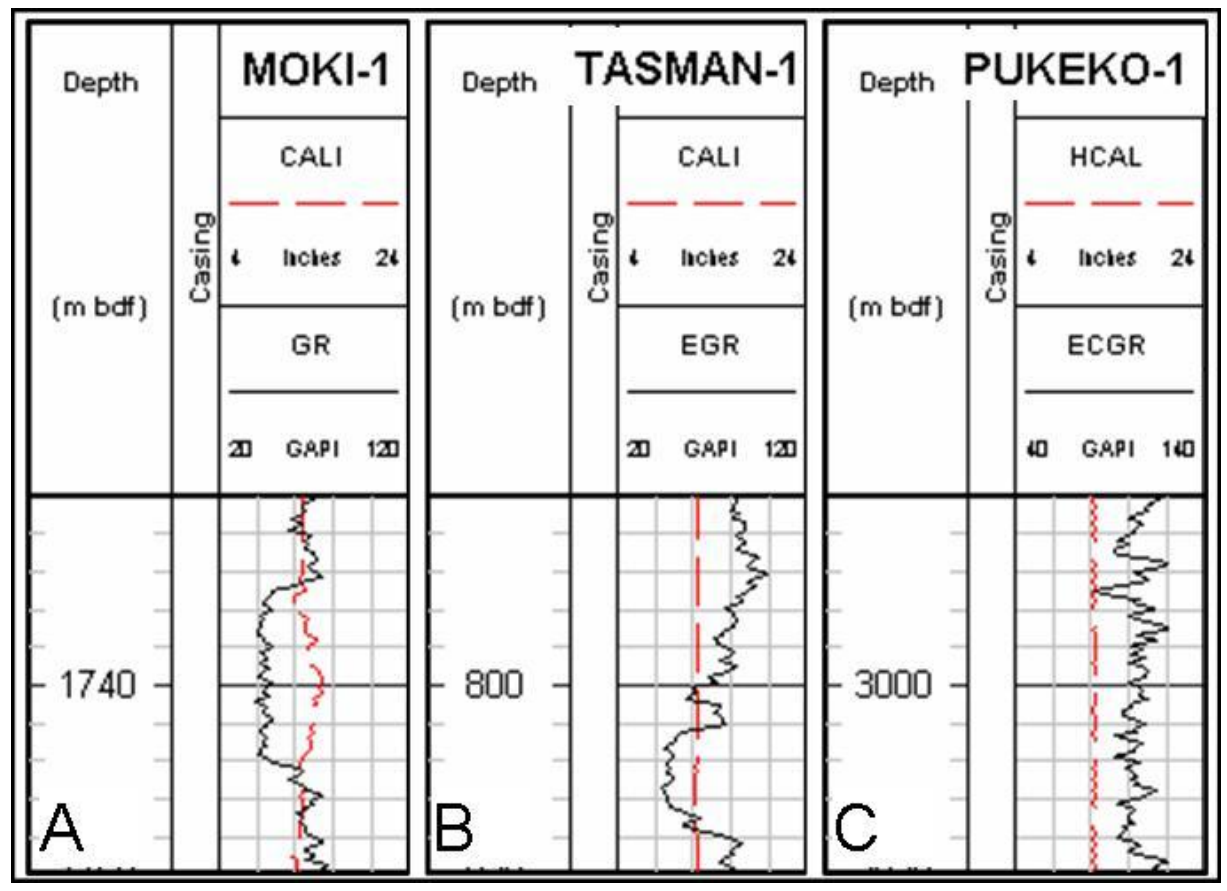

Figure 5.2: Typical gamma ray log motifs. (A) blocky motif with sharp basal and upper contacts, also note the spiky character within the blocky sandstone suggestive of thin mudstone interbeds or amalgamation surfaces from 1720 - $1760 \mathrm{~m}$ bdf in Moki-1. (B) fining-upwards sandstone log motif, again note the spiky character within this package, which increases upwards from 780 - $820 \mathrm{~m}$ bdf in Tasman-1. (C) irregular / spiky motif indicative of finely interbedded heterolithic facies from 2880 - $3020 \mathrm{~m}$ bdf in Pukeko-1. Grey, horizontal lines represent well depth increments of $4 \mathrm{~m}$.

Motueka-1 is the southernmost well used in this study. Foraminiferal assemblages indicate that during the Mid Miocene this location shallowed from mid-slope in the Late Altonian to upper slope in the Clifdenian and to shelf depths in the Early Lillburnian (Scott, 1991). Wireline logs and cutting samples show that the Mid Miocene sediment is almost entirely mudstone except for a few Lillburnian-aged fining-upwards sandstones between 815 and $855 \mathrm{~m}$ and some Upper Lillburnian-aged blocky sandstones between 385 and $578 \mathrm{~m}$

(Figure 5.3). These sandstones are the only record of shelf sandstones of this age in the Taranaki Basin and, therefore, are not directly correlatable with sandstones of the Moki 
Formation or other younger bathyal sandstones. Accordingly, the upper blocky sandstones have been renamed the Otunui Formation Equivalent (this study; see discussion in Chapter 2) after the Otunui Formation of the King Country Basin (see Kamp et al., 2004) and the older, thinner sandstones are simply included within the Manganui Formation.

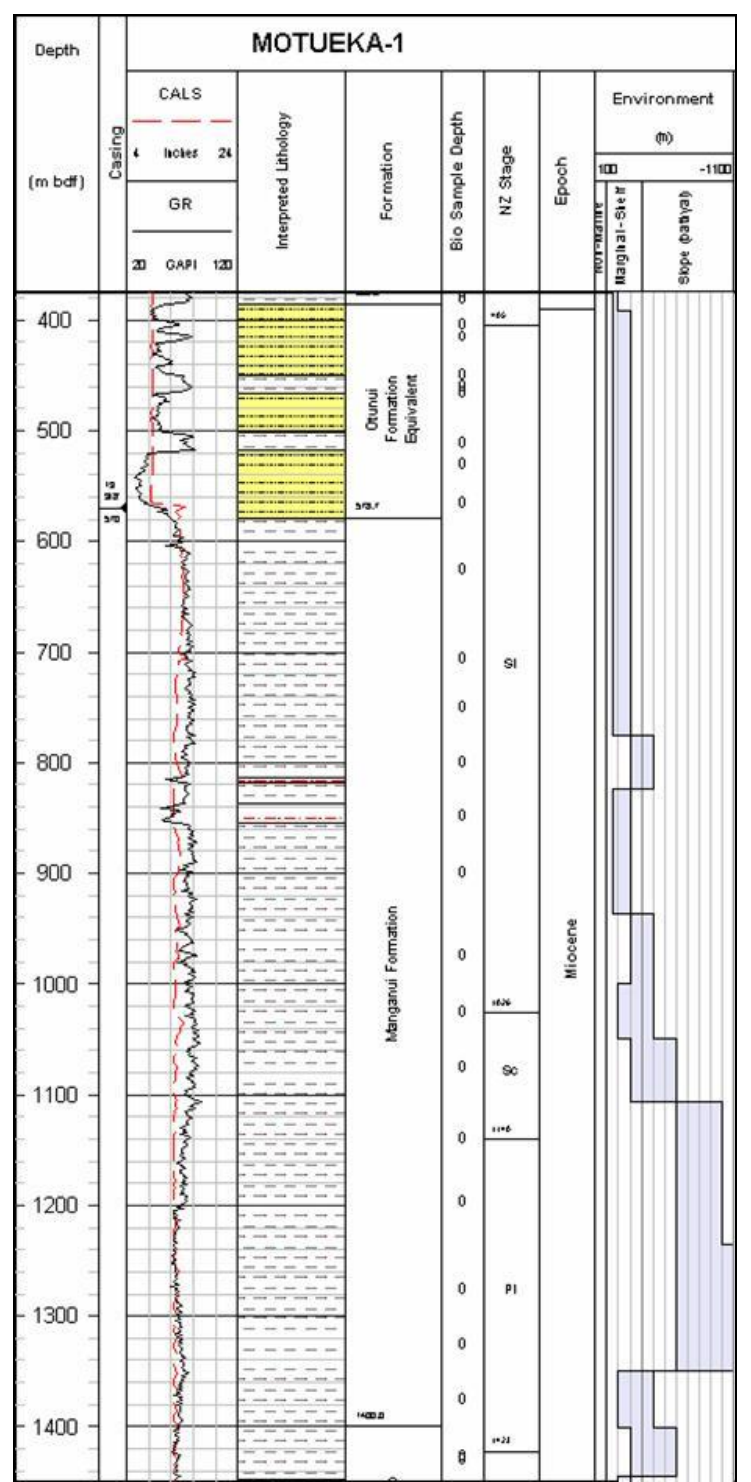

Figure 5.3: Gamma ray log from Motueka-1 well with interpreted lithology, formation names and biostratigraphy data. Sediment deposited during the Mid-Miocene is dominated by mudstone.

Foraminiferal palaeobathymetry indicates a change from slope to shelf at $1100 \mathrm{~m}$.

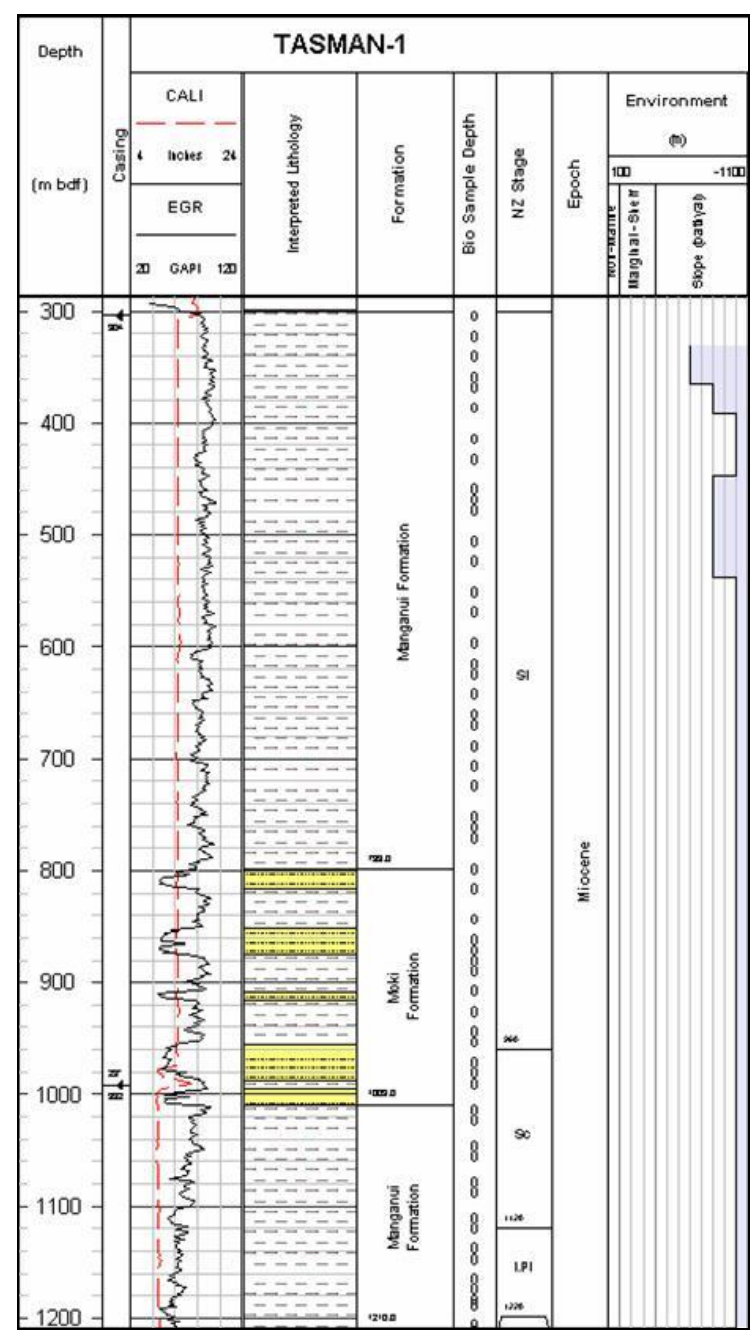

Figure 5.4: Tasman-1 gamma ray log showing blocky and fining upwards sandstone bodies of the Moki Formation interbedded with thick mudstone packages.

Tasman-1 is the southernmost well that intercepted Moki Formation sandstones. Here the formation is present as thick tabular sandstone packages (5 - $20 \mathrm{~m}$ thick) interbedded with 10-30 m thick mudstones (Figure 5.4). The presence of these thick mudstones, and the 
relatively thin formation thickness compared to farther north suggests possible periodic sediment bypass at this relatively proximal position (c.f. de Bock, 1994).

Farther north, North Tasman-1, Maui-4, Moki-1, Kea-1 and the Maui Field wells all show the classic Moki Formation wireline log motif of thick, blocky amalgamated sandstones with subordinate interbedded mudstones (Figure 5.5) suggesting these wells penetrated sediment deposited in mid-fan positions. In addition, older, Altonian-aged sandstones were only intersected in Moki-1 and Maui-4. Formation thickness and sandstone net:gross ratios increase northward to an apparent maximum at Moki-1, and thin and fine northwards thereafter. As King and Thrasher (1996) noted, the SP log from Maui-4 shows a coarsening and thickening of sandstone bodies upwards, suggestive of fan progradation at this site.

Tui-1, located on the Western Stable Platform to the northwest of the Maui Field, penetrated less than $100 \mathrm{~m}$ of muddy sandstone of Lillburnian-age. Throughout the $100 \mathrm{~m}$, three sandstones ranging from 11 to $26 \mathrm{~m}$ in thickness are identifiable on wireline logs (New Zealand Overseas Petroleum Ltd, 2003) indicating that the Moki Formation fans extended this far, but the site was in a more distal location than the Maui Field.

To the west of Maui-4, Te Whatu-2 encountered a series of fining-upwards sandstones of Clifdenian to early Lillburnian age with a much lower net:gross sandstone ratio than Maui4 (Figure 5.6). This wireline log character implies that the well location was in a position where density flows were diluted after having deposited most of their load on the central fan. Whilst the Mid Miocene sediment in Te Whatu-2 is typically finer than Maui-4 and Moki-1, it is of comparable thickness. De Bock (1994) suggested that the lack of coarse sediment and overall fining-upwards sandstone packages in Te Whatu-2 was due to possible syn-sedimentary uplift of the Te Whatu-2 structure, causing sediment of the Moki Formation to be deposited as onlapping deposits. However, no reflectors are observed to onlap this structure on seismic profiles. Sandstones are identified throughout the Miocene interval of Te Whatu-2 with no obvious concentration of coarser sediment at the time of Moki Formation deposition. These Mid Lillburnian- to Waiauan-aged sandstones are not present in the central wells, which may suggest a slight westward and down-slope shift in sediment depocentres after deposition of the Moki Formation. 


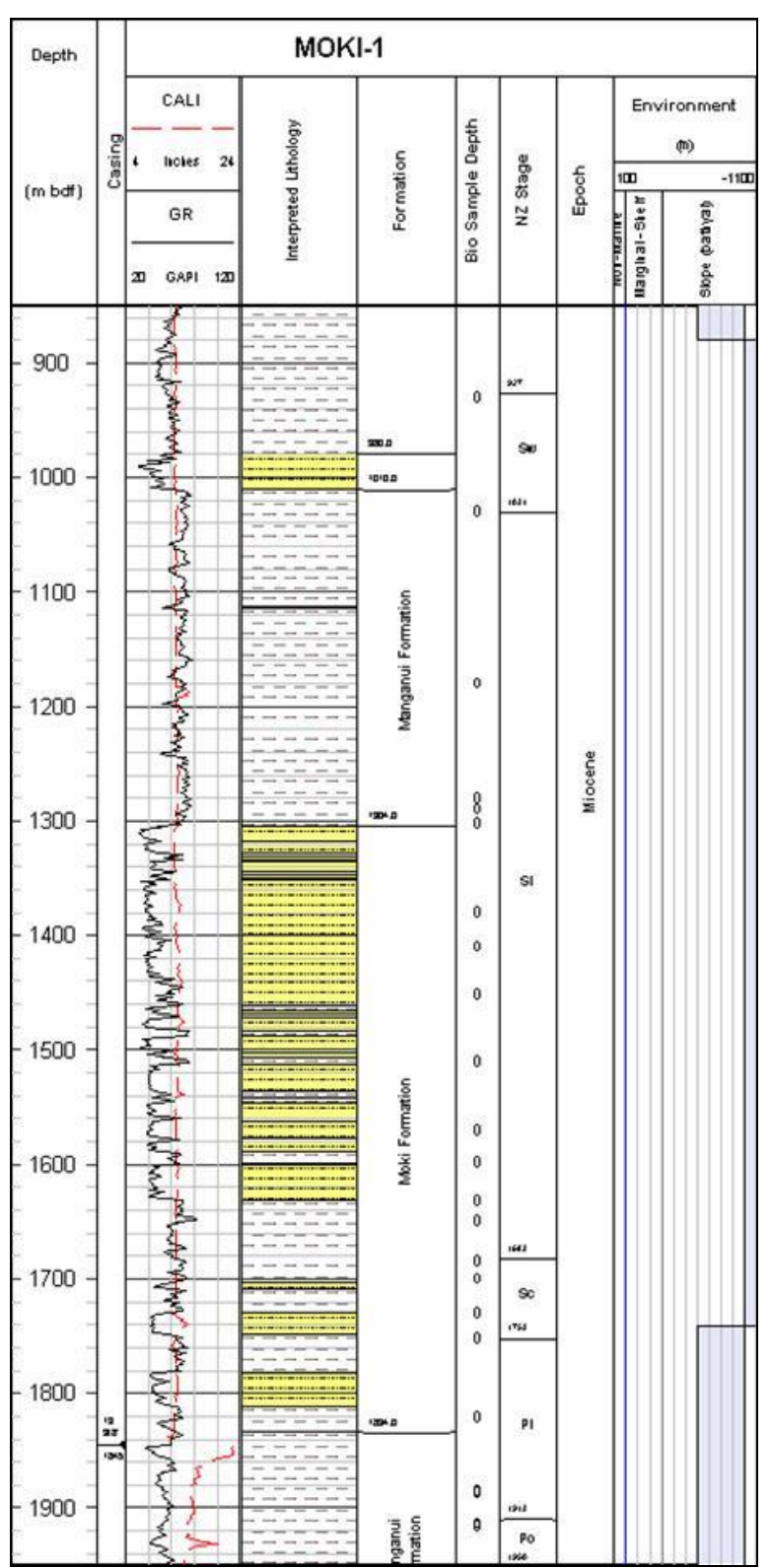

Figure 5.5: Moki-1 well log showing the tabular sandstones and high net:gross sandstone ratios typical of the Moki Formation.

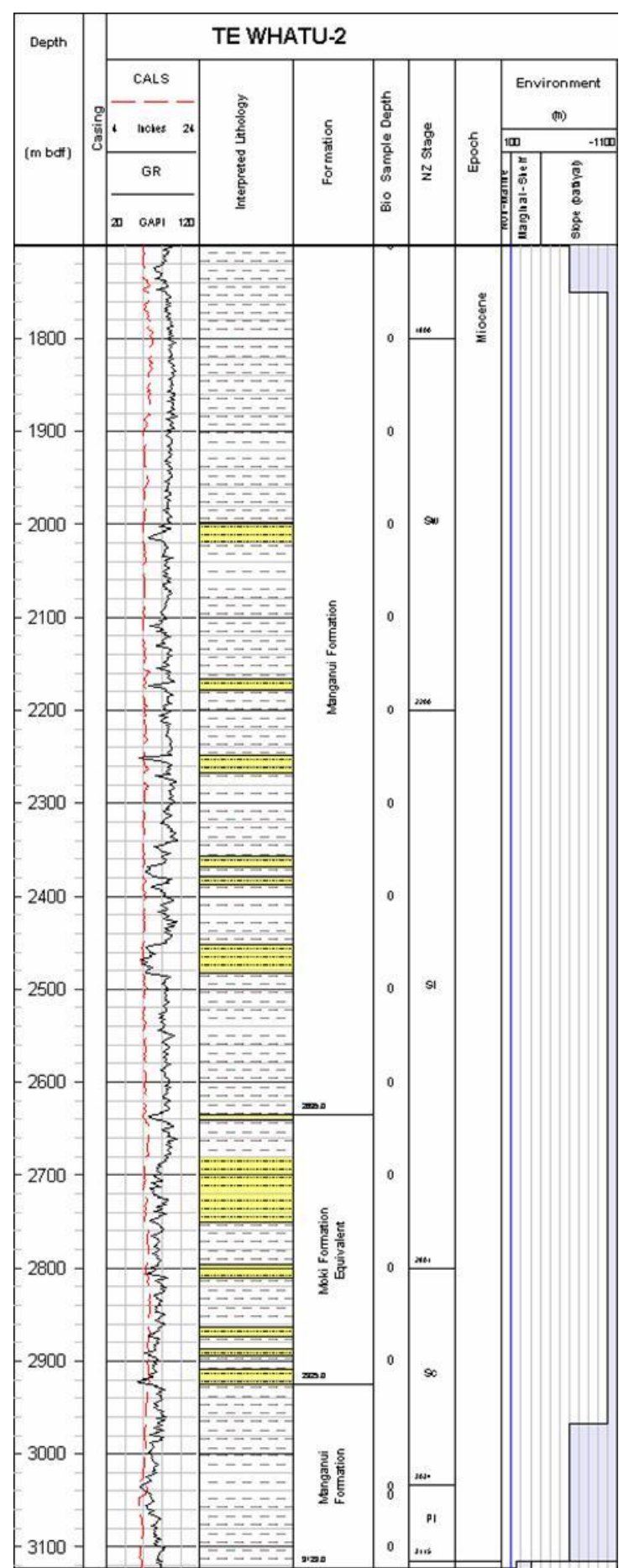

Figure 5.6: Te Whatu-2 gamma ray log showing

higher gamma ray counts than the typical Moki

Formation, with sandstones dominated by fining-

upwards packages. Also note the persistent

sandstones above the Moki Formation Equivalent.

Farther to the northwest, wireline logs of Pukeko-1 and Kiwa-1 show progressively thinner Late Altonian to Early Lillburnian sediments with fewer coarse sediment packages. At

Kiwa-1 mudstone is punctuated by thin sandstones and siltstones which collectively form a fining upwards succession, which suggests the well location is near the distal limits of the fan system. Lock (1985) used the misinterpreted log analysis of the Kiwa-1 well by Shell 
BP and Todd Oil Services (1982) which overstated the sand content. Accordingly, Lock (1985) concluded that this well intersected the thickest and most sand-rich interval of Moki Formation implying the well was located in a proximal position. Observations by de Bock et al. (1991) of the wireline logs, cuttings descriptions and sidewall cores show that there is less than $10 \%$ sandstone in this well. At Hochstetter-1, the most distal well in this data set, only a very thin interval of fine-grained sediments is present. Accordingly, it is interpreted that the fan system of the Moki Formation did not extend this far to the northwest.

Occasional intra-Manganui Formation sandstones occur above the Moki Formation indicating that small sand influxes were still occurring into the basin within the dominantly fine-grained sediment. These sandstones are thin (generally less than five metres thick), typically fining-upwards and are not correlatable between wells, with the exception of the M2A Sandstone in the Moki-Maari area.

Sandstones of the S1/Sw Sandstone are present from North Tasman-1 northward. These sandstones are thick and tabular in the Maui Field and are better developed in the Tui-1 well to the northwest (New Zealand Overseas Petroleum Ltd, 2003). At Tui-1 five tabular sandstones and one interbedded fining upwards sandstone are documented from the wireline logs ranging from $2.5 \mathrm{~m}$ to $16 \mathrm{~m}$ in thickness (New Zealand Overseas Petroleum Ltd, 2003). This is likely to represent deposition in a central fan lobe but is noticeably farther north than central areas of the Moki Formation fan system, again providing further evidence for Miocene sediment progradation to the north or northwest. Seismic profiles show the reflectors of these sandstones to be heavily channelised in places, and amplitudes fade away from the well, suggesting a change from sandy to muddy lithologies (see Chapter 4).

\subsection{Well correlations}

\subsubsection{Methods}

Three well correlations were made for the Altonian to Waiauan aged sediment in the 13 key wells. Well Correlation 1 (Figure 5.7) trends south to north from Motueka-1 to Maui3, Well Correlation 2 (Figure 5.8) trends southeast to northwest from Motueka-1 to Hochstetter-1, and Well Correlation 3 (Figure 5.9) transverses the fan system from Te Whatu-2 to Moki-1, connecting Well Correlations 2 and 3. 
Approximate stage boundaries were projected along these three correlations. Because vertical sample spacing is coarse (50 - $100 \mathrm{~m}$ sample spacing) the stage boundaries are often poorly constrained. Most of the biostratigraphy for these 13 wells have been revised since the original reports were made, however, the various ages of the reports may also influence results, as knowledge of biostratigraphic datums improve with time. Maui-1, for example, has not been revised since the original biostratigraphy report in 1969 in which no sample-by-sample detail was presented. At individual wells, any given boundary was consistently put at the highest sample recording the older stage so that the stage boundary may move up to the next sample but not down. Thus, the error of the stage boundary is typically not more than the sample spacing. Correlating these stage boundaries between wells shows a general thinning of sediment package northward, but locally there are fluctuations between wells, most likely reflecting issues with sampling spacing or absence of diagnostic fauna, rather than dramatic sediment thickness variations. As de Bock et al. (1991) noted, biostratigraphic data over the Mid Miocene in Taranaki do not allow the definition of biozones to be correlated confidently.

Correlation between wells over the large area was done with a depositional model in mind. Following the discussion in Chapter 2, density currents transport sediment to the fans from the shelf, usually during low stands. Large high-density flows deposit sheet sandstones which grade laterally to more distal, fining-upwards turbidites, whilst smaller flows will be constrained to distributary channels on the fan surface, depositing their load on supra fans. Slight positive sea-floor relief from the previous fan lobe leads to compensational fan lobe switching (de Bock, 1994). Muds are deposited during quiescent times over the entire region. Major periods of sandstone deposition are represented as thick amalgamated sandstone bodies bounded by major mudstone units. Following this, major mudstone intervals between packages of amalgamated sandstone were correlated between wells with the aid of seismic profiles where possible (see de Bock et al., 1991). It is pertinent to note that whilst amalgamated sandstone packages appear to correlate over large distances, individual sandstone beds do not. Wireline log correlations of deepwater sandstones are non-unique; a number of solutions are possible. In the Moki Formation, this was clearly illustrated by de Bock et al. (1991) who presented five possible correlations over the top 80 $\mathrm{m}$ of Moki Formation between the closely spaced Moki-1 and Moki-2A wells $(2.5 \mathrm{~km}$ apart). It is possible that none of these correlations are true.

Where seismic quality allowed, correlation was aided by seismic profiles, particularly within the Maui-3D survey. Unfortunately, between many wells, seismic quality was not 
sufficient to correlate reflectors confidently between wells. Correlating to the Western Stable Platform proved particularly difficult as major faults had to be crossed and both seismic and wireline log character changed markedly between the central area and the Western Stable Platform. As there is no distinct Moki Formation on the Western Stable Platform, a number of alternative correlations proved possible. With distance, thick tabular sandstone packages grade to fining-upwards, muddy sandstone packages and eventually to mudstone. This lateral variation in lithology poses further problems for accurately defining formation boundaries.

The well correlations presented in Figure 5.7, Figure 5.8 and Figure 5.9 show one solution that complies with lithostratigraphic, chronostratigraphic, and depositional framework and has been constrained in some places by seismic correlation.

\subsubsection{Results and discussion}

Well Correlation 1 (Figure 5.7) shows the oldest sandstones of the Mid Miocene are Upper Altonian and were intersected by the Moki-1 and Maui-4 wells. These sandstones do not correlate to other wells, suggesting they were deposited over a geographically small area, perhaps due to localised subsidence in the Maui-4 / Moki area, or due to the overall shallower water depths prior to the bathymetric deepening in the Clifdenian. During the Clifdenian, the blocky sandstones of the Moki Formation are prevalent in the southern wells (e.g. North Tasman-1, Maui-4) and only spiky log motifs are observed in the northern wells (e.g. Kea-1, Maui wells). The backstepping of sandstones from Moki-1 to Tasman-1 in Altonian- to Clifdenian-aged sediment may be explained by bathymetric deepening throughout the study area at this time. Most of the Moki Formation sands were deposited during the Early Lillburnian, with the tabular sandstones deposited progressively further northward. Above the Moki Formation, sediment is dominated by mudstone with localised sandstones identified in the Moki-1 (M2A Sandstone), Kea-1 and Maui-1 wells. The $\mathrm{S} 1 / \mathrm{Sw}$ Sandstone is present in the Maui wells, but seismic interpretation suggests that the sandstones of this unit are not correlatable between the Maui wells.

Well Correlation 2 (Figure 5.8) shows a dramatic thinning of Mid Miocene sediments to the northwest. The Altonian-aged sediment thins to the north-westward and is not present as far as Pukeko-1, Kiwa-1 and Hochstetter-1 wells. Clifdenian-aged sediment again thins to the northwest but is present farther into the basin, identified in the Pukeko-1 and Kiwa-1 wells. Lillburnian and Waiauan-aged sediment follows this trend of progressive north- 
westwards sediment deposition. This reflects a significant supply of terrigenous sediment from the south which progrades into the basin to the north.

On Well Correlation 2, the blocky sandstone motif that is typical of central Moki Formation was only identified on the Tasman-1 and North Tasman-1 well logs. Fining upwards motifs were observed in Te Whatu-2, and irregular motifs seen in Pukeko-1 implying a north-westward change from central fan facies to progressively more distal fan.

Thin sandstones within the Manganui Formation are common on wireline logs on the north-western wells (Te Whatu-2, Pukeko-1, Kiwa-1 and Hochstetter-1). These sandstones are not correlatable between wells; seismic character suggests that these sands cover only a small geographic area. There does not appear to be a pattern of sandstone distribution within the mudstone, but that small sand influxes continued to occur throughout the Mid Miocene after deposition of the Moki Formation.

Well Correlation 3 (Figure 5.9) connects the Well Correlations 1 and 2 and was constructed primarily to better define the Moki Formation in the Te Whatu-2 well. Altonian-aged sediment thin towards Te Whatu-2, but the Clifdenian and Lillburnian sediment thicknesses are comparable between Te Whatu-2, Maui-4 and Moki-1. The Waiauan sediment is thicker at Te Whatu-2 than both Maui-4 and Moki-1. In addition, more sandstones are identifiable on the Te Whatu-2 gamma ray log, above the Moki Formation than in the Maui-4 and Moki-1 wells. This implies a slight migration of sediment depocentres westward during the Mid Miocene, caused by either, or a combination of, slope progradation toward the west or relative subsidence in the western area. 


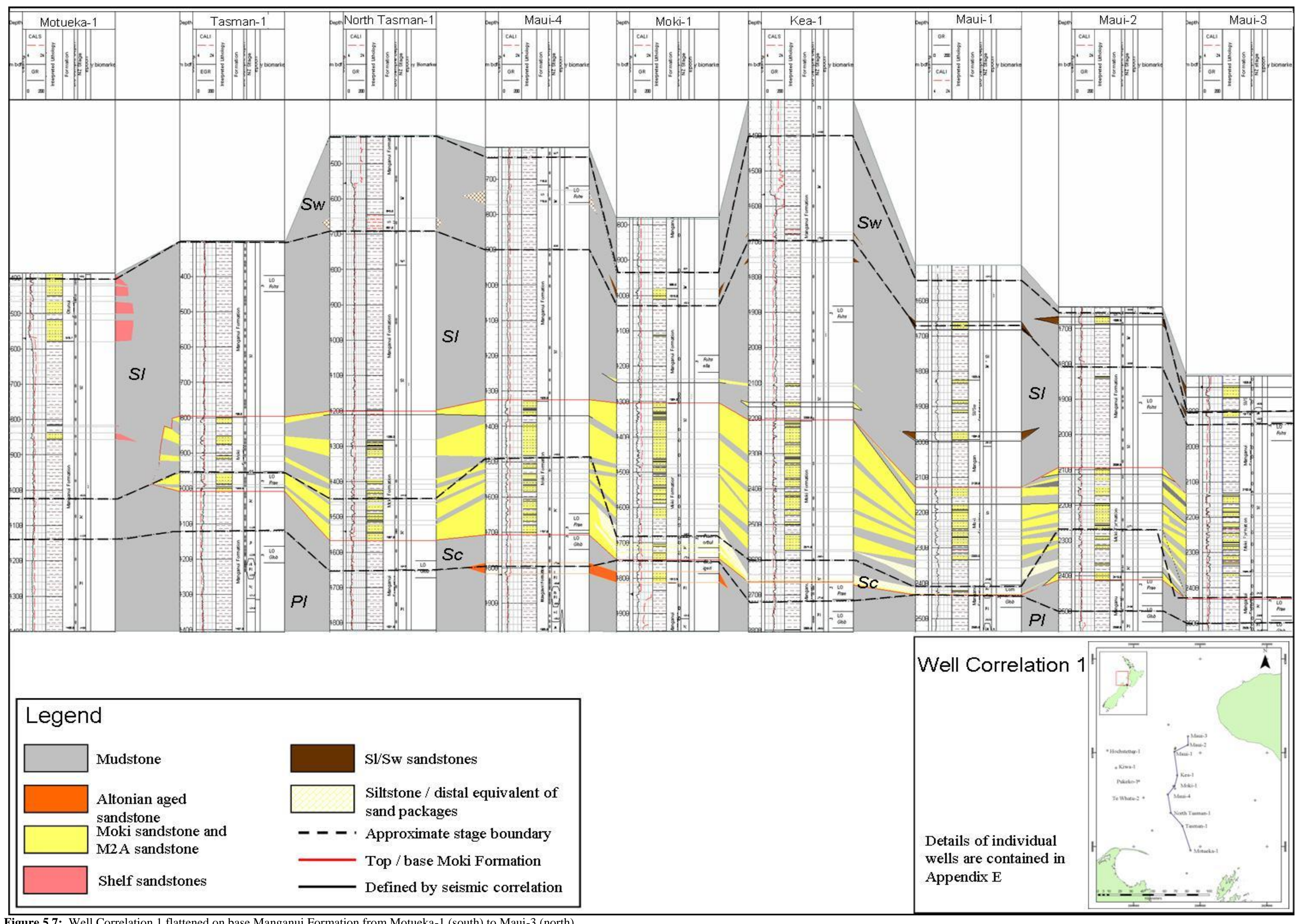

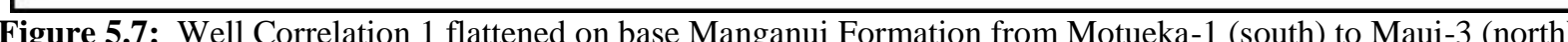




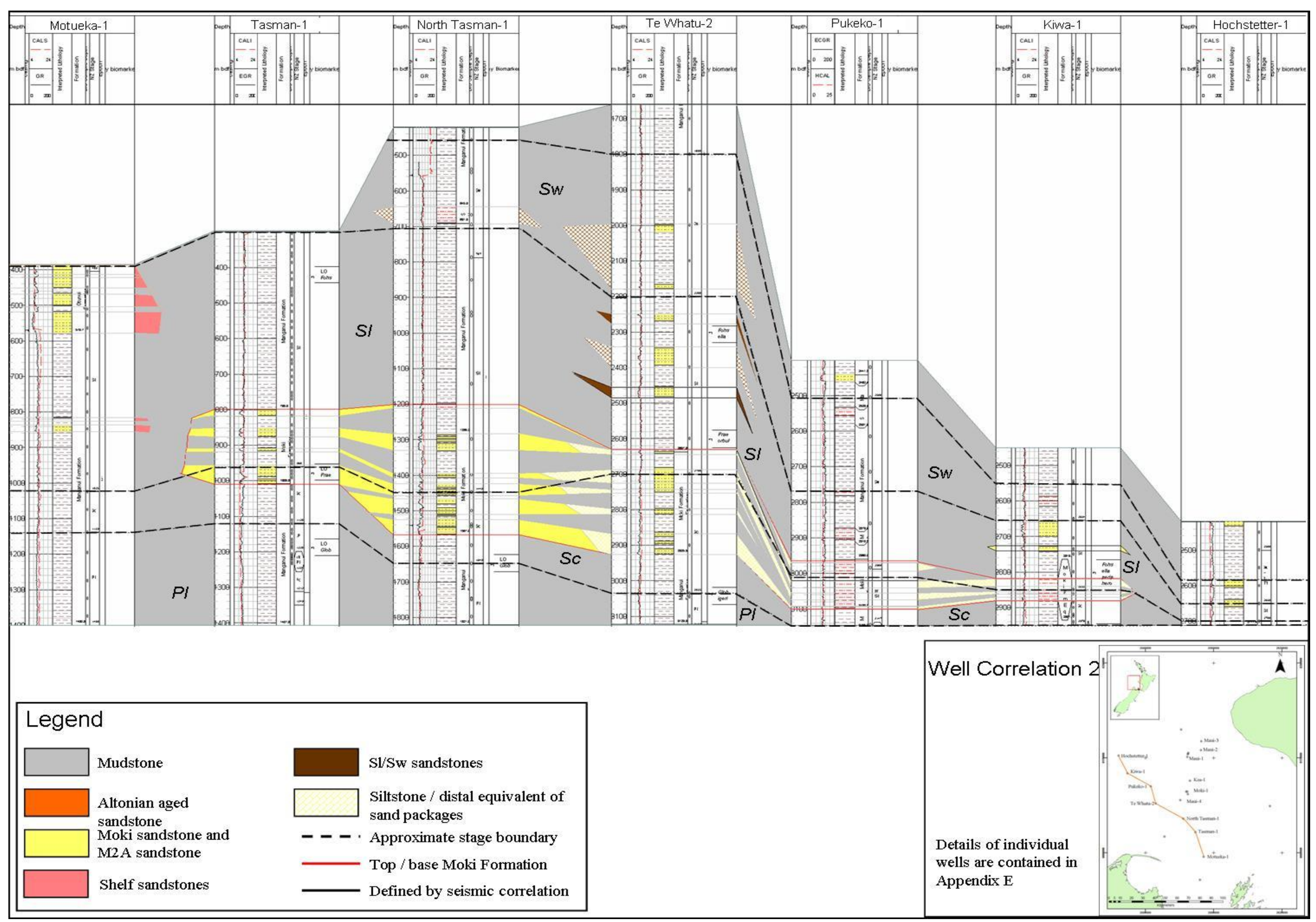

Figure 5.8: Well Correlation 2 flattened on base Manganui Formation from Motueka-1 (southeast) to Hochstetter-1 (northwest) 


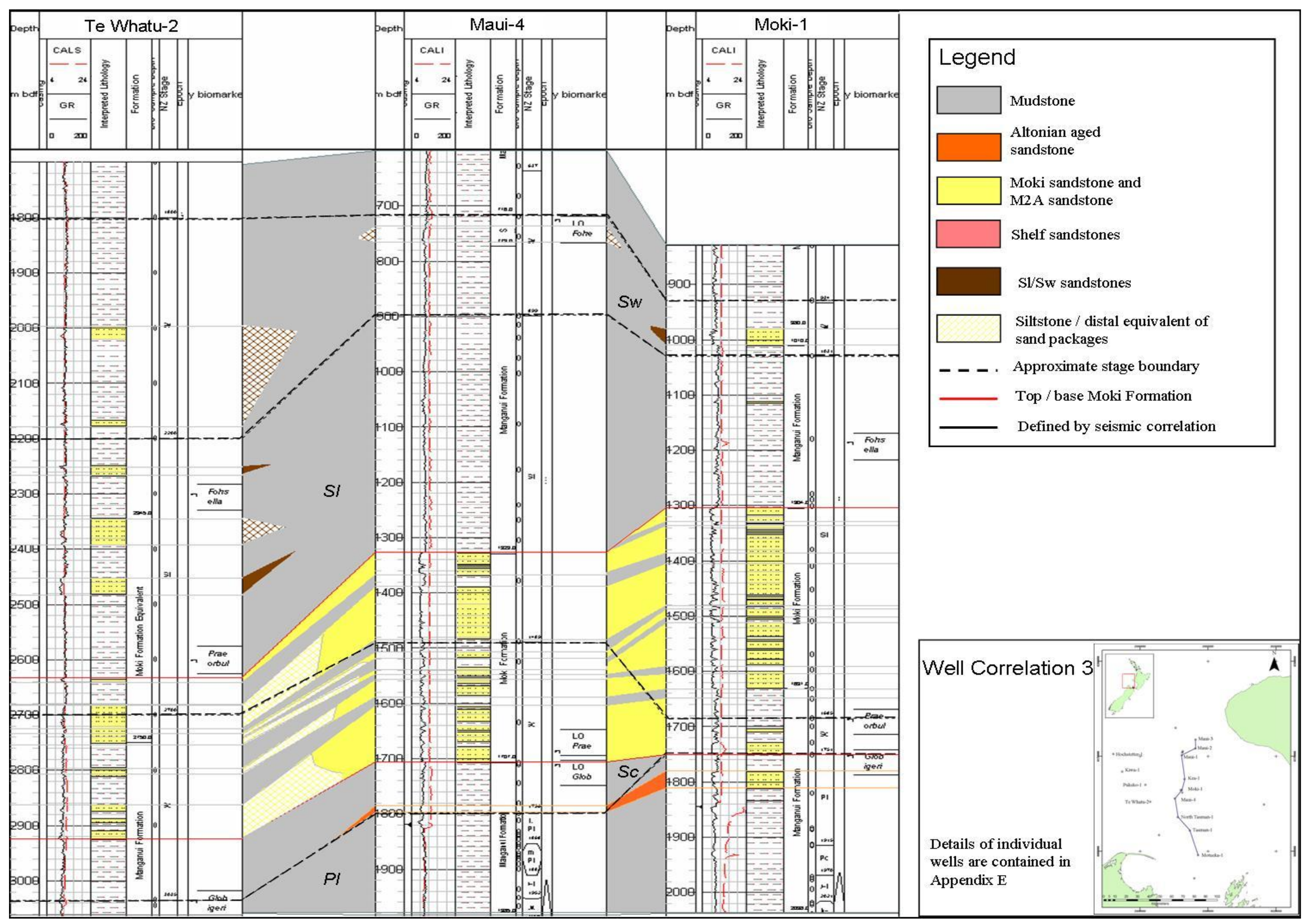

Figure 5.9: Well Correlation 3 flattened on base Manganui Formation between Te Whatu-2, Maui-4 and Moki-1 


\subsection{Summary}

Mid Miocene sediments prograded into the basin from the south, building out the shelf and spreading basin-floor sandstones progressively farther north-westward. The earliest sands supplied to the basin during the Late Altonian were deposited in the vicinity of Moki-1. This localised deposition may be due to a bathymetric low in a central area at the time (c.f. de Bock, 1994), possibly related to the infilling basin foredeep, or to generally shallower water depths prior to the Clifdenian deepening. The central fan of Clifdenian-aged sands was penetrated by the southern-central wells from Tasman-1 to Moki-1. Tabular sandstones were deposited progressively farther northwards to the Maui Field during the Lillburnian, as the system prograded. Clifdenian and Early Lillburnian-aged sediment spread as far west as Kiwa-1 but did not reach Hochstetter-1.

Sandstones were replaced by finer-grained sediment after the deposition of the Moki Formation, with minor sands deposited locally, particularly on the Western Stable Platform. A further sandy influx occurred from Latest Lillburnian to Waiauan ( $\mathrm{S} 1 / \mathrm{Sw}$ Sandstone) with the main sandstone depocentre located to the northwest of the Maui Field. These sandstones are less continuous than the Moki Formation and are heavily channelised. 


\subsection{Core facies}

\subsection{Introduction}

Conventional drill cores provide a direct record of the sedimentology of the penetrated rock at a much higher resolution than indirect methods such as seismic or wireline logs and can therefore be used for detailed lithofacies analyses. From objective observation and description of facies, their associations and successions, and the subsequent applications of these to a well-established facies model, the depositional systems can be characterised (e.g. Walker, 1992b).

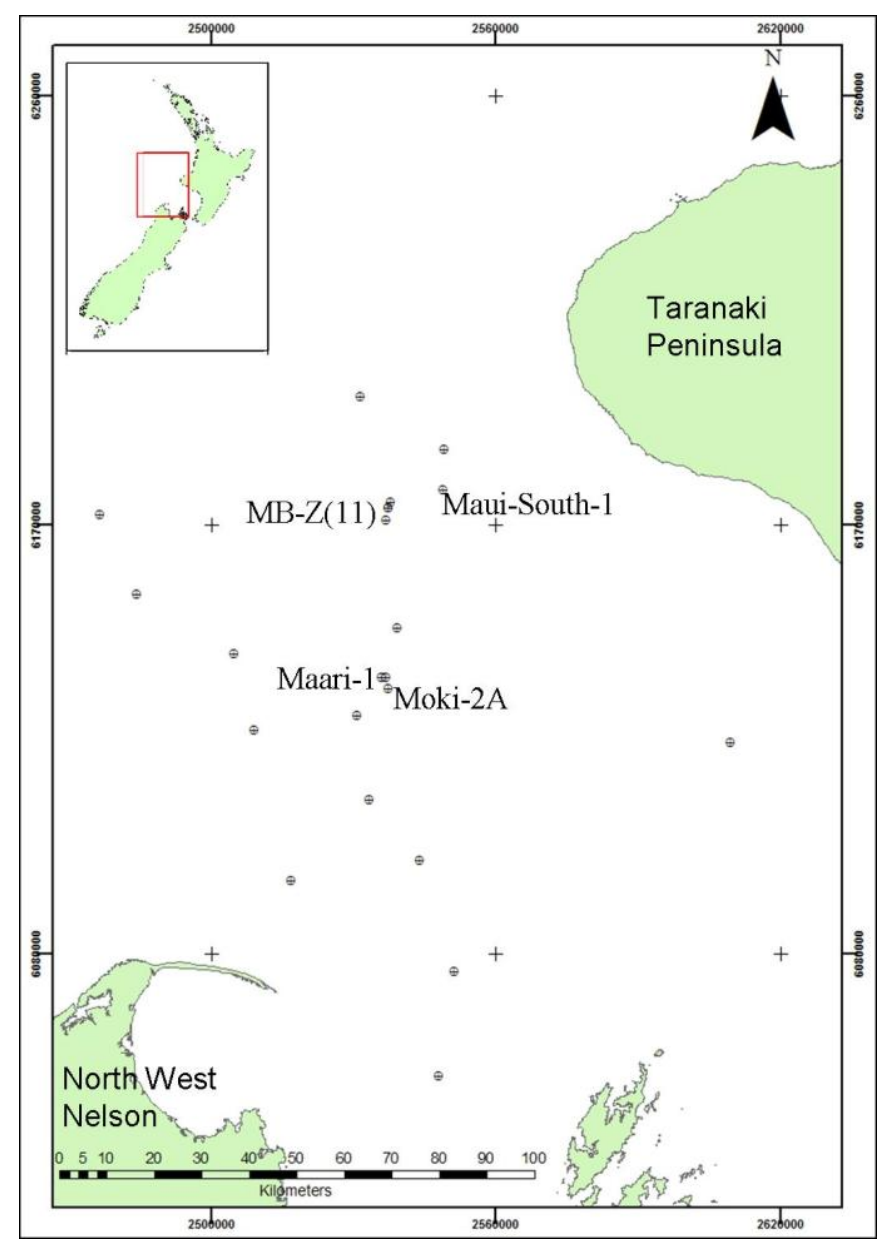

Figure 6.1: Map showing the location of wells with conventional drill cores looked at in this study.

Unfortunately, due to the expensive and time-consuming nature of coring, only a few conventional drill cores have been recovered from the Moki Formation and only three have been recovered within the study area. These were in Maui South-1, MB-Z(11) and Maari1 (Figure 6.1). One conventional drill core was recovered in the Moki-2A well through the M2A sand and Manganui Formation mudstone above the Moki Formation. Onshore, 
outside the study area, the Moki Formation has been cored in several wells (Cardiff-1, Durham-1, Kaimiro-2, Kaimiro-3, Kapuni-1, Kapuni-9 and Midhurst-1). Analyses, including sedimentology, petrology, porosity, permeability and grain density, have previously been conducted on these cores and are contained within open file petroleum reports (Appendix B).

Representative intervals of typical Moki Formation units were selected from core photographs in well completion reports. These were the intervals 1306 to $1309 \mathrm{~m}$ and from 1323 to $1329 \mathrm{~m}$ in Maari-1, 2304 to $2308 \mathrm{~m}$ in Maui South-1, 1262 to $1265 \mathrm{~m}$ in Moki-2A and 2132 to $2135 \mathrm{~m}$ in MB-Z(11). Core from MB-Z(11) and Moki-2A were contained in $90 \mathrm{~cm}$ long cardboard boxes and were generally of poor quality with much of the sand disaggregated. An initial observation of core intervals from these wells suggested that the facies are similar to those observed in Maari-1 and Maui South-1, so only 1262 to $1263.13 \mathrm{~m}$ and 1264.98 to $1265.81 \mathrm{~m}$ in Moki-2A and 2132.9 to $2133.8 \mathrm{~m}$ in MB-Z(11) were described and photographed.

Conventional drill cores from Maari-1 and Maui South-1 were viewed under natural light and wetted to best show the sedimentary features. As the Moki-2A and MB-Z(11) cores were in poor condition and contained in cardboard boxes they were viewed indoors under artificial, florescent lighting and not wetted. Photographs of each core section were taken and each core was described in detail (see Appendix F). Detailed sedimentological descriptions identified several lithofacies, which are outlined in this chapter and summarised in Table 6.1. All depths referred to in this chapter are Along Hole Below Drilling Floor (AHBDF).

\subsection{Lithofacies}

Five facies were identified based on sedimentological descriptions and photographs from the observed cores. These facies were massive sandstone, fining-upwards laminated sandstone, finely interbedded / laminated mudstone and sandstone, massive mudstone and mottled mudstone. These facies are summarised in Table 6.1. 


\begin{tabular}{|c|c|c|c|}
\hline Facies & Facies code & Description & Interpretation \\
\hline $\begin{array}{l}\text { Massive } \\
\text { sandstone }\end{array}$ & MS & $\begin{array}{l}\text { Light brown, generally fine to very fine- } \\
\text { grained, well-sorted sandstone, with } \\
\text { occasional large ( } 2 \mathrm{~mm}) \text {, rounded, rust } \\
\text { rimmed grains, and elongated mud } \\
\text { clasts } 1-2 \mathrm{~cm} \text { in length. }\end{array}$ & $\begin{array}{l}\text { Freezing sedimentation / } \\
\text { rapid suspension, } \\
\text { sedimentation by high- } \\
\text { density current. Central fan- } \\
\text { lobe. }\end{array}$ \\
\hline $\begin{array}{l}\text { Fining upwards } \\
\text { laminated } \\
\text { sandstone }\end{array}$ & LS & $\begin{array}{l}\text { As for massive sandstone but becomes } \\
\text { muddier, more laminated and } \\
\text { carbonaceous upwards. Laminations } \\
\text { are both planar and undulating. }\end{array}$ & $\begin{array}{l}\text { Upper (planar laminated) } \\
\text { and lower (ripple laminated) } \\
\text { flow regime from low-density } \\
\text { waning flow of density } \\
\text { current. }\end{array}$ \\
\hline $\begin{array}{l}\text { Finely interbedded } \\
\text { / laminated } \\
\text { mudstone and } \\
\text { sandstone }\end{array}$ & IMS & $\begin{array}{l}\text { Dark grey mudstone, often very } \\
\text { carbonaceous, finely interbedded or } \\
\text { laminated (on mm to cm scale) with } \\
\text { brown very fine sandstone. Thin } \\
\text { carbonaceous layers are often present. } \\
\text { Interbed contacts are often sharp and } \\
\text { irregular. }\end{array}$ & $\begin{array}{l}\text { Traction and suspension } \\
\text { sedimentation by low-density } \\
\text { waning flow of density } \\
\text { current. Lobe fringe of } \\
\text { density current deposit. }\end{array}$ \\
\hline Massive mudstone & MS & Dark grey massive mudstone. & $\begin{array}{l}\text { Suspension sedimentation of } \\
\text { the distal part of a density } \\
\text { current and / or background } \\
\text { pelagic and hemipelagic } \\
\text { sedimentation. }\end{array}$ \\
\hline Mottled mudstone & $\mathrm{BM}$ & $\begin{array}{l}\text { Dark grey mudstone, disrupted by } \\
\text { pockets and irregular lenses of light } \\
\text { grey, usually very fine sandstone. } \\
\text { Occasional pockets of very coarse sand } \\
\text { to grit and shell fragments occur. } \\
\text { Mottling often occurs in concentrated } \\
\text { zones. Often in occurs up to } 50 \mathrm{~cm} \\
\text { thick. }\end{array}$ & $\begin{array}{l}\text { Massive mudstone that has } \\
\text { been subsequently } \\
\text { bioturbated, reworked and / } \\
\text { or slumped. }\end{array}$ \\
\hline
\end{tabular}

Table 6.1: Summary of core facies based on sedimentological descriptions and photographs from observed core intervals within Maari-1, Maui South-1, MB-Z(11) and Moki-2A.

\subsubsection{Massive sandstone (MS)}

Massive sandstones of the Moki Formation are light brown to white grey in colour, generally fine to very fine-grained sandstone, rarely medium-grained, well-sorted, with occasional large (up to $2 \mathrm{~mm}$ ), rounded, rust rimmed grains, and elongated mud clasts 1 to $2 \mathrm{~cm}$ in length (Figure 6.2). At the base of some massive sandstones is muddy sediment similar to the underlying strata. In Maui South-1, some wispy, non-planar, dark micaceous and / or carbonaceous laminations were seen within the massive sandstone. The sandstone 
is sometimes soft causing the core to be biscuited, broken, or even as loose sand (e.g.

Moki-2A). This facies may be a few centimetres to several metres thick and usually has a sharp basal contact with underlying facies and the upper contact may be sharp or may grade into the fining-upwards, laminated sandstone or the finely interbedded mudstone and sandstone facies.

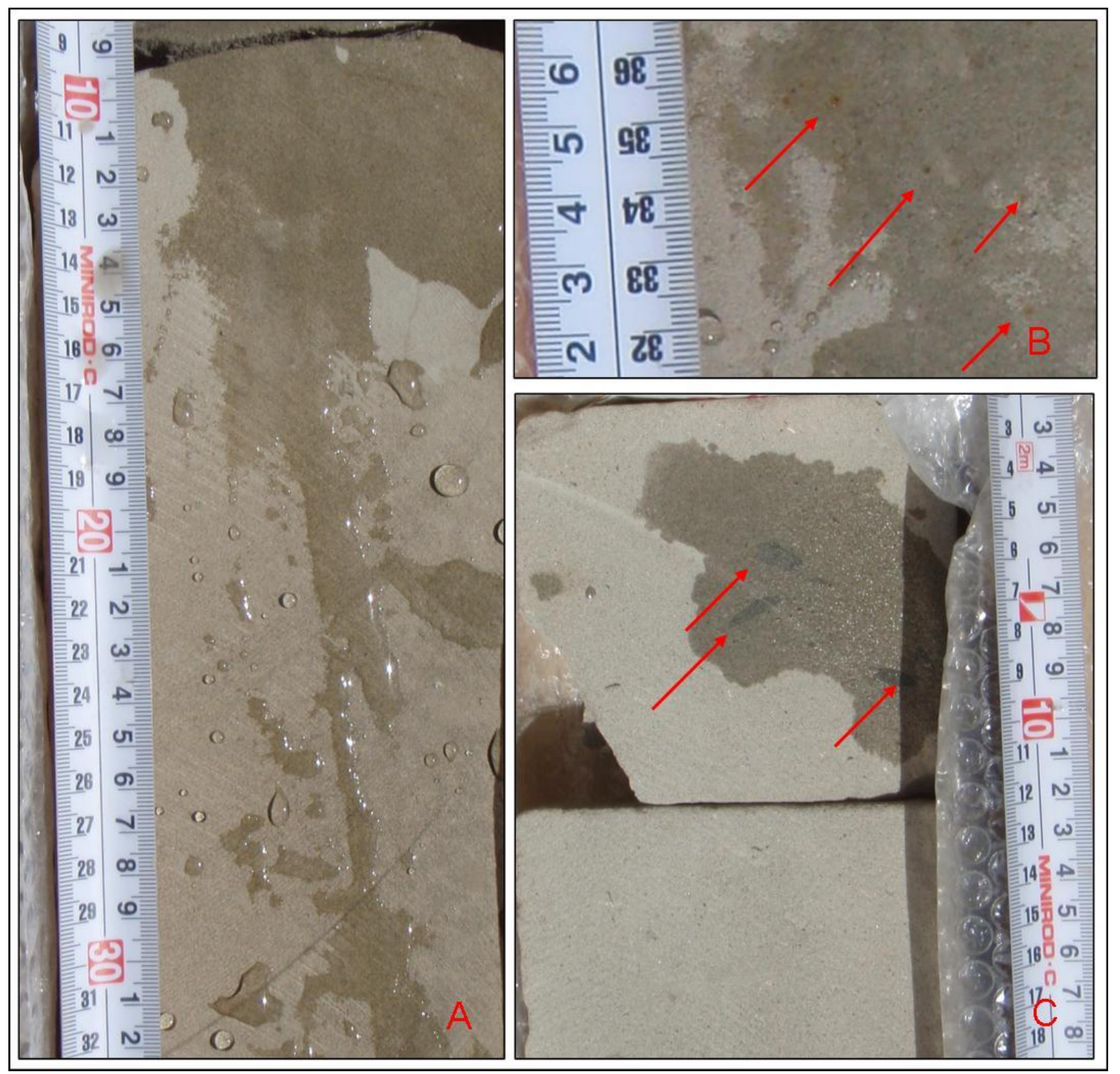

Figure 6.2: Examples of massive sandstone facies. (A) Massive sandstone from Maari-1 1328.085$1328.35 \mathrm{~m}$. (B) Five centimetres of massive sandstone with scattered larger rusty grains indicated by red arrows, from Maari-1 1308.83 - 1308.88 m. (C) Mud clasts, indicated by red arrows, randomly orientated within massive sandstone from Maari-1 1326.02 - $1326.185 \mathrm{~m}$.

\subsubsection{Fining-upwards, laminated sandstone (LS)}

The fining-upwards, laminated sandstone is similar to the massive sandstone but becomes finer grained, less well sorted, more laminated and carbonaceous upwards (Figure 6.3). 
Laminations are both carbonaceous and micaceous in nature and are often wispy, irregular and occasionally planar. This facies usually occurs at the top few centimetres of the massive sandstone facies, with the contact between the facies very gradational. This facies may be capped by the finely interbedded mudstone and sandstone, or massive mudstone facies.
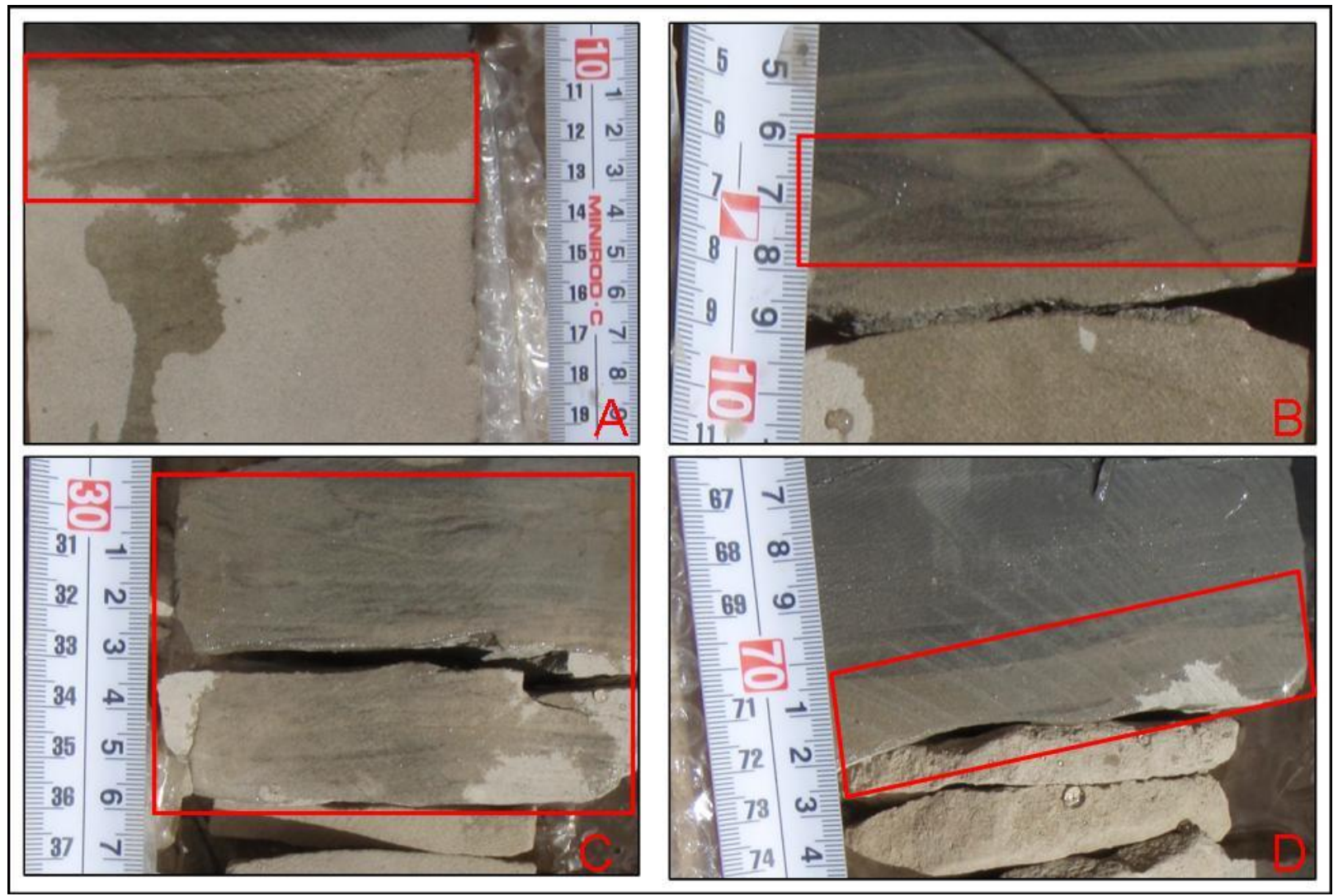

Figure 6.3: Examples of fining-upwards laminated sandstones (indicated by the red boxes). (A) Finingupwards sandstone with increasing carbonaceous laminations towards the top, from Maari-1 1307.095 to $1307.20 \mathrm{~m}$. (B) Heavily laminated sandstone with dark non-planar laminations from Maari-1 1328.04 to $1328.11 \mathrm{~m}$. (C) Increasingly laminated fining-upwards sandstone from Maari-1 1327.29 to $1327.375 \mathrm{~m}$. (D) Fining-upwards sandstone with dark lenses from Maari-1 1327.66 to $1328.74 \mathrm{~m}$.

\subsubsection{Finely interbedded / laminated mudstone and sandstone (IMS)}

The finely interbedded mudstone and sandstone facies is dominated by dark grey, carbonaceous mudstone, which is finely interbedded ( $\mathrm{cm}$ scale) or laminated ( $\mathrm{mm} \mathrm{scale}$ ) with subordinate light brown, very fine sandstone (Figure 6.4). Thin carbonaceous laminations are often present. Interbeds may be parallel but are more commonly irregular; ripple laminations, cross-bedding and other sedimentary structures are present. Contacts between the beds are often sharp and irregular. The basal contact of this facies is typically gradational with either the massive sandstone or fining-upwards laminated sandstone. This facies may grade into either the massive or mottled mudstone facies. 


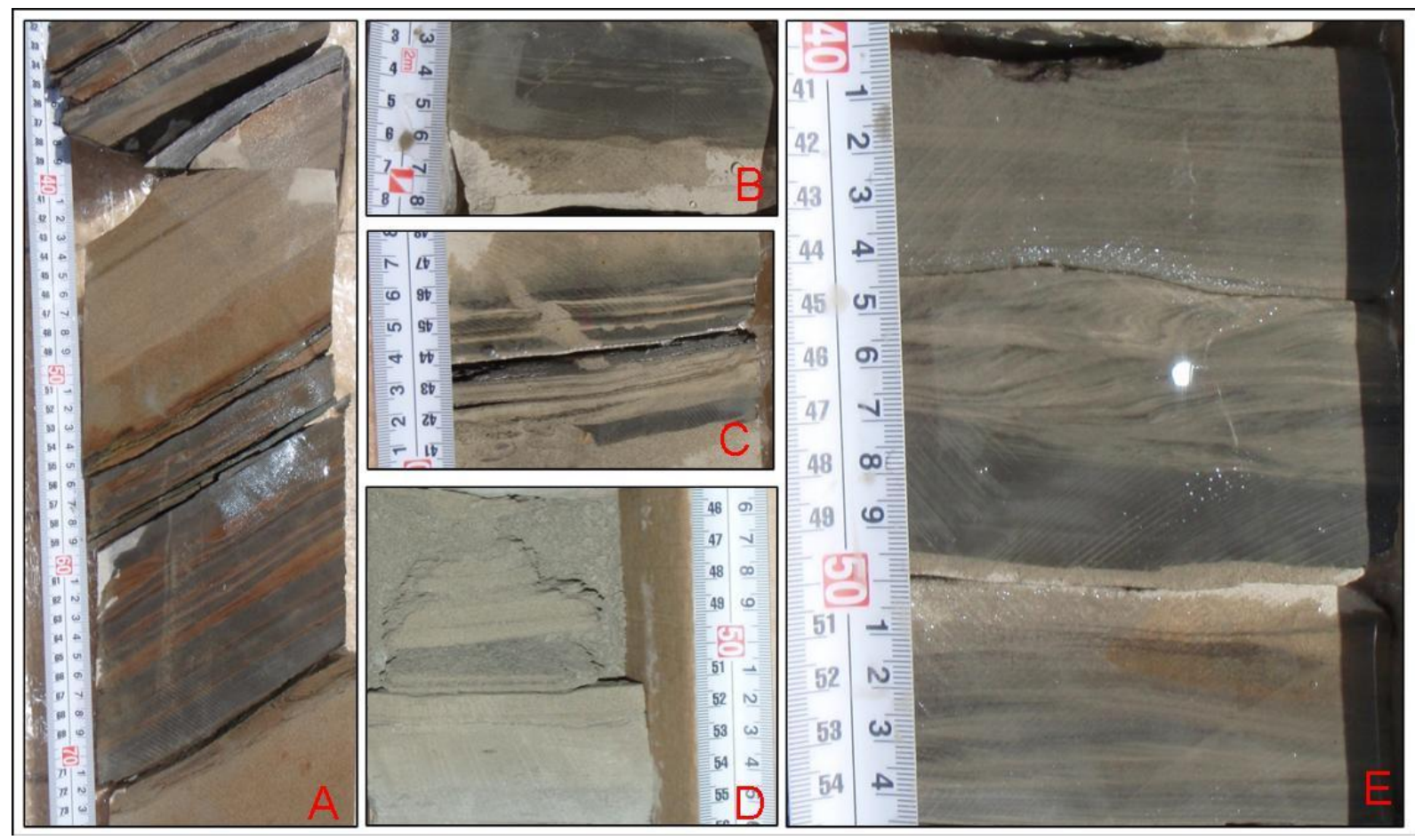

Figure 6.4: Examples of the finely interbedded / laminated mudstone and sandstone facies. (A) Finely interbedded mudstone and sandstone from MB-Z(11) 2304.32 - 2304.75. (B) Mudstone with sandstone cross bedded laminations from Maari-1 1327.02 - 1327.085 m. (C) Laminated mudstone and sandstone from Maari-1 1308.52 - $1308.60 \mathrm{~m}$ (note the scale round the wrong way). (D) Mudstone and sandstone laminations from Moki-2A (M2A sand) $\sim 1262.5 \mathrm{~m}$. (E) Climbing ripples, convolute and planar bedding from Maari-1 1328.395 - $1328.54 \mathrm{~m}$.

\subsubsection{Massive mudstone (MM)}

The massive mudstone facies was uncommon in the cores observed (Figure 6.5). It consists of a dark grey massive mudstone and is usually very thin ( mm to a few $\mathrm{cm}$ thick) as thicker mudstones appear to be heavily bioturbated and reworked (see mottled mudstone below). This facies usually has a gradational lower contact with finely interbedded sandstone and mudstone or fining-upwards, laminated sandstone facies and a sharp upper contact with massive sandstone.

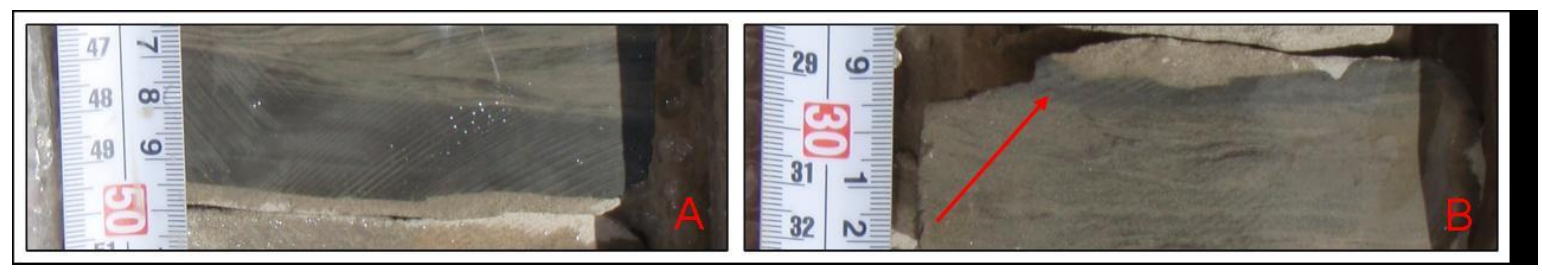

Figure 6.5: Examples of uniform mudstone facies from (A) Maari-1 1328.465 - $1328.51 \mathrm{~m}$ (B) Maari-1 1327.275 - $1327.325 \mathrm{~m}$ (arrow points towards uniform mudstone facies). 


\subsubsection{Mottled mudstone (BM)}

Mottled mudstones of the Moki Formation are characterised by a dark grey mudstone, disrupted by pockets and irregular lenses of light grey, very fine sandstone and occasional pockets of very coarse sand to granules and shell fragments occur in places (e.g. Figure 6.6A). Mottling typically occurs in concentrated zones of $\sim 5-10 \mathrm{~cm}$ and the entire facies may be present in relatively thick units in the order of 10-80 cm. Angular discordances within undulose laminations are occasionally present in the thick mudstone packages (e.g. Figure 6.6B) and may have been caused by slumping. One cemented concretion $(\sim 10 \mathrm{~cm}$ in diameter) was cored in Maari-1 within this facies package (e.g. Figure 6.6C).

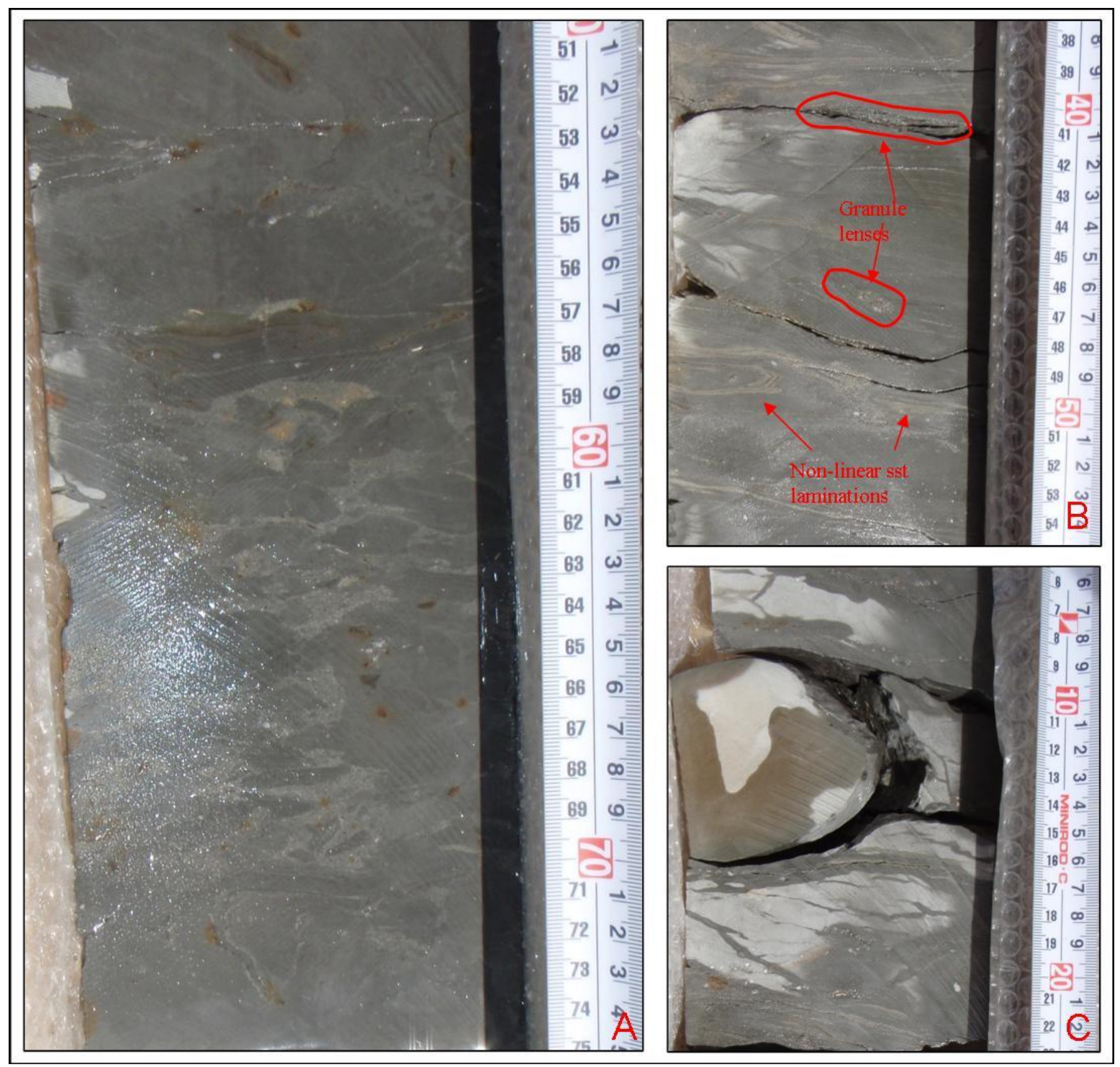

Figure 6.6: Examples of mottled mudstone facies. (A) Mottling of fine-grained sandstone, with occasional coarse grains, within dark grey mudstone, rust staining present throughout, from Maari-1 1323.50 - 1323.75 m. (B) Non-linear sandstone laminations and lenses of very coarse sandstone within mudstone, from Maari11324.37 - $1324.55 \mathrm{~m}$. (C) Concretion between 9 and $16 \mathrm{~cm}$ within mottled mudstone, from Maari-1 $1324.055-1324.23 \mathrm{~m}$ 


\subsection{Facies associations}

The Moki Formation is greater than $300 \mathrm{~m}$ thick throughout the Moki-Maari area (321 m in Maari-1) and covers an area of approximately $5000 \mathrm{~km}^{2}$. In total, only $92.3 \mathrm{~m}$ of $51 / 4$ " diameter core has been recovered from the Moki Formation in the Maari-1, Maui South-1 and MB-Z(11) wells with an additional $65 \mathrm{~m}$ recovered from the overlying Manganui Formation in Moki-2A. In this study, $13.9 \mathrm{~m}$ of Moki Formation and $1.93 \mathrm{~m}$ of M2A Sandstone and Manganui Formation core was subjectively chosen for identifying, describing and illustrating the lithofacies discussed above. It is therefore recognised that the core intervals observed and described may not be truly representative of the Moki Formation as a whole. From the core intervals of the Moki Formation that were observed repeated facies associations are identifiable, and are supported by previous descriptions in open-file reports.

Where conformable, massive sandstone grades over a short interval into thin finingupwards, laminated sandstone, which in turn grades into finely interbedded mudstone and sandstone, which finally grades into either massive or mottled mudstone. Both the basal and upper contacts of this association are sharp and often undulating. An example of several fining-upwards associations $(\sim 15-30 \mathrm{~cm}$ each $)$ is illustrated in Figure 6.7. Not all facies may be present in one association and facies associations are commonly disrupted by sharp contacts.

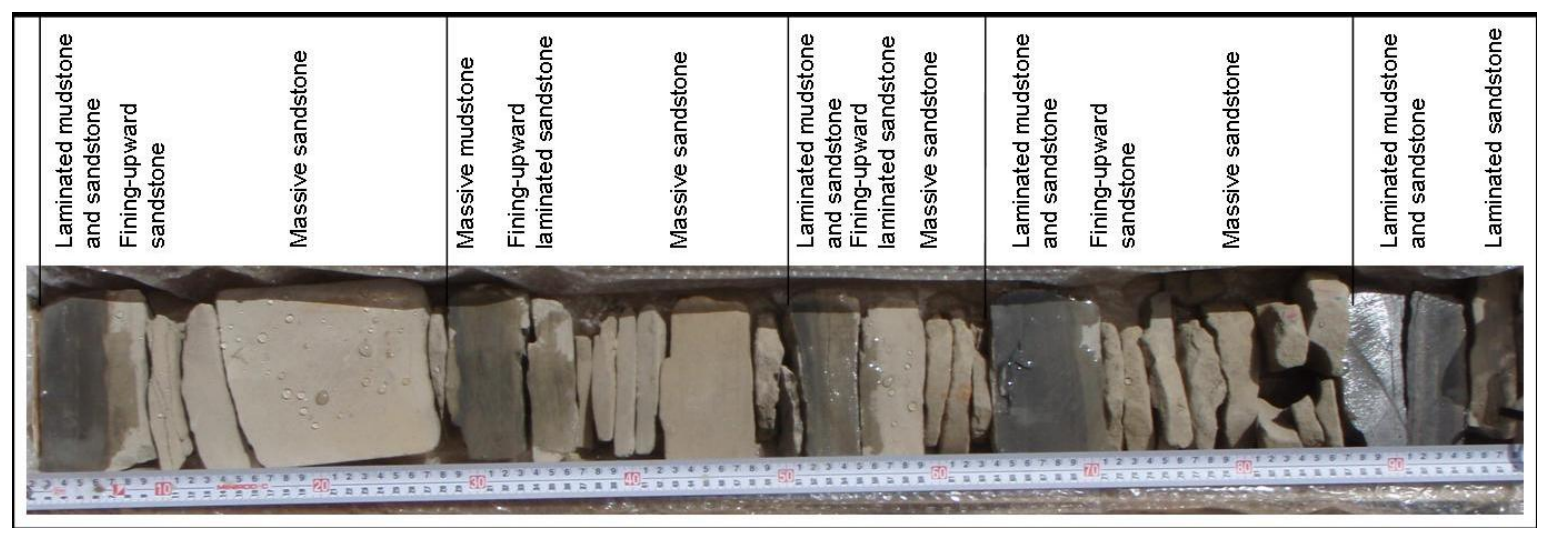

Figure 6.7: Typical fining-upwards facies association seen within a one metre interval of the Moki Formation. Core photograph of Maari-1 $1327-1328 \mathrm{~m}$.

In addition, massive sandstones were also observed to alternate with mottled mudstones, separated by sharp, planar or slightly undulating contacts as illustrated in Figure 6.8. 


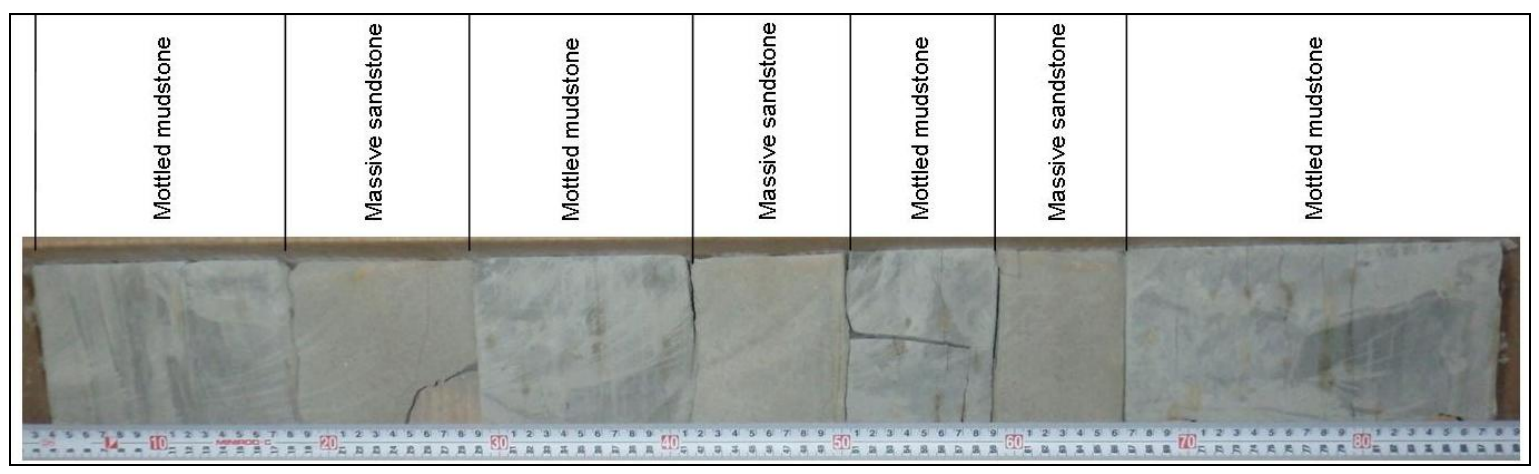

Figure 6.8: Example of interbedded massive sandstone and mottled mudstone facies with sharp upper and basal contacts. Core photograph of MB-Z(11) $2132.9-2133.8 \mathrm{~m}$

Steeply dipping $\left(\sim 30^{\circ}\right)$, curved, sharp contacts observed in the Maari-1 core could be the result of small channelisation on the fan's surface. This was seen cutting into massive sandstone, infilled with mottled mudstone, which in turn showed sharp, curved contact with sandstone above. This may providing evidence for small-scale channel incision on the pre-existing lobe surface, providing sediment by-pass routes for the next density current.

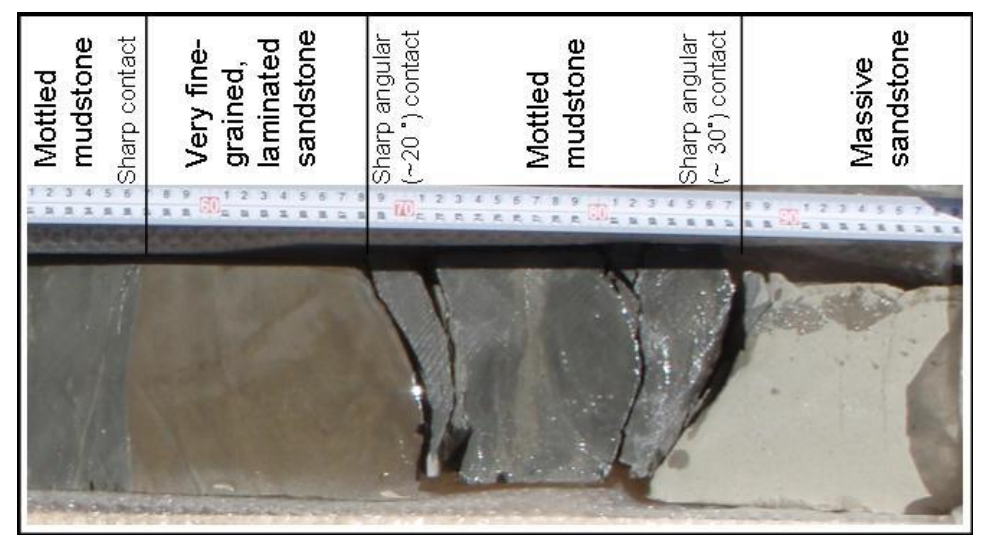

Figure 6.9: Example of channelisation indicated by the sharp angular contacts between different lithologies and the disrupted nature of the mudstone. Core photograph of Maari-1 1324.41 - $1324.99 \mathrm{~m}$.

\subsection{Interpretation}

The Moki Formation is comprised of stacked, interbedded sandstones and mudstones, which were deposited at mid- to lower-slope depths. Interpretations of each of the lithofacies identified are summarised in Table 6.1. The massive, well-sorted sandstones were probably deposited by high-density flows on a relatively flat basin-floor.

Corroborating evidence is provided by the presence of sparse coarse (rust-rimmed) grains, shell fragments, and mud clasts that would have been suspended in the dense flow. The sharp basal contact between the massive sandstone and underlying sediment suggests the 
density-current eroded sediment as it travelled over it. The muddy base of some massive sandstones could be the result of this erosion and mixing with the density flow sediment. The wispy, ripple laminations and higher mud content at the top of these sandstones (fining-upwards, laminated sandstone facies) suggest a change from suspension fall-out to traction-style deposition as the flow wanes (e.g. Lowe, 1982).

Core from Maui South-1 shows a dominance of thick massive sandstones up to several metres thick, which are generally thicker than other Moki Formation cores (Browne, 1999). Occasional horizons of coarse-grained sandstone are present in the otherwise massive, very fine- to fine-grained sandstone. There is also little evidence of bioturbation in this short core. These thick sandstones may represent amalgamated packages, comprising more than one high-density flow event. The reason for the absence of other lithofacies may be due to successive high-density currents, planing off the tops of the previous flows. The site is located very close to the Cape Egmont Fault (Figure 6.1), and Browne (1999) suggested that contemporaneous fault movement may have affected deposition of the Moki Formation at the Maui South-1 site, resulting in different sedimentology than other wells. Whilst this is possible, as previously mentioned, the amount of core recovered from the Moki Formation is minimal compared to the formation thickness and geographic extent, so it may be premature to consider the formation recovered in the Maui South-1 core as unusual.

The finely interbedded sandstone and mudstone facies shows the greatest evidence for traction sedimentation of bed loads such as ripple lamination and cross bedding, suggesting that this facies was deposited by low-density flows or by the dilute tail of high-density flows. This facies therefore may have been deposited on the lobe fringe.

The lack of coarse-grained sediment in the massive and mottled mudstone facies indicates quiescent conditions when the muds were deposited by suspension sedimentation from the distal part of density currents and / or as hemipelagic rain. Subsequent bioturbation of mudstone indicates low sediment supply to this location. Occasional deformed and discordant laminations observed provide evidence for slumping. Within the Mount Messenger Formation, slumped mudstones occurs stratigraphically beneath observed sequence boundaries, and have been interpreted as the result of oversteepening of the slope and outer shelf sediments during the highstand in sea level (King and Browne, 2001). From the descriptions by Browne (1998) of the Maari-1 core, the slumped siltstone appears 
to occur below massive sandstone beds, so it is possible that they have a similar origin as those in the Mount Messenger Formation, thus indicating early sea level lowstand deposits.

The overall fining-up facies association implies a depositional continuum from one density flow event where the bulk of sediment is rapidly deposited from the high-density flow, and as the flow becomes more dilute, sedimentation becomes dominated by bed-load traction forming planar and rippled lamination, and the sequence is finally capped by muds. In contrast, the alternating sandstone and bioturbated mudstone lithofacies association may reflect episodic sedimentation indicative of bypass and flow stripping where the dilute tails of high-density flows, which deposited the sands, have continued on down-flow.

Following this, the interbedded mudstones would represent quiescent background suspension deposition between flow events.

The lithofacies associations are likely to represent either one depositional event (where conformable and continuous) or a number of depositional events deposited over a relatively short period. Unfortunately, the lengths of core observed in this study were too short and discontinuous to identify depositional cycles. However, the total 65 metres of Maari-1 core was fully described by Browne (1998). From this, the author recognised three ( 40 m thick) depositional cycles over the entire length of the Maari-1 core. Only the top of the oldest cycle was cored, consisting of bioturbated mudstone. The second cycle was fully cored comprising (from bottom to top) thick-bedded massive sandstone which passes up into finely interbedded mudstone and sandstone and then into mottled mudstone. The base of the youngest cycle consists of thick-bedded massive sandstone with thin interbedded bioturbated mudstone. The author related each cycle to sea level transitions from relative low stand to high stand with massive sandstone accumulating on the basinfloor during the low stand, superseded by the deposition of generally thinner and finer facies as relative sea-level rises. During highstands deposition is dominated by pelagic or hemi-pelagic sedimentation.

The M2A Sandstone, cored in the Moki-2A well, comprises multiple sandstone units but overall has a lower net:gross sand ratio than the Moki Formation. The mudstones are again heavily bioturbated, implying a low sedimentation rate between density flows. There is a lack of the finely interbedded / laminated mudstone and sandstone facies (IMS). Seismic and wireline log correlation show that this sandstone is localised around the Moki-Maari area, which may explain why there is a lack of more distal deposits recovered from this core. The M2A Sandstone is interpreted to represent a further episode of density currents 
to the basin floor, but these lobes are generally less developed than those of the Moki Formation.

\subsection{Summary}

The Moki Formation, with high net:gross sandstone ratios, was deposited by high-density flows in mid- to lower-slope depths. Sediments grade upward from massive sandstone, to fining-upwards, laminated sandstone, to interbedded mudstone and sandstone, and finally to massive or bioturbated mudstone. This waning flow succession represents a change from deposition by rapid suspension sedimentation to traction sedimentation of bed-loads and finally to suspension sedimentation. In addition, alternations of massive sandstone and bioturbated mudstone are suggestive of episodic, rapid sediment influx and flow stripping. Steeply dipping, curved, sharp contacts seen in core are interpreted to be the result of small channel incisions on the fans surface, which would have distributed smaller density flows. 


\subsection{Palaeogeography and synthesis}

\subsection{Introduction}

Palaeogeographic maps were constructed for the Mid Miocene interval from the knowledge gained from seismic, wireline and lithofacies analysis (Chapter 3 to Chapter 6). These maps provide an improved understanding of the development of the Moki Formation and allow a simple, visual method to compare the results of this study with previous interpretations. This chapter presents these palaeogeographic maps and discusses the spatial and temporal development of the Moki Formation and S1/Sw Sandstone fan systems.

\subsection{Inputs}

Four palaeogeographic maps have been created. Of these, three represent the deposition of the Moki Formation during the Late Altonian (c. 16.5 Ma), Clifdenian (c. 15.5 Ma), Early Lillburnian (c. 14.5 Ma) and one map represents the deposition of the S1/Sw Sandstone during the Waiauan (c. 12.5 Ma). Age and depositional environment constraints were provided by palaeontological data, lithofacies and wireline log facies from wells, and seismic facies (see Chapters 4 to 6). In addition, seismic interpretation provided information about timing and style of faulting. Observations presented in previous reports were also used to constrain some further details, particularly those beyond the scope of this project.

Stage boundaries were defined by palaeontological data and the correlated seismic horizon interpretation. As discussed in previous chapters, the stage boundaries are often poorly constrained and therefore the corresponding seismic horizons are only approximates of the boundary. Accordingly, the exact location of palaeogeographic features may vary slightly from that depicted. A best estimate has been applied here.

Palaeobathymetry was constrained by foraminiferal assemblages at each well (Table 7.1) with an additional constraint provided by the location of the shelf-slope break identified on seismic profiles. The palaeobathymetric data showed good correlation between most wells and matched interpreted seismic facies closely. However, palaeobathymetric data from Tasman- 1 is consistently deeper than is shown on the maps, as a lower-slope depth at this 
location was difficult to justify with the present constraints. The boundary between the mid- and lower-slope is not well constrained as many of the samples are simply defined to the mid- to lower-slope range. Bathymetry contours followed the general trend of the identified shelf-slope break.

\begin{tabular}{|c|c|c|c|c|}
\hline \multirow[b]{2}{*}{ Well } & \multicolumn{4}{|c|}{ Palaeobathymetry } \\
\hline & Altonian & Clifdenian & Early Lillburnian & Waiauan \\
\hline Cape Farewell-1 & \multicolumn{4}{|c|}{-unconformity- } \\
\hline Fresne-1 & Upper-slope & $\begin{array}{l}\text { Outer-shelf to upper- } \\
\text { slope }\end{array}$ & $\begin{array}{l}\text { Outer-shelf to upper- } \\
\text { slope }\end{array}$ & - not identified - \\
\hline Hochstetter-1 & Lower mid-slope & - not identified - & Lower-slope & Lower-slope \\
\hline Kea-1 & Mid-slope & Mid-slope & Lower-slope & $\begin{array}{l}\text { Varies from } \\
\text { outermost-shelf to } \\
\text { lower-slope }\end{array}$ \\
\hline Kiwa-1 & Mid-slope & Mid- to lower-slope & Mid- to lower-slope & $\begin{array}{l}\text { Lower-slope } \\
\text { shallowing to mid- } \\
\text { slope }\end{array}$ \\
\hline Kupe South-2 & Outer-shelf & Outer-shelf & Outer-shelf & \\
\hline \multicolumn{5}{|l|}{ Kupe South-3 } \\
\hline Kupe South-4 & Outer-shelf to slope & Outer-shelf to slope & Outer-shelf to slope & \\
\hline Kupe South-5 & Outer-shelf & Outer-shelf & Outer-shelf & \\
\hline Kupe-1 & Mid-shelf to slope & Mid-shelf & Mid-shelf & \\
\hline Maari-1 & \multicolumn{4}{|c|}{-no biostratigraphy data- } \\
\hline Maui South-1 & \multicolumn{4}{|c|}{-no biostratigraphy data- } \\
\hline Maui-1 & Slope & Outer-shelf to slope & Outer-shelf to slope & Outer-shelf to slope \\
\hline Maui-2 & Mid- to lower-slope & Mid- to lower-slope & Lower-slope & Lower-slope \\
\hline \multicolumn{5}{|l|}{ Maui-3 } \\
\hline Maui-4 & Mid- to lower-slope & Mid- to lower-slope & Mid- to lower-slope & Mid- to lower-slope \\
\hline Maui-5 & \multicolumn{4}{|c|}{-no biostratigraphy data- } \\
\hline Maui-7 & \multicolumn{4}{|c|}{-no biostratigraphy data- } \\
\hline $\mathrm{MB}-\mathrm{P}(8)$ & \multicolumn{4}{|c|}{-no Miocene biostratigraphy data- } \\
\hline$M B-Z(11)$ & \multicolumn{4}{|c|}{-no biostratigraphy data- } \\
\hline Moki-1 & Mid-slope & Lower-slope & Lower-slope & Lower-slope \\
\hline Moki-2A & Mid- to lower-slope & $\begin{array}{l}\text { Shallowing from } \\
\text { lower-slope to mid- } \\
\text { slope }\end{array}$ & Mid- to lower-slope & Mid-slope \\
\hline Motueka-1 & Mid-slope & $\begin{array}{l}\text { Outer-shelf to upper- } \\
\text { slope }\end{array}$ & Mid- to outer-shelf & -unconformity- \\
\hline North Tasman-1 & Upper-slope & Mid- to lower-slope & Mid- to lower-slope & shelf break \\
\hline Pukeko-1 & - not identified - & Deep-lower slope & - not identified - & Lower-slope \\
\hline Rahi-1 & \multicolumn{4}{|c|}{-no biostratigraphy data- } \\
\hline Surville-1 & Non-marine - paralic & -unconformity- & -unconformity- & -unconformity- \\
\hline
\end{tabular}




\begin{tabular}{|l|l|l|l|l|}
\hline \multirow{2}{*}{ Well } & \multicolumn{1}{c|}{ Palaeobathymetry } \\
\cline { 2 - 5 } & \multicolumn{1}{|c|}{ Altonian } & \multicolumn{1}{c|}{ Clifdenian } & Early Lillburnian & \multicolumn{1}{c|}{ Waiauan } \\
\hline & to marginal marine & & & \\
\hline Tahi-1 & -unconformity- & -unconformity- & -unconformity- & -unconformity- \\
\hline Tasman-1 & Lower-slope & ?lower-slope & ?lower-slope & -not identified- \\
\hline Te Whatu-2 & Mid- to lower-slope & Lower-slope & Lower-slope & Lower-slope \\
\hline Toru-1 & Upper-slope & Uppermost-slope & $\begin{array}{l}\text { Uppermost-slope to } \\
\text { deep outer-shelf }\end{array}$ & \\
\hline Tui-1 & $\begin{array}{l}\text { Lower-slope to mid } \\
\text { lower-slope }\end{array}$ & Deeper lower-slope & Lower-slope & Lower-slope \\
\hline
\end{tabular}

Table 7.1: Summary of palaeobathymetry information for each well as determined from foraminifera in cuttings and sidewall core samples. Shaded boxes indicate instances where palaeontological data does not agree with the bathymetry inferred in the palaeogeographic maps. Data are from open-file biostratigraphy reports (Appendix B).

Depositional environments were defined by seismic facies (see Chapter 4) and were corroborated with well data. These seismic facies define the extent of the shelf, slope, Moki Formation mid-fan system, fan channels of both the Moki Formation and S1/Sw Sandstone, outer-fan and fan extent. In addition, feeder channels for the Sl/Sw Sandstone have been identified (see also Bushe et al., 2008). Other channels presented on the maps are conceptual. Unfortunately, seismic quality was not sufficient to map individual fan lobes, so those depicted are conceptual. No distinct upper fan facies of the Moki Formation was indicated by either well data or seismic facies. Altonian-aged coal measures and fluvial-deltaic sandstones in Surville-1 were the only terrestrial or marginalmarine sediments of Miocene age intersected in the study area.

Active faulting and folding has a significant impact on the character and geometry of sedimentary infill. By the Early to Mid Miocene, areas to the east of the study area were uplifted by the Taranaki and Flaxmore faults (King and Thrasher, 1996; Vonk and Kamp, 2008). Well data from the Kupe field wells, Tahi-1, Toru-1 and the onshore Kapuni field wells show that the Manaia Anticline was uplifted by the Mid Miocene, with the Kupe field wells at shelfal depths (King and Thrasher, 1996; this study). The Surville Fault is inferred to be active at this time, due to the presence of terrestrial sediments in Altonian times overlying marine sediments in Surville-1 (King and Thrasher, 1996). Areas of the northern West Coast of the South Island (e.g. Nathan et al., 1986; King, 2000b) and Marlborough Sounds (Nicol and Campbell, 1990) were uplifted, and this is where the sediment of the Moki Formation is thought to be sourced. Furthermore, the Cape Egmont Fault is interpreted to be reactivated as a reverse fault down-thrown to the northwest during 
the Lillburnian as seismic interpretation shows syn-sedimentary growth. Structural restorations (Baur et al., 2008b) suggest that the amount of offset is minor (about seismic resolution) but even a small offset would affect sediment distribution.

Previous studies (e.g. de Bock et al., 1991; Higgs, 2004) have indicated a plutonic and subordinate metamorphic source for the Moki Formation sediment, suggesting the Separation Point Massif in North West Nelson. This is further supported by tectonic reconstructions that imply the reverse faulting and basin inversion in Westland was well established by the early Altonian, permitting the exposure of sediment (King, 2000b). This interpretation of a southern provenance for the Moki Formation is supported in this study.

\subsection{Results and discussion}

In the southern Taranaki Basin, Miocene sediments collectively form a thick wedge that thins toward the northwest. Within this mudstone-dominated package are a number of turbidite complexes, of which the thickest, most widespread and most sand-rich is the Moki Formation. A chronostratigraphic panel (Figure 7.2) from south to north, through 11 key wells in the study area was created for the Mid Miocene and tied to the palaeogeographic maps presented in this study. This chronostratigraphic panel shows that throughout the Mid Miocene, most of the basin was at mid-lower slope, deepening to the north. During the Clifdenian, water depths increased, which may be related to the formation of widespread Moki Formation fans. During the Lillburnian and Waiauan stages, an overall progradation of marine sediments to the north is evident. A Late Miocene unconformity has eroded some of the sediment, particularly on the anticlines in the south of the study area. Details of the palaeogeography through the Mid Miocene is discussed in detail in this section. 


\begin{tabular}{|c|c|c|c|}
\hline LEGE & $\begin{array}{l}\text { ND } \\
\text { Depositional Environment }\end{array}$ & $\begin{array}{l}\text { Estimated } \\
\text { Water Depth }\end{array}$ & \\
\hline 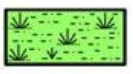 & terrestrial/paralic sediments & $+m$ & Non-deposition / erosion \\
\hline & shoreface - inner shelf & $0-50 \mathrm{~m}$ & proximal submarine fan \\
\hline & mid shelf & $50-100 \mathrm{~m}$ & distal submarine fan \\
\hline--- & $\begin{array}{l}\text { outer shelf } \\
\text { shelf-slope break }\end{array}$ & $100-200 \mathrm{~m}$ & $\begin{array}{l}\text { poorly constrained } \\
\text { submarine channel system }\end{array}$ \\
\hline & uppermost slope & $200-400 \mathrm{~m}$ & $\begin{array}{l}\text { seismically-mapped } \\
\text { submarine channel system }\end{array}$ \\
\hline & upper slope & $400-600 \mathrm{~m}$ & well \\
\hline & mid slope & $600-1000 \mathrm{~m}$ & seismic constraint \\
\hline & lower slope & $1000-1500 \mathrm{~m}$ & active fault \\
\hline & deep lower slope & $1500-2000 \mathrm{~m}$ & drainage direction \\
\hline
\end{tabular}

Figure 7.1: Legend for the chronostratigraphic panel (Figure 7.2) and palaeogeographic maps (Figure 7.3 to Figure 7.6).

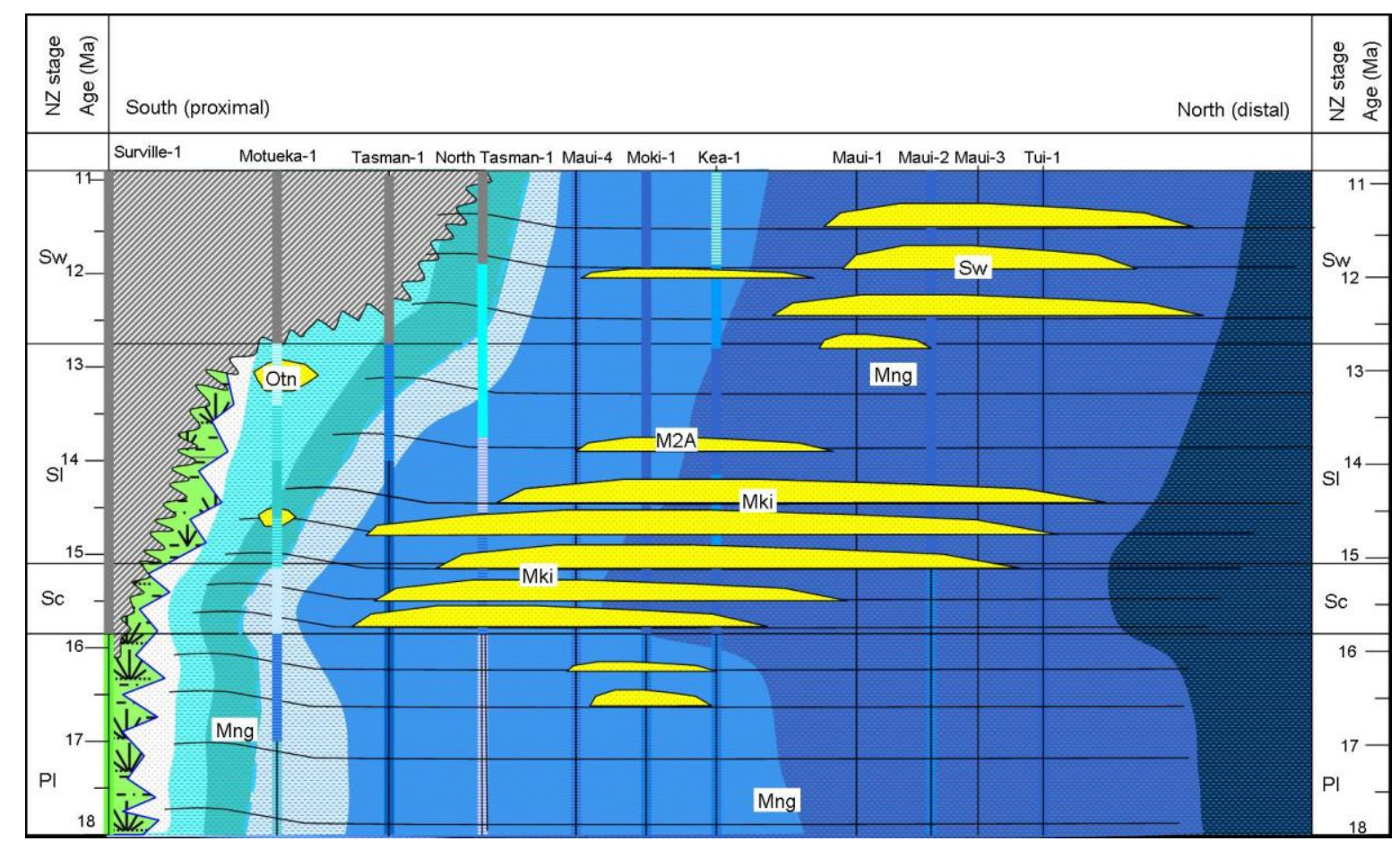

Figure 7.2: Chronostratigraphic panel from south (proximal) to north (distal) through key wells in the study area. Abbreviations are as follows: Otn = Otunui Formation Equivalent, Mki = Moki Formation, Mng = Manganui Formation, M2A = M2A Sandstone, $\mathrm{Sw}=\mathrm{S} 1 / \mathrm{Sw}$ Sandstone. Symbols and colours are as per legend Figure 7.1. Stage boundaries from Cooper (2004). Foraminifera-determined palaeobathymetry is shown on well sticks in the same colour scheme. Bathymetry deepens to the north and generally shallows with time. A bathymetric deepening during the Clifdenian is recorded in several wells followed by a widespread regression as a response to large sediment influx. Fan bodies depicted are conceptual. 
During the Late Altonian (Figure 7.3) most of the basin was submerged to bathyal depths with water depths increasing to the northwest. The shelf was broadly arcuate, orientated east-west in the southern part of the basin and turned toward to the northeast in the east of the study area; this change in orientation was probably caused by the uplift along the eastern margin of the basin. Sediment to the basin-floor was predominantly derived from the south where the presence of paralic / terrestrial sediments is supported by the fluvialdeltaic sediments intercepted in Surville-1. Sediment influxes from the south formed relatively small basin-floor fans located over, and to the east of, the Moki-Maari area. Wireline log correlations suggest these sands were geographically isolated to a few central wells. These fans represent the first Miocene-aged sands deposited on the bathyal sea floor.

During the Clifdenian, water depths increased so that there was a southward migration of bathymetric contours and of sand depocentres (Figure 7.4). This deepening appears to have occurred concurrently as the onset of major sand influx to the basin floor. These sand influxes established and built up the sub-marine fans of the Moki Formation, centred between Tasman-1 to Moki-1 wells and extended as far north as the Maui Field. Sands were not distributed onto the Western Stable Platform.

The main phase of deposition on the Moki Formation fans was during the Early Lillburnian (Figure 7.5). Sediment was supplied to the fans via a combination of mass wasting and channelisation of the shelf and upper / uppermost slope and was deposited as massive, well-sorted sands as sheet-like bodies on the basin-floor. These sub-marine fans were geographically extensive, with mid fan facies identified north of the Maui Field, and some sand deposited as far as the Kiwa-1 well on the Western Stable Platform. Highly sinuous meandering channels were incised onto the fan surface, which acted as pathways for small density currents. The shelf and slope built out into the basin to the northwest, which probably constrained the eastern limit of the fan system, producing the observed abrupt change in seismic facies. In contrast, the western and northern extents of the fan system were unconstrained.

The top of the Moki Formation is distinct through the central fan system in both its seismic and wireline log character. On wireline logs, there is a marked change from the repeated blocky sandstone packages of the Moki Formation to uniform mudstone of the overlying Manganui Formation, which mirrors a change in seismic character changes from high 
amplitude, coherent reflectors to the low amplitude reflectors. This implies an abrupt cessation in sand influx to the basin floor. However, there are a few indications of an abandonment phase of the fan system. Firstly, there are a few cases within the central fan system where discrete sandstone bodies exist 50 to $100 \mathrm{~m}$ above the high net:gross sandstone package of the Moki Formation. These include the M2A sandstone in the MokiMaari area, which is separated from the Moki Formation by $~ 50 \mathrm{~m}$ of mudstone, and in the two discrete sandstone packages are above the Moki Formation in the Kea-1 well. This indicates occasional, localised sand influx after the main period of the Moki Formation. Secondly, the highly sinuous channels seen within the Maui Field are only seen at the very top of the Moki Formation and are not imaged anywhere else in the basin, due to the poorer seismic quality in these areas. These channels are infilled with low amplitude reflectors, interpreted to be mudstone, which was possibly deposited in the channels as background suspension settlement after cessation of the high-density flows that deposited the sandstones of the Moki Formation. These channels therefore may have been formed during an abandonment phase of that fan lobe. 


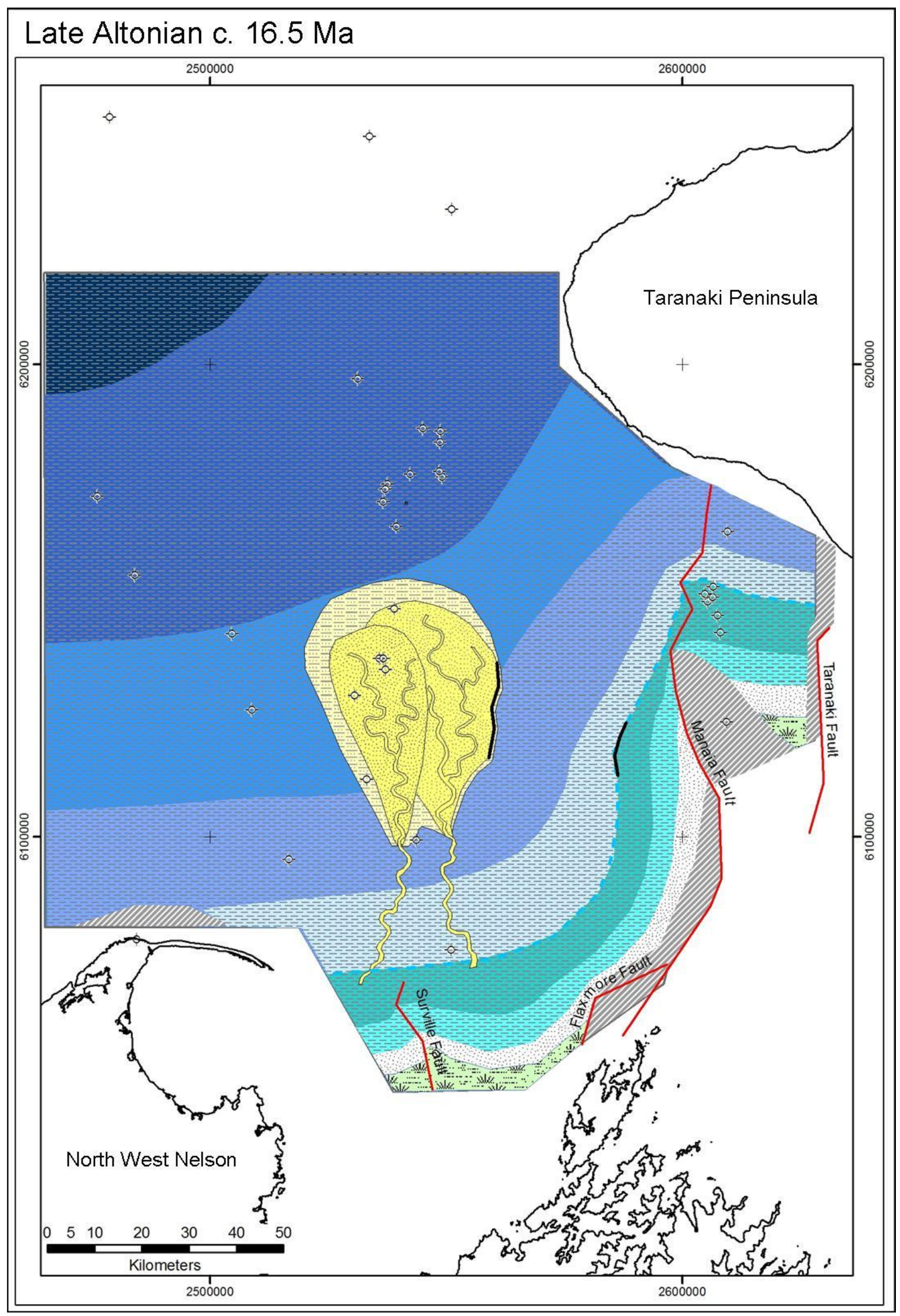

Figure 7.3: Late Altonian palaeogeographic interpretation of the study area. Coordinates are in New Zealand Map Grid. Colours and symbols are as per legend in Figure 7.1. 


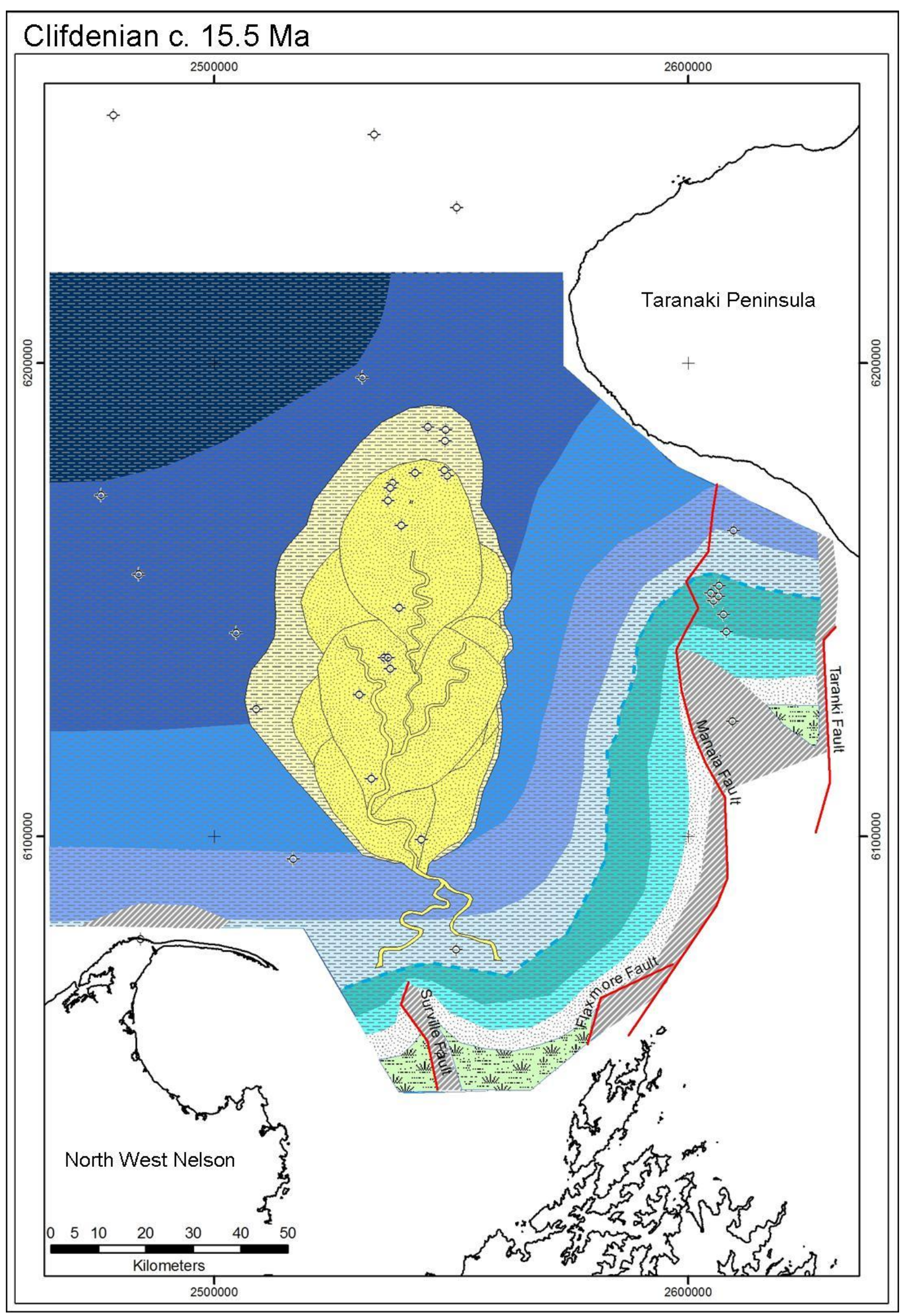

Figure 7.4: Clifdenian palaeogeographic interpretation of the study area. Colours and symbols are as per legend in Figure 7.1. 


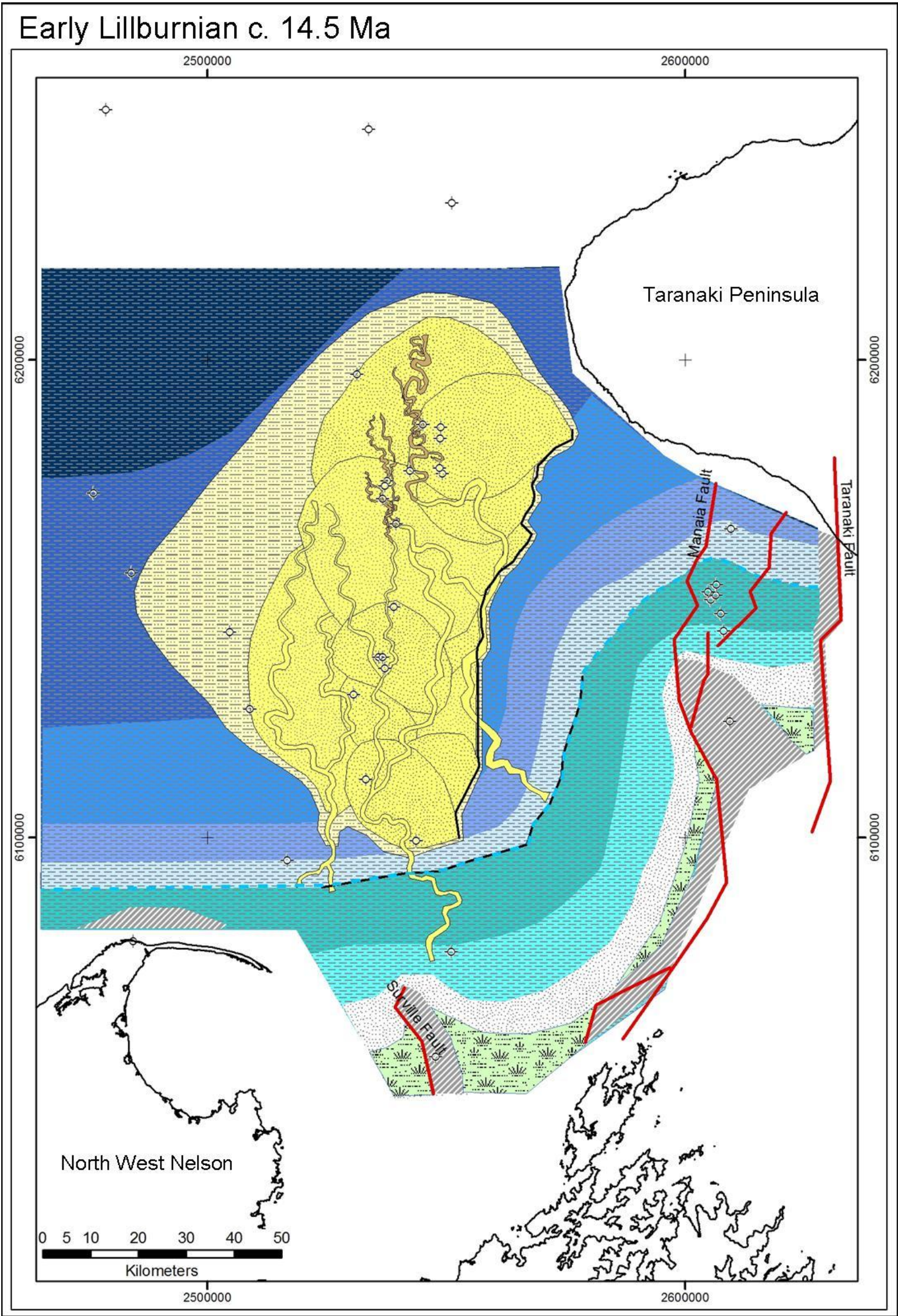

Figure 7.5: Early Lillburnian palaeogeographic interpretation of the study area. Colours and symbols are as per legend in Figure 7.1. 
The deposition of the Moki Formation was followed by a time of general quiescence with sediment supplied to the basin floor dominated by mud. Rare sand influxes occurred on the Western Stable Platform, which did not spread far as indicated by amplitude variations of the corresponding seismic reflectors. No or very little sand was deposited through the central area. A map for the time interval between the cessation of Moki Formation deposition and the onset of S1/Sw Sandstone deposition (i.e. Late Lillburnian) was not created in this study.

By the Waiauan stage (Figure 7.6) the shelf widened as the slope prograded northwards. The shelf-slope break appears to have changed orientation to an overall northeastsouthwest orientation during the Waiauan, which may have been caused by faster rates of outbuilding of the shelf to the south and / or a reduction in the rate of uplift of the Manaia Anticline. Deep channels incised the shelf, which permitted sediment to be supplied to the basin floor. These feeder channels are located farther to the north and east of the inferred feeder channels of the Moki Formation. The deep shelfal channels were subsequently infilled with homogeneous sediment that accreted laterally within the channel (Bushe et al., 2008).

The sub-marine fans of the S1/Sw Sandstone were deposited at mid- to lower-slope depths in the northwestern quadrant of the study area and were intersected by Tui-1 and the Maui wells. The fans were thickest and most sand rich near the Tui-1 well. In addition, a few sheet sands were deposited in the central part of the study area. Some authors (e.g. Engbers, 2002) have suggested that these sands were deposited at the base of slope; however, there is no evidence in the palaeontological data that supports this statement. The Maui-4 and Moki structures were beginning to be uplifted during the Late Lillburnian and sediment was channelised in the intermediate trough (Dauzacker et al., 1996). The fans were incised by northwest-southeast meandering channels, which continue beyond the fan extent, merge and trend to the north out of the study area. These channels would have followed an area of greatest depression; ultimately they would probably have led out to the abyssal New Caledonia Basin. This implies a far-greater degree of sediment bypassing occurred than the Moki Formation fan system. 


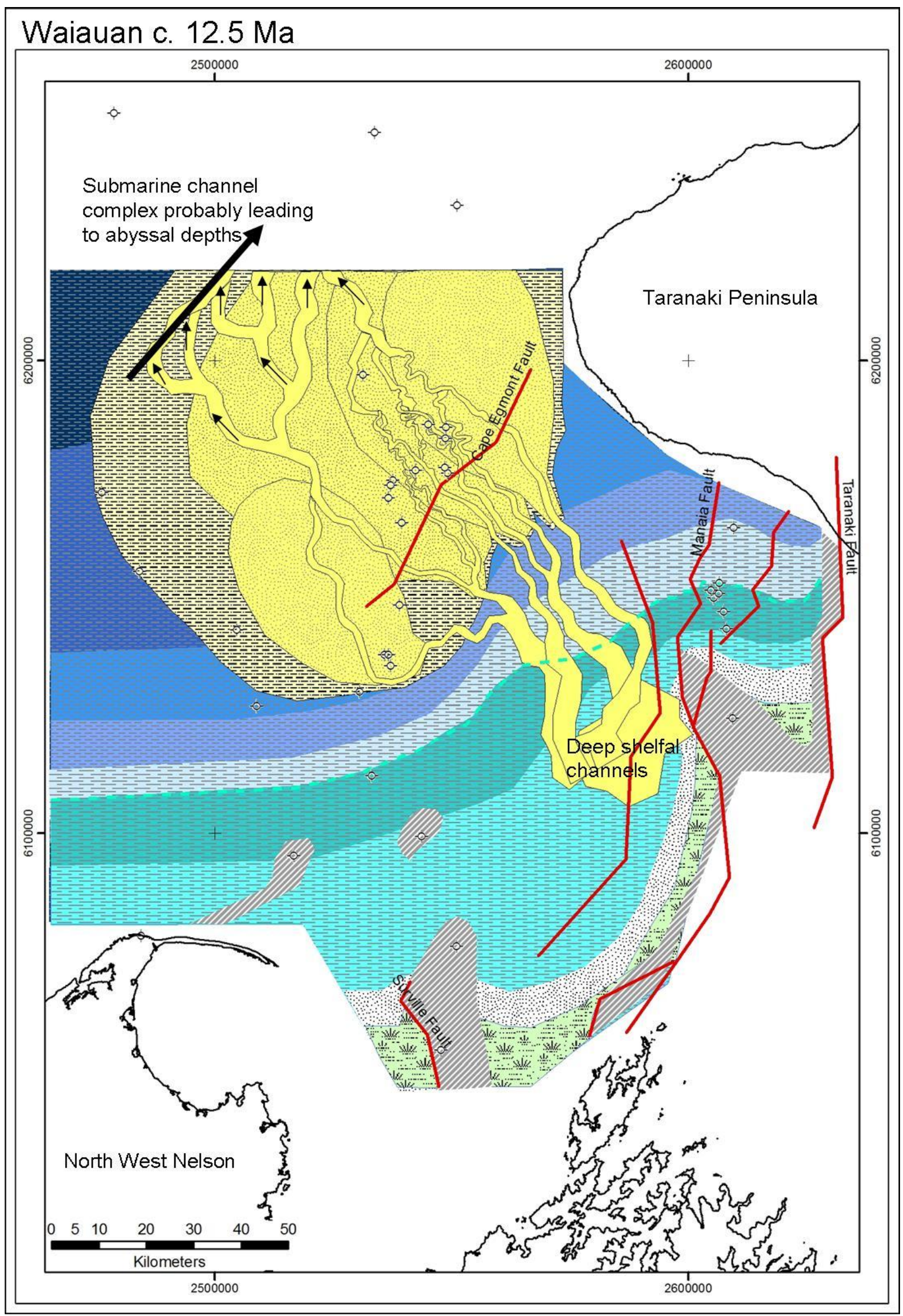

Figure 7.6: Latest Lillburnian / Waiauan palaeogeographic interpretation of the study area. Colours and symbols are as per legend in Figure 7.1. 
The Moki Formation and the S1/Sw Sandstone are both sandstone-dominated units deposited in a bathyal environment from a series of high-density flows. However, the Moki Formation is thicker, geographically more extensive, more sand-rich, less channelised and its deposition was more prolonged than the $\mathrm{Sl} / \mathrm{Sw}$ Sandstone. These fan systems may have been created under differing sedimentary processes with a far greater degree of sediment bypassing during the Waiauan.

Previous palaeogeographic maps of the Moki Formation have provided a good framework for understanding the depositional system, which have now been improved with the identification of further constraints from this multidiscipline approach. All palaeogeographic maps produced for the Mid Miocene time interval (see de Bock, 1994; King and Thrasher, 1996; this study) agree with a north-trending fan system with mid-fans or central-fans located between North Tasman-1 to the Maui Field with its distal terminations near the Kiwa-1 well on the Western Stable Platform. The interpretations illustrate a shelf-slope break that was orientated east-west in the south of the basin, which curved toward the north along the Manaia Fault. Most sediment is inferred to be derived from the south with little sediment inferred to come from the Manaia Fault region. However, there are some key differences in the various interpretations of fan geometries of the Moki Formation and their subsequent implications, discussed below.

The palaeogeography map of De Bock (1994) depicts an elongate, delta-fed fan system which appears to be closely linked with the mud-rich fine-grained model of Stow et al., (1985). However, the Moki Formation is distinctly a sand-rich turbidite complex with greater complexity seen in seismic profiles than is implied in this de Bock's (1994) map. Accordingly, this idea of an elongate, delta-fed system was not supported here.

In contrast, King and Thrasher (1996) presented an interpretation of a much broader system with balloon-shaped fans extending from the Western Stable Platform to the eastern margin. The slope depicted by King and Thrasher (1996) runs east-west along the southern margin of the basin and, rather than curving to a south-north orientation, terminates at the Manaia Fault. In this study, the location and orientation of the slope has been guided by the delineation of the shelf-slope break on seismic profiles farther north than that depicted by King and Thrasher (1996). Observation of seismic facies has eliminated the possibility of fan sandstones in the east of the study area and no evidence for channelisation is seen in this region (Baur et al. 2008a). The orientation of this slope may have been a controlling factor on the eastern extent of the Moki Formation fans as 
density flows preferentially followed areas of greatest depression. On the Western Stable Platform, the high amplitude, coherent reflectors pass gradually into a generally lower, but more variable amplitude, thinner, sub-parallel seismic facies implying that prolonged midfan facies did not exist here, but the distal equivalents of the mid-fan in the central area extended over a long distance.

No palaeogeographic maps to date have been produced for the Waiauan time-interval or for the Sl/Sw Sandstone. This study has clarified that the S1/Sw Sandstone was deposited is a distinct sub-marine fan body from the Moki Formation and was deposited from Latest Lillburnian to Waiauan times.

\subsection{Summary}

This study has presented improved palaeogeographic maps for the Mid Miocene by locating the coeval shelf-slope break, slope, central fan areas, outer fan areas and the lateral extent of Moki Formation and its equivalents by identification and mapping of key seismic facies with corroboration from well data. Following this, the first sands of the Miocene were deposited over a small area during the Late Altonian. A deepening during the Clifdenian led to a backstepping of the sand depocentre with fans becoming well developed and widespread. By the Early Lillburnian, the Moki Formation fans were extensive with complex channelisation and fan lobe switching. Sand influx abruptly ceased from Mid to Late Miocene and sediment deposited was dominated by mud. Highdensity currents to the basin floor occurred again during the Waiauan with a significant amount of channelisation and sediment bypassing.

Whilst the palaeogeography of the Moki Formation is better constrained through the location of these key palaeogeographic features, there is a component of uncertainty inherent in these maps. Some of this uncertainty may be reduced by further work, whilst some cannot (for example, the eroded rock off the drilled anticlines cannot be replaced). Further work for the improvement of the understanding of the Moki Formation, include detailed studies of aspects such as transportation of sediment from shelf to slope and resolving fan bodies. However, this may require an improvement in the quality of the present seismic database in some areas, and improved resolution of foraminiferal biostratigraphy. 


\subsection{Conclusions}

\subsection{Project achievements}

This project investigated the regional distribution, timing and style of the Moki Formation turbidite complex, southern Taranaki Basin, New Zealand. This was achieved through the analysis of seismic data, wireline log data and core facies of the Mid Miocene stratigraphic interval. In particular, this study has:

- $\quad$ mapped the Mid Miocene interval on 2D seismic data within the southern offshore region of Taranaki Basin;

- $\quad$ defined the limits of Moki Formation and S1/Sw Sandstone fan development;

- $\quad$ identified and described the nature of the coeval shelf-slope break in the southeast of the study area;

- $\quad$ found evidence for fan lobe switching in the Moki-Maari area and the Maui Field through amplitude variations;

- $\quad$ mapped spectacular meandering channels within the Maui Field at both the Moki Formation and S1/Sw Sandstone levels;

- $\quad$ identified and mapped a channel system within the S1/Sw Sandstone to the northwest of the Maui Field which leads to the north-northeast;

- $\quad$ supported evidence for progradation of the Moki fan system to the northwest, and

- $\quad$ presented revised palaeogeographic maps for the Late Altonian, Clifdenian, Early Lillburnian and Waiauan stages.

Consequently, the understanding of the temporal and spatial development of the Moki Formation and the S1/Sw Sandstone turbidite complexes has been improved and better constrained through this multi-faceted approach.

\subsection{Geological history}

The insights gained from this study have produced a more detailed understanding of the Mid Miocene geological history. Deposition of Miocene sands within the study area began during the Late Altonian as a result of increasing tectonic uplift exposing sediment source rocks in the hinterland to the south and east. These sands were deposited as small, 
localised fan bodies and were intercepted by the Maui-4 and Moki-1 wells. A bathymetric deepening occurred during the Clifdenian, which may have caused a backstepping of the fans to the south and lead to the onset of voluminous sand influxes. Sands continued to enter the basin via a combination of mass-wasting and channelisation on the shelf to upper slope, and consequently the Moki Formation fans became well developed and spread farther northward. By the early Lillburnian, mid-fan facies were located as far north as the Maui Field with south-north trending highly sinuous channels present at the very top of the formation. Sand influx appears to have ceased rather abruptly with only a few sands deposited after the Moki Formation. During the Mid to Late Lillburnian, sediment deposited was almost entirely mud through the centre of the study area, whereas minor sand influx continued to occur on the Western Stable Platform.

During the Latest Lillburnian to Waiauan, large, deep channels incised the shelf, acting as a pathway for sediment into bathyal waters and thus supplying sediment to the submarine fans of the Sl/Sw Sandstone to the northwest of the Maui Field. At this time, the Cape Egmont Fault was reactivated as a reverse fault with a small offset down-thrown to the northwest. Several meandering channels have been imaged to come from the fault. These meandering channels allowed for transportation of excess sediment beyond the sub-marine fans to deeper water, possibly into the New Caledonia Basin.

\subsection{Implications for hydrocarbon prospectivity}

The Moki Formation consists of thick, amalgamated, massive, well-sorted sandstone packages with subordinate mudstone and secondary interbedded or laminated sandstone facies. Amalgamated, tabular sandstone packages may be up to $100 \mathrm{~m}$ thick, and the entire sand-dominated formation is commonly more than $300 \mathrm{~m}$ thick with a high net:gross sandstone ratio. This large volume of sand reflects the prolonged tectonic uplift of the hinterland that was on going during the time of deposition and is unsurpassed by any other turbidite complex in the basin. The development of the Maari Field has proven that the formation can contain and produce economic amounts of hydrocarbons.

The identification of hydrocarbon exploration prospects was beyond the scope of this project; however, the greater knowledge of the system has provided some insights into the sandstone development of the Moki Formation in the southern Taranaki Basin. In this study, the extent of sandstone development has been defined by seismic facies with fan sandstones represented by coherent, high amplitude reflectors. Within this seismic facies, 
a number of stratigraphic trapping opportunities may be possible. For example, along the eastern margin of the Moki Formation fan system, the sudden change in reflector amplitude and continuity suggesting abrupt fan sandstone development from slope mudstone may provide a stratigraphic trap opportunity. Sandstones are predicted to be thick and abundant through the central region from Maari field as far south as North Tasman-1 may provide stacked reservoir, with stratigraphic traps provided by fanswitching geometries. Moreover, the S1/Sw Sandstone has largely been unexplored for its hydrocarbon potential. Sandstones are best developed to the northwest of the Maui Field. The large channels through the $\mathrm{Sl} / \mathrm{Sw}$ sandstone may also prove economically significant with potential sandstone infill.

\subsection{Future work}

Some details of these Mid Miocene turbidite complexes remain unresolved; this uncertainty may be reduced by additional work. For the Moki Formation aspects for further study include trying to resolve feeder channels or mass-wasting signatures in the southern part of the area, to better determine the source of the Moki Formation and its emplacement mechanisms. Locating and imaging in plan-view the fan channels south of the Maui Field would help to resolve some of the mechanisms of sand distribution on the fan surface and how this changed spatially and temporally. In addition, mapping individual fan lobes, perhaps by using amplitude variations, through the centre of the study area would better constrain the style of deposition and the geometry of the fan system.

Within the S1/Sw Sandstone, resolving the spatial extent of the fan system better and mapping individual reflectors may upgrade the potential of this sandstone as a reservoir. Tracing the complex channel system out of this study area and identifying any feature that may constrain the channels pathway could improve the understanding of the basin slope at this time.

The ability to undertake some of this work may depend on higher quality seismic reflection profiles and higher resolution biostratigraphy being acquired and becoming available. The work would also be improved when more wells are drilled in the area with detail over the Miocene section to "ground-truth" seismic interpretation. Some of this work may have already been undertaken by oil companies, but the results of which are not currently in the public domain and therefore cannot be utilised. 


\section{References}

Adams, C.J.D. 1979: Age and origin of the Southern Alps. In: R.I. Walcott, M.M. Cresswell, ed., The origin of the Southern Alps. The Royal Society of New Zealand Bulletin 18: 73-78.

Adams, R.D, Ware, D.E. 1977: Sub-crustal earthquakes beneath New Zealand; locations determined with a laterally inhomogeneous velocity model. New Zealand Journal of Geology and Geophysics 20: 59-83.

Anderton, R. 1995: Sequences, cycles and other nonsense: are submarine fan models any use in reservoir geology? Geological Society of London, Special Publications 94: 5-11.

Armstrong, P.A., Allis, R.G., Funnell, R.H., Chapman, D.S. 1998: Late Neogene exhumation patterns in Taranaki Basin, New Zealand: Evidence from offset porositydepth trends. Journal of Geophysical Research 103: 30,269 - 30,282.

Arnot, M., Leitner, B., Baur, J., Bland, K., Bushe, H., Funnell, R., Ilg, B., Jones, C., King, P., Milner, M., Massey, M., Morgans, H., Roncaglia, L., Zhu, H. 2008: A new generation of digital structure maps for Taranaki Basin: progress towards a "4D Taranaki Basin". 2008 New Zealand Petroleum Conference Proceedings. Ministry of Economic Development.

Baur, J., Arnot, M., Bushe, H., Ilg, B., Leitner, B., King, P., Milner, M., Roncaglia, L., Stern, T., Zhu, H. 2008a: Sedimentary facies development in offshore southeastern Taranaki Basin from attribute analysis of 2D and 3D seismic reflection data. Abstracts of the Geological Society of New Zealand, New Zealand Geophysical Society and New Zealand Geochemical and Mineralogical Society Joint Annual Meeting 23-26 November 2008 .

Baur, J., Ilg, B., Zhu, H., Milner, M. King, P., Bushe, H., Jones, C., Leitner, B., Massey, M., Morgans, H., Roncaglia, L. 2008b: Structural restoration of a 540 km-long regional line across central Taranaki Basin. 2008 New Zealand Petroleum Conference Proceedings. Ministry of Economic Development. 
Beggs, J.M. 1990: Seismic stratigraphy of the Plio-Pleistocene Giant Foresets, Western Platform, Taranaki Basin. Proceedings of the 1989 New Zealand Oil Exploration Conference: 201-207.

Boggs, S.J. 2001: Principles of sedimentology and stratigraphy. Third ed. Prentice Hall, New Jersey.

Bouma, A.H. 1962: Sedimentology of some flysch deposits: a graphical approach to facies interpretation. Elsevier Publishing Company, Amsterdam.

Bouma, A.H. 2000: Fine-grained, mud-rich turbidite systems: model and comparison with coarse-grained, sand-rich systems. In: A.H. Bouma, C.G. Stone, ed., Fine-grained turbidite systems, AAPG Memoir 72 / SEPM Special Publication 68: 9-20.

Bouma, A.H. 2004: Key controls on the characteristics of turbidite systems. Geological Society, London, Special Publications 2004 222: 9-22.

Brand, R.P., Buchan, R.J., Mills, K.L. 1999: An assessment of the prospectivity of hydrocarbon traps in the footwall of the Taranaki Fault, PEP 38729, Onshore North Taranaki. Petroleum Report Series PR2502. Ministry of Economic Development.

Browne, G.H. 1998: Immediate report on core from Maari-1. In: Shell Todd Oil Services (1999): Maari-1 and -1A well completion report PPL 38413. Petroleum Report Series PR1572.

Browne, G.H. 1999: A sedimentological description of the Moki Formation core, Maui South-1 well, Taranaki. In: Shell Todd Oil Services (1999), Maui South-1 Well Completion Report PML 301012. Petroleum Report Series PR2254. Ministry of Economic Development.

Bushe, H., Baur, J., Arnot, M., Ilg, B., Jones, C., King, P., Leitner, B., Massey, M., Milner, M., Morgans, H.E., Roncaglia, L., Zhu, H. 2008: Mapping and visualisation of MidMiocene channel systems in the Kupe region. 2008 New Zealand Petroleum Conference Proceedings. 
Bussell, M.R. 1994: Seismic interpretation of the Moki Formation on the Maui 3D survey, Taranaki Basin. 1994 New Zealand Petroleum Conference Proceedings. Ministry of Economic Development, 240-255.

Cant, D.J. 1984: Subsurface facies analysis. In: Walker, R.J. ed. Facies models. Geological Association of Canada, 297 - 310.

Challis, G.A. 1990: Petrography of Miocene sandstones from Midhurst-1, Kapuni-1 and Kapuni-9. Petroleum Report Series PR1532. Ministry of Economic Development.

Cooper, R.A. 2004: New Zealand Geological Timescale 2004/2 wallchart. Institute of Geological and Nuclear Sciences information series 64.

Core Laboratories. 1993: An advanced rock property study of selected samples from the Mt Messenger and Moki Formations of wells Kaimiro-2 and -3 New Zealand. Petroleum Report Series PR1877. Ministry of Economic Development.

Crown Minerals. 2008: www.crownminerals.govt.nz/petroleum

Dauzacker, M.V., Yang, J.S., Pomilio, G.A., Till, V.S. 1996: A new exploratory approach to the Moki-Manaia oil discoveries. 1996 New Zealand Petroleum Conference Proceedings. Pp 86-104.

Davies, K. 1997: Reservoir quality of the Maanga, Mt Messenger and Moki sandstones in the Taranaki Basin and the implications for the Oakura prospect PEP 38712. Petroleum Report Series PR2311. Ministry of Economic Development

De Bock, J.F. 1994: Moki Formation, a Miocene reservoir sequence, its facies distribution and source in offshore, southern Taranaki Basin. New Zealand Petroleum Conference Proceedings. Pp 155-167.

De Bock, J.F., Perry, S., Webby, D., Goodin, B. 1991: Appraisal of the Maui-4 and Moki1 oil discoveries PML 38144 PML 38145. Petroleum Report Series PR1800. Ministry of Economic Development. 
DeMets, C., Gordon, R.G., Argus, D.F., Stein, S. 1994: Effect of recent revisions to the geomagnetic reversal time scale on estimates of current plate motions. Geophysical Research Letters 21: 2191-2194.

Engbers, P. 2002: Evaluation of Moki sands prospectivity in Maui PML. 2002 New Zealand Petroleum Conference Proceedings. Ministry of Economic Development.

Higgs, K.E. 2004: A petrographic and reservoir quality of the Moki Formation, Taranaki Basin. Institute of Geological and Nuclear Sciences file report 2004/02. Petroleum Report Series PR3005. Ministry of Economic Development.

Holt, W.E., Stern, T.A. 1994a: Platform subsidence behind an active subduction zone. Nature 368: 233-236.

Holt, W.E., Stern, T.A. 1994b: Subduction, platform subsidence, and foreland thrust loading: the late Tertiary development of Taranaki Basin, New Zealand. Tectonics 13: 1068-1092.

Hounsell, S. 2006: Update on exploration activities and Maari field development plan. 2006 New Zealand Petroleum Conference Proceedings. Ministry of Economic Development.

Kamp, P.J.J., Vonk, A.J., Bland, K.J., Griffin, A.G., Hayton, S., Hendy, A.J., McIntyre, A.P., Nelson, C.S., Naish, T. 2002: Megasequence architecture of Taranaki, Wanganui and King Country basins and Neogene progradation of two continental wedges across Western New Zealand. 2002 New Zealand Petroleum Conference Proceedings. Ministry of Ecomonic Development.

Kamp, P.J.J., Vonk, A.J., Bland, K.J, Hansen, R.J., Hendy, A.J.W., Mcintyre, A.P., Ngatai, M., Cartwright, S.J., Hayton, S. Nelson, C.S. 2004: Neogene stratigraphic architecture and tectonic evolution of Wanganui, King Country, and eastern Taranaki Basins, New Zealand. New Zealand Journal of Geology and Geophysics 47: 625-644

King, P.R. 1988: Well summary sheets, Taranaki. New Zealand. New Zealand Geological Survey reports G125 and G127. 
King, P.R. 2000a: New Zealand's changing configuration in the last 100 million years: plate tectonics, basin development and depositional setting. 2000 New Zealand Petroleum Conference Proceedings. Ministry of Economic Development.

King, P.R. 2000b: Tectonic reconstructions of New Zealand: 40 Ma to Present. New Zealand Journal of Geology and Geophysics 43: 611-638.

King, P.R., Browne, G.H. 2001: Miocene Turbidite Reservoir Systems in the Taranaki Basin, New Zealand: Established plays and analogues for deep-water exploration. PESA Eastern Australasian Basins Symposium Proceedings pp 129-139. Melbourne 25-28 November 2001.

King, P.R., Naish, T.R., Browne, G.H., Field, B.D., Edbrooke, S.W. 1999: Cretaceous to Recent sedimentary patterns in New Zealand. Institute of Geological and Nuclear Sciences Limited folio series 1. Lower Hutt, New Zealand.

King, P.R., Thrasher, G.P. 1992: Post-Eocene development of the Taranaki Basin, New Zealand: convergent overprint of a passive margin. In: Watkins, J.S., Zhiquang, F., McMillan, K.J., ed. Geology and geophysics of continental margins. American Association of Petroleum Geologists memoir 53: 93-118.

King, P.R., Thrasher, G.P. 1996: Cretaceous-Cenozoic geology and petroleum systems of the Taranaki Basin, New Zealand. Institute of Geological and Nuclear Sciences Monograph 13. 243 p.

Knox, G.J. 1982: Taranaki Basin, structural style and tectonic setting. New Zealand Journal of Geology and Geophysics 25: 125-140

Leeb, W. 2008: Maari field update. 2008 New Zealand Petroleum Conference Proceedings. Ministry of Economic Development.

Lock, R. 1985: The distribution, sedimentology and petroleum prospects of the Moki Formation, Taranaki Basin, New Zealand. Petroleum Report Series PR1150. Ministry of Economic Development. 
Lowe, D.R. 1976: Grain flow and grain flow deposits. Journal of Sedimentary Petrology 46: $188-199$.

Lowe, D.R. 1982: Sediment gravity flows: II. Depositional models with special reference to the deposits of high-density turbidity currents. Journal of Sedimentary Petrology 52: 279-297.

Martin, K.R. 1990: Petrology and reservoir quality of the Moki Formation in Kapuni-9 and a comparison of Moki sandstones from Kapuni-9, Durham-1 and Burgess-1. Petroleum Report Series PR1645. Ministry of Economic Development.

Martin, K.R. 1991: Petrology and reservoir quality of the Moki Formation in Ngatoro-2, Taranaki Basin, New Zealand. Petroleum Report Series PR1918. Ministry of Economic Development.

Martin, K.R. 1993: Petrology and reservoir quality of the Moki Formation in Cardiff-1, PPL 38707, Taranaki Basin, New Zealand. Petroleum Report Series PR1975. Ministry of Economic Development.

Martin, K.R. 1995: Petrology, diagenesis and reservoir quality of the Moki Formation in Mystone-1, PPL 38705, Taranaki Basin, New Zealand. Petroleum Report Series PR2187. Ministry of Economic Development.

Matthews, E. 1989: Reassessment of Moki Sand Play. Petroleum Report Series PR2385. Ministry of Economic Development.

Matthews, E., Mills, K. 2001: The effect of burial on the porosity and permeability of Miocene sandstones in the Taranaki Basin. Petroleum Report Series PR2623. Ministry of Economic Development.

Meckel L.D. 2003: Fourth-Order Deepwater Genetic Stratigraphy, Stratigraphic Architecture, and Reservoir Stacking Patterns: Lessons from the Upper Miocene - Lower Pliocene Greater Mars - Ursa Intraslope Basin, Mississippi Canyon, Gulf of Mexico. AAPG International Conference Barcelona, Spain September 21-24, 2003 
Middleton, G.V., Hampton, M.A. 1976: Subaqueous sediment transport and deposition by sediment gravity flows in: Stanley, D.J., Swift, D.J.P. ed. Marine sediment transport and environmental management. John Wiley \& Sons, New York. Pp: 197-218.

Mitchum, R.M. 1977: Seismic stratigraphy and global changes of sea level, part 11: glossary of terms used in seismic stratigraphy. In: Payton, C.E. ed. Seismic stratigraphy applications to hydrocarbon exploration. American Association of Petroleum Geologists Memoir 26: 205-212.

Mitchum, R.M., JR, Vail, P.R., Sangree, J.B. 1977: Seismic stratigraphy and global changes of sea level, part 6: stratigraphic interpretation of seismic reflection patterns in depositional sequences. In: Payton, C.E. ed. Seismic stratigraphy - applications to hydrocarbon exploration. American Association of Petroleum Geologists Memoir 26: 117-133.

Mutti, E. 1985: Turbidite systems and their relations to depositional sequences in: Zuffa, G.C. ed. Provenance of arenites. D. Riedel, Dordrecht. Pp 65-93.

Nathan, S., Anderson, H.J., Cook, R.A., Herzer. R.H., Hoskins, R.H., Raine, J.I., Smale, D. 1986: Cretaceous and Cenozoic sedimentary basins of the West Coast Region, South Island, New Zealand. New Zealand Geological Survey Basin Studies 1.

Nicol, A., Campbell, J.K. 1990: Late Cenozoic thrust tectonics, Picton, New Zealand. New Zealand Journal of Geology and Geophysics 33: 485-494.

Nicol, A., Stagpoole, V., Maslan, G. 2004: Structure and petroleum potential of the Taranaki fault play. 2004 New Zealand Petroleum Conference Proceedings. Ministry of Economic Development.

New Zealand Overseas Petroleum Ltd 2003: Tui-1 well completion report. Petroleum Report Series PR2784. Ministry of Economic Development.

Normark, W.R. 1970: Growth patterns of deep-sea fans. American Association of Petroleum Geologists Bulletin 54: 2170-2195. 
Normark, W.R. 1978: Fan valleys, channels and depositional lobes on modern sub-marine fans: characters for recognition of sandy turbidite environments. American Association of Petroleum Geologists Bulletin 62: 912-931.

North, F.K. 1985: Petroleum Geology. Alwin \& Unwin

Palmer, J.A., Andrews, P.B. 1993: Cretaceous-Tertiary sedimentation and implied tectonic controls on the structural evolution of Taranaki Basin. In: P.F. Balance ed. South Pacific Sedimentary Basin of the World, 2. Amsterdam, Elsevier, 309-328 p.

Pickering, K.R., Hiscott, R.N., Hein, F.J. 1989: Deep marine environments: clastic sedimentation and tectonics. London ,Unwin Hyman, 416 p.

Posamentier, H.W., Davies, R.J., Cartwright, J.A., Wood, L. 2007: Seismic geomorphology - an overview. In: Davies, R.J., Posamentier, H.W., Wood, L.J., Cartwright, J.A. ed. Seismic geomorphology: Application to hydrocarbon exploration and production. Geological Society of London special publications 277: 1-14.

Pratson, L.F., Imram, J., Parker, G., Syvitski, J.P.M., Hutton, E. 2000: Debris flows versus turbidity currents: a modelling comparison of their dynamics and deposits. In: A.H. Bouma, C.J. Stone, ed., Fine-grained turbidite systems, AAPG Memoir 72 / SEPM Special Publication 68: 57-72.

Pulford, A., Stern, T. 2004: Pliocene exhumation and landscape evolution of central North Island, New Zealand: the role of the upper mantle. Journal of Geophysical Research 109: F01016.

Reading, H.G., Richards, M.R. 1994: Turbidite systems in deep-water basin margins classified by grain size and feeder system. American Association of Petroleum Geologists Buulletin 78: 792-822.

Reilly, W.I. 1965: Gravity map of New Zealand 1: 4000 000. Bouguer and Isostatic Anomalies. Department of Science and Industrial Research. Wellington.

Rich, J.L. 1951: Three critical environments of deposition and criteria for recognition of rocks deposited in them. Geology Society of America Bulletin 62: 1-20. 
Rogers, B.A., Adams, S.A., Holstege, G.C.J., Nazzer, C.A., Viets, T.P., Young, I.M. 2000: Maari-1/-1A - results and implications for development. 2000 New Zealand Petroleum Conference Proceedings. Ministry of Economic Development. Wellington.

Scott, G.H. 1991: Biostratigraphy of Motueka offshore well, Southern Taranaki Basin. DSIR Geology and Geophysics Contract Report 1990/34.

Shanmugam, G., Moiola, R.J. 1982: Eustatic control of turbidites and winnowed turbidites. Geology 10: 231-235.

Shanmugam, G. 2000: 50 years of the turbidite paradigm (1950s-1990s) deep water processes and facies models - a critical perspective. Marine and Petroleum Geology 17: 285-342

Shell BP and Todd Oil Services. 1970: Maui-4 well resume. Petroleum Report Series PR543. Ministry of Economic Development.

Shell BP and Todd Oil Services. 1982: Well resume Kiwa-1 PPL 38055. Petroleum Report Series PR880. Ministry of Economic Development.

Shell Todd Oil Services. 1993: MB-Z(11) well completion report, Maui B Field, PML 381012. Petroleum Report Series PR1911. Ministry of Economic Development.

Shell Todd Oil Services. 1999: Maari-1 and -1A well completion report, PPL 38413. Petroleum Report Series PR1572. Ministry of Economic Development.

Sherburn, S. White, R.S. 2006: Tectonics of the Taranaki region, New Zealand: earthquake focal mechanisms and stress axes. Journal of Geology and Geophysics 49: 269 $-279$.

Smale, D., Mauk, J.L., Palmer, J., Soong, R., Blattner, P. (1999): Variations in sandstone diagenesis with depth, time and space, onshore Taranaki wells, New Zealand. New Zealand Journal of Geology and Geophysics 42: 137-154

Stern, T.A. 1990: Deep seismic data offer new view of basin. Oil and Gas Journal September 17: 60-67. 
Stern, T.A., Davey, F.J. 1990: Deep seismic expression of a foreland basin: Taranaki Basin, New Zealand. Geology 18: 972-982.

Stern, T.A., Stratford, W.R., Salmon, M.L. 2006: Subduction evolution and mantle dynamics at a continental margin: central North Island, New Zealand. Reviews of Geophysics 44: RG4002

Stow, D.A.V., Howell, D.G., Nelson, C.H: 1985: Sedimentary, tectonic, and sea-level controls. In A.H. Bouma, W.R. Normark, and N.E. Barnes, ed., Submarine fans and related turbidite systems: New York, Springer-Verlag, p. 15-22.

Tricentrol Exploration Overseas Ltd. 1984: Well Completion Report Moki-1. Petroleum Report Series PR987. Ministry of Economic Development.

Tricentrol Exploration Overseas Ltd. 1985: Well Completion Report Moki-2 and Moki2A. Petroleum Report Series PR1100. Ministry of Economic Development.

Uruski, C.I. 2006: Sedimentary systems of northwest New Zealand. 2006 New Zealand Petroleum Conference Proceedings. Ministry of Economic Development.

Vail, P.R., Mitchum, R.M. 1977: Seismic stratigraphy and global changes of sea level, Part 1: overview. In: Payton, C.E. ed. Seismic stratigraphy - applications to hydrocarbon exploration. American Association of Petroleum Geologists Memoir 26: 51-52.

Vonk, A.J., Kamp, P.J.J. 2008: The late Miocene Southern and Central Taranaki Inversion Phase (SCTIP) and related sequence stratigraphy and palaeogeography. New Zealand Petroleum Conference Proceedings. Ministry of Economic Development.

Walcott, R.I. 1978: Present tectonics and late Cenozoic evolution of New Zealand. Geophysical Journal of Royal Astronomical Society 52: 137-164.

Walker, R.G. 1978: Deep-water sandstone facies and ancient sub-marine fans: models for exploration for stratigraphic traps. American Association of Petroleum Geologists Bulletin 62: 932-966. 
Walker, R.G. 1992a: Turbidites and submarine fans. In Walker, R.J. and James, N.J. ed. Facies models: response to sea level change. Geological Association of Canada, 239-263

Walker, R.G. 1992b: Facies, facies models and modern stratigraphic concepts. In Walker, R.J., James, N.J. ed. Facies models: response to sea level change. Geological Association of Canada, 1-14.

Wood, R.A., Stagpoole, V.M. 2007: Validation of tectonic reconstructions by crustal volume balance: New Zealand through the Cenozoic. GSA Bulletin 119: 933-943

Yang, J.S. 1996: PEP38413 seismic interpretation report offshore south Taranaki, New Zealand. Petroleum Report Series PR2236. Ministry of Economic Development. 


\section{Appendix A New Zealand Neogene Timescale}

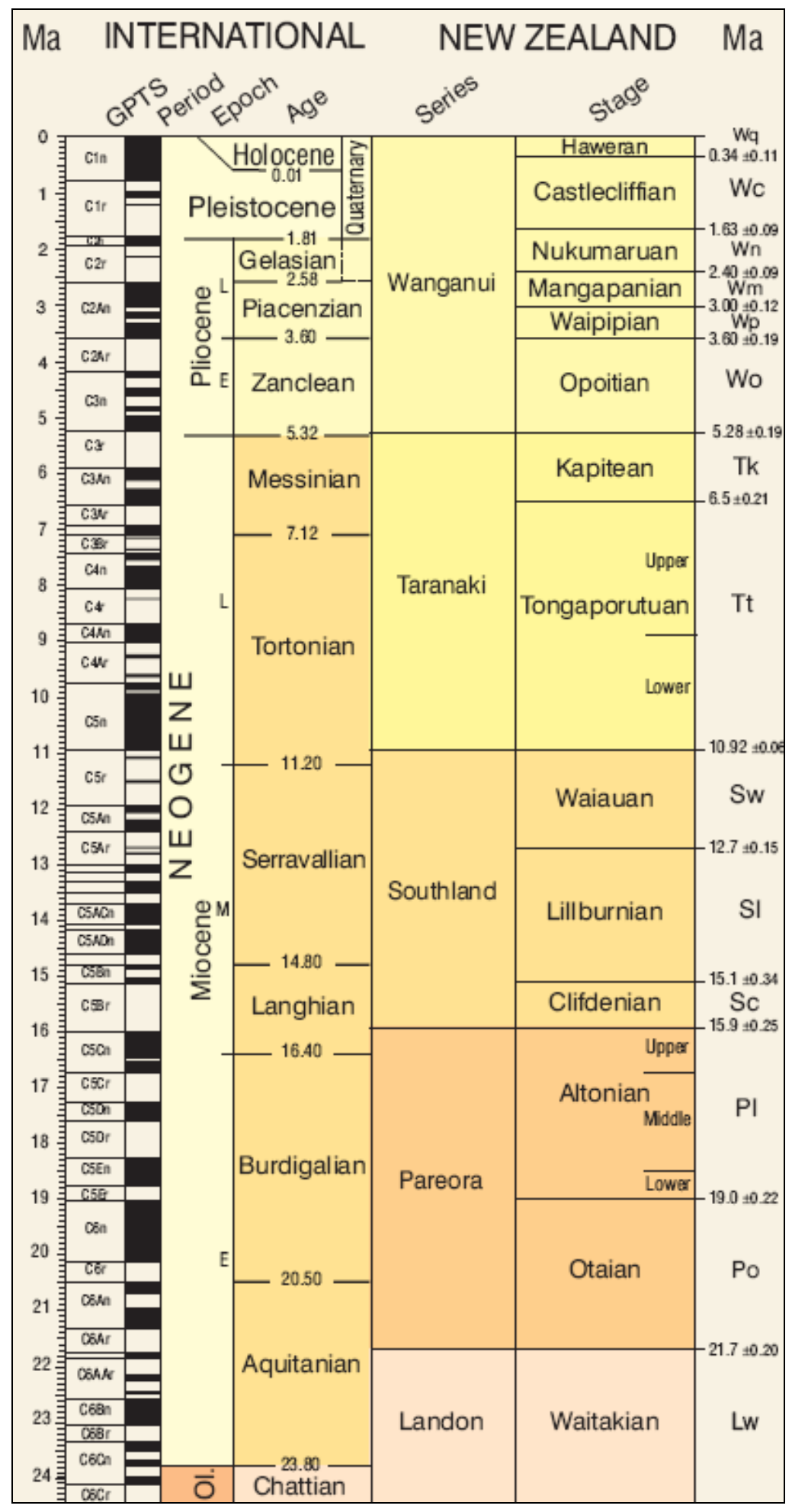

Modified from Cooper (2004) 


\section{Appendix B Related petroleum and biostratigraphy reports}

Below is a list of unpublished petroleum and biostratigraphy reports that were used as part of this thesis. These reports are held by the Ministry of Economic Development, and are available on their website: www.crownminerals.govt.nz/petroleum.

Brand, R.P., Buchan, R.J., Mills, K.L. 1999: An assessment of the prospectivity of hydrocarbon traps in the footwall of the Taranaki Fault, PEP38729 onshore north Taranaki. Petroleum Report Series PR2502. Ministry of Economic Development.

Brewster, T., Crookbain, R., Deker, S. 2002: Seismic interpretation of 2D data in the southern part of PEP38413 Licence. Petroleum Report Series PR2725. Ministry of Economic Development.

Challis, G.A. 1990: Petrography of Miocene sandstones from Midhurst-1, Kapuni-1 and Kapuni9. Petroleum Report Series PR1532. Ministry of Economic Development.

Core Laboratories. 1989: Core analysis report for NZ Oil and Gas: Kapuni-9 PPL 38707. Petroleum Report Series PR2109. Ministry of Economic Development.

Core Laboratories. 2002: A special core analysis study of selected samples, Maari Field, New Zealand: Volume 2, Grain size and pore size analyses, well - Maari-1. Petroleum Report Series PR2687. Ministry of Economic Development.

Core Laboratories. 1993: An advanced rock property study of selected samples from the Mt Messenger and Moki Formations of wells Kaimiro-2 and -3 New Zealand. Petroleum Report Series PR1877. Ministry of Economic Development.
Crouch, E., Crundwell, M.P., Strong, C.P., Cook, R.A. 1994: Taranaki biostratigraphic well review: Phase 2. Geological and Nuclear Sciences Client Report 53450A

Crouch, E.M., Strong, C.P., Crundwell, M.P., Cook, R.A. 1994: Taranaki offshore well review, Biostratigraphic summary and assessment. Geological and Nuclear Sciences Client Report 533927.10

Crundwell et al. 1996: Quantitative biostratigraphic techniques: A pilot study from the Taranaki Basin. GNS Client report 54554A.10

Crundwell, M. 1994: Review of foraminiferal slides from Miocene intervals in Tasman, North Tasman, Maui-4 and Kea petroleum exploration wells. Institute of Geological and Nuclear Sciences Client Report 53453.A

Crundwell, M. 2000a: Biostratigraphic review of faunal slides from the Miocene section of Moki-2A Institute of Geological and Nuclear Sciences Client Report 2000/83.

Crundwell, M. 2000b: Biostratigraphic review of faunal slides from the Miocene section of Kea-1. Institute of Geological and Nuclear Sciences Client Report 2000/84.

Crundwell, M. 2000c: Biostratigraphic review of faunal slides from the Miocene section of Maui-2. Institute of Geological and Nuclear Sciences Client Report 2000/85. 
Crundwell, M. 2000d: Biostratigraphic review of faunal slides from the Miocene section of Maui-3. Institute of Geological and Nuclear Sciences Client Report 2000/86.

Crundwell, M.P. 1995: Late Miocene and Pliocene biostratigraphic well review offshore Taranaki. GNS Client Report 53453A-10

Davies, K. 1997: Reservoir quality of the Maanga, Mt Messenger and Moki sandstones in the Taranaki Basin and the implications for the Oakura prospect PEP 38712. Petroleum Report Series PR2311. Ministry of Economic Development

De Bock, J.F., Perry, S., Webby, D., Goodin, B. 1991: Appraisal of the Maui-4 and Moki-1 oil discoveries PML 38144 PML 38145. Petroleum Report Series PR1800. Ministry of Economic Development.

Digicon Geophysical Ltd. 1996: Tory marine seismic survey PEP 38470 T96 lines. Petroleum Report Series PR2307. Ministry of Economic Development.

Digicon Geophysical Ltd. 1997: Kiwa seismic reprocessing PEP 38460. Petroleum Report Series PR2308. Ministry of Economic Development

Digital Exploration Ltd. 1994: PEP 38413 seismic reprocessing programme seismic data processing report Taranaki Basin. Petroleum Report Series PR2115. Ministry of Economic Development.

Explore Digicon and Geco-Prakla. 1995: 1995 seismic survey Pike area PEP38413. Petroleum Report Series PR2125. Ministry of Economic Development.

Geco NZ. 1986: Seismic survey conducted in PPL38114 during January 1986. Petroleum Report Series PR1329. Ministry of Economic Development.
Geco NZ. 1988: Offshore Taranaki PPL38418 reprocessing. Petroleum Report Series PR1662. Ministry of Economic Development.

Geco NZ. 1998: Offshore Taranaki PPL38418 reprocessing. Petroleum Report Series PR1662. Ministry of Economic Development.

Geco Prakla Schlumberger. 1992: Maui margin blocks reprocessing programme PPL38441 and PPL38442. Petroleum Report Series PR 2123. Ministry of Economic Development.

Geco Prakla. 1991a: PML38144/145 Moki/Maui-4 1991 reprocessing. Petroleum Report Series PR1812. Ministry of Economic Development.

Geco Prakla. 1991b: 1991 seismic survey PPL38422, PPL38443 and PPL38444. Petroleum Report Series PR1948. Ministry of Economic Development.

Geco Prakla. 1991c: Seismic reprocessing PPL38422, PPL38443, PPL38444. Petroleum Report Series PR1949. Ministry of Economic Development.

Hayward, B.W., Raine, J.I. 1978: Biostratigraphy of North Tasman-1 offshore well. New Zealand Geological Survey Report PAL 30. Department of Scientific and Industrial Research.

Hayward, B.W., Raine, J.I. 1985: Biostratigraphy of Fresne-1 PPL 38119 offshore well near Cape Farewell. New Zealand Geological Survey Report Pal 101. Petroleum Report Series PR1130. Ministry of Economic Development.

Higgs, K.E. 2004: A petrographic and reservoir quality of the Moki Formation, Taranaki Basin. Institute of Geological and Nuclear Sciences file report 2004/02. Petroleum Report Series PR3005. Ministry of Economic Development. 
Higgs, K.E., Crouch, E., Crundwell, M. 2004:

Biostratigraphy and palaeoenvironmental interpretation of Pukeko-1 well, Taranaki Basin, New Zealand. Institute of Geological and Nuclear Sciences client report 2004/128.

Hornibrook, N. de B. 1969: The micropalaeontology of Maui-1 offshore well. In: Shell BP and Todd Oil Services. Maui-1 well resume. Unpublished petroleum report 540. Ministry of Economic Development.

Hornibrook, N. de B. 1976: Microfossil examinations by D.S.I.R. In: NZ Aquitaine Petroleum Ltd. Well completion report Fresne-1. Unpublished petroleum report 643. Ministry of Economic Development.

Horton, P. 2000: Structural evolution of the eastern margin of the southern Taranaki Peninsula, North Island, New Zealand. Petroleum Report Series PR2511. Ministry of Economic Development.

Jones, N., Buchan, R. 1998: Kate 2D marine survey PEP38460 and PEP 38466, K98 lines. Petroleum Report Series PR2366. Ministry of Economic Development.

Jordan, D.W. 1989: Core descriptions from the Moki-1 and -2A wells, offshore New Zealand with additional photographs, data and figures. PPL38114. Petroleum Report Series PR1781. Ministry of Economic Development.

Lock, R. 1985: The distribution, sedimentology and petroleum prospects of the Moki Formation, Taranaki Basin, New Zealand. Petroleum Report Series PR1150. Ministry of Economic Development.

Marathon Petroleum Ltd. 1991: Final geological report Motueka-1. Petroleum Report Series PR1685. Ministry of Economic Development.
Martin, K.R. 1990: Petrology and reservoir quality of the Moki Formation in Kapuni-9 and a comparison of Moki sandstones from Kapuni-9, Durham-1 and Burgess-1. Petroleum Report Series PR1645. Ministry of Economic Development.

Martin, K.R. 1991: Petrology and reservoir quality of the Moki Formation in Ngatoro-2, Taranaki Basin, New Zealand. Petroleum Report Series PR1918. Ministry of Economic Development.

Martin, K.R. 1993: Petrology and reservoir quality of the Moki Formation in Cardiff-1, PPL 38707, Taranaki Basin, New Zealand. Petroleum Report Series PR1975. Ministry of Economic Development.

Martin, K.R. 1995: Petrology, diagenesis and reservoir quality of the Moki Formation in Mystone1, PPL 38705, Taranaki Basin, New Zealand. Petroleum Report Series PR2187. Ministry of Economic Development.

Matschke, G., Weber, J. 1979: Marine seismic survey PPL682 report on digital data processing. Petroleum Report Series PR627. Ministry of Economic Development.

Matthews, E. 1989: Reassessment of Moki Sand Play. Petroleum Report Series PR2385. Ministry of Economic Development.

Matthews, E., Mills, K. 2001: The effect of burial on the porosity and permeability of Miocene sandstones in the Taranaki Basin. Petroleum Report Series PR2623. Ministry of Economic

Development.

Morgans, H.E.G., Wilson, G.J., Mildenhall, D.C., Strong, C.P. 1991: Review of the Lower Section of the Tasman-1 and North Tasman-1 Offshore well, North Tasman Bay/South Taranaki Bight Area. DSIR Geology and Geophysics Contract Report 1999/11. 
New Zealand Oil and Gas. 1984: Witiora-1 well completion report PPL 38113 offshore Taranaki. Petroleum Report Series PR1037. Ministry of Economic Development.

New Zealand Oil and Gas. 1987: Kupe South-1 well completion report PPL 38116. Petroleum Report Series PR1284. Ministry of Economic Development.

New Zealand Oil and Gas. 2004: Hochstetter-1 well completion report PEP 38460 offshore Taranaki Basin. Petroleum Report Series PR2524. Ministry of Economic Development.

New Zealand Overseas Petroleum Ltd. 2003: Tui-1 well completion report. Petroleum Report Series PR2784. Ministry of Economic Development.

New Zealand Overseas Petroleum Ltd. 2004: Pukeko-1 well completion report. Petroleum Report Series PR2928. Ministry of Economic Development.

NZ Aquitaine Petroleum Ltd. 1970a: Tasman-1 well completion report. Petroleum Report Series PR512. Ministry of Economic Development.

NZ Aquitaine Petroleum Ltd. 1970b: Cook-1 well completion report PPL693. Petroleum Report Series PR513. Ministry of Economic Development

NZ Aquitaine Petroleum Ltd. 1976a: Well completion report Fresne-1. Petroleum Report Series PR674. Ministry of Economic Development.

NZ Aquitaine Petroleum Ltd. 1976b: Well completion report Surville-1. Petroleum Report Series PR677. Ministry of Economic Development.

NZ Aquitaine Petroleum Ltd. 1979: North Tasman1 well completion report. Petroleum Report Series PR736. Ministry of Economic Development.
OMV New Zealand Ltd. 2002: PEP38472 2002 reprocessing. Petroleum Report Series PR2992. Ministry of Economic Development.

Petrocorp Exploration Ltd. 1984: Tahi-1 well completion report PPL38116. Petroleum Report Series PR1030. Ministry of Economic

Development.

Petrocorp Exploration Ltd. 1988: Te Whatu 1,2 well completion report. Petroleum Report Series PR1345. Ministry of Economic Development.

Petrocorp Exploration Ltd. 1995: Offshore 2D seismic survey 1995/1996 P95 lines PPL38455, PPL38456, PPL38457, PPL38458, PPL38459. Petroleum Report Series PR2261. Ministry of Economic Development.

Pocknall, D.T., Scott, G.H. 1984: Biostratigraphy of Moki-1 offshore well. New Zealand Geological Survey Report PAL 70.

Schroeder, A.G. 1970b: The micropalaeontology of Maui-2 offshore well. In: Shell BP and Todd Oil Services. Maui-2 Well Resume. Unpublished petroleum report 541. Ministry of Economic Development

Schroeder, A.J. 1970a: The micropalaeontology of Tasman-1 offshore well. In: NZ Aquitaine Petroleum Ltd. Tasman-1 well completion report. Unpublished Petroleum Report 512. Ministry of Economic Development.

Schroeder, A.J. 1970c: The micropalaeontology of Maui-3 offshore well. In: Shell BP and Todd Oil Services. Well resume Maui-3. Unpublished petroleum report 542. Ministry of Economic Development.

Schroeder, A.J. 1970d: The micropalaeontology of Maui-4 offshore well. In: Shell BP and Todd Oil Services. Well resume Maui-4. Unpublished petroleum report 543. Ministry of Economic Development. 
Scott, G.H. 1985: Biostratigraphic revision of Maui-2 offshore well south Taranaki Basin. New Zealand Geological Survey report PAL 99.

Department of Scientific and Industrial Research.

Scott, G.H. 1986: Revision of foraminiferal biostratigraphy of Maui-4 offshore well south Taranaki Basin. New Zealand Geological Survey Report PAL 111. Department of Scientific and Industrial Research.

Scott, G.H. 1990: Biostratigraphy of Motueka offshore well, southern Taranaki Basin. DSIR Geology and Geophysics Contract Report 1990/34.

Shell BP and Todd Oil Services Ltd. 1969: Maui-1 well resume. Petroleum Report Series PR540.

Ministry of Economic Development

Shell BP and Todd Oil Services Ltd. 1970a: Well resume Maui-2. Petroleum Report Series PR541. Ministry of Economic Development.

Shell BP and Todd Oil Services Ltd. 1970b: Well resume Maui-3. Petroleum Report Series PR542. Ministry of Economic Development.

Shell BP and Todd Oil Services Ltd. 1970c: Well resume Maui-4. Petroleum Report Series PR543. Ministry of Economic Development.

Shell BP and Todd Oil Services Ltd. 1976: Well resume Kupe-1. Petroleum Report Series PR662. Ministry of Economic Development.

Shell BP and Todd Oil Services Ltd. 1982: Well resume Kiwa-1 PPL38055. Petroleum Report Series PR880. Ministry of Economic Development.

Shell BP and Todd Oil Services Ltd. 1986: Well resume Maui-5 PML381012 Taranaki, New Zealand. Petroleum Report Series PR 1182. Ministry of Economic Development
Shell BP and Todd Oil Services Ltd. 1987: Well resume Maui-7 PML381012 Taranaki, New Zealand. Petroleum Report Series PR1218. Ministry of Economic Development.

Shell Petroleum Mining Exploration Consultancy Group. 2002: Licence PEP38474 technical evaluation. Petroleum Report Series 2708. Ministry of Economic Development.

Shell Todd Oil Service: 1999c: Maui 3D reprocessing 1999. Petroleum Report Series PR2546. Ministry of Economic Development.

Shell Todd Oil Services. 1993: MB-Z(11) well completion report, Maui B Field, PML381012. Petroleum Report Series PR1911. Ministry of Economic Development.

Shell Todd Oil Services. 1994: MB-P(8) well completion report, Maui B Field, PML381012 offshore Taranaki Basin. Petroleum Report Series PR2018. Ministry of Economic Development.

Shell Todd Oil Services. 1996: Rahi-1 well completion report PML381012. Petroleum Report Series PR2277. Ministry of Economic Development.

Shell Todd Oil Services. 1999a: Maari-1 and -1A well completion report, PPL 38413. Petroleum Report Series PR1572. Ministry of Economic Development.

Shell Todd Oil Services: 1999b: Maui South-1 well completion report PML 301012. Petroleum Report Series PR2254. Ministry of Economic Development.

Simon Horizon Australia. 1992: 1992 seismic reprocessing PPL 38406 PPl 38407. Petroleum Report Series PR1987. Ministry of Economic Development. 
Strong, C.P. and Raine, J.I. 1985: Biostratigraphy of Kea-1 offshore well. New Zealand Geological Survey Report PAL 88.

Strong, C.P., Mildenhall, D.C., Scott, G.H. 1988: Biostratigraphy of Te Whatu-1 and -2 offshore petroleum exploration wells, southwestern Taranaki Basin. New Zealand Geological Survey Report PAL 128. Petroleum Report Series PR1380. Ministry of Economic Development.

Strong, C.P., Mildenhall, D.C., Scott, G.H. 1988: Biostratigraphy of Te Whatu $1 \& 2$ offshore petroleum exploration wells, southwestern Taranaki Basin. NZGS Report PAL 128

TCPL Resources Ltd. 1987: Kupe South-2 well completion report PPL38116. Petroleum Report Series PR1285. Ministry of Economic Development.

TCPL Resources Ltd. 1988: Kupe South-3/-3A/-3B well completion report PPL38116. Petroleum Report Series PR1368. Ministry of Economic Development.

TCPL Resources Ltd. 1989: Kupe South-4 well completion report PPL38116. Petroleum Report Series PR1483. Ministry of Economic Development.

TCPL Resources Ltd. 1991a: Toru-1 well completion report PPL38116. Petroleum Report Series PR1668. Ministry of Economic Development.

TCPL Resources Ltd. 1991b: Kupe South-5 well completion report PPL38116. Petroleum Report Series PR1678. Ministry of Economic Development.

Tricentrol Exploration Overseas Ltd. 1981: Marine seismic survey PPL38114 offshore Taranaki. Petroleum Report Series PR852. Ministry of Economic Development.
Tricentrol Exploration Overseas Ltd. 1983: PPL38114 NZ Interpretation report 1982 seismic data. Petroleum Report Series PR943. Ministry of Economic Development.

Tricentrol Exploration Overseas Ltd. 1984: Well completion report Moki-1 PPL 38114. Petroleum Report Series PR987. Ministry of Economic Development.

Tricentrol Exploration Overseas Ltd. 1985a: Well Completion Report Kea-1 PPL38114. Petroleum Report Series PR1089. Ministry of Economic Development.

Tricentrol Exploration Overseas Ltd. 1985b: Well Completion Report Moki-2 and Moki-2A. Petroleum Report Series PR1100. Ministry of Economic Development.

Western Geophysical. 1996: Reprocessed seismic lines, offshore southern Taranaki Basin PEP38456. Petroleum Report Series PR2306. Ministry of Economic Development.

Whitestone NZ Ltd. 1985: Reprocessed seismic data in the Taranaki Basin area PPL38119. Petroleum Report Series PR1358. Ministry of Economic Development.

Whitestone NZ Ltd. 1987: Cape Farewell-1 well completion report PPL 38119. Petroleum Report Series PR1234. Ministry of Economic Development.

Woodward, D. 1997: Reprocessing of data from PEP38460 offshore Taranaki. Petroleum Report Series PR2338. Ministry of Economic Development.

Yang, J.S., 1996: PEP38413 seismic interpretation report offshore south Taranaki Basin, New Zealand. Petroleum Report Series PR 2236. Ministry of Economic Development. 


\section{Appendix C Seismic lines}

This appendix gives a listing of the seismic surveys and the lines reviewed for this project.

\begin{tabular}{|c|c|c|c|c|c|}
\hline Survey Name & Line Number & Processing report & Survey Name & Line Number & Processing report \\
\hline \multirow[t]{3}{*}{$80 \mathrm{e}$} & 100 & PR 1662 & & 37 & \\
\hline & 101 & PR 1662 & & 38 & \\
\hline & 102 & PR 1662 & & 39 & \\
\hline \multirow[t]{8}{*}{$80 \mathrm{ma}$} & 101 & PR 2308 & & 40 & \\
\hline & 102 & PR 2308 & & 41 & \\
\hline & 103 & PR 2308 & & 42 & \\
\hline & 104 & PR 2308 & & 43 & \\
\hline & 105 & scanned & & $44 a$ & \\
\hline & $107 \_1$ & scanned & & 45 & \\
\hline & $107 \_2$ & scanned & & 46 & \\
\hline & 108 & PR 2308 & & 47 & \\
\hline \multirow[t]{35}{*}{$86 \mathrm{ma}$} & 1 & & & 48 & \\
\hline & 2 & & & 49 & \\
\hline & 4 & & & 50 & \\
\hline & 5 & & & 51 & \\
\hline & 6 & & & 52 & \\
\hline & 7 & & & 53 & \\
\hline & 8 & & & 54 & \\
\hline & 9 & & & 55 & \\
\hline & 10 & & & 56 & \\
\hline & 11 & & & 57 & \\
\hline & 12 & & & 58 & \\
\hline & 13 & & & 59 & \\
\hline & 14 & & & 60 & \\
\hline & 15 & & & 61 & \\
\hline & 16 & & & 62 & \\
\hline & 17 & & & 63 & \\
\hline & 18 & & & 64 & \\
\hline & 19 & & & 65 & \\
\hline & 20 & & & 66 & \\
\hline & 21 & & & 67 & \\
\hline & 22 & & & 68 & \\
\hline & 23 & & & 69 & \\
\hline & 24 & & & 70 & \\
\hline & 25 & & & 71 & \\
\hline & 26 & & & 72 & \\
\hline & 27 & & & 73 & \\
\hline & 28 & & & 74 & \\
\hline & 29 & & & 75 & \\
\hline & 30 & & & 76 & \\
\hline & 31 & & & 77 & \\
\hline & 32 & & & 79 & \\
\hline & 33 & & & 81 & \\
\hline & 34 & & & 83 & \\
\hline & 35 & & & 101 & \\
\hline & 36 & & & 102 & \\
\hline
\end{tabular}




\begin{tabular}{|c|c|c|c|c|c|}
\hline Survey Name & Line Number & Processing report & Survey Name & Line Number & Processing report \\
\hline & 103 & & & 13 & PR 2125 \\
\hline & $103 a$ & & & 14 & PR 2125 \\
\hline & 104 & & & 15 & PR 2125 \\
\hline & 105 & & & 16 & PR 2125 \\
\hline 91ce & 3 & PR 2306 & & 17 & PR 2125 \\
\hline as & 9 & PR 3254 & & 18 & PR 2125 \\
\hline \multirow[t]{17}{*}{ ce89 } & 2 & PR 2306 & & 19 & PR 2125 \\
\hline & 3 & & ds2-82 & $1 \mathrm{a}$ & PR 3254 \\
\hline & 4 & & & $3 a$ & PR 3254 \\
\hline & 5 & & & 6 & PR 3254 \\
\hline & 7 & & & 7 aа & PR 3254 \\
\hline & 8 & & & $9 a$ & PR 3254 \\
\hline & 9 & & & $9 b$ & PR 3254 \\
\hline & 11 & & & 11 aa & PR 3254 \\
\hline & 13 & & & $11 a b$ & PR 3254 \\
\hline & 15 & & & 13 & PR 3254 \\
\hline & 19 & & & $13 b$ & PR 3254 \\
\hline & 21 & & & 18 & PR 3254 \\
\hline & 23 & PR 2306 & & $20 a$ & PR 3254 \\
\hline & 25 & & & $20 \mathrm{~b}$ & PR 3254 \\
\hline & 27 & & & $24 a$ & PR 3254 \\
\hline & 29 & & & $24 b$ & PR 3254 \\
\hline & 31 & & & $28 a$ & PR 3254 \\
\hline \multirow[t]{17}{*}{ CS } & $5 a$ & PR 3254 & & $28 b$ & PR 3254 \\
\hline & $5 b$ & PR 3254 & fs & $1 \mathrm{a}$ & PR 3254 \\
\hline & $6 a$ & PR 3254 & & $1 b$ & PR 3254 \\
\hline & $6 b$ & PR 3254 & & $2 a$ & PR 3254 \\
\hline & $7 a$ & PR 3254 & & $2 b$ & PR 3254 \\
\hline & $7 \mathrm{~b}$ & PR 3254 & & $3 a$ & PR 3254 \\
\hline & $8 a$ & PR 3254 & & $3 b$ & PR 3254 \\
\hline & $8 b$ & PR 3254 & & 4 & PR 3254 \\
\hline & $9 a$ & PR 3254 & & $4 w$ & PR 3254 \\
\hline & $9 b$ & PR 3254 & & 5 & PR 3254 \\
\hline & $12 a$ & PR 3254 & & $5 w$ & PR 3254 \\
\hline & 16 & PR 3254 & & 6 & PR 3254 \\
\hline & 17 & PR 3254 and fugro & & 8 & PR 3254 \\
\hline & 18 & PR 3254 and fugro & & 1-fugro & PR 3254 \\
\hline & $20 a$ & PR 3254 & & 17 & fugro \\
\hline & $20 \mathrm{~b}$ & PR 3254 & & $18 \_1$ & PR 3254 \\
\hline & 6 & fugro & & 18_2 & PR 3254 \\
\hline \multirow[t]{12}{*}{ ct95 } & 1 & PR 2125 & & $19 a$ & PR 3254 \\
\hline & 2 & PR 2125 & & $21 \_1$ & fugro \\
\hline & 3 & PR 2125 & & 21_2 & fugro \\
\hline & 4 & PR 2125 & & 22_s1 & PR 3254 \\
\hline & 5 & PR 2125 & & 22_s2 & PR 3254 \\
\hline & 6 & PR 2125 & & 23 & fugro \\
\hline & 7 & PR 2125 & & 24_1 & fugro \\
\hline & 8 & PR 2125 & & 24_2 & fugro \\
\hline & 9 & PR 2125 & & 3 & fugro \\
\hline & 10 & PR 2125 & & 4 & fugro \\
\hline & 11 & PR 2125 & & 5 & fugro \\
\hline & 12 & PR 2125 & g & 6 & PR 3254 \\
\hline
\end{tabular}




\begin{tabular}{|c|c|c|}
\hline Survey Name & Line Number & Processing report \\
\hline \multirow[t]{3}{*}{$\mathrm{h}$} & $2 \mathrm{a}$ & PR 3254 \\
\hline & $4 a$ & PR 3254 \\
\hline & $13 a$ & PR 3254 \\
\hline \multirow[t]{47}{*}{ hzt82a } & 100 & PR 2992 \\
\hline & 101 & PR 2992 \\
\hline & 102 & PR 2992 \\
\hline & 103 & PR 2992 \\
\hline & 104 & PR 2992 \\
\hline & 105 & PR 2992 \\
\hline & 106 & PR 2992 \\
\hline & 107 & PR 2992 \\
\hline & 108 & PR 2992 \\
\hline & 109 & PR 2992 \\
\hline & 110 & PR 2992 \\
\hline & 111 & PR 2992 \\
\hline & 112 & PR 2992 \\
\hline & 113 & PR 2992 \\
\hline & 114 & PR 2992 \\
\hline & 115 & PR 2992 \\
\hline & 116 & PR 2992 \\
\hline & 117 & PR 2992 \\
\hline & 118 & PR 2992 \\
\hline & 119 & PR 2992 \\
\hline & 120 & PR 2992 \\
\hline & 121 & PR 2992 \\
\hline & 122 & PR 2992 \\
\hline & 123 & PR 2992 \\
\hline & 124 & PR 2992 \\
\hline & 125 & PR 2992 \\
\hline & 126 & PR 2992 \\
\hline & 127 & PR 2992 \\
\hline & 128 & PR 2992 \\
\hline & 129 & PR 2992 \\
\hline & 130 & PR 2992 \\
\hline & 131 & PR 2992 \\
\hline & 132 & PR 2992 \\
\hline & 133 & PR 2992 \\
\hline & 134 & PR 2992 \\
\hline & 135 & PR 2992 \\
\hline & 136 & PR 2992 \\
\hline & 137 & PR 2992 \\
\hline & 138 & PR 2992 \\
\hline & 139 & PR 2992 \\
\hline & 140 & PR 2992 \\
\hline & 142 & PR 2992 \\
\hline & 144 & PR 2992 \\
\hline & 146 & PR 2992 \\
\hline & 148 & PR 2992 \\
\hline & 150 & PR 2992 \\
\hline & 152 & PR 2992 \\
\hline \multirow[t]{3}{*}{ k98 } & 1 & PR 2366 \\
\hline & 10 & PR 2366 \\
\hline & 11 & PR 2366 \\
\hline
\end{tabular}

\begin{tabular}{|c|c|c|}
\hline Survey Name & Line Number & Processing report \\
\hline & 12 & PR 2366 \\
\hline & 13 & PR 2366 \\
\hline & 14 & PR 2366 \\
\hline & 16 & PR 2366 \\
\hline & 18 & PR 2366 \\
\hline & 19 & PR 2366 \\
\hline & 2 & PR 2366 \\
\hline & 20 & PR 2366 \\
\hline & 21 & PR 2366 \\
\hline & 22 & PR 2366 \\
\hline & 23 & PR 2366 \\
\hline & 24 & PR 2366 \\
\hline & 25 & PR 2366 \\
\hline & 27 & PR 2366 \\
\hline & 29 & PR 2366 \\
\hline & 3 & PR 2366 \\
\hline & 31 & PR 2366 \\
\hline & 33 & PR 2366 \\
\hline & 35 & PR 2366 \\
\hline & 37 & PR 2366 \\
\hline & 39 & PR 2366 \\
\hline & 4 & PR 2366 \\
\hline & 41 & PR 2366 \\
\hline & 43 & PR 2366 \\
\hline & 45 & PR 2366 \\
\hline & 47 & PR 2366 \\
\hline & 5 & PR 2366 \\
\hline & 6 & PR 2366 \\
\hline & 7 & PR 2366 \\
\hline & 8 & PR 2366 \\
\hline & 9 & PR 2366 \\
\hline
\end{tabular}

\begin{tabular}{ll}
\hline kw88 & 1 \\
& 3 \\
& 4 \\
& 5 \\
& 6 \\
& 7 \\
& 8 \\
& 9 \\
& 10 \\
& 11 \\
& 12 \\
& 13 \\
\hline Maari3D & \\
\hline Maui3D & \\
\hline mauiC & $\mathrm{c} 4$ \\
& $\mathrm{c} 4 \mathrm{ext}$ \\
mauiD & $\mathrm{d} 4$ 2 \\
mauiE & e6 \\
mauiF & $\mathrm{f} 10$ \\
mauiF & $\mathrm{f} 26$ \\
&
\end{tabular}




\begin{tabular}{|c|c|c|c|c|c|}
\hline Survey Name & Line Number & Processing report & Survey Name & Line Number & Processing report \\
\hline mauiG & g2 & PR 2992 & & 406 & PR 2261 \\
\hline moho & & & & 407 & PR 2261 \\
\hline mohoa & & & & 408 & PR 2261 \\
\hline \multirow[t]{14}{*}{$\mathrm{nm}$} & $10 \_1$ & PR 2708 & & 409 & PR 2261 \\
\hline & $10 \_2$ & PR 2708 & & 411 & PR 2261 \\
\hline & $12 \_1$ & PR 2708 & & 412 & PR 2261 \\
\hline & $12 \_2$ & PR 2708 & & 414 & PR 2261 \\
\hline & 13 & PR 2708 & & 416 & PR 2261 \\
\hline & 16 & PR 2708 & & 418 & PR 2261 \\
\hline & $19 \_1$ & PR 2708 & & 420 & PR 2261 \\
\hline & $19 \_2$ & PR 2708 & & 422 & PR 2261 \\
\hline & $2 \_0$ & PR 2708 & & 424 & PR 2261 \\
\hline & $2 \_1$ & PR 2708 & & 426 & PR 2261 \\
\hline & 20_1 & PR 2708 & & 428 & PR 2261 \\
\hline & 30 & PR 2708 & & 430 & PR 2261 \\
\hline & 31 & PR 2708 & & 434 & PR 2261 \\
\hline & 35 & PR 2708 & & 436 & PR 2261 \\
\hline \multirow[t]{4}{*}{ nt76 } & 5 & PR 3254 & & 438 & PR 2261 \\
\hline & 6 & PR 3254 & & 440 & PR 2261 \\
\hline & $7 a$ & PR 3254 & & 442 & PR 2261 \\
\hline & $8 a$ & PR 3254 & & $444 c$ & PR 2261 \\
\hline \multirow[t]{3}{*}{ nt89 } & 3 & PR 3254 & & $445 c$ & PR 2261 \\
\hline & 4 & PR 3254 & & 450 & PR 2261 \\
\hline & 5 & PR 3254 & ps & 14 & PR 3254 \\
\hline \multirow[t]{6}{*}{ nt90 } & 1 & PR 3254 & & 17 & PR 3254 \\
\hline & 2 & PR 3254 & & 18 & PR 3254 \\
\hline & 3 & PR 3254 & & 19 & PR 3254 \\
\hline & 4 & PR 3254 & & 26 & PR 3254 \\
\hline & 5 & PR 3254 & $s 1382$ & 1 & PR 2708 \\
\hline & 6 & PR 3254 & & 3 & PR 2708 \\
\hline \multirow[t]{14}{*}{ or03 } & 1 & PR 2794 & & 4 & PR 2708 \\
\hline & 2 & PR 2794 & & 5 & PR 2708 \\
\hline & 3 & PR 2794 & & 6 & PR 2708 \\
\hline & 4 & PR 2794 & & 7 & PR 2708 \\
\hline & 5 & PR 2794 & & $8 a$ & PR 2306 \\
\hline & 6 & PR 2794 & & 9 & PR 2308 \\
\hline & 7 & PR 2794 & & 10 & PR 2308 \\
\hline & 8 & PR 2794 & & 11 & PR 2308 \\
\hline & 9 & PR 2794 & & 12 & PR 2308 \\
\hline & 10 & PR 2794 & & 14 & PR 2306 \\
\hline & 11 & PR 2794 & & 15 & PR 2708 \\
\hline & 12 & PR 2794 & & 101 & PR 2308 \\
\hline & 13 & PR 2794 & & 102 & PR 2308 \\
\hline & 14 & PR 2794 & & 103 & PR 2308 \\
\hline \multirow[t]{3}{*}{ p95 } & $1 \mathrm{a}$ & PR 2708 & & 104 & PR 2308 \\
\hline & $1 \mathrm{e}$ & PR 2708 & & 105 & PR 2708 \\
\hline & $1 \mathrm{~s}$ & PR 2708 & & $105 a$ & PR 2308 \\
\hline \multirow[t]{6}{*}{ P95 } & 400 & PR 2261 & & 106 & PR 2708 \\
\hline & 401 & PR 2261 & & $106 \mathrm{~b}$ & PR 2306 \\
\hline & 402 & PR 2261 & & 107 & PR 2708 \\
\hline & 403 & PR 2261 & & 108 & PR 2708 \\
\hline & 405 & PR 2261 & & 109 & PR 2708 \\
\hline & & & & 110 & PR 2708 \\
\hline
\end{tabular}




\begin{tabular}{|c|c|c|c|c|c|}
\hline Survey Name & Line Number & Processing report & Survey Name & Line Number & Processing report \\
\hline & 111 & PR 2708 & & 218 & \\
\hline & 113 & PR 2306 & & 220 & \\
\hline \multirow[t]{10}{*}{ s1383 } & $209 a$ & PR 2123 & & 224 & \\
\hline & $209 b$ & PR 2306 & & 226 & \\
\hline & $210 a$ & PR 2123 & & 230 & \\
\hline & $210 b$ & PR 2306 & & 234 & \\
\hline & 211 & PR 2123 & & 238 & \\
\hline & 306 & PR 2123 & & 242 & \\
\hline & 307 & PR 2123 & & 244 & \\
\hline & 308 & PR 2306 & & 246 & \\
\hline & 311 & PR 2306 & & 248 & \\
\hline & 312 & PR 2708 & & 250 & \\
\hline \multirow[t]{3}{*}{ s74 } & 10 & PR 3254 & & 252 & \\
\hline & 16 & PR 3254 & & 254 & \\
\hline & $17 a$ & PR 3254 & & 256 & \\
\hline \multirow[t]{2}{*}{ s89 } & $4 a$ & PR 3254 & & 300 & \\
\hline & 5 & PR 3254 & & 301 & \\
\hline \multirow[t]{16}{*}{ S94 } & 201 & & sunz91 & 101 & PR 1948 \\
\hline & 202 & & & 102 & PR 1948 \\
\hline & 203 & & & 103 & PR 1948 \\
\hline & 204 & & & 104 & PR 1948 \\
\hline & 205 & & & 105 & PR 1948 \\
\hline & 206 & & & 106 & PR 1948 \\
\hline & 207 & & & 107 & PR 1948 \\
\hline & 208 & & & 108 & PR 1948 \\
\hline & 209 & & & 109 & PR 1948 \\
\hline & 212 & & & 110 & PR 1948 \\
\hline & 214 & & & 111 & PR 1948 \\
\hline & 216 & & & 112 & PR 1948 \\
\hline & 218 & & & 113 & PR 1948 \\
\hline & 220 & & & 114 & PR 1948 \\
\hline & 222 & & & 115 & PR 1948 \\
\hline & 224 & & & 116 & PR 1948 \\
\hline \multirow[t]{20}{*}{ stos95 } & 100 & & & 117 & PR 1948 \\
\hline & 102 & & & 118 & PR 1948 \\
\hline & 104 & & & 119 & PR 1948 \\
\hline & 106 & & & 120 & PR 1948 \\
\hline & 108 & & & 121 & PR 1948 \\
\hline & 110 & & & 122 & PR 1948 \\
\hline & 112 & & & 123 & PR 1948 \\
\hline & 114 & & & 124 & PR 1948 \\
\hline & 116 & & & 125 & PR 1948 \\
\hline & 190 & & & 126 & PR 1948 \\
\hline & 194 & & & 127 & PR 1948 \\
\hline & 200 & & & 128 & PR 1948 \\
\hline & 202 & & & 129 & PR 1948 \\
\hline & 204 & & & 130 & PR 1948 \\
\hline & 206 & & & 131 & PR 1948 \\
\hline & 208 & & & 133 & PR 1948 \\
\hline & 212 & & & 134 & PR 1948 \\
\hline & 214 & & & 135 & PR 1948 \\
\hline & 216 & & & 136 & PR 1948 \\
\hline & & & & 137 & PR 1948 \\
\hline
\end{tabular}




\begin{tabular}{|c|c|c|c|c|c|}
\hline Survey Name & Line Number & Processing report & Survey Name & Line Number & Processing report \\
\hline & 138 & PR 1948 & & 24 & PR 2307 \\
\hline & 139 & PR 1948 & & 25 & PR 2307 \\
\hline & 140 & PR 1948 & & 26 & PR 2307 \\
\hline & 141 & PR 1948 & & 27 & PR 2307 \\
\hline & 142 & PR 1948 & & 29 & PR 2307 \\
\hline & 143 & PR 1948 & & 30 & PR 2307 \\
\hline & 144 & PR 1948 & & 31 & PR 2307 \\
\hline & 145 & PR 1948 & & 32 & PR 2307 \\
\hline & 146 & PR 1948 & & 33 & PR 2307 \\
\hline & 147 & PR 1948 & & 35 & PR 2307 \\
\hline & 148 & PR 1948 & & 37 & PR 2307 \\
\hline & 149 & PR 1948 & & 39 & PR 2307 \\
\hline & 150 & PR 1948 & & 41 & PR 2307 \\
\hline & 151 & PR 1948 & & 43 & PR 2307 \\
\hline & 152 & PR 1948 & & 45 & PR 2307 \\
\hline & 153 & PR 1948 & & 47 & PR 2307 \\
\hline & 154 & PR 1948 & & 49 & PR 2307 \\
\hline & 155 & PR 1948 & & 51 & PR 2307 \\
\hline & 156 & PR 1948 & & 53 & PR 2307 \\
\hline & 157 & PR 1948 & $\operatorname{tnz81}$ & 601 & PR 2115 \\
\hline & 158 & PR 1948 & & 602 & PR 852 \\
\hline & 159 & PR 1948 & & 603 & PR 852 \\
\hline & 160 & PR 1948 & & 604 & PR 3254 \\
\hline & 161 & PR 1948 & & 605 & PR 2115 \\
\hline & 162 & PR 1948 & & 606 & PR 852 \\
\hline & 163 & PR 1948 & & 607 & PR 2115 \\
\hline & 164 & PR 1948 & & 608 & PR 852 \\
\hline & 165 & PR 1948 & & 609 & PR 852 \\
\hline & 166 & PR 1948 & & $610 a$ & PR 3254 \\
\hline & 167 & PR 1948 & & $610 p$ & PR 2115 \\
\hline \multirow[t]{23}{*}{ t96 } & 1 & PR 2307 & & 611 & PR 852 and PR 3254 \\
\hline & 2 & PR 2307 & & 612 & PR 1812 \\
\hline & 3 & PR 2307 & & 613 & PR 2115 \\
\hline & 4 & PR 2307 & & 614 & PR 2115 \\
\hline & 5 & PR 2307 & & $615 p$ & PR 2115 \\
\hline & 6 & PR 2307 & & 618 & PR 2338 \\
\hline & 7 & PR 2307 & & $618 a$ & PR 3254 \\
\hline & 8 & PR 2307 & & $618 p$ & PR 1987 and PR 2115 \\
\hline & 9 & PR 2307 & & 619 & PR 2115 \\
\hline & 10 & PR 2307 & & 620 & PR 852 \\
\hline & 11 & PR 2307 & & 621 & PR 852 \\
\hline & 12 & PR 2307 & & 622 & PR 852 \\
\hline & 13 & PR 2307 & & $622 p$ & PR 2115 \\
\hline & 14 & PR 2307 & & 623 & PR 2115 \\
\hline & 15 & PR 2307 & & 624 & PR 2115 \\
\hline & 16 & PR 2307 & & 625 & PR 852 \\
\hline & 17 & PR 2307 & & 626 & PR 2115 \\
\hline & 18 & PR 2307 & & 627 & PR 2115 \\
\hline & 19 & PR 2307 & & 628 & PR 2338 \\
\hline & 20 & PR 2307 & & $630 a$ & PR 2338 and PR 3254 \\
\hline & 21 & PR 2307 & & 631 & PR 852 \\
\hline & 22 & PR 2307 & & 632 & PR 2338 and PR 3254 \\
\hline & 23 & PR 2307 & & $635 a$ & PR 3254 \\
\hline
\end{tabular}




\begin{tabular}{|c|c|c|c|c|c|}
\hline Survey Name & Line Number & Processing report & Survey Name & Line Number & Processing report \\
\hline & $639 a$ & PR 3254 & & 524 & PR 2338 \\
\hline & $641 p$ & PR 1987 & $\operatorname{tnz} 86$ & 101 & PR 2115 \\
\hline & $643 p$ & PR 1987 & & 116 & PR 1329 \\
\hline & 645 & PR 2308 & & 118 & PR 1329 \\
\hline & $645 \mathrm{dl}$ & PR 852 & w83 & $1 \mathrm{c}$ & \\
\hline & $647 a$ & PR 2992 & & $2 c$ & \\
\hline & 651 & PR 852 & & $3 c$ & \\
\hline \multirow[t]{26}{*}{ tnz82 } & 400 & PR 943 & & $7 c$ & \\
\hline & 401 & PR 943 & & $8 c$ & \\
\hline & 402 & PR 943 & & $9 c$ & \\
\hline & 403 & PR 943 & & $1 \mathrm{a}$ & PR 3254 \\
\hline & 404 & PR 943 & & $2 a$ & PR 3254 \\
\hline & 405 & PR 943 and PR 2115 & & $2 b$ & PR 3254 \\
\hline & 406 & PR 943 & & $3 b$ & PR 3254 \\
\hline & 407 & PR 2338 & & $4 b$ & PR 3254 \\
\hline & 408 & PR 2338 & & $5 b$ & PR 3254 \\
\hline & 409 & PR 2338 & w84 & $11 f$ & PR 3254 \\
\hline & 410 & PR 2338 & & $1 \mathrm{t}$ & PR 1358 \\
\hline & 411 & PR 2338 & & $2 \mathrm{t}$ & PR 1358 \\
\hline & 412 & PR 2338 & & $3 t$ & PR 1358 \\
\hline & 413 & PR 2338 & & $101 f$ & PR 3254 \\
\hline & 414 & PR 2338 & & $103 t$ & PR 1358 \\
\hline & 416 & PR 2338 & & $104 f$ & PR 3254 \\
\hline & 418 & PR 2338 & & $104 t$ & PR 1358 \\
\hline & $418 a$ & PR 2338 & & $105 f$ & PR 1358 \\
\hline & 420 & PR 2338 & & $106 f$ & PR 1358 \\
\hline & 422 & PR 2338 & w85 & $1 n$ & PR 1358 \\
\hline & 424 & PR 2338 & & $3 n$ & PR 1358 \\
\hline & 426 & PR 2338 & wm & 1 & PR 3254 \\
\hline & $426 a$ & PR 2338 & & 10 & PR 1662 \\
\hline & 428 & PR 2338 & & $10 x$ & PR 1662 \\
\hline & 430 & PR 2115 & & 11 & PR 1662 \\
\hline & $430 a$ & PR 2115 & & $11 x$ & PR 1662 \\
\hline \multirow[t]{19}{*}{ tnz84 } & 500 & PR 2338 & & 12 & PR 1662 \\
\hline & 501 & PR 2338 & & $13 \_1$ & PR 2308 \\
\hline & 503 & PR 2338 & & $13 \_2$ & PR 1662 \\
\hline & 504 & PR 2338 & & $14 \_0$ & PR 1662 \\
\hline & 505 & PR 2338 & & $14 \_1$ & PR 2308 \\
\hline & 506 & PR 2338 & & 15_1 & PR 2123 \\
\hline & 507 & PR 2338 & & $19 \_1$ & PR 627 \\
\hline & 508 & PR 2338 & & $19 \_2$ & PR 627 \\
\hline & 509 & PR 2338 & & 2 & PR 627 \\
\hline & 510 & PR 2338 & & 20_0 & PR 1949 \\
\hline & 511 & PR 2338 & & 20_1 & PR 1949 \\
\hline & 512 & PR 2338 & & 22 & PR 1949 \\
\hline & 513 & PR 2338 & & 25 & PR 1949 \\
\hline & 514 & PR 2338 & & 28 & PR 2308 \\
\hline & 515 & PR 2338 & & 3 & PR 627 \\
\hline & 516 & PR 2338 & & 4 & PR 2308 \\
\hline & 518 & PR 2338 & & 5 & PR 2308 \\
\hline & 519 & PR 1987 & & 51 & PR 627 \\
\hline & 522 & PR 2115 & & $51 e$ & PR 2308 \\
\hline
\end{tabular}




\begin{tabular}{|c|c|c|c|c|c|}
\hline Survey Name & Line Number & Processing report & Survey Name & Line Number & Processing report \\
\hline & 54 & PR 1949 & & $61 \_2$ & PR 627 \\
\hline & 55 & PR 2308 & & 65 & PR 2308 \\
\hline & 56_0s & PR 627 & & $7 e$ & PR 1662 \\
\hline & $57 \_1$ & PR 2308 & & $7 w$ & \\
\hline & 58_0n & PR 1949 & & 8 & PR 2308 \\
\hline & 58_1s & & & $8 w$ & \\
\hline & 59 & PR 2308 & & 9 & PR 1662 \\
\hline & 6 & PR 2308 & & $9 x$ & PR 1662 \\
\hline
\end{tabular}




\section{Appendix D Well Data}

This appendix provides details of wells used in this study. All depths referred to are measured depth below rig datum (e.g. Kelly Bushing, Rotary Table or Drilling Floor)
a) general well data
b) velocity curves used
c) revised formation tops

\section{a) General well data}

Table 1: General well data. Eastings and Northings are referenced to New Zealand Map Grid and refer to the surface location of the well. T.D. = Total Depth (metres below datum elevation); $\mathrm{PR}=$ petroleum report number

\begin{tabular}{|c|c|c|c|c|c|c|c|c|}
\hline Well & PR & Year & Operator & NZMG E & NZMG N & TD & Target & Status \\
\hline $\begin{array}{l}\text { Cape } \\
\text { Farewell-1 }\end{array}$ & 1234 & 1987 & $\begin{array}{c}\text { Whitestone } \\
\text { NZ Ltd }\end{array}$ & 2484444.32 & 6078126.95 & 2817 & Pakawau Gp & $\begin{array}{l}\text { Plugged and } \\
\text { Abandoned }\end{array}$ \\
\hline Fresne-1 $1^{2}$ & 674 & 1976 & Aquataine & 2516733.65 & 6095020.19 & 2503 & Pakawau Gp & $\begin{array}{l}\text { Plugged and } \\
\text { Abandoned }\end{array}$ \\
\hline Hochstetter- $1^{2}$ & 2524 & 2000 & $\begin{array}{l}\text { New } \\
\text { Zealand Oil } \\
\text { and Gas }\end{array}$ & 2476240.80 & 6171779.17 & 3298 & $\begin{array}{l}\text { Kapuni Gp, } \\
\text { Moki Fm }\end{array}$ & $\begin{array}{c}\text { Plugged and } \\
\text { Abandoned }\end{array}$ \\
\hline Kea-1 ${ }^{1}$ & 1089 & 1985 & Tricentrol & 2539104.67 & 6147975.46 & 3138 & $\begin{array}{l}\text { Moki Fm, } \\
\text { Kapuni Gp }\end{array}$ & $\begin{array}{l}\text { Plugged and } \\
\text { Abandoned }\end{array}$ \\
\hline Kiwa-1 ${ }^{1}$ & 880 & 1982 & $\begin{array}{l}\text { Shell Todd } \\
\text { Oil } \\
\text { Services }\end{array}$ & 2484171.00 & 6155161.00 & 3858 & Kapuni Gp & $\begin{array}{l}\text { Plugged and } \\
\text { Abandoned }\end{array}$ \\
\hline Maari-1 ${ }^{1}$ & 1572 & 1999 & $\begin{array}{l}\text { Shell Todd } \\
\text { Oil } \\
\text { Services }\end{array}$ & 2535853.10 & 6137531.10 & 2200 & $\begin{array}{c}\text { Moki Fm, M2A } \\
\text { SST, Kapuni } \\
\text { Gp }\end{array}$ & Suspended \\
\hline Maui-1 ${ }^{1}$ & 540 & 1969 & $\begin{array}{l}\text { Shell Todd } \\
\text { Oil } \\
\text { Services }\end{array}$ & 2536619.56 & 6170695.56 & 3512 & Kapuni Gp & Gas producer \\
\hline Maui-2 ${ }^{1}$ & 541 & 1970 & $\begin{array}{l}\text { Shell Todd } \\
\text { Oil } \\
\text { Services }\end{array}$ & 2548629.65 & 6177085.44 & 3572 & Kapuni Gp & Gas producer \\
\hline Maui-3 ${ }^{1}$ & 542 & 1970 & $\begin{array}{l}\text { Shell Todd } \\
\text { Oil } \\
\text { Services }\end{array}$ & 2543111.84 & 6185595.42 & 3401 & Kapuni Gp & Gas producer \\
\hline Maui-4 ${ }^{1}$ & 543 & 1970 & $\begin{array}{l}\text { Shell Todd } \\
\text { Oil } \\
\text { Services }\end{array}$ & 2530568.62 & 6129714.52 & 3919 & Kapuni Gp & $\begin{array}{l}\text { Plugged and } \\
\text { Abandoned }\end{array}$ \\
\hline Maui- $5^{2}$ & 1182 & 1986 & $\begin{array}{l}\text { Shell Todd } \\
\text { Oil } \\
\text { Services }\end{array}$ & 2542373.90 & 6176484.30 & 3227 & Kapuni Gp & $\begin{array}{l}\text { Plugged and } \\
\text { Abandoned }\end{array}$ \\
\hline Maui- $7^{1}$ & 1218 & 1987 & $\begin{array}{l}\text { Shell Todd } \\
\text { Oil } \\
\text { Services }\end{array}$ & 2537550.4 & 6174455.3 & 3144 & Kapuni Gp & $\begin{array}{l}\text { Plugged and } \\
\text { Abandoned }\end{array}$ \\
\hline Maui B-6 & 2584 & 2000 & $\begin{array}{l}\text { Shell Todd } \\
\text { Oil } \\
\text { Services }\end{array}$ & 2537126.90 & 6173345.50 & 2154 & Kapuni Gp & Suspended \\
\hline Maui B-7 & 2594 & 2000 & $\begin{array}{l}\text { Shell Todd } \\
\text { Oil } \\
\text { Services }\end{array}$ & 2537123.20 & 6173345.10 & 3204 & Kapuni Gp & Sidetracked \\
\hline MB-P(8) ${ }^{1}$ & 2018 & 1994 & $\begin{array}{l}\text { Shell Todd } \\
\text { Oil } \\
\text { Services }\end{array}$ & 2537125.2 & 6173343.3 & 3709 & Kapuni Gp & Gas producer \\
\hline$M B-Z(11)^{2}$ & 1911 & 1993 & $\begin{array}{l}\text { Shell Todd } \\
\text { Oil } \\
\text { Services }\end{array}$ & 2537119.89 & 6173340.90 & 3100 & Kapuni Gp & Gas producer \\
\hline
\end{tabular}




\begin{tabular}{|c|c|c|c|c|c|c|c|c|}
\hline Well & PR & Year & Operator & NZMG E & NZMG N & TD & Target & Status \\
\hline Maui South-1 ${ }^{2}$ & 2254 & 1999 & $\begin{array}{l}\text { Shell Todd } \\
\text { Oil } \\
\text { Services }\end{array}$ & 2549188.40 & 6175873.7 & 2942 & Kapuni Gp & $\begin{array}{l}\text { Plugged and } \\
\text { Abandoned }\end{array}$ \\
\hline Moki-1 ${ }^{1}$ & 987 & 1984 & Tricentrol & 2536653.46 & 6137539.66 & 2624 & $\begin{array}{l}\text { Moki Fm, } \\
\text { Kapuni Gp }\end{array}$ & $\begin{array}{l}\text { Plugged and } \\
\text { Abandoned }\end{array}$ \\
\hline Moki-2A ${ }^{1}$ & 1100 & 1985 & Tricentrol & 2537185.39 & 6135179.90 & 1822 & Moki Fm & $\begin{array}{l}\text { Plugged and } \\
\text { Abandoned }\end{array}$ \\
\hline Motueka- $1^{2}$ & 1685 & 1991 & Marathon & 2550993.09 & 6075896.37 & 1567 & $\begin{array}{c}\text { Matapo SST } \\
\text { mbr, Kapuni } \\
\text { Gp }\end{array}$ & $\begin{array}{l}\text { Plugged and } \\
\text { Abandoned }\end{array}$ \\
\hline $\begin{array}{l}\text { North } \\
\text { Tasman- }{ }^{1}{ }^{1}\end{array}$ & 736 & 1979 & Aquataine & 2533188.43 & 6111919.03 & 2735 & $\begin{array}{l}\text { Pakawau Gp, } \\
\text { Moki Fm }\end{array}$ & $\begin{array}{l}\text { Plugged and } \\
\text { Abandoned }\end{array}$ \\
\hline Pukeko-1 $^{2}$ & 2928 & 2004 & $\begin{array}{c}\text { NZ } \\
\text { Overseas } \\
\text { Petroleum } \\
\text { Ltd }\end{array}$ & 2503224.07 & 6142713.90 & 4190 & Kapuni Gp & $\begin{array}{l}\text { Plugged and } \\
\text { Abandoned }\end{array}$ \\
\hline Rahi-1 $1^{2}$ & 2277 & 1997 & STOS & 2539461.80 & 6165421.20 & 3501 & $\begin{array}{l}\text { Kapuni Gp, } \\
\text { Moki Fm }\end{array}$ & $\begin{array}{l}\text { Plugged and } \\
\text { Abandoned }\end{array}$ \\
\hline Surville-1 ${ }^{2}$ & 677 & 1976 & Aquataine & 2547792.67 & 6053887.21 & 2202 & $\begin{array}{c}\text { Moki Fm, } \\
\text { Pakawau Gp }\end{array}$ & $\begin{array}{c}\text { Plugged and } \\
\text { Abandoned }\end{array}$ \\
\hline Tahi- ${ }^{1}$ & 1030 & 1984 & Petrocorp & 2609297.13 & 6124051.85 & 1776 & Pakawau Gp & $\begin{array}{l}\text { Plugged and } \\
\text { Abandoned }\end{array}$ \\
\hline Tasman-1 $1^{2}$ & 512 & 1970 & Aquataine & 2543698.83 & 6099154.3 & 1629 & Pakawau Gp & $\begin{array}{l}\text { Plugged and } \\
\text { Abandoned }\end{array}$ \\
\hline Te Whatu-2 ${ }^{1}$ & 1345 & 1988 & Petrocorp & 2508929.53 & 6126602.53 & 3542 & Kapuni Gp & $\begin{array}{l}\text { Plugged and } \\
\text { Abandoned }\end{array}$ \\
\hline Tui-1 ${ }^{2}$ & 2784 & 2003 & $\begin{array}{c}\text { NZ } \\
\text { Overseas } \\
\text { Petroleum } \\
\text { Ltd }\end{array}$ & 2531255.1 & 6196739.8 & 3902 & $\begin{array}{l}\text { Kapuni Gp, } \\
\text { Moki "A" SST" }\end{array}$ & $\begin{array}{l}\text { Plugged and } \\
\text { Abandoned }\end{array}$ \\
\hline Witiora-1 & 1037 & 1984 & $\begin{array}{c}\text { New } \\
\text { Zealand Oil } \\
\text { and Gas }\end{array}$ & 2983274.35 & 6218052.57 & 4229 & $\begin{array}{c}\text { Kapuni, } \\
\text { Pakawau Gps, } \\
\text { Moki Fm }\end{array}$ & $\begin{array}{l}\text { Plugged and } \\
\text { Abandoned }\end{array}$ \\
\hline \multicolumn{9}{|c|}{ denotes wells included in the original Seisware project from the SFM project } \\
\hline \multicolumn{9}{|c|}{ denotes well added to the Seisware project } \\
\hline
\end{tabular}

Table 2: Data collected and available over the Miocene interval of the well

\begin{tabular}{|c|c|c|c|c|c|c|}
\hline Well & PR & $\begin{array}{c}\text { Conventional } \\
\text { Core }\end{array}$ & $\begin{array}{l}\text { Sidewall } \\
\text { Core }\end{array}$ & Wireline logs & Biostrat & Comment \\
\hline Cape Farewell-1 ${ }^{2}$ & 1234 & & & $\mathrm{Y}$ & $\mathrm{Y}$ & $\begin{array}{l}\text { Mid Miocene } \\
\text { eroded }\end{array}$ \\
\hline Fresne- $1^{2}$ & 674 & & & & Y & \\
\hline Hochstetter-1 ${ }^{2,3}$ & 2524 & & & $\mathrm{Y}$ & $\mathrm{N}$ & \\
\hline Kea- $1^{1,3}$ & 1089 & & $\mathrm{Y}$ & Y & $Y$ & \\
\hline Kiwa- $1^{2,3}$ & 880 & & & $\mathrm{Y}$ & $\mathrm{Y}$ & \\
\hline Maari-1 ${ }^{1}$ & 1572 & $\mathrm{Y}$ & & $\mathrm{Y}$ & $\mathrm{N}$ & \\
\hline Maui- $1^{1,3}$ & 540 & & $\mathrm{Y}$ & $\mathrm{Y}$ & $\mathrm{Y}$ & \\
\hline Maui-2 & 541 & & $\mathrm{Y}$ & $\mathrm{Y}$ & $\mathrm{Y}$ & \\
\hline Maui-3 $^{1.3}$ & 542 & & $\mathrm{Y}$ & $Y$ & Y & \\
\hline Maui- $4^{1,3}$ & 543 & & $\mathrm{Y}$ & $\mathrm{Y}$ & $\mathrm{Y}$ & \\
\hline Maui- $5^{2}$ & 1182 & & 6 shot all lost & Y & $\mathrm{N}$ & \\
\hline Maui-7 ${ }^{1}$ & 1218 & & & $\mathrm{Y}$ & $\mathrm{N}$ & \\
\hline Maui-B6 & 2584 & & & & $\mathrm{~N}$ & \\
\hline Maui-B7 & 2594 & & & $\mathrm{Y}$ & $\mathrm{N}$ & \\
\hline
\end{tabular}




\begin{tabular}{|c|c|c|c|c|c|c|}
\hline Well & PR & $\begin{array}{c}\text { Conventional } \\
\text { Core }\end{array}$ & $\begin{array}{c}\text { Sidewall } \\
\text { Core }\end{array}$ & Wireline logs & Biostrat & Comment \\
\hline MB-P(8) ${ }^{1}$ & & & & & $\mathrm{~N}$ & \\
\hline$M B-Z(11)^{2}$ & 1911 & $\mathrm{Y}$ & $\mathrm{Y}$ & Y & & \\
\hline Maui South-1 ${ }^{2}$ & 2254 & $\mathrm{Y}$ & $\mathrm{Y}$ & $\mathrm{Y}$ & & \\
\hline Moki-1 $1^{1,3}$ & 987 & & $\mathrm{Y}$ & Y & Y & \\
\hline Moki-2A $A^{1,3}$ & 1100 & $\begin{array}{l}\text { M2A sand and } \\
\text { mudstone below }\end{array}$ & $Y$ & $Y$ & $\mathrm{Y}$ & \\
\hline Motueka-1 ${ }^{2,3}$ & 1685 & & $Y$ & $Y$ & $Y$ & \\
\hline $\begin{array}{c}\text { North Tasman- } \\
1^{1,3}\end{array}$ & 736 & & & $\mathrm{Y}$ & $\mathrm{Y}$ & \\
\hline Pukeko-1 $1^{2.3}$ & 2928 & & & $\mathrm{Y}$ & $\mathrm{Y}$ & \\
\hline Rahi-1 ${ }^{2}$ & 2277 & & & $\mathrm{Y}$ & & \\
\hline Surville-1 ${ }^{2}$ & 677 & & & $\mathrm{Y}$ & $\mathrm{Y}$ & Sc- $Q$ eroded \\
\hline Tahi-1 ${ }^{1}$ & 1030 & & & & & $\begin{array}{l}\text { Mid Miocene } \\
\text { eroded }\end{array}$ \\
\hline Tasman- $1^{2,3}$ & 512 & & $\mathrm{Y}$ & $\mathrm{Y}$ & $Y$ & \\
\hline Te Whatu-2 $2^{1,3}$ & 1345 & & & $\mathrm{Y}$ & $\mathrm{Y}$ & \\
\hline Tui-1 ${ }^{2}$ & 2784 & & & $\mathrm{Y}$ & $\mathrm{Y}$ & \\
\hline Witiora-1 & 1037 & & $\mathrm{Y}$ & $\mathrm{Y}$ & $Y$ & \\
\hline \multicolumn{7}{|c|}{ denotes wells included in the original Seisware project from the SFM project } \\
\hline \multicolumn{7}{|c|}{ denotes well added to the Seisware project } \\
\hline \multicolumn{7}{|c|}{${ }^{3}$ denotes well with well sheet made for wireline log analysis } \\
\hline secondary petro & $n$ ext & ation target & & & & \\
\hline
\end{tabular}

\section{b) Velocity curves}

Velocity surveys were conducted in most wells throughout the study area. However, in the wells that did conduct a velocity survey some did not publish the time-depth data or was of poor and unreliable quality. In these cases, and where velocity surveys were not conducted, velocity data from neighbouring wells were substituted. Table 3 summarises the velocity surveys used.

Table 3: Velocity curve summary (VSP $=$ vertical seismic profile)

\begin{tabular}{lll}
\hline \multicolumn{1}{c}{ Well } & \multicolumn{1}{c}{ Comment } & \multicolumn{1}{c}{ Solution } \\
\hline Cape Farewell-1 $^{2}$ & VSP survey PR674 & \\
\hline Fresne-1 $^{2}$ & PR674 \\
\hline Hochstetter-1 & $\begin{array}{l}\text { No mention of velocity survey } \\
\text { conducted in PR2524 }\end{array}$ & Substituted Kiwa-1 time-depth curve \\
\hline Kea-1 ${ }^{1,3}$ & $\begin{array}{l}\text { From SFM project, GNS } \\
\text { wellsheet }\end{array}$ \\
\hline Kiwa-1 $\mathbf{1}^{2,3}$ & Checkshot survey PR880 \\
\hline
\end{tabular}




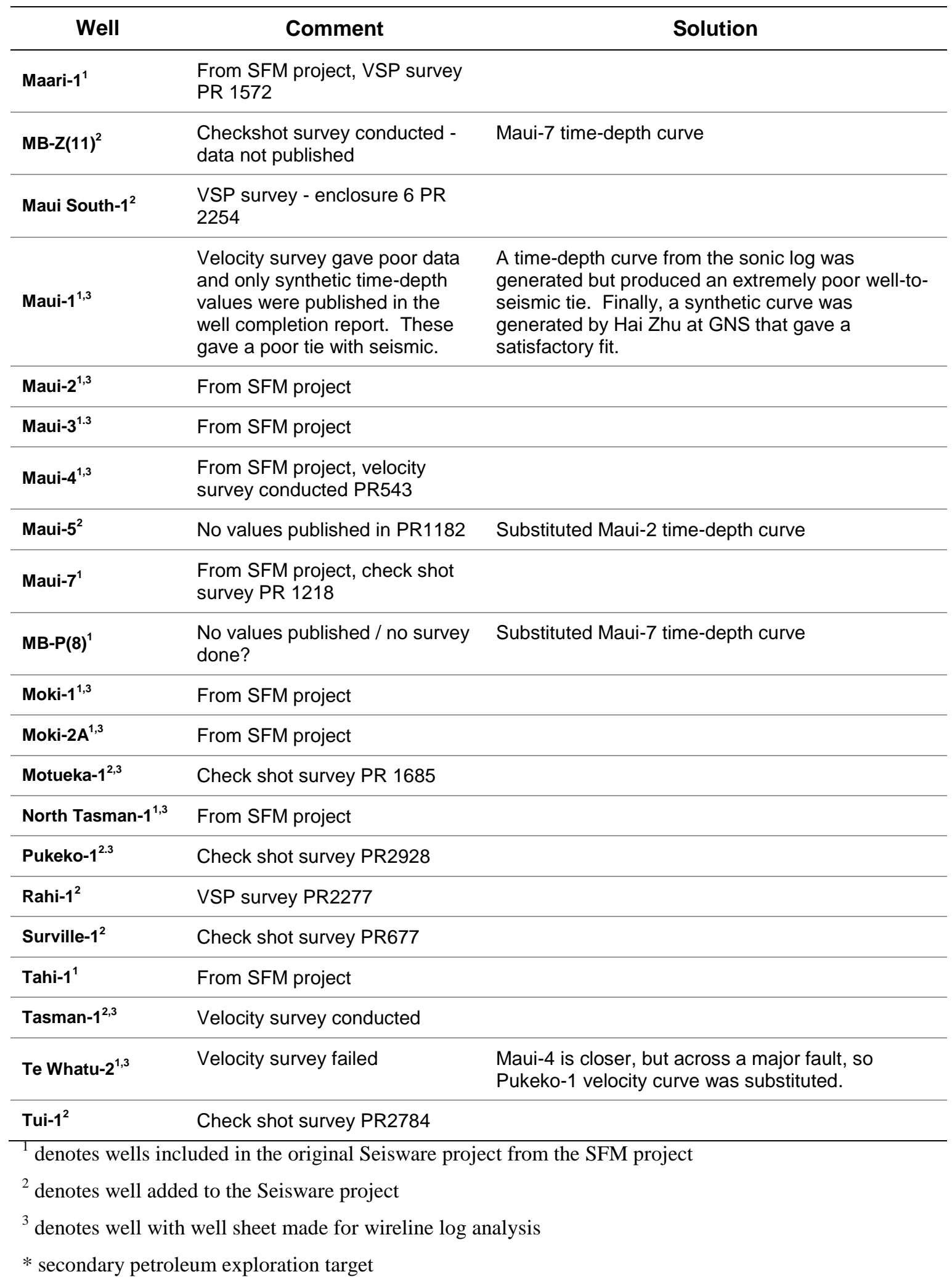


c) Revised formation tops

Table 4: Revised formation tops

\begin{tabular}{|c|c|c|c|c|c|c|c|c|c|c|c|c|c|}
\hline & 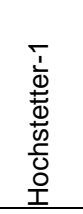 & 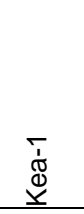 & $\sum_{\substack{\bar{d}\\
}}^{\bar{d}}$ & $\begin{array}{l}\frac{\bar{I}}{\bar{T}} \\
\frac{\pi}{\Sigma}\end{array}$ & $\begin{array}{l}\stackrel{N}{\frac{N}{3}} \\
\stackrel{\pi}{\Sigma}\end{array}$ & $\begin{array}{l}m \\
\frac{m}{5} \\
\frac{\pi}{2}\end{array}$ & $\begin{array}{l}\stackrel{+}{+} \\
\stackrel{+}{5} \\
\stackrel{\mathbb{\pi}}{\Sigma}\end{array}$ & $\begin{array}{l}\frac{\bar{T}}{\bar{z}} \\
\frac{0}{\Sigma}\end{array}$ & 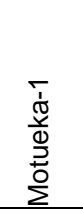 & 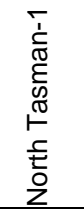 & 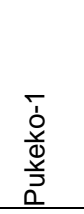 & 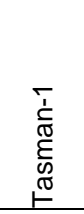 & $\begin{array}{l}N \\
\stackrel{N}{1} \\
\stackrel{N}{N} \\
\stackrel{N}{3} \\
0 \\
\end{array}$ \\
\hline \multicolumn{14}{|c|}{ Top Manganui } \\
\hline Formation & 1550 & 1047 & 1550 & 605 & 715 & 750 & 422 & 567 & & 292 & 2550 & 300 & 425 \\
\hline \multicolumn{14}{|l|}{ Top SI/Sw } \\
\hline Sandstone & & & & 1825 & 1635 & 1832 & 716 & 980 & 385 & 645 & & & \\
\hline \multicolumn{14}{|l|}{ Base SI/Sw } \\
\hline Sandstone & & & & 1994 & 1687 & 1914 & 773 & 1010 & 578 & 691 & & & \\
\hline \multicolumn{14}{|l|}{ Top Moki } \\
\hline Formation & & 2208 & 2818 & 2128 & 2096 & 2133 & 1328 & 1304 & 815 & 1283 & 2960 & 799 & 2635 \\
\hline \multicolumn{14}{|l|}{ Base Moki } \\
\hline Formation & & 2574 & 2888 & 2333 & 2413 & 2367 & 1707 & 1834 & 855 & 1567 & 3100 & 1009 & 2925 \\
\hline \multicolumn{14}{|c|}{ Base Manganui } \\
\hline Formation & 2711 & 2805 & 2950 & 2535 & 2556 & 2523 & 1890 & 2038 & 1400 & 1821 & 3200 & 1210 & 3123 \\
\hline
\end{tabular}




\section{Appendix E Well sheets}

Well sheets for the 13 key wells in the wireline log study are presented at a 1:5000 scale in alphabetical order with wireline logs, sidewall core depths, revised stratigraphy and current biostratigraphy information for the Miocene interval. These wells are Hochstetter-1, Kea1, Kiwa-1, Maui-1, Maui-2, Maui-3, Maui-4, Moki-1, Motueka-1, North Tasman-1, Pukeko-1, Tasman-1 and Te Whatu-2 (Figure 1). Data used for the construction of these wellsheets was compiled from open file petroleum and biostratigraphic reports. A key for the well sheets is included overleaf. All coordinates are in New Zealand Geodetic Datum 1949.

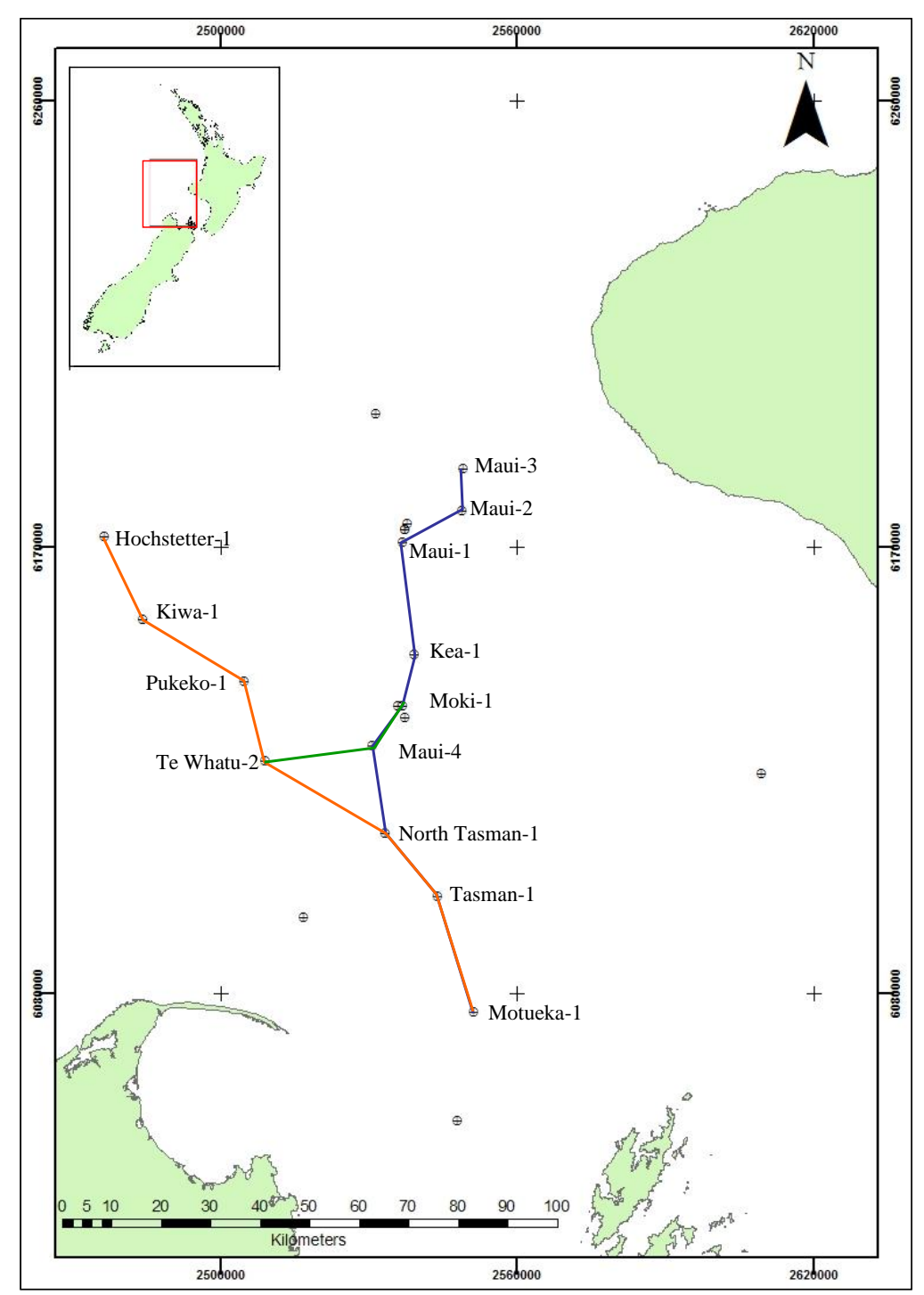

Figure 0.1: Location map of wells in this Appendix. 


\section{Key for well sheets}

Track 1 Depth $\mathrm{m}$ below drill floor

Track 2 Casing points

Track 3 Caliper (red), gamma ray (black)

Track 4 Resistivity logs

Track 5 Sonic (blue), spontaneous potential (green)

Track 6 Neutron (blue), density (red)

Track 7 Cores and sidewall cores

Track 8 Interpreted lithology

Track 9 Revised formations

Track 10 Palaeontology sample depth

Track 11 New Zealand stages

Track 12 Epoch

Track 13 Palaeoenvironment

Track 14 Key biomarkers 


\begin{tabular}{|c|c|c|c|}
\hline \multicolumn{4}{|c|}{ HOCHSTETTER-1 } \\
\hline Latitude (NZGD 1949): & $39^{\circ} 39^{\prime} 39.756^{\prime \prime} \mathrm{S}$ & Longitude (NZGD 1949): & $172^{\circ} 36^{\prime} 22.951^{\prime \prime} \mathrm{E}$ \\
\hline NZMG: & $2476240.80 \mathrm{E}$ & & $6171779.17 \mathrm{~N}$ \\
\hline Spud date: & 9 February 2002 & Operator: & New Zealand Oil and Gas \\
\hline Petroleum Report: & 2524 & Deviation: & Near vertical \\
\hline Water depth: & $217 \mathrm{~m}$ & DF elevation: & $22 \mathrm{~m}$ AMSL \\
\hline Total depth: & 3298 m AHBDF & Status: & Plugged and Abandoned \\
\hline Scale: & $1: 5000$ & Edited by: & Sarah Grain \\
\hline \multicolumn{4}{|l|}{ Biostratigraphy: } \\
\hline \multicolumn{4}{|l|}{ Notes: } \\
\hline \multicolumn{4}{|c|}{$\begin{array}{l}\text { Formations were revised as part of this study from the original presented in the Petroleum Report with } \\
\text { corroboration from lithology (from wireline log and cuttings), biostratigraphy data, wireline and seismic } \\
\text { correlation. }\end{array}$} \\
\hline
\end{tabular}

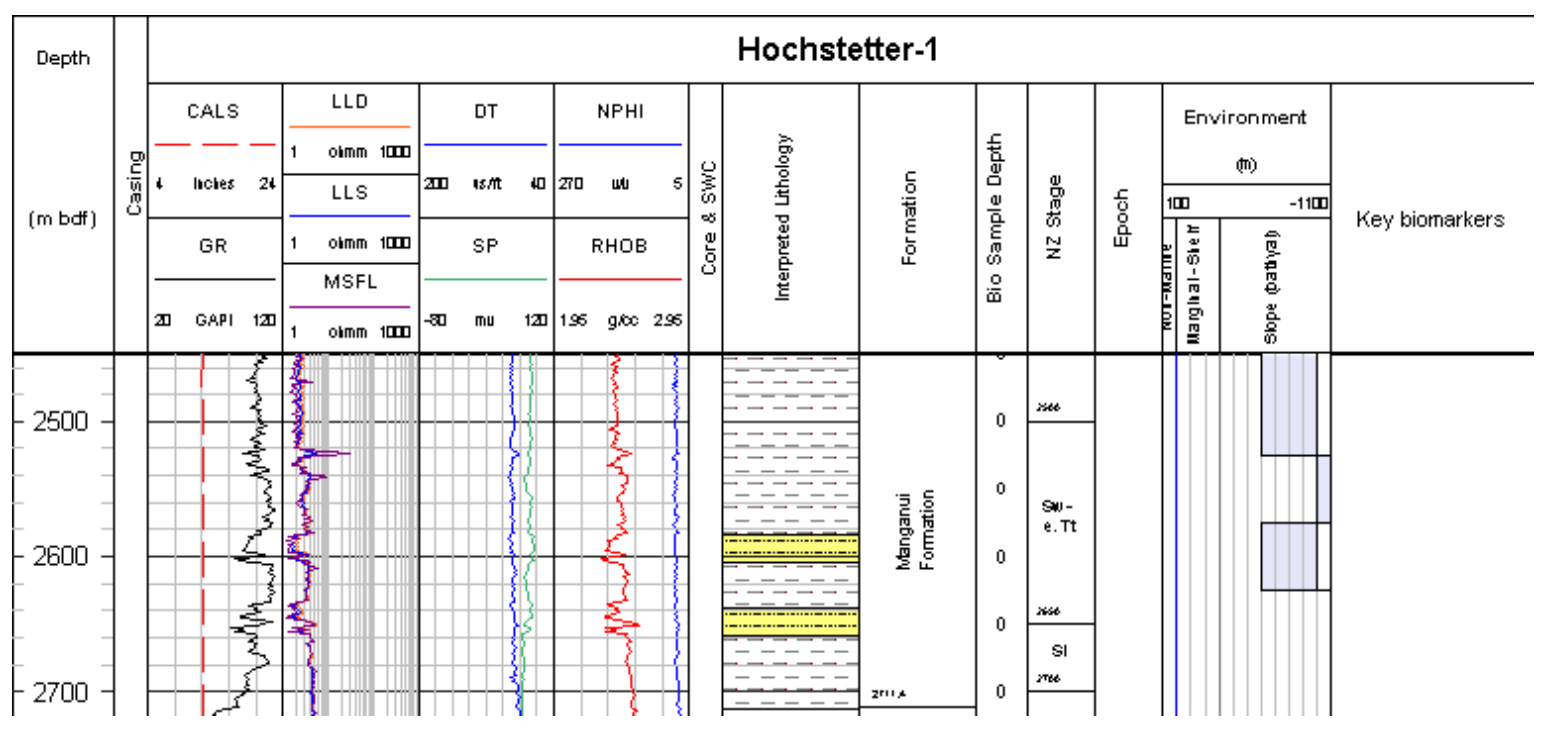




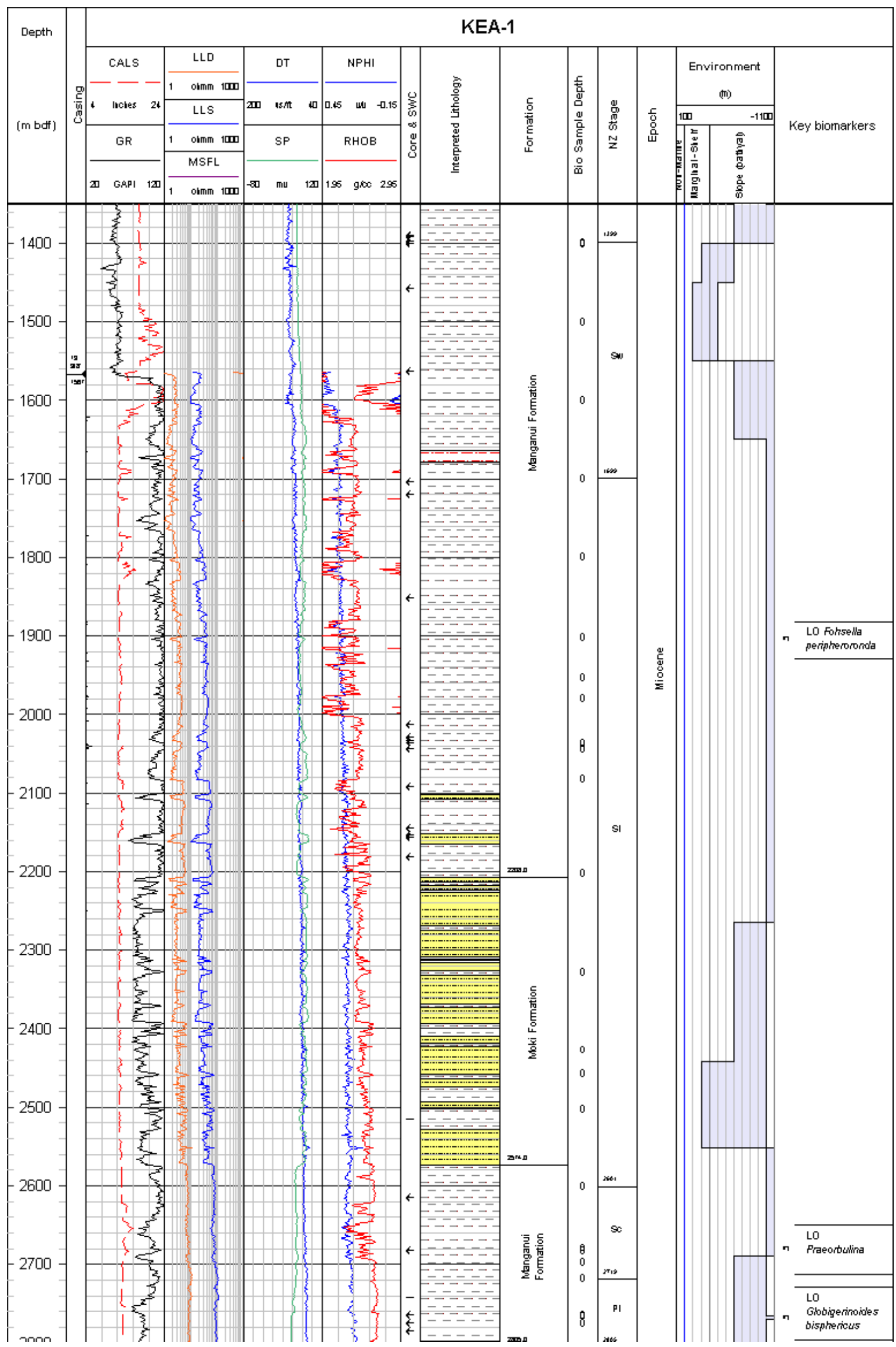




\begin{tabular}{|c|c|c|c|}
\hline \multicolumn{4}{|c|}{ KIWA-1 } \\
\hline Latitude: & $39^{\circ} 48^{\prime} 39.35^{\prime \prime} \mathrm{S}$ & Longitude: & $172^{\circ} 41^{\prime} 53.43^{\prime \prime} \mathrm{E}$ \\
\hline NZMG: & $6155161 \mathrm{mN}$ & & $2484171 \mathrm{mE}$ \\
\hline Spud date: & 28 April 1981 & Operator: & Shell BP and Todd Oil Services \\
\hline Petroleum Report: & 880 & Deviation: & Near vertical \\
\hline Water depth: & $173.7 \mathrm{~m}$ & DF elevation: & $11.3 \mathrm{~m}$ AMSL \\
\hline Total depth: & $3858 \mathrm{~m}$ BDF & Status: & Plugged and Abandoned \\
\hline Scale: & $1: 5000$ & Edited by: & Sarah Grain \\
\hline \multicolumn{4}{|l|}{ Biostratigraphy: } \\
\hline \multicolumn{4}{|l|}{ Notes: } \\
\hline \multicolumn{4}{|c|}{$\begin{array}{l}\text { Formations were revised as part of this study from the original presented in the Petroleum Report with } \\
\text { corroboration from lithology (from wireline log and cuttings), biostratigraphy data, wireline and seismic } \\
\text { correlation. }\end{array}$} \\
\hline
\end{tabular}




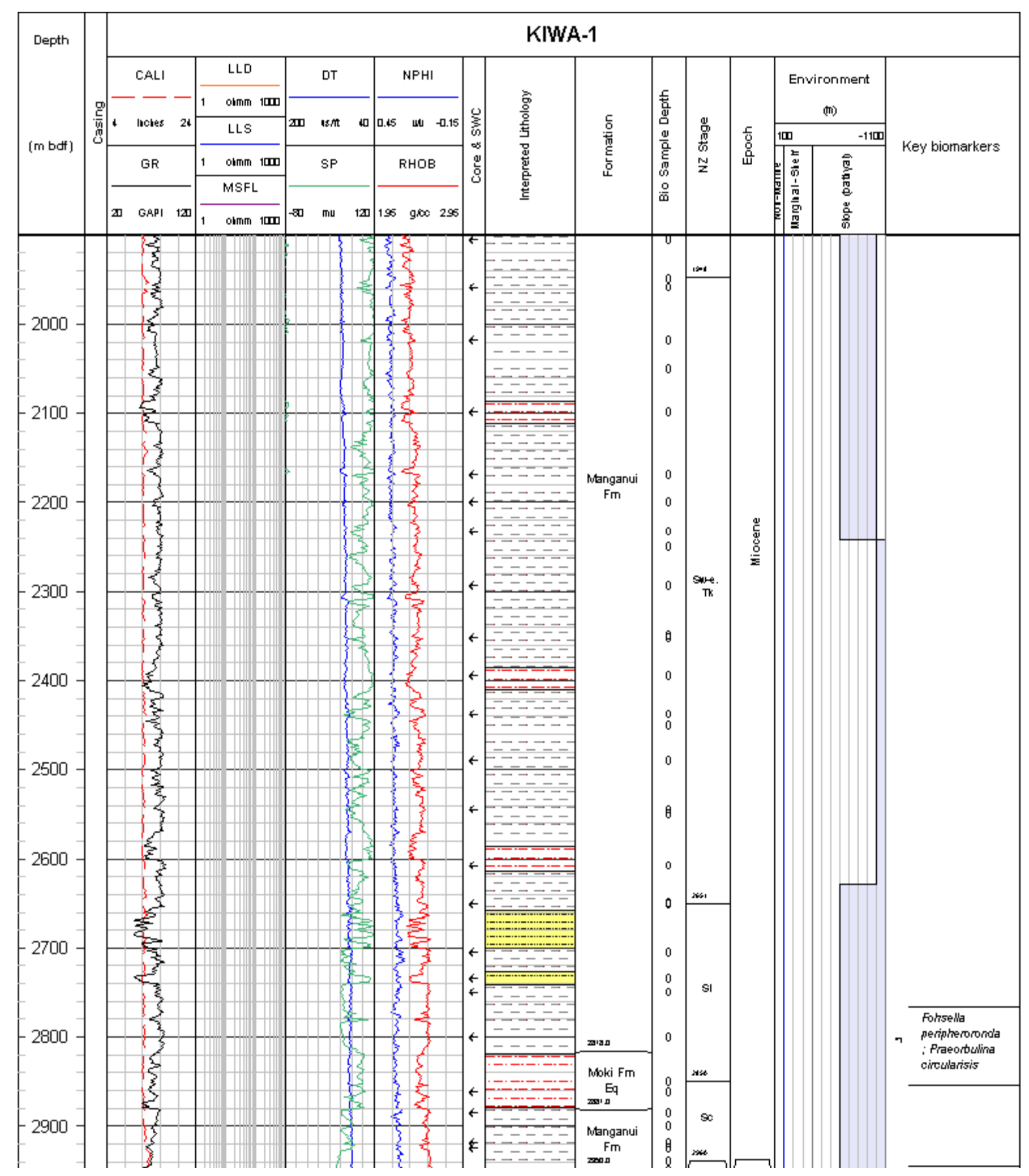




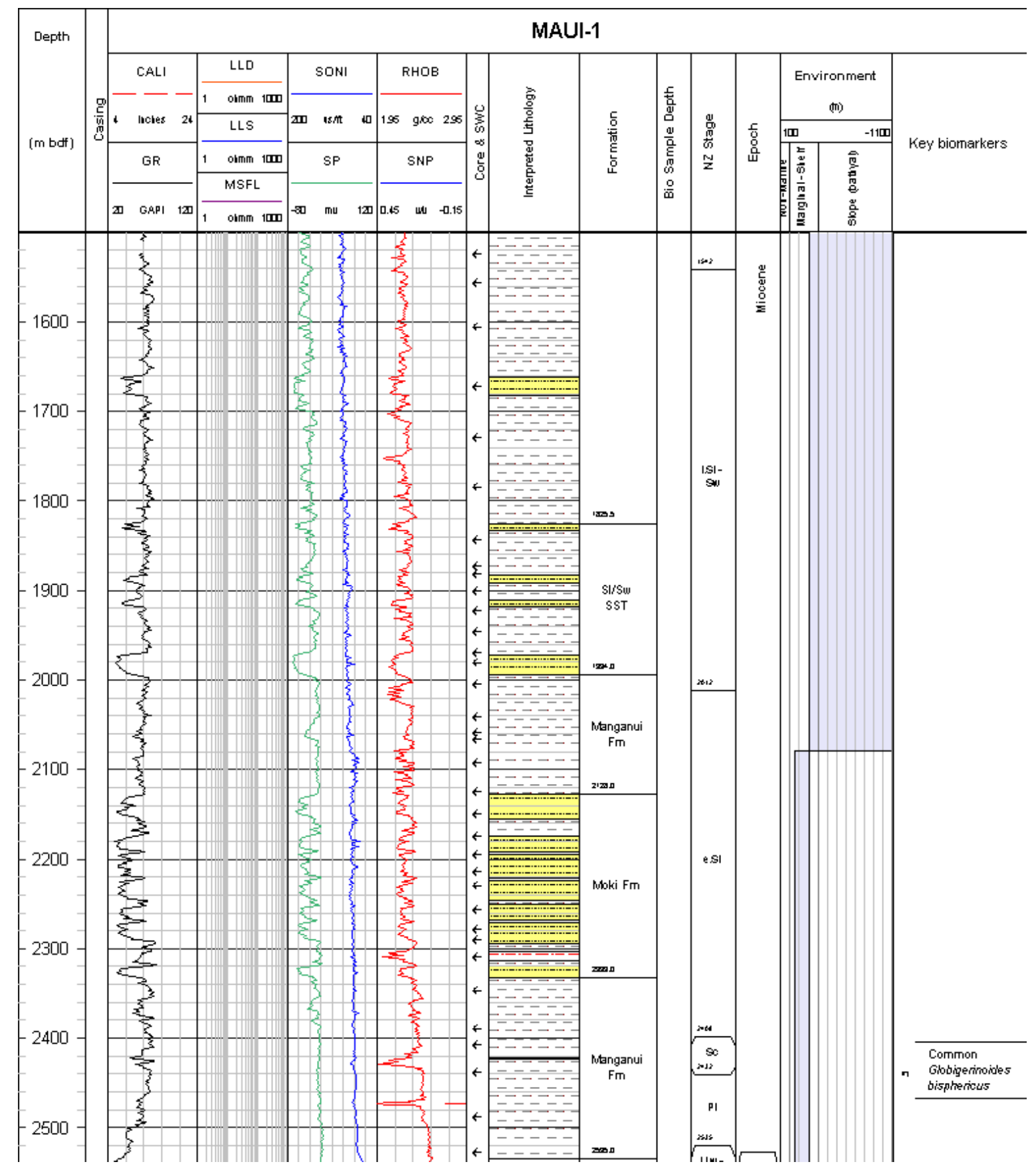




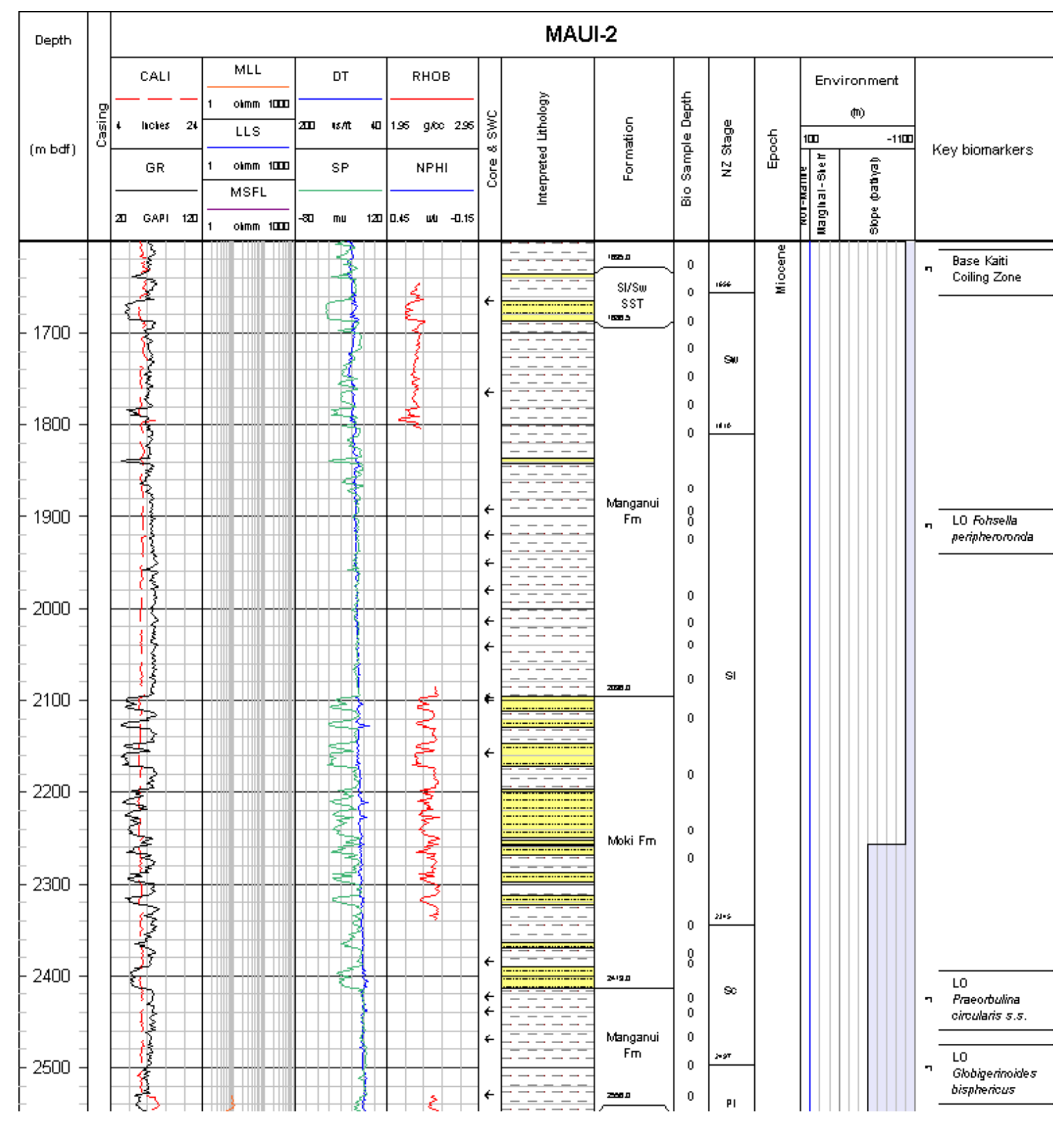




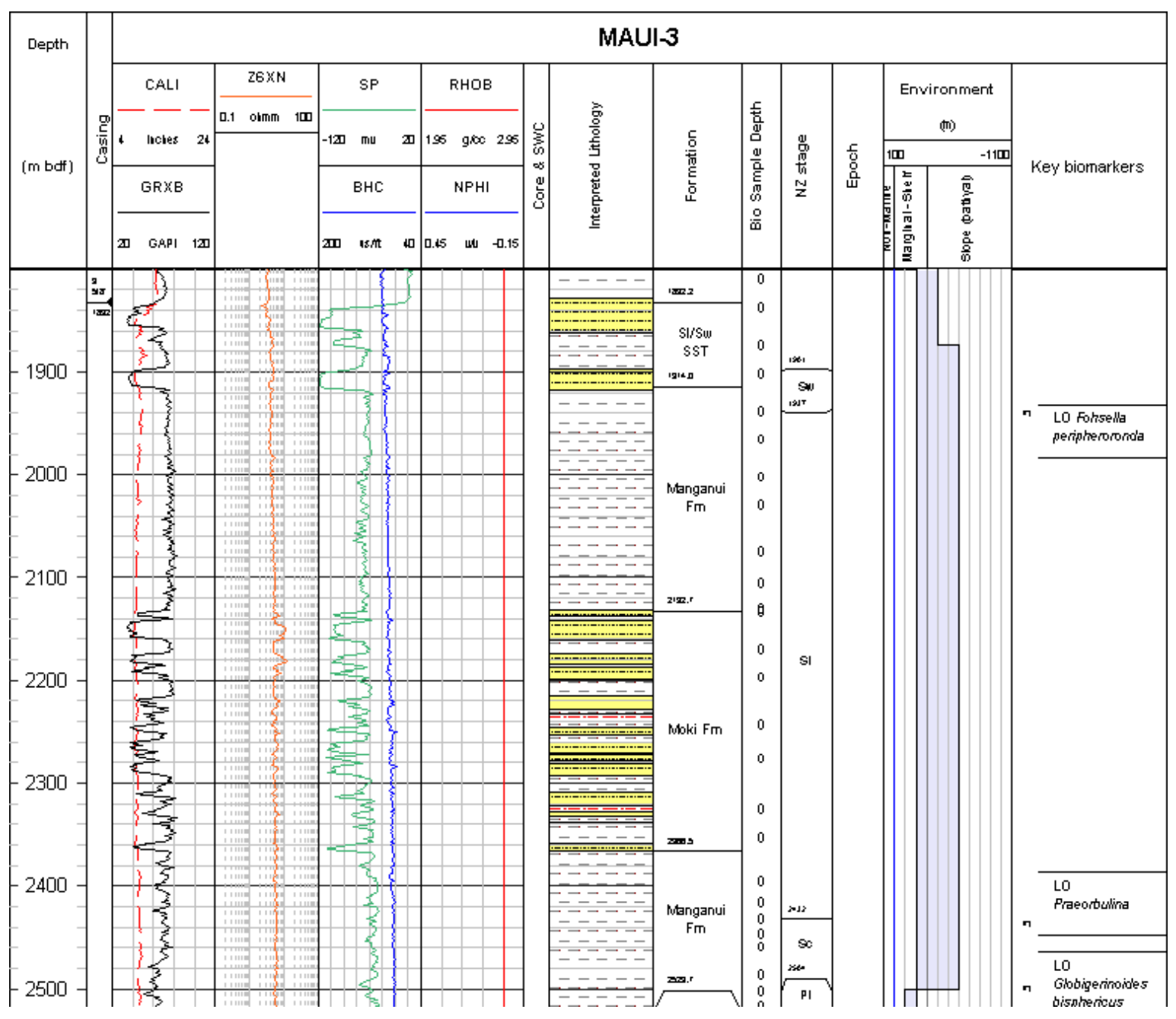




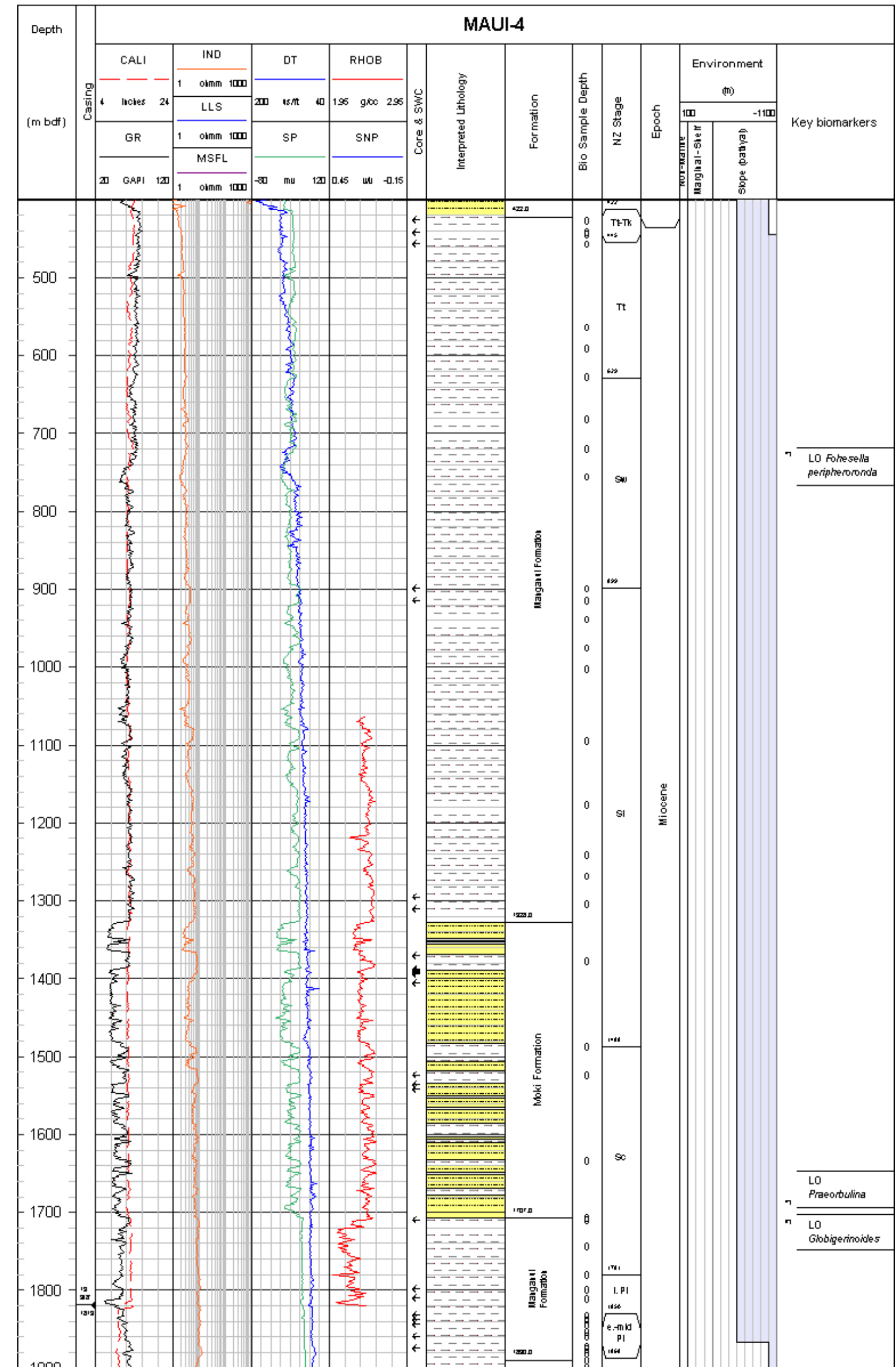




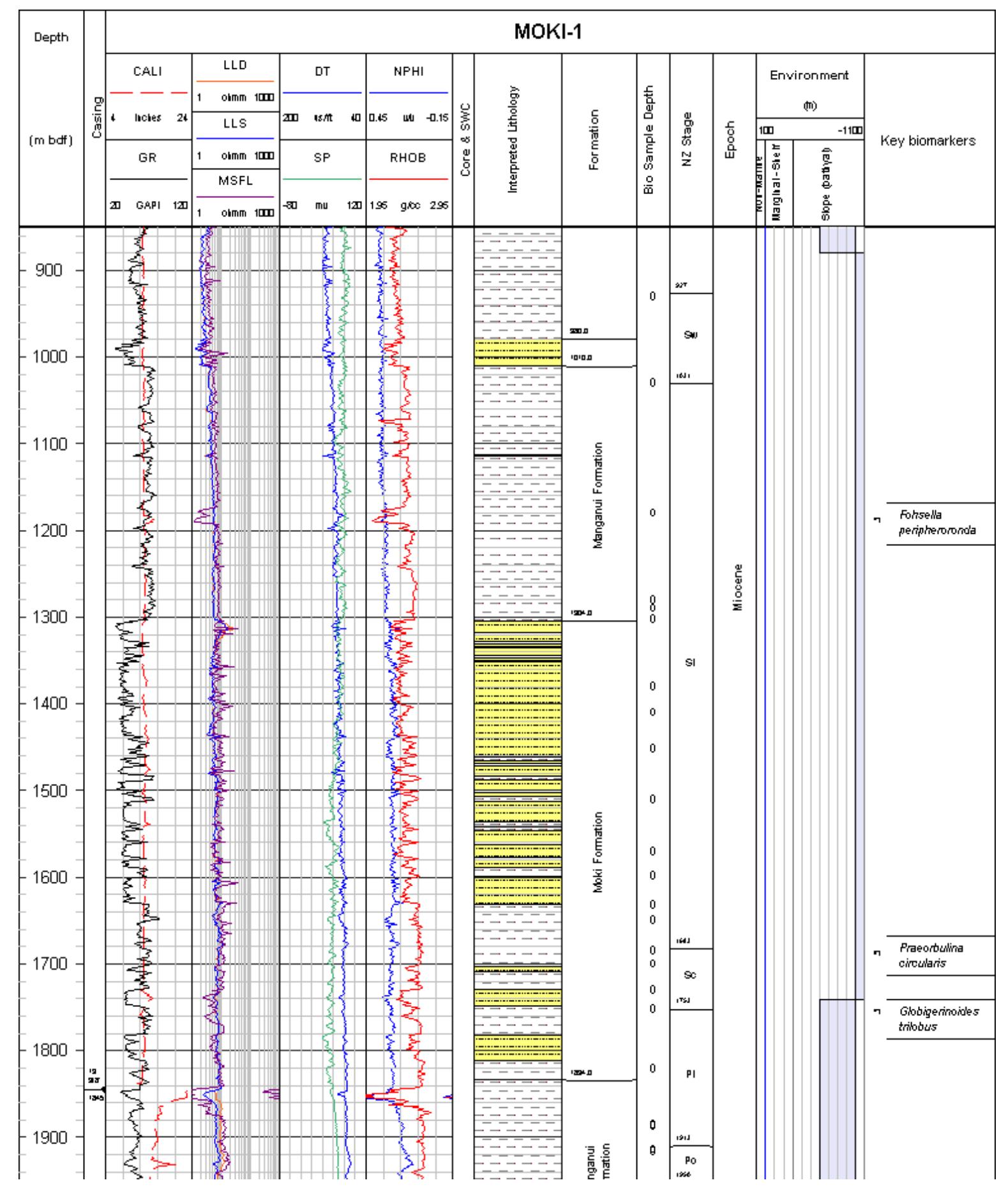




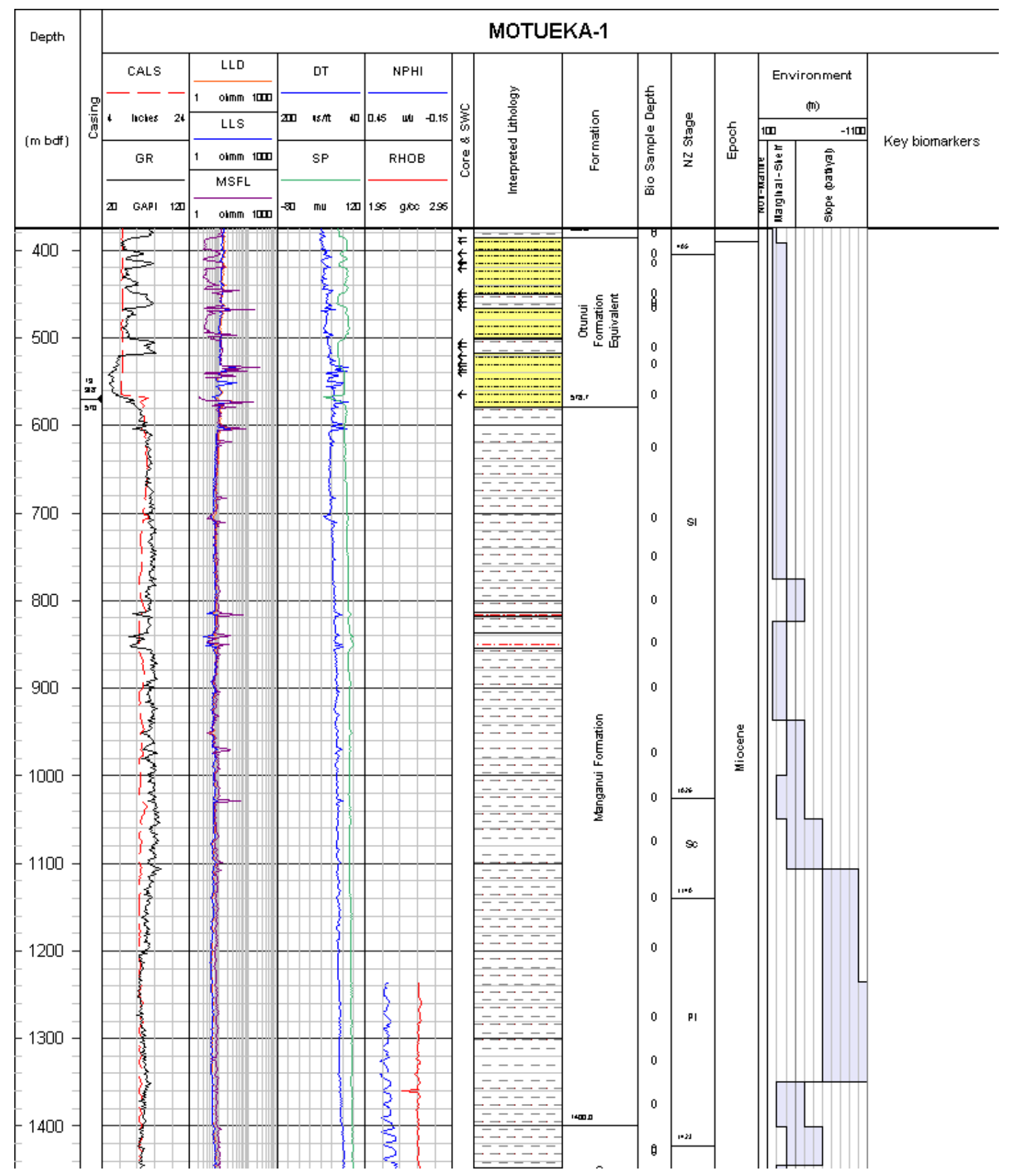




\section{NORTH TASMAN-1}

Latitude:

NZMG:

Spud date:

26 October 1978

Petroleum Report:

736

Water depth:

$86 \mathrm{~m}$

2727 m BDF

$1: 5000$

Scale:

Biostratigraphy:

Hayward, B.W., Raine, J.I. 1978: Biostratigraphy of North Tasman-1 offshore well. NZGS Report PAL 30 Morgans, H.E.G., Wilson, G.J., Mildenhall, D.C., Strong, C.P. 1991: Review of the Lower Section of the Tasman-1 and North Tasman-1 Offshore well, North Tasman Bay/South Taranaki Bight Area. DSIR Geology \& Geophysics Contract Report 1999/11

Crundwell, M. 1994: Review of foraminiferal slides from Miocene intervals in Tasman, North Tasman, Maui-4 and Kea, petroleum exploration wells. IGNS Client Report 53453.A

Notes:

Formations were revised as part of this study from the original presented in the Petroleum Report with corroboration from lithology (from wireline log and cuttings), biostratigraphy data, wireline and seismic correlation. 


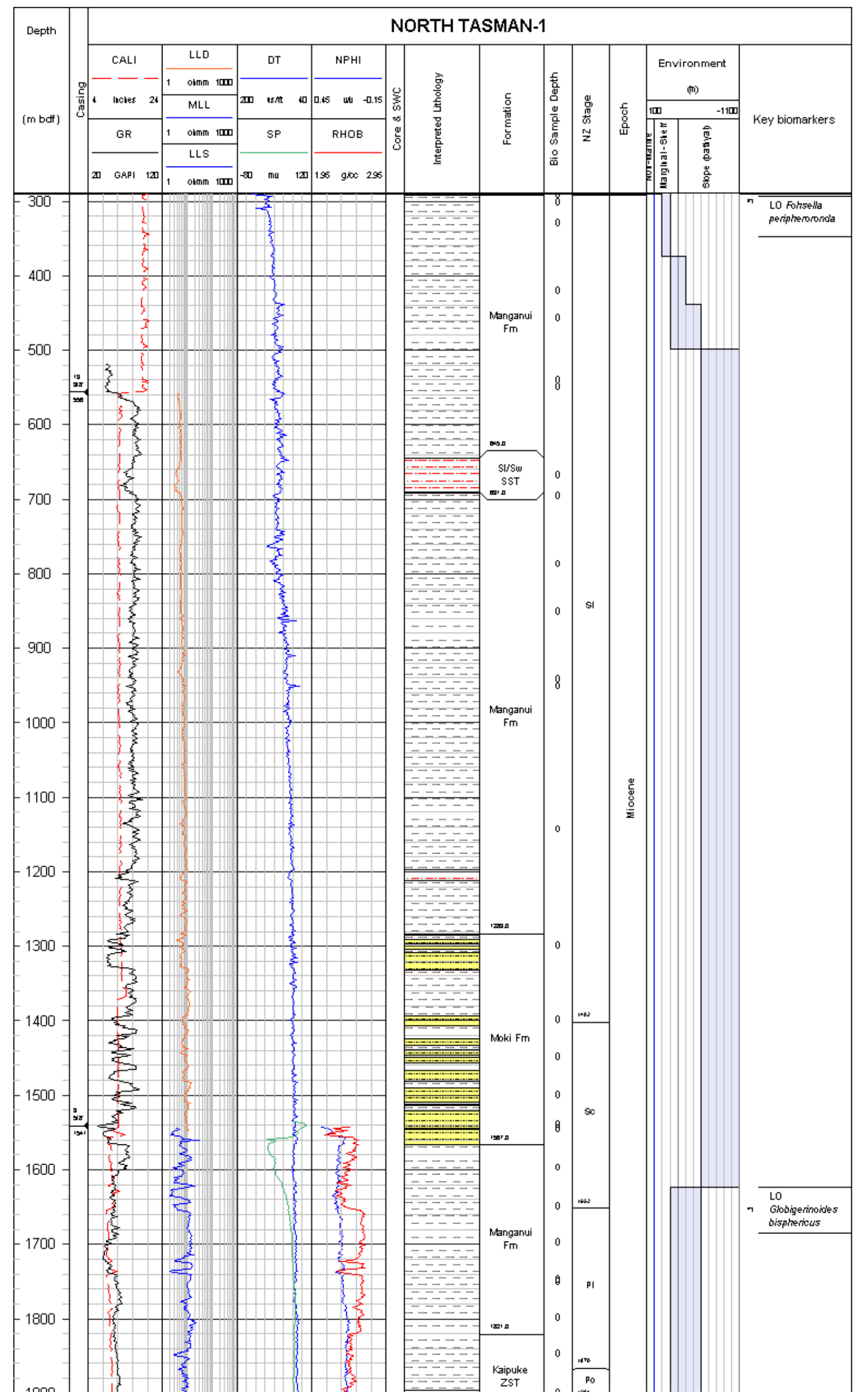




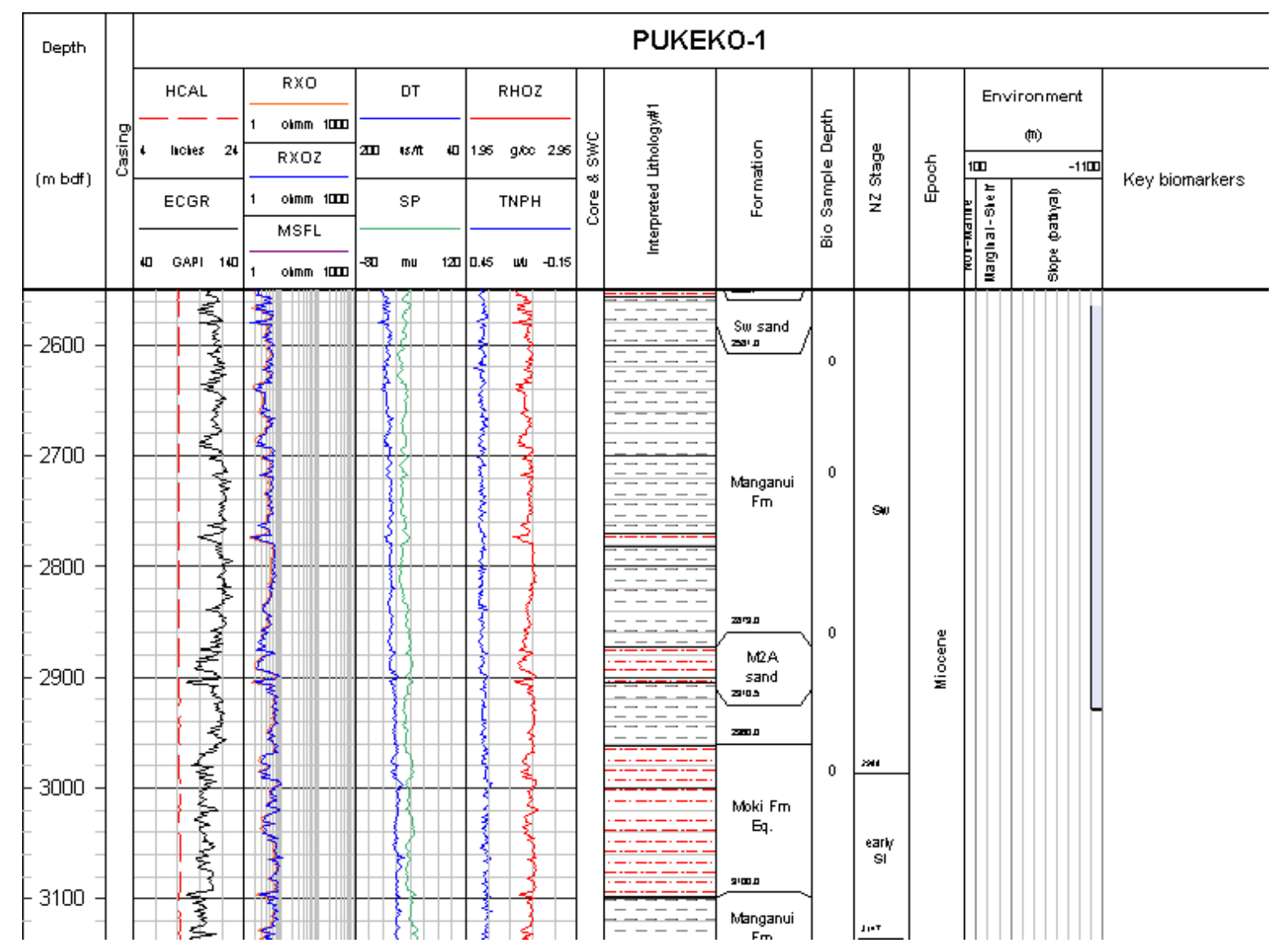


TASMAN-1

Latitude: $\quad 40^{\circ} 18^{\prime} 53.478^{\prime \prime} \mathrm{S} \quad$ Longitude: $\quad 173^{\circ} 23^{\prime} 46.913^{\prime \prime} \mathrm{E}$

NZMG:

Spud date:

7 March 1970

Operator:

New Zealand Aquitaine Petroleum Ltd

Petroleum Report: $\quad 512$

Deviation: Near vertical

Water depth:

244 feet $(74.4 \mathrm{~m})$

DF elevation: 122 feet $(37.2 \mathrm{~m})$

Total depth:

5345 feet (1629.2 m) BDF

Status:

Plugged and Abandoned

Scale:

Edited by:

Sarah Grain

Biostratigraphy:

Schroeder, A.G. 1970: The micropalaeontology of Tasman-1 offshore well. In: New Zealand Aquitaine Petroleum Ltd. Tasman-1 well completion report. Unpublished petroleum report 512. Ministry of Economic Development.

Crundwell, M. 1994. Review of foraminiferal slides from Miocene intervals in Tasman, North Tasman, Maui-4 and Kea, petroleum exploration wells. GNS Client Report 53453.A

Notes:

Formations were revised as part of this study from the original presented in the Petroleum Report with corroboration from lithology (from wireline log and cuttings), biostratigraphy data, wireline and seismic correlation. 


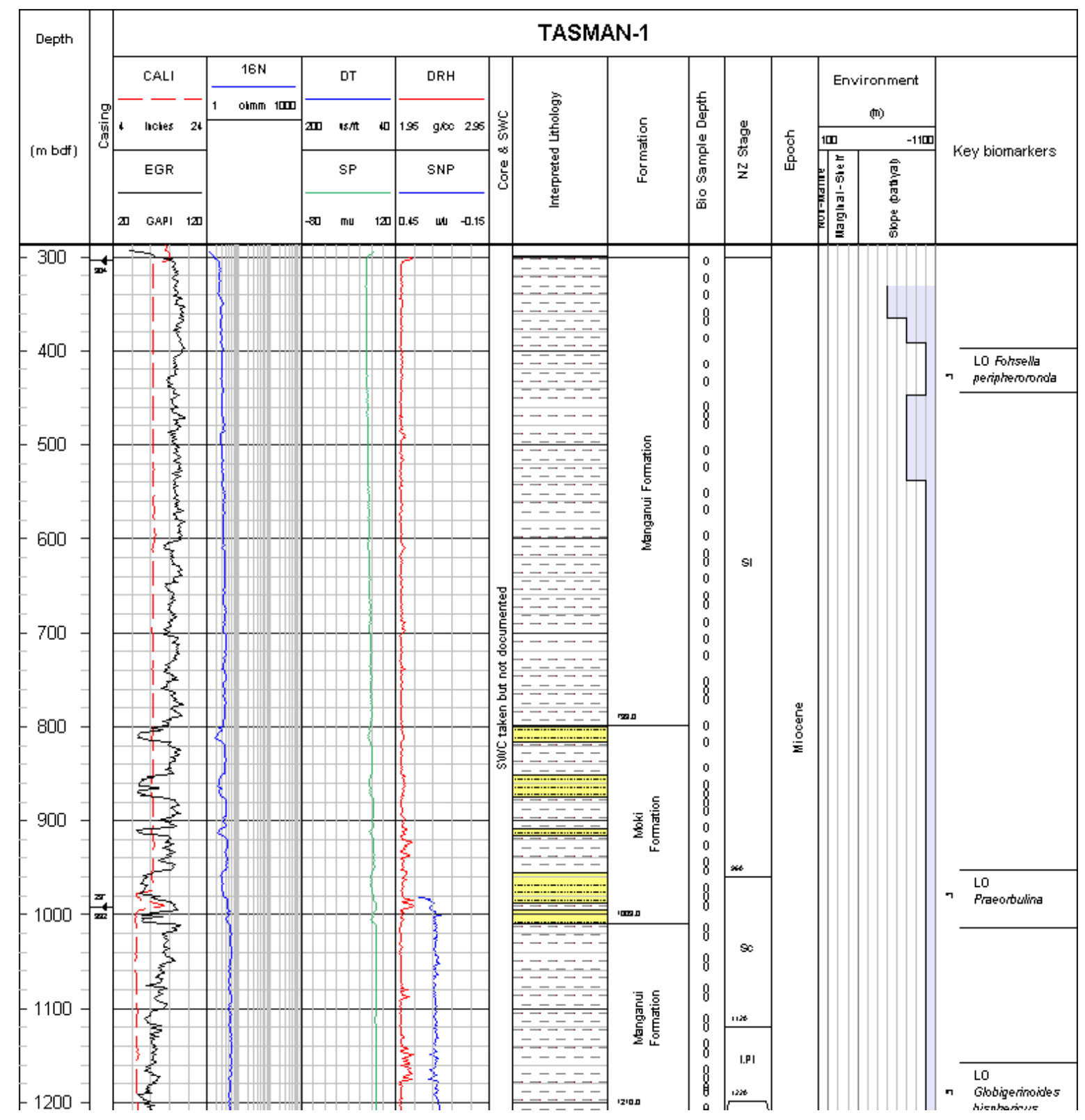




\begin{tabular}{|c|c|c|c|}
\hline \multicolumn{4}{|c|}{ TE WHATU-2 } \\
\hline Latitude: & $40^{\circ} 04^{\prime} 06.312^{\prime \prime} \mathrm{S}$ & Longitude: & $172^{\circ} 59^{\prime} 14.299^{\prime \prime} \mathrm{E}$ \\
\hline NZMG: & $6126602.53 \mathrm{mN}$ & & $2508929.21 \mathrm{mE}$ \\
\hline Spud date: & 11 October 1987 & Operator: & Petrocorp Exploration Limited \\
\hline Petroleum Report: & 1345 & Deviation: & Near vertical \\
\hline Water depth: & $114 \mathrm{~m}$ & DF elevation: & $27 \mathrm{~m}$ \\
\hline Total depth: & $3542 \mathrm{~m}$ & Status: & Plugged and Abandoned \\
\hline Scale: & $1: 5000$ & Edited by: & Sarah Grain \\
\hline \multicolumn{4}{|l|}{ Biostratigraphy: } \\
\hline \multicolumn{4}{|c|}{$\begin{array}{l}\text { Strong, C.P., Mildenhall, D.C., Scott, G.H. 1988: Biostratigraphy of Te Whatu } 1 \& 2 \text { offshore petroleum } \\
\text { exploration wells, southwestern Taranaki Basin. NZGS Report PAL 128. (also IGNS Science Report 93/23) }\end{array}$} \\
\hline \multicolumn{4}{|c|}{ Crouch, E., Crundwell, M.P., Strong, C.P., Cook, R.A. 1994: Taranaki biostratigraphic review: Phase 2. IGNS } \\
\hline \multicolumn{4}{|c|}{ Client Report 53450A } \\
\hline \multirow{2}{*}{\multicolumn{4}{|c|}{$\begin{array}{l}\text { Crundwell, M.P. 1995: Late Miocene and Pliocene biostratigraphic well review offshore Taranaki. GNS Client } \\
\text { Report 53453A-10 }\end{array}$}} \\
\hline & & & \\
\hline \multicolumn{4}{|l|}{ Notes: } \\
\hline \multicolumn{4}{|c|}{$\begin{array}{l}\text { Formations were revised as part of this study from the original presented in the Petroleum Report with } \\
\text { corroboration from lithology (from wireline log and cuttings), biostratigraphy data, wireline and seismic } \\
\text { correlation. }\end{array}$} \\
\hline
\end{tabular}




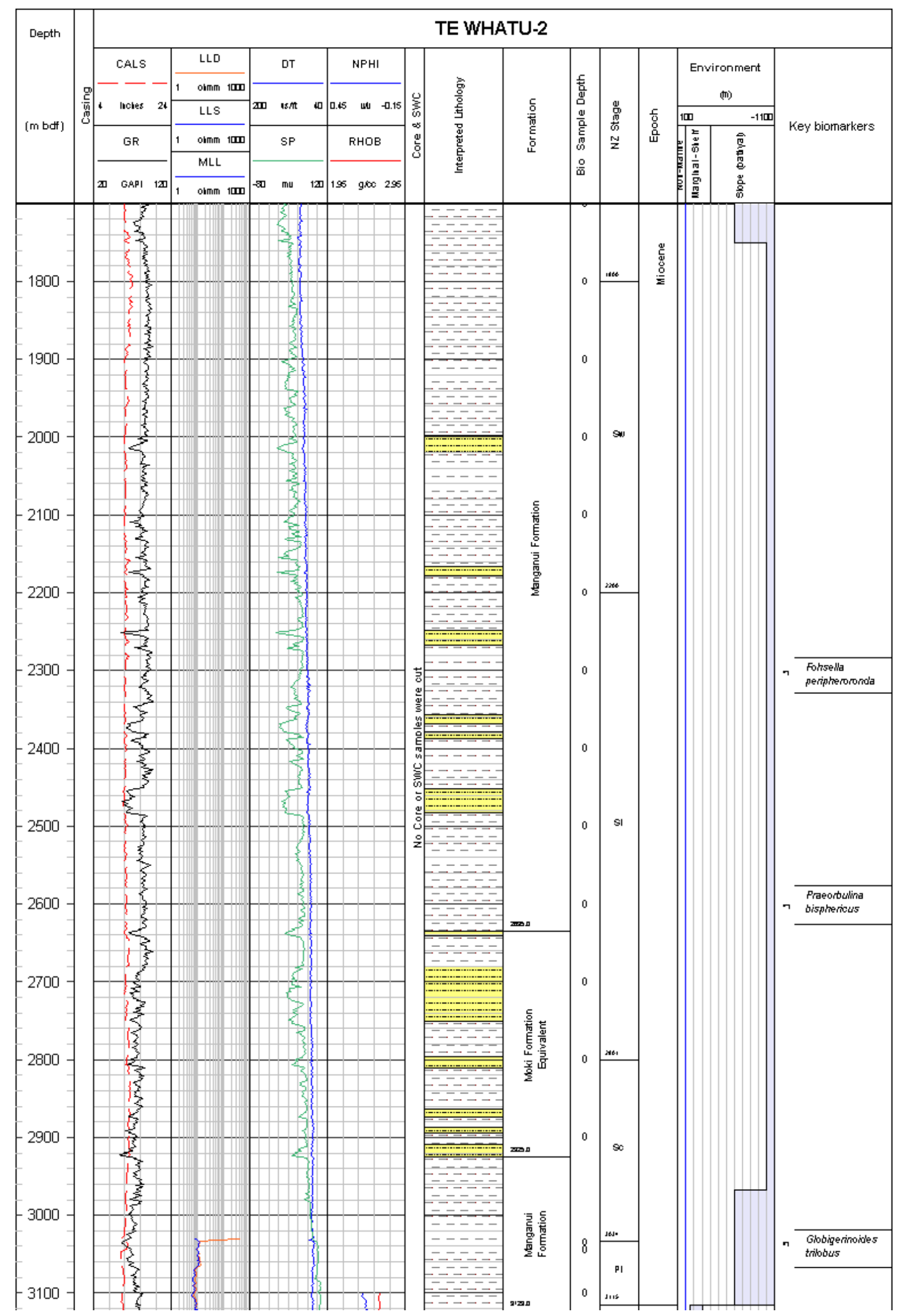




\section{Appendix F Core descriptions and photographs}

This appendix provides core descriptions and photographs for each of the cores described in this study. Core intervals described and photographed were selected as typical Moki Formation facies identified from core photographs in well completion reports. These core intervals are:

Maari-1 $\quad 1306-1309 \mathrm{~m}$

$1323-1329 \mathrm{~m}$

Maui South-1 2304-2307 m

Moki-2A $\quad 1262-1263.13 \mathrm{~m}^{*}$

$1264.98-1265.81 \mathrm{~m}^{*}$

MB-(Z) $11 \quad 2132.9-2133.8 \mathrm{~m}$

All depths referred to are Measured Depths (MD).

Detailed sedimentological descriptions and photographs were done by Sarah Grain, Matthew Stevens, Cliff Atkins (Geologists).

* Core was recovered in the M2A sandstone and Manganui Formation above the Moki Formation

\section{Key for core description sheets}

\begin{tabular}{|c|c|c|c|}
\hline & Sandstone & $\Leftrightarrow$ & Contourted bedding \\
\hline & Mudstone & & Load casts \\
\hline$\not<$ & Massive & $\oplus$ & Bioturbated \\
\hline - & Laminated / bedded & & \\
\hline & Non-planar & & Fractured fossils \\
\hline 2 & laminations/bedding & & Mud clasts \\
\hline 1 & Cross bedded & & \\
\hline$\curvearrowleft$ & Convoluted bedded & & Concretion \\
\hline
\end{tabular}

After: Andrews, P.B. 1982: Revised guided to recording field observations in sedimentary sequences. New Zealand Geological Survey, DSIR, Report NZGS 102

Facies codes - see Chapter 6 for more detail

MS Massive Sandstone

LS Fining up laminated sandstone

MM Massive Mudstone Mottled mudstone

IMS Finely Interbedded Mudstone and Sandstone 


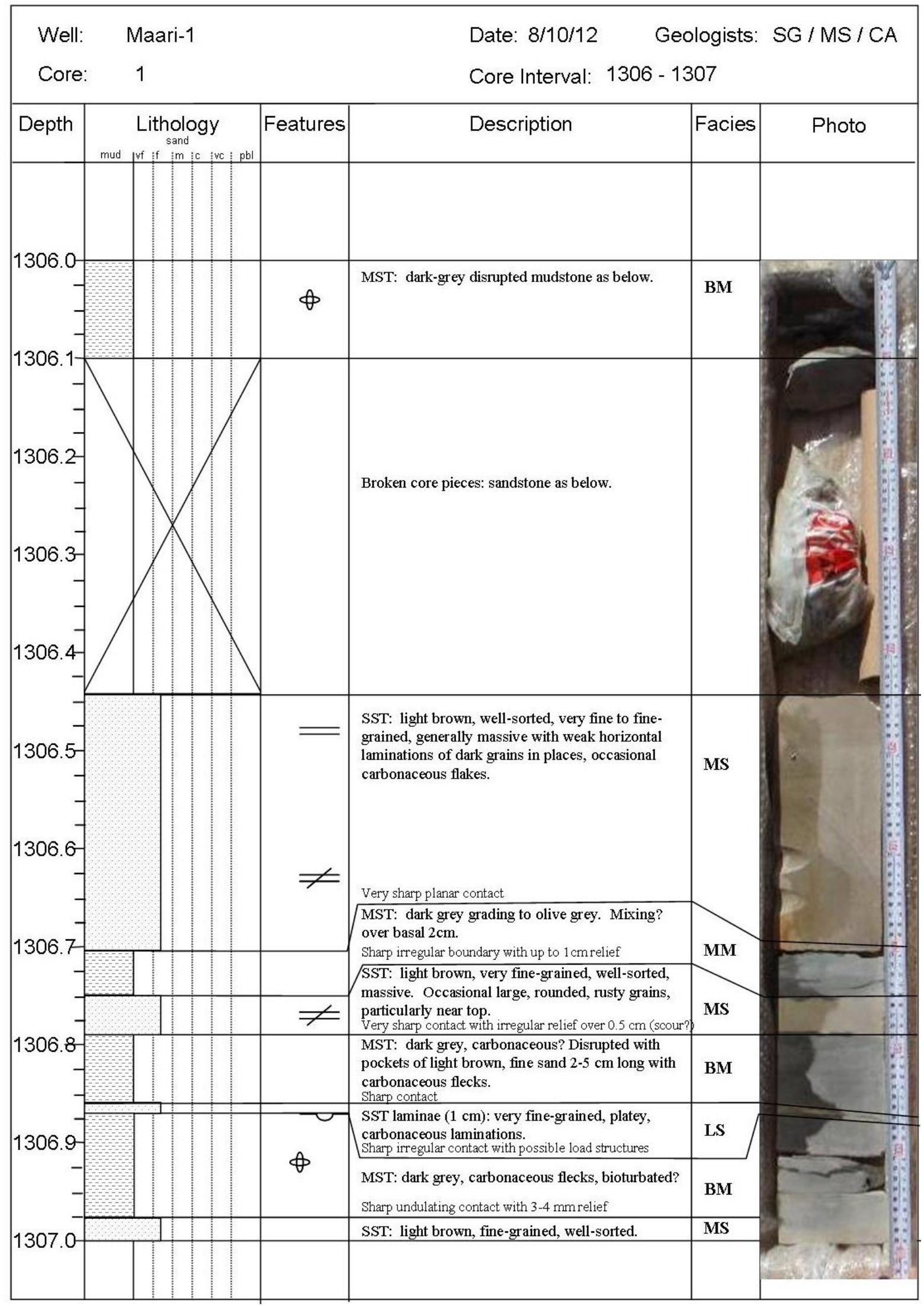




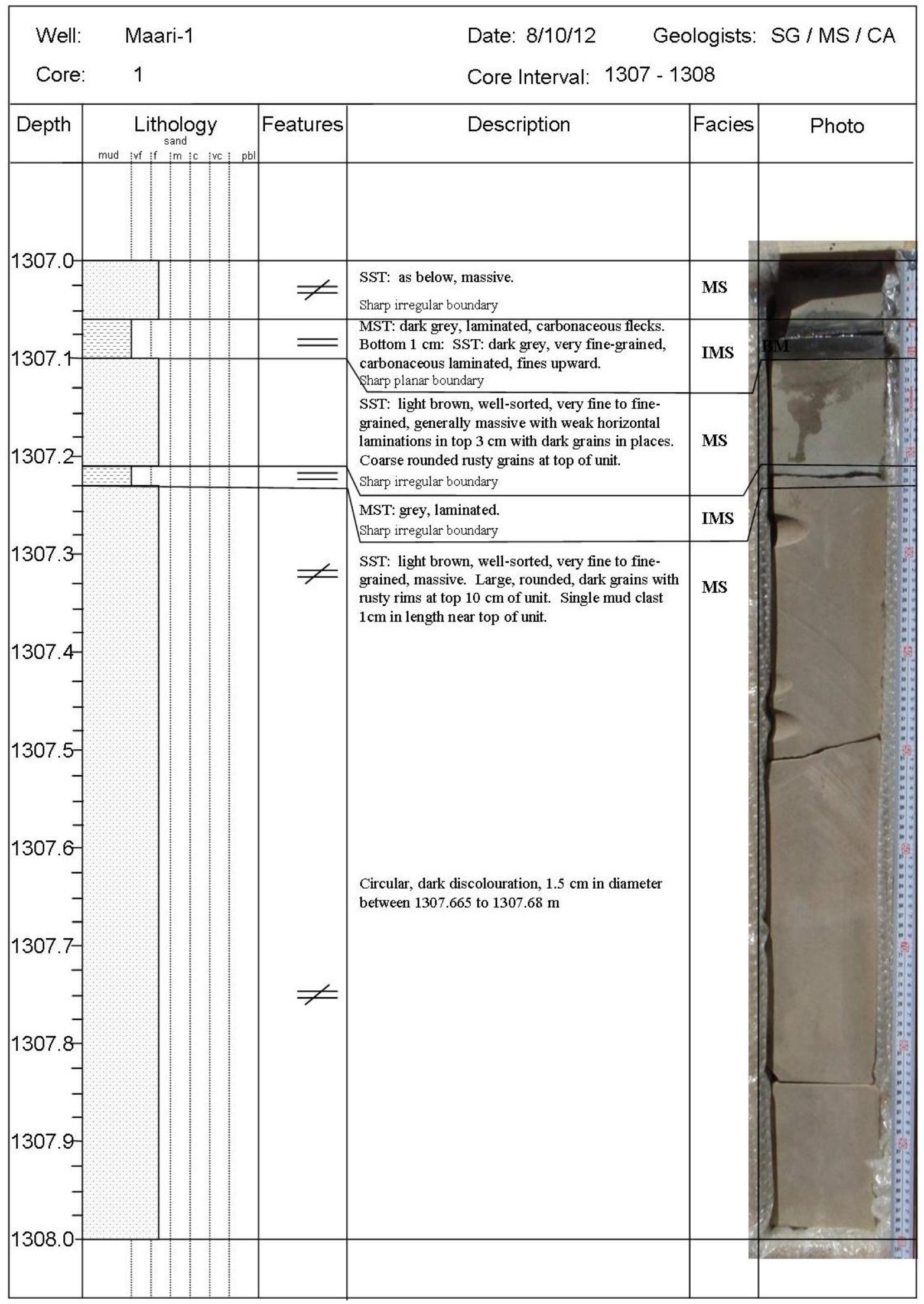




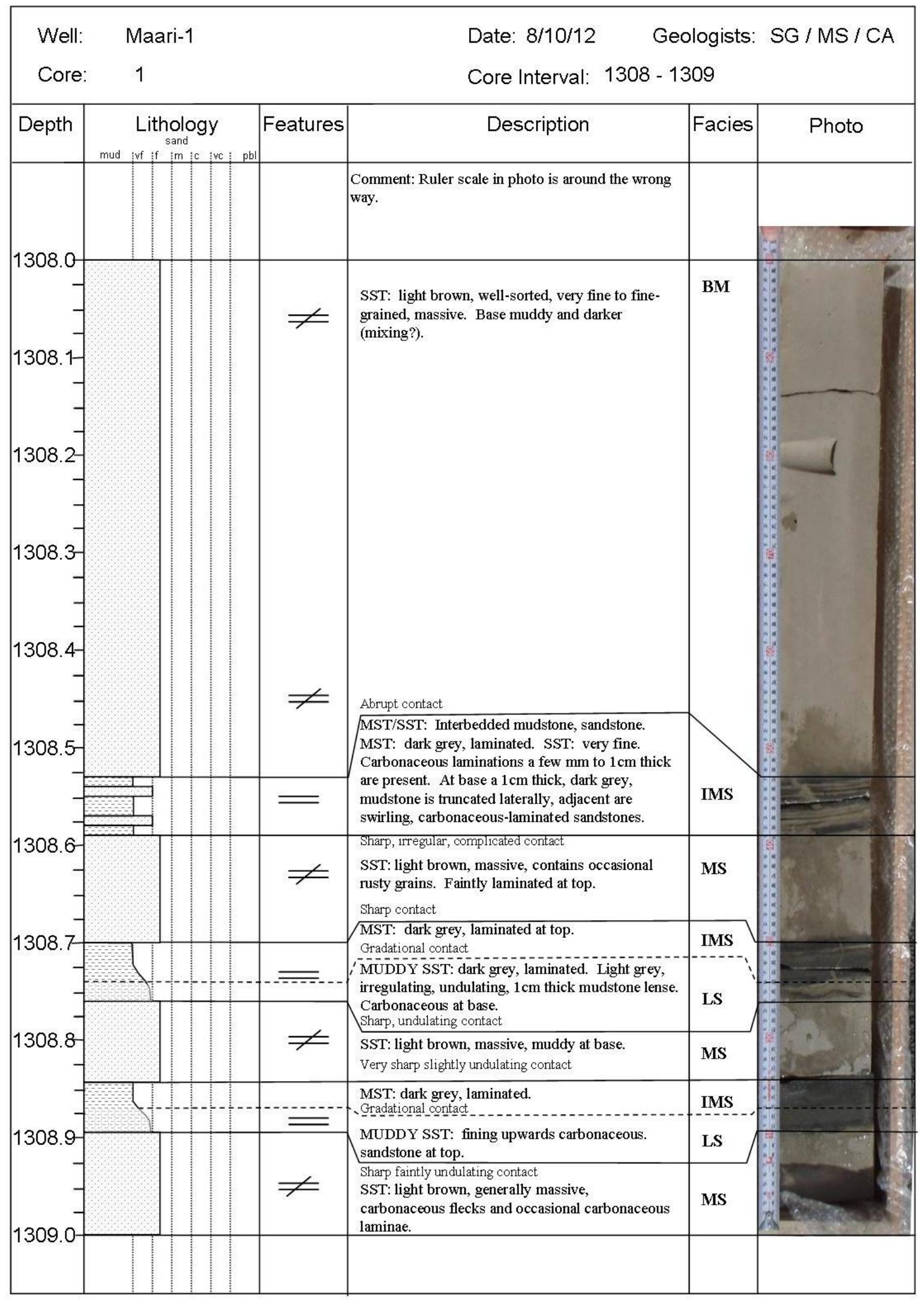




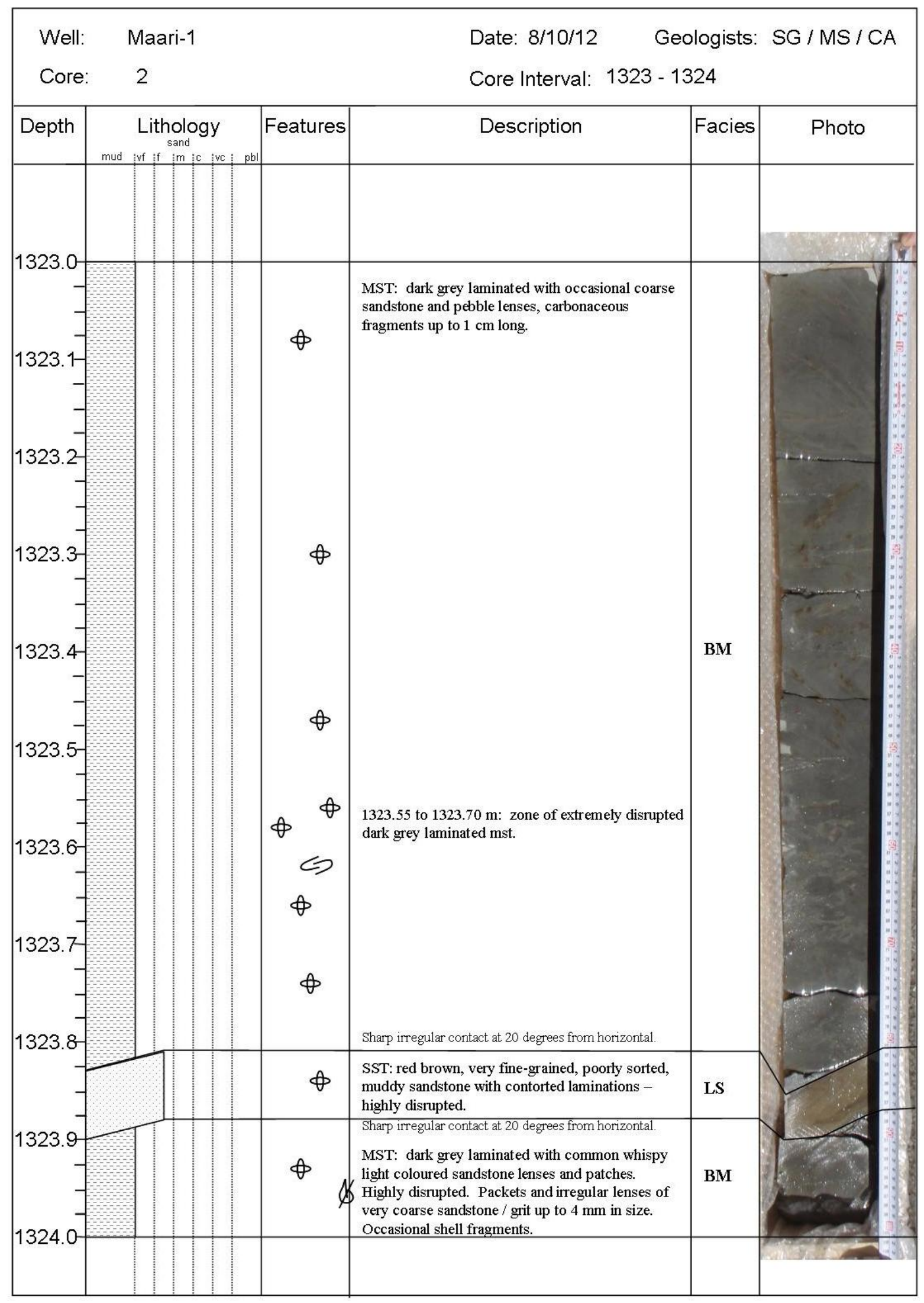




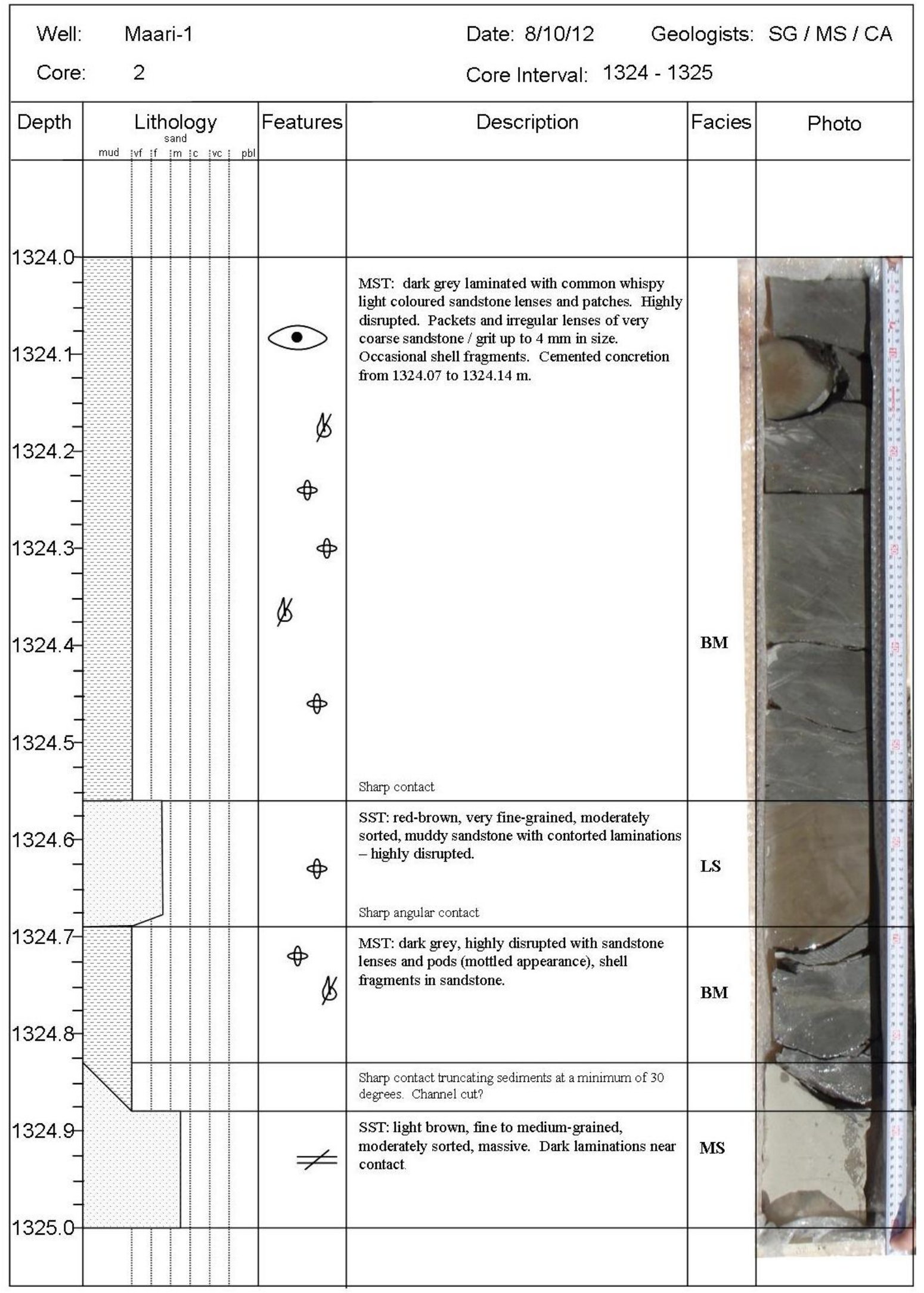




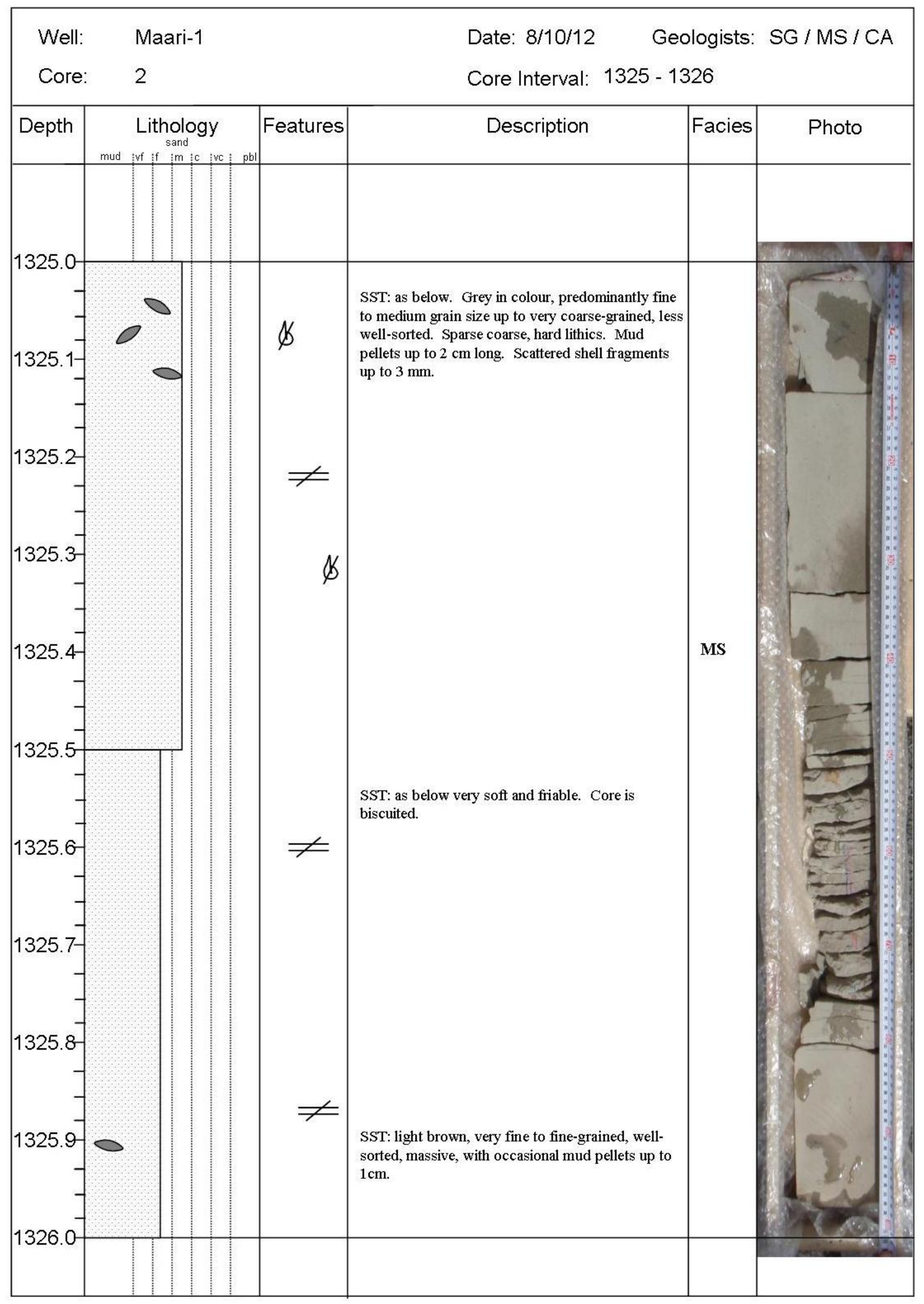




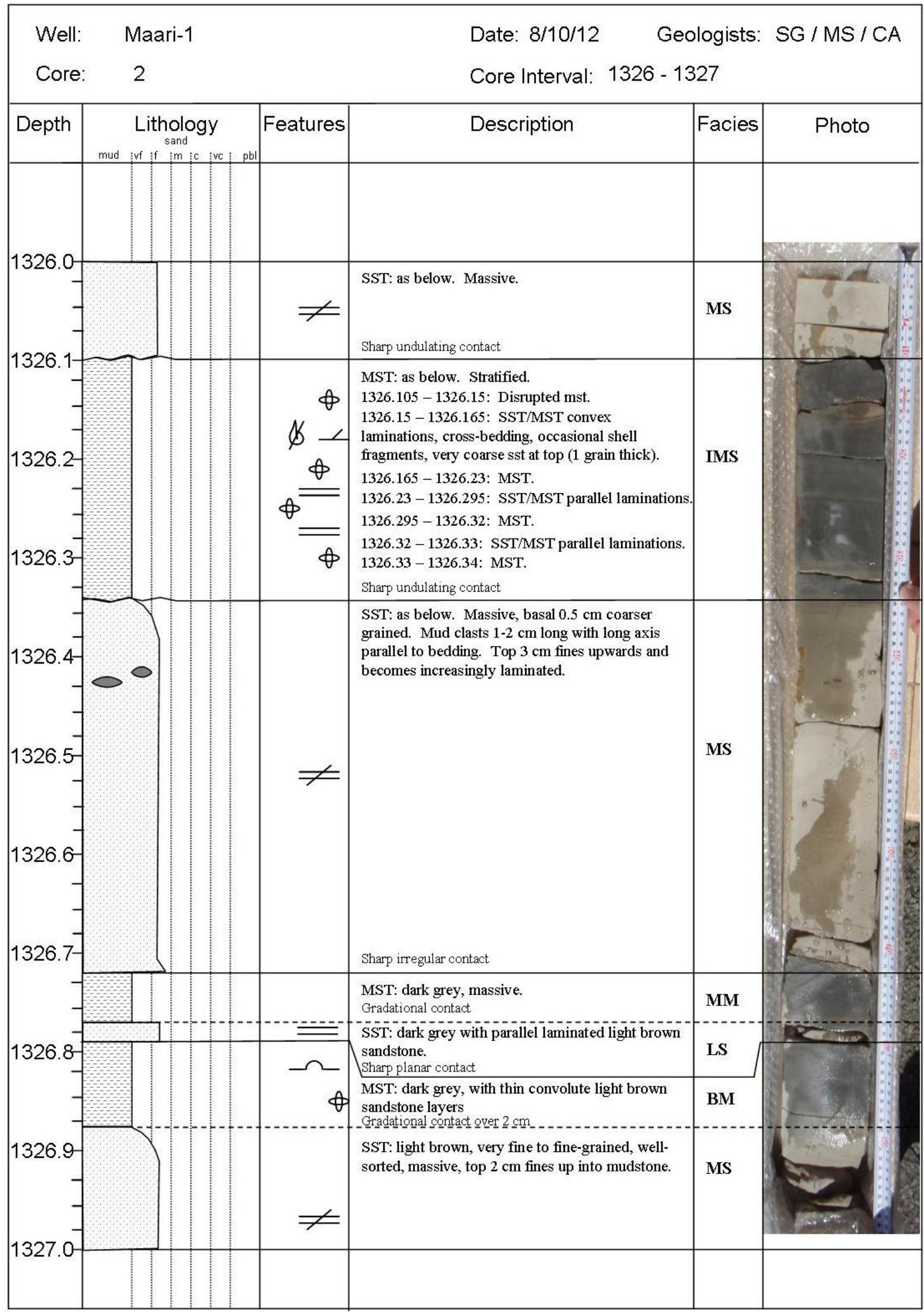




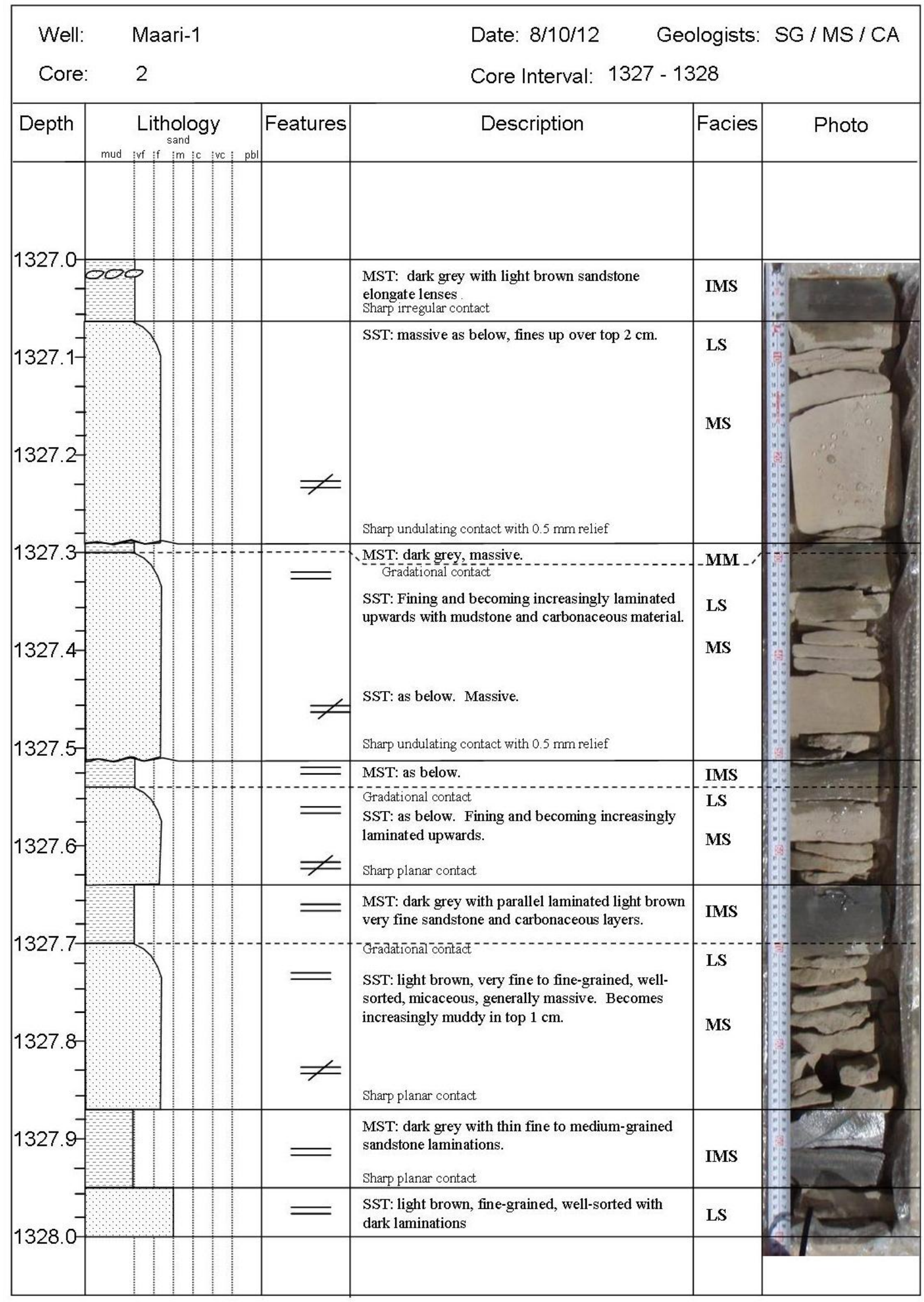




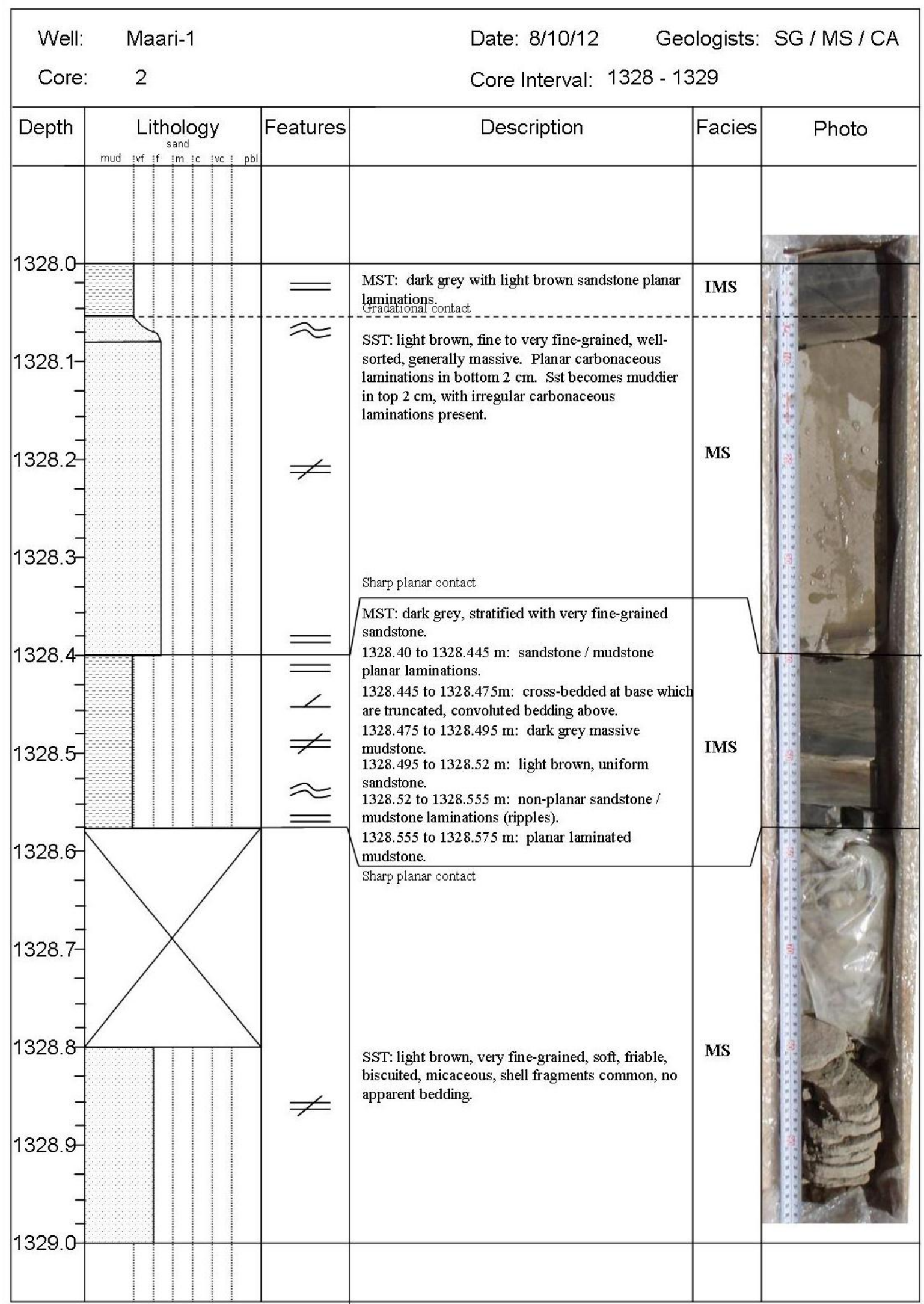




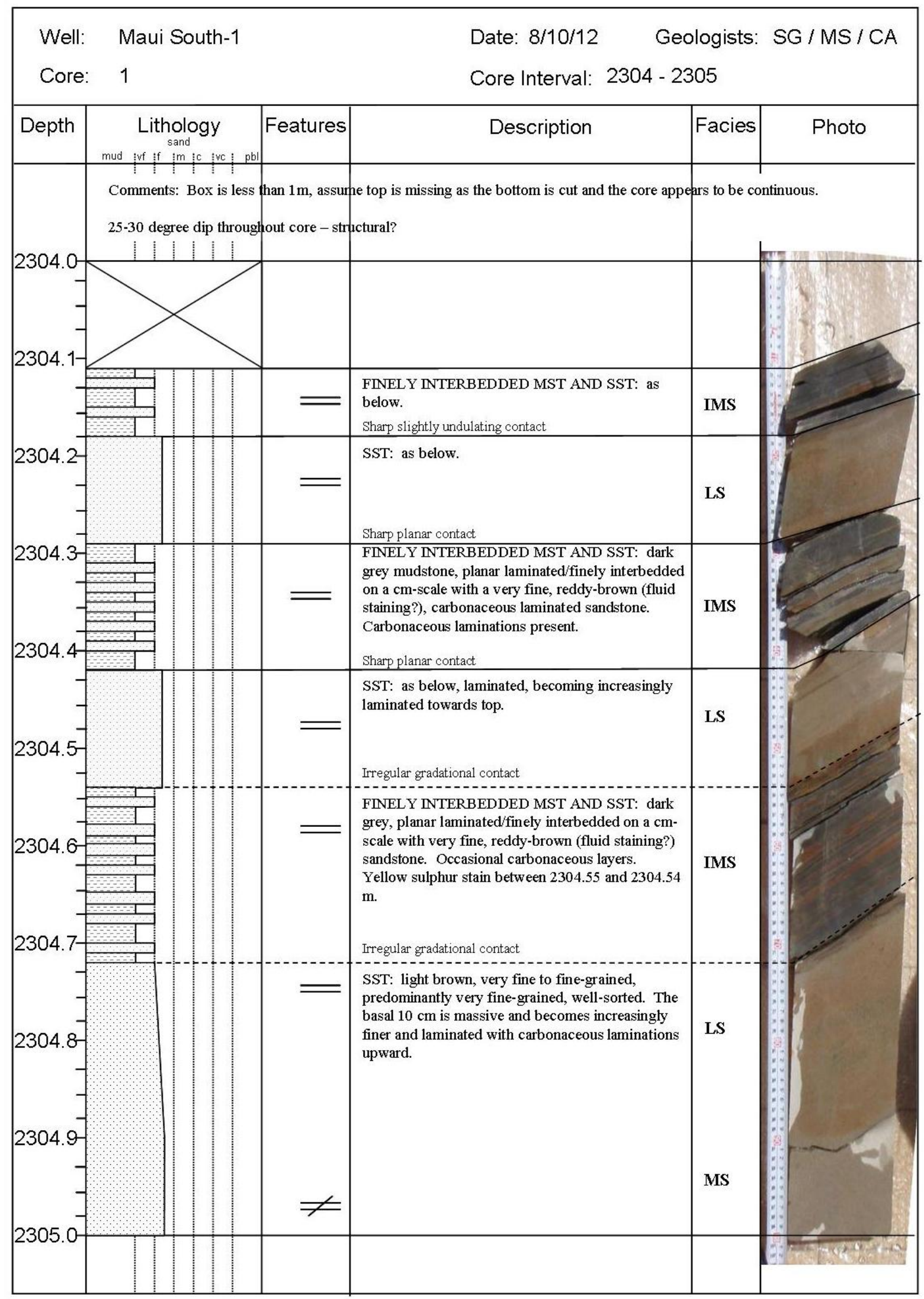




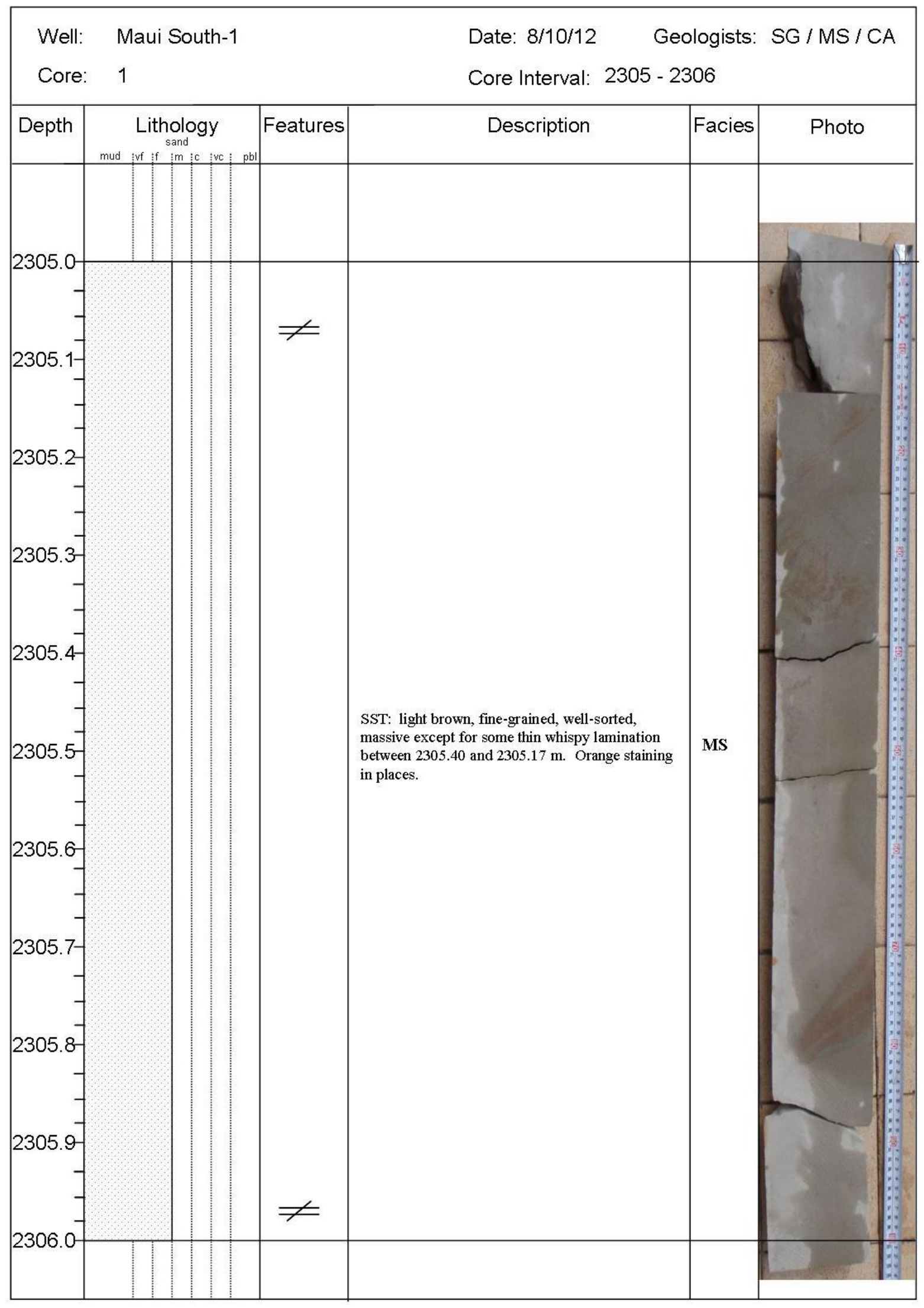




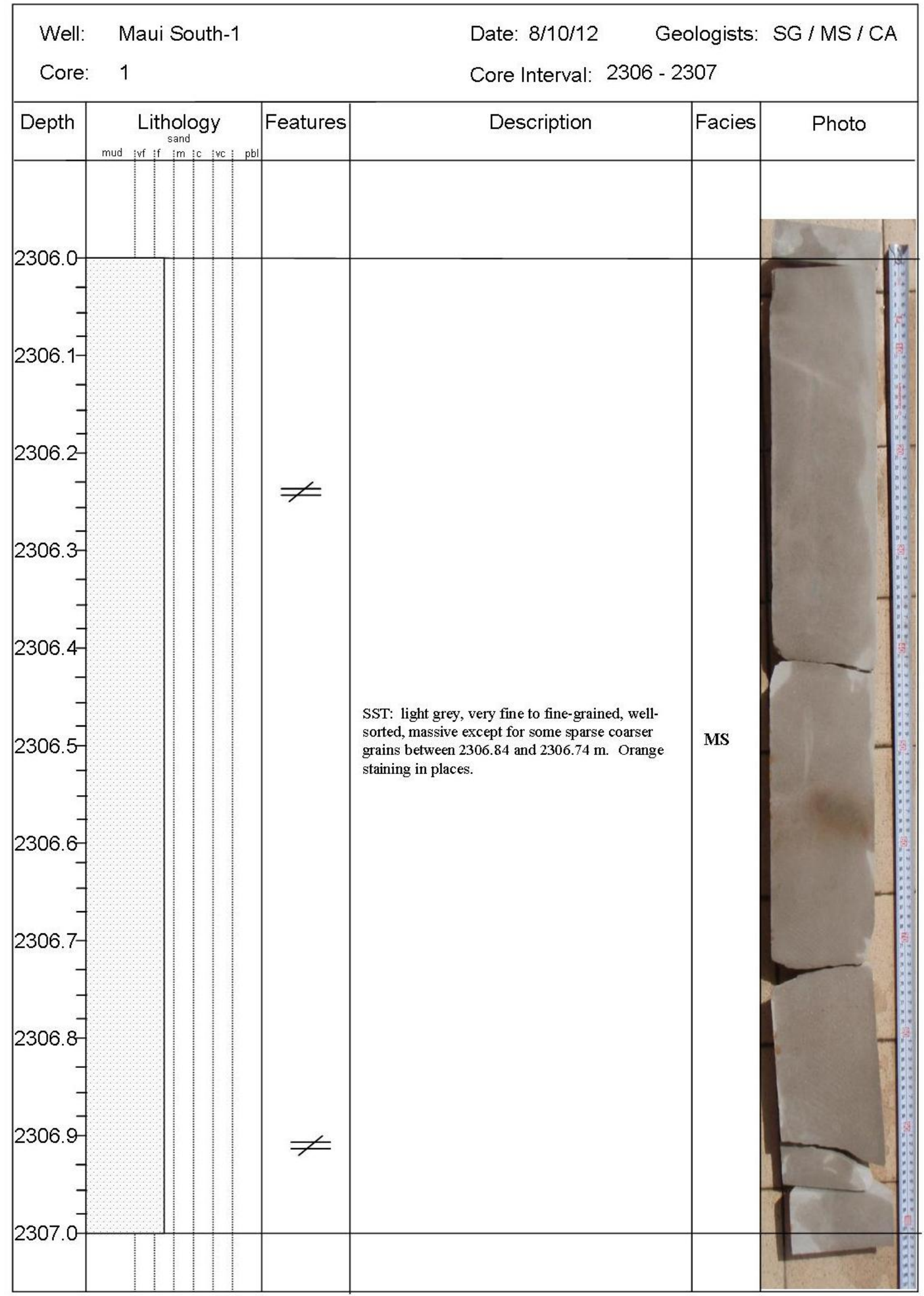




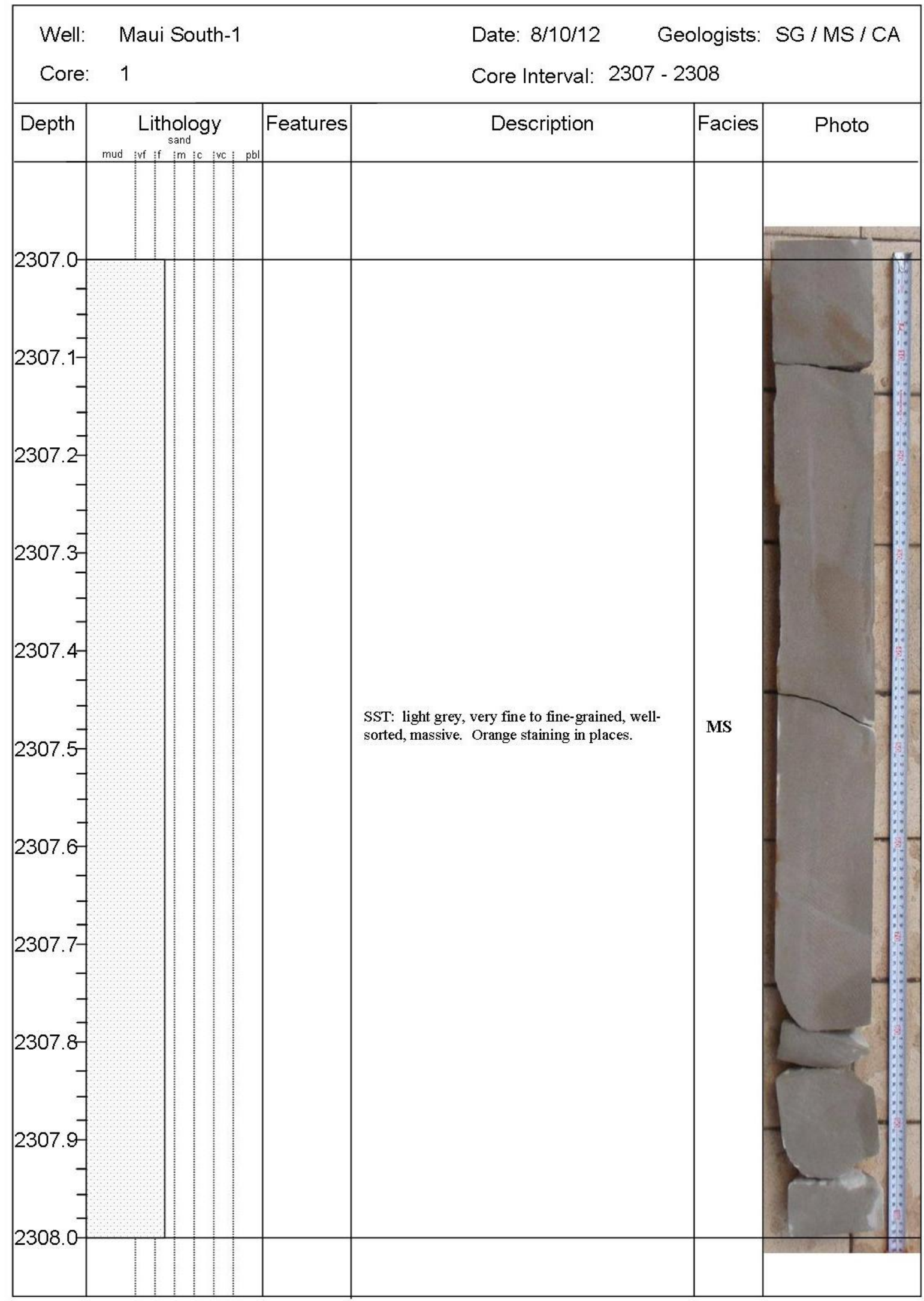




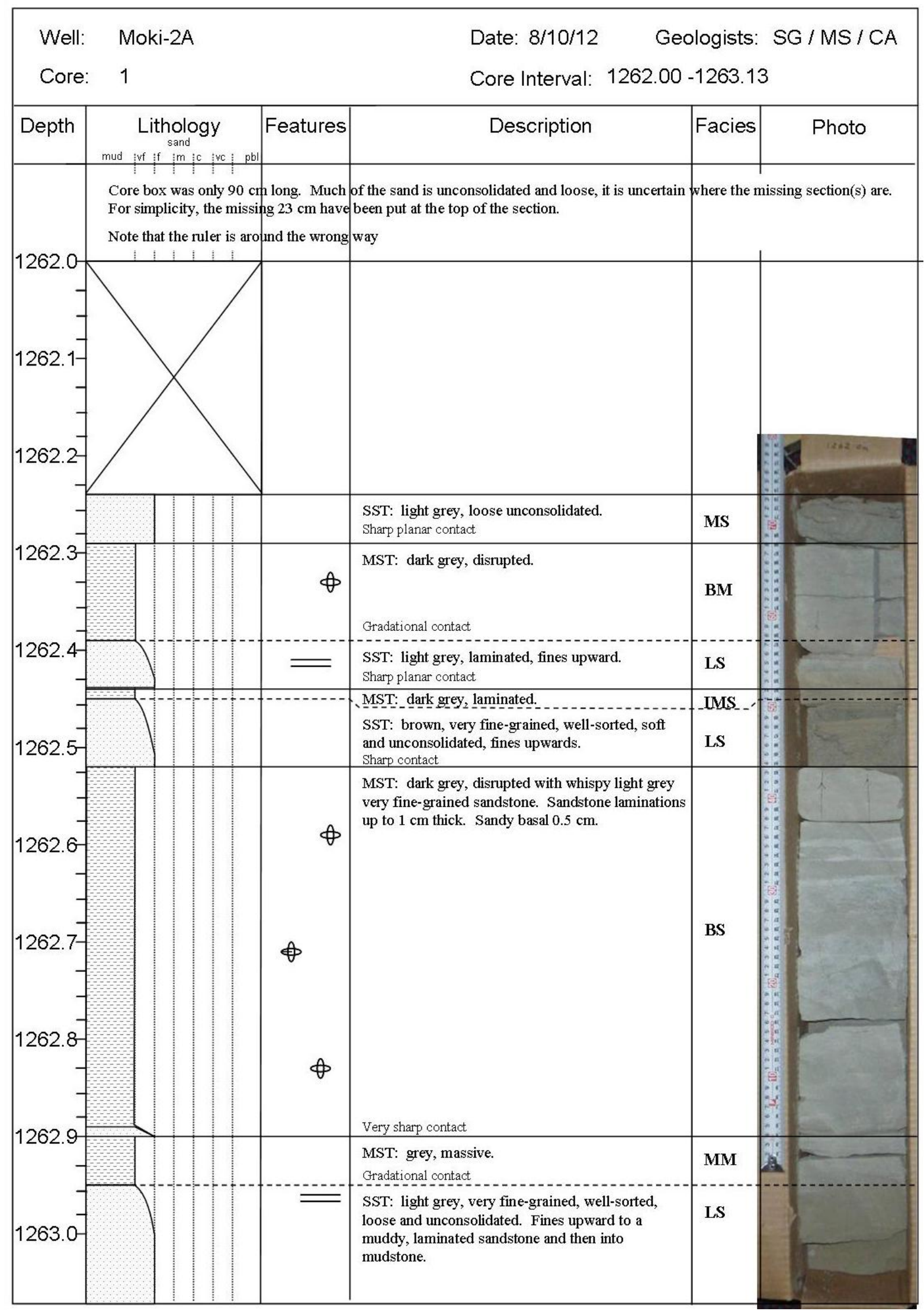




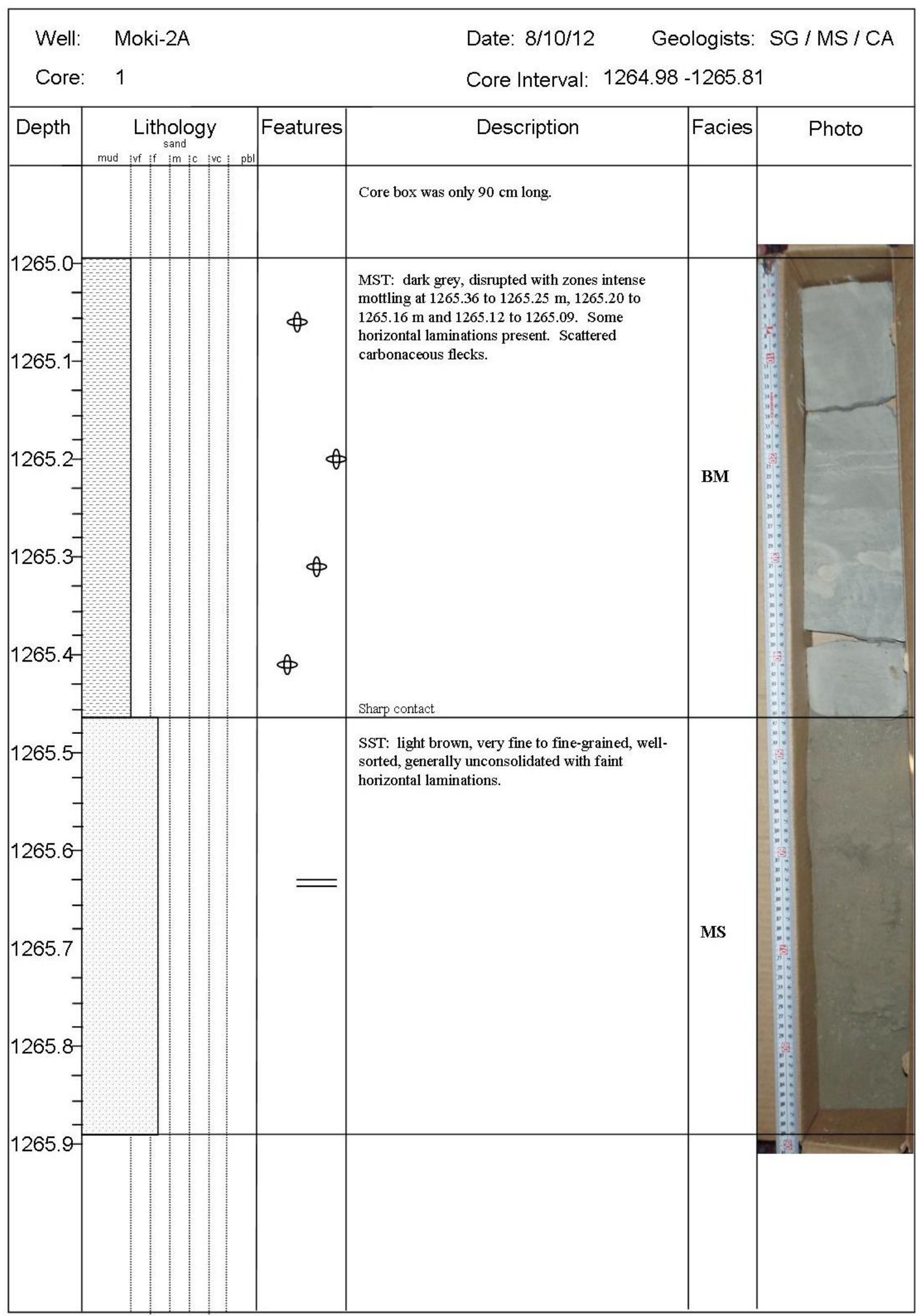




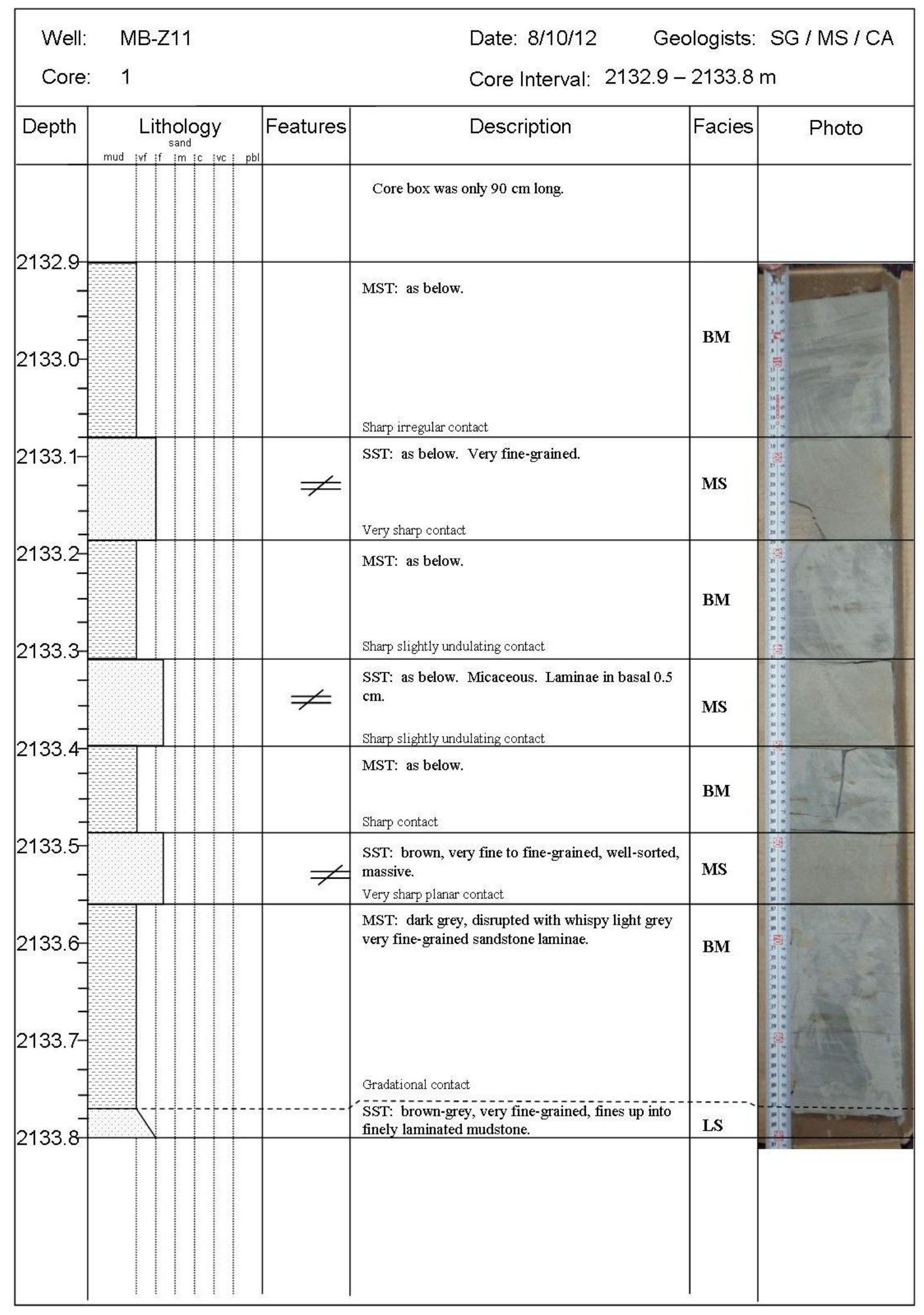

